Universidad Nacional de La Plata

Facultad de Humanidades y Ciencias de la Educación

Doctorado en Ciencias Sociales

\title{
Representaciones de la alteridad social en el ensayo indigenista peruano (1924-1930)
}

Mg. Martín Castilla

Directora: Dra. Alejandra Mailhe

Fecha de entrega: 12 de febrero de 2021 


\section{A Emilia}




\section{Agradecimientos}

A Alejandra Mailhe, directora de esta tesis, por acompañarme con calidez y generosidad durante todo el trayecto de mi formación de posgrado. Su conocimiento y dedicación, sus lecturas, los diálogos entablados, fueron indispensables para la concreción de este trabajo.

A la Facultad de Humanidades y Ciencias de la Educación de la Universidad Nacional de La Plata donde empecé a comprender lo social y a creer en lo colectivo. Al Doctorado en Ciencias Sociales -a sus docentes y a su coordinador, Martín Retamozo-, que me permitieron profundizar esos conocimientos y esas convicciones.

A CONICET, cuya beca de posgrado sustentó económicamente esta investigación. Al IdIHCS y el CTCL, ámbitos en los cuales el encuentro con otros/as investigadores/as -en el marco de proyectos PIP y PICT- estimuló la reflexión permanente sobre los temas de esta tesis.

A la cátedra de Historia de las Ideas de la cual formo parte y a quienes a lo largo del tiempo compartieron, como alumnos/as, adscriptos/as y/o participantes, ese ámbito de enseñanza y aprendizaje de historia intelectual latinoamericana, en particular a Emilio Binaghi, con quien he coordinado varios encuentros y jornadas.

A los/las amigos/as que me dio la academia, con quienes compartí el grado, la maestría y/o el doctorado, y que me alentaron afectuosamente en esta instancia final: Ornela Boix, Nicolás Welschinger, Andrés Stefoni, Nicolas Herrera, Alcira Martínez, Federico Rodrigo, Soledad López y Soledad Balerdi. 


\section{Índice general}

I. Concepciones de la alteridad social en Perú a principios del siglo XX: los intelectuales ante una sociedad que se transforma

Racismo y racialismo

El racialismo en Perú a comienzos del siglo XX

La "generación arielista" del 900: entre la estigmatización racialista y el

borramiento culturalista del "otro"

De la República aristocrática al Oncenio de Leguía: apogeo y crisis de la hegemonía oligárquica

Hacia la conformación de una tradición intelectual crítica: los aportes de Manuel

González Prada.

Cambio en el clima de ideas, surgimiento de una nueva intelectualidad y

conformación de un frente antioligárquico en los años veinte

\section{Representaciones de lo indígena en Tempestad en los Andes}

Un manifiesto indigenista

Mediaciones intelectuales

Racialismo, telurismo

Detrás de las montañas: el indígena del ayllu

El "resurgimiento" indígena en la sociedad nacional: violencia como respuesta a la opresión

El "nuevo indio": un modelo burgués para la modernización indígena

Representaciones del mestizo y del mestizaje...

El retorno de la peligrosidad indígena: ceder algo para no perderlo todo

Un problema "a medida" para los intelectuales cusqueños

La apelación al "inkario": formación de una alta cultura nacional de base incaica...

Contra Leguía: entre la política tradicional-reformista y la nueva generación

III. Raza, indianidad y mestizaje en El nuevo indio

¿Un indigenismo afin al mestizaje?

Del racialismo al culturalismo

La concepción del mestizaje en "El nuevo indio"

El espacio geográfico como reservorio de la nacionalidad

Los ideales

La mentalidad popular indiana y los "grandes hombres" 
De la religión a la política

Dinámica de la dominación cultural

Diagnóstico intelectual: el mestizaje en peligro

La amenaza de la tradición indígena.

La formación de una cultura nacional mestiza: de la política a una cultura artística de base folclorica....

Intelectuales indigenistas/ intelectuales regionalistas

Conclusiones

Disputas y debates al interior de la elite de Cusco: confrontando "por fuera de la política"

IV. El discurso indigenista en el Estado:

Castro Pozo y Nuestra comunidad indígena

El ensayo

Los indigenas en el trabajo comunitario o "minga"

La lente y el escalpelo en el viaje hacia el otro

Cortar, seleccionar, depurar e integrar: las industrias artesanales comunitarias y el folclore nacional

Proyecto educativo y dinámica del mestizaje: ideales de progreso y eugenesia culturalista....

V. Los Siete ensayos de interpretación de la realidad peruana de Mariátegui como apuesta social a fines de los años veinte

El ensayo

El indígena del pasado. Armonía y linaje civilizatorio

El indígena del presente: la ética comunitaria indígena y el espíritu del socialismo...

El indigena revolucionario: una nota al pie.

Coordenadas epistemológicas de las representaciones: el materialismo como límite al racialismo

El "alma indígena": efectos de una lente distante

Mestizos, mestizaje: recaídas en el racialismo y funciones ideológicas de la "literatura

nacional"

Arielismo y marxismo

Mariátegui: representación, práctica, apropiación como incentivo de la radicalización

Tempestad en los Andes: la fe y los mitos de la revolución socialista indígena.

VI. Proximidades y diferencias en los discursos: cuatro modulaciones alternativas del indigenismo peruano

Bibliografía 


\section{Introducción}

En la América Latina de los años veinte, surgen diversos grupos de intelectuales que, desde las periferias del campo intelectual y el campo de poder, reformulan las concepciones de la alteridad social y su gravitación en la configuración de la identidad nacional, desplegando una emergente voluntad de inclusión que desafía, desde el campo intelectual, la hegemonía de los órdenes oligárquicos. Como parte de este proceso, se observa en el ensayo de interpretación nacional una progresiva ruptura con el paradigma racialista, en favor de nuevas perspectivas epistemológicas de abordaje de las alteridades sociales (Hale, 1991), que tienden a su relegitimación. Esto ocurre en los países con gran proporción tanto de ascendencia africana como indígena, con diferencias históricas y políticas, que van desde la perduración del régimen oligárquico hasta la experiencia de la Revolución en México.

Especialmente en los países con predominio étnico indígena surgen algunas formaciones intelectuales que revisan la gravitación de los sectores populares de base indígena y colonial (y sus culturas), y que construyen representaciones de la alteridad contrapuestas a las de los intelectuales orgánicos de la dominación oligárquica, para postularlas como base de la reconfiguración de la nación (Fell, 1994; Funes, 2006, y Hale, 1991, entre otros). Esa lucha representacional sustenta, al mismo tiempo, estrategias de autolegitimación y reposicionamiento de los intelectuales, especialmente de quienes se proponen como mediadores entre la nación y su "verdadero" fundamento.

En Perú, el indigenismo emergente reúne a un conjunto de intelectuales con diferentes posiciones teórico-políticas, influenciados por la prédica de Manuel González Prada, quien tempranamente lleva a cabo una ruptura con el racialismo (Fell, 1994; Hale, 1991; Klarén, 1991 y 2004, y Quijano, 1978). Este cambio de paradigma se suma al efecto de "crisis del orden", generado por acontecimientos sociopolíticos importantes como las revoluciones mexicana y rusa, y por el despliegue de nuevas corrientes de ideas, como el relativismo 
spengleriano de posguerra y las experiencias de las vanguardias estéticas (Funes, 2006; Beigel, 2003, y Schwartz, 2002).

Como movimiento, el indigenismo aglutina a una serie de intelectuales muy diversos desde el punto de vista de sus procedencias regionales, sus orígenes de clase, sus trayectorias y sus posiciones políticas, teóricas, ideológicas y culturales. Dichas posiciones son disímiles, cuando no antagónicas (como se puede rastrear, esparcida y fragmentariamente, a partir de Beigel, 2006; Deustua y Rénique, 1984; Favre, 1998; Funes, 2006; Marzal, 1998 y Svampa, 2016). Tal es el caso de los intelectuales indigenistas vinculados a la revista Amauta (editada entre 1926 y 1930), como José Carlos Mariátegui, Luis E. Valcárcel y José Uriel García entre otros. ${ }^{1}$ El problema del indio suscita la intersección de un conjunto heterogéneo de actores sociales; es uno de los principales terrenos discursivos en los que se desarrollan las múltiples tendencias de la "nueva generación" peruana, internamente heterogénea, fragmentaria, compleja y contradictoria. En dicho espacio conviven diferentes vertientes, que a su vez se multiplican en diversas vías alternativas frente al rumbo oligárquico de la modernización peruana (Beigel, 2003 y 2006).

Entre otras diferencias conceptuales, el “incaísmo" opera una asimilación de lo indígena a lo inca y al "inkario", que frecuentemente arqueologiza la cultura indígena y rechaza todo tipo de mestizaje o fragmentación cultural por considerarlo "impuro", retomando por momentos tópicos sobre el "hibridismo" propios del racialismo clásico (Avanza, 2005). El "serranismo" y el "andinismo" implican una reivindicación regionalista y anticentralista (o mejor "antilimeña") de las regiones serranas del interior peruano, usualmente sostenida por una matriz telúrica, que considera la "sierra" como sede de la "esencia" de la "raza india" -y por ende de la nacionalidad-, diametralmente opuesta a la "costa", que se asocia a lo hispánico y colonial (Avanza, 2005; Arguedas, 1981; Beigel, 2006; Favre, 1998; Funes, 2006; Rama, 1981 y Svampa, 2016). El "neo-indianismo" reivindica lo "indio" como una identidad mestiza, fruto de la mezcla de la esencia telúrica de los Andes con la racionalidad occidental, y al mismo tiempo, postula una solución de continuidad entre los incas y los indígenas del presente (Avanza, 2005 y Beigel, 2006). El indigenismo promovido desde el Estado, o "indigenismo oficial”, propone la integración de

\footnotetext{
${ }^{1}$ La posición de Hildebrando Castro Pozo no ha sido determinada hasta el momento con certeza, permaneciendo en gran medida inexplorada por la crítica. Profundizaremos el abordaje del intelectual en el capítulo IV de esta tesis.

2 "Inkario" es el nombre con el que Valcárcel designa el corpus de prácticas y elementos culturales que, desde su punto de vista, son representativos de la cultura incaica.
} 
las comunidades indígenas a través del cooperativismo y el contrato colectivo de trabajo, en el marco de una economía mixta; no obstante, promueve la intervención sobre los indígenas del presente para depurarlos de elementos que considera resistentes a la modernización. Finalmente, el indigenismo radical o radicalizado representa una aleación entre el socialismo marxista y el vanguardismo indigenista, combinando una lectura compleja que tiene en cuenta la fuerte imbricación entre clasicidad, etnicidad y propiedad de la tierra con diversos elementos provenientes de las diferentes vertientes mencionadas.

Frecuentemente se ha asociado -aunque de manera demasiado rígida-, a Luis E. Valcárcel con el "incaísmo" y el "andinismo", a José Uriel García con el "neo-indianismo" y en general a estos dos intelectuales cusqueños dentro del "serranismo". A Hildebrando Castro Pozo se lo puede considerar una expresión del indigenismo oficial y a José Carlos Mariátegui se lo vincula con el indigenismo radicalizado. Sin embargo, tal como intentaremos demostrar a lo largo de esta tesis, estas vertientes del indigenismo suelen aparecer tensionalmente combinadas y superpuestas en el pensamiento de estos intelectuales.

La bibliografía crítica sobre esta formación intelectual peruana suele no problematizar estas diferencias epistemológicas e ideológicas (que se suman a las divergencias de sus trayectorias intelectuales), llegando a pasarlas por alto, o incluso a atribuirles directamente una proximidad recíproca en lo epistemológico y en lo ideológico (con respecto a las formas de concebir la alteridad indígena), lo cual no se sostiene cuando se abordan los ensayos de ese grupo de intelectuales.

Frecuentemente se aproximan (y en algunos casos se homologan) todas las posiciones detrás del indigenismo radical (marxista) de José Carlos Mariátegui. Tal como veremos en esta tesis, el propio Mariátegui ha contribuido a hacer perdurar este malentendido, a través de las operaciones simbólicas que despliega con el objetivo de inventar una tradición indigenista radical, de consolidar una formación intelectual, y de traccionar el campo intelectual peruano de los años veinte hacia posiciones marxistas radicalizadas. Esta cuestión abre lateralmente una pregunta sobre el modo en que se piensan las tradiciones y las formaciones intelectuales en el continente.

En este sentido, un caso paradigmático es el de Luis Valcárcel, quizás el indigenista de más renombre en los años veinte después de Mariátegui. Desde una lectura internista y literal de su ensayo Tempestad en los Andes (que tienda a resolver sesgadamente las contradicciones, sin problematizarlas), se puede caer en el equívoco de atribuirle una ruptura epistemológica en la concepción de la alteridad social, e incluso se puede llegar a asignarle 
una posición política de filiación socialista revolucionaria, que no se sostiene cuando se analiza críticamente su discurso, atendiendo a la dimensión representacional del mismo, y rastreando la trayectoria intelectual y política de Valcárcel antes y durante los años veinte. En este sentido cabe mencionar, entre otros posibles casos, el trabajo clásico de Aricó (1980: L-LI) que, parafraseando a Mariátegui, asocia el "Grupo Resurgimiento" (en el que confluyen los intelectuales cusqueños aquí abordados) con "la conformación de una tendencia de izquierda que, colocada en la perspectiva y en las reivindicaciones de las masas indígenas, mantenía una relación de comprensión con las luchas obreras urbanas", al tiempo que le atribuye a Valcárcel un inexistente "trabajo de organización e ideologización del mundo indígena", al que le suma la producción de mitos revolucionarios. En la década de 1990, Marzal (1998: 443-448), a pesar de señalar límites y cierta tendencia al "moralismo reformista", no duda en etiquetar el pensamiento de Valcárcel durante los años veinte como "indigenista radical", retomando nuevamente la idea mariateguiana de que el intelectual cusqueño busca contribuir a generar mitos movilizadores para la revolución indígena. Otras tesis más actuales recaen en las mismas lecturas.

¿Pero cómo dar cuenta de las diferencias epistemológicas, políticas e ideológicas que separan los indigenismos de Valcárcel y García? En todo el indigenismo peruano -y aún dentro del indigenismo vinculado a Amauta-, las divergencias entre las posiciones se encuentran plasmadas en los ensayos de los intelectuales señalados, siendo las concepciones de la alteridad indígena allí presentes un artefacto cultural privilegiado para descifrar las posiciones teóricas y políticas de los intelectuales indigenistas que, en los años veinte, cuestionan el rumbo oligárquico de la modernización peruana, y que consideran que toda reformulación de la nación debe, de un modo u otro, incluir al indígena y/o su tradición cultural, hasta entonces excluidos material y simbólicamente. Dichas representaciones, que condensan las huellas epistemológicas, políticas e ideológicas de su producción, operan como mediaciones (en el sentido de Angenot, 2010, y de Williams, 1980) hacia los diferentes proyectos que conviven en tensión, en el interior del campo intelectual y de la propia formación intelectual indigenista, en pugna por la hegemonía. El hecho de representar sujetos indígenas más o menos refractarios a la modernidad, dóciles o peligrosos, aptos o no para el trabajo, autónomos o heterónomos, tiene su correlato en diferentes proyectos, en un arco que va desde la eliminación física, pasando por la eugenesia, el mestizaje cultural, la inclusión subalternizada, el paternalismo, la emancipación étnica y de clase, etc. En este sentido, coincidimos con De la Cadena (2007) y Wade (2000), entre otros, en que las categorías epistemológicas y las representaciones sociales a partir de las que se intenta aprehender al 
"otro" en América Latina son construcciones sociales (contextuales, situacionales, multívocas) históricamente variables, inmersas en (y a la vez, configurativas de) relaciones específicas de poder, que siempre conllevan una carga política y que tienen consecuencias en el establecimiento de fronteras, jerarquías, inclusiones y exclusiones sociales.

En la dimensión representacional, suelen activarse ideologemas residuales, todavía activos, que conducen - directa o indirectamente- a la inferiorización de los subalternos, y que contradicen otras áreas más controladas de esos mismos discursos. Esas formas de abordar la alteridad social dicen mucho más acerca de los intelectuales que de su objeto de análisis, ya que el modo en que se construyen esas representaciones habilita y legitima la postulación de la necesidad de la intervención letrada.

Indagar esas representaciones nos permite, entonces, recuperar la configuración imaginaria del "nosotros" desde donde enuncian e intervienen estos intelectuales en el Perú de los años veinte, sus concepciones normativas del intelectual y su rol en la sociedad (De Certeau, 1999). ${ }^{3}$

Los críticos que no caen en esa homogeneización del objeto, han abordado sólo fragmentariamente el discurso de los indigenistas peruanos de los años veinte nucleados en torno a la revista Amauta. Frecuentemente la deslumbrante figura de Mariátegui ha sido el centro de atención, soslayando el análisis de otros intelectuales como Luis E. Valcárcel, José Uriel García e Hildebrando Castro Pozo (que han quedado en muchas dimensiones inexplorados), así como tampoco se han considerado las vinculaciones teóricas e ideológicas de sus discursos entre sí (en términos de proximidad, distancia y tensiones, concepción sobre

\footnotetext{
${ }^{3}$ La paradoja que señala De Certeau es que, marcada por la relación con el poder disciplinador desplegado en torno a la constitución de los estados-nación, la búsqueda científica de lo popular repite siempre un gesto represivo -la eliminación de una amenaza popular-, solidario con el ordenamiento político racionalizador, homogeneizante, propio de los dispositivos disciplinarios de la modernidad capitalista (y también, de proyectos modernizadores alternativos como el soviético), inclusive aún cuando se propone manifiestamente una reivindicación de lo popular, un rescate, o una ruptura de la jerarquía implicada en la relación investigador/investigado. Esto significa que aún las posturas "populistas", que idealizan las culturas populares, están autorizadas por el poder, visible en la legitimidad vinculada a la dotación de recursos simbólicos que tienen los letrados, desigual, asimétrica frente a la cultura popular que no tiene recursos para articular una voz legítima, y que es, por definición, afásica. Asimismo, De Certeau dice que la "cultura popular" está siempre mediada por los intelectuales (afirmación que, consideramos, se puede hacer extensiva a los abordajes de la alteridad social). Siempre aparece re-presentada, esto es, vuelta a presentar por el discurso de los letrados, que inevitablemente operan un filtro, una violencia sobre el objeto de representación, cuya multiplicidad de sentidos desborda ampliamente los límites de los significantes construidos por los letrados. Toda representación presupone mecanismos sociales de elección, de crítica, de organización, en fin, de recorte del objeto empírico. Implica siempre también un lugar de enunciación, con condiciones de producción. Es por ello que De Certeau considera que las definiciones de la cultura popular y de los sujetos populares -el "otro" del letrado que enuncia- dicen más del intelectual que del objeto que pretenden definir. Las representaciones, marcadas por esa violencia de origen, llevan también siempre las huellas epistemológicas, políticas e ideológicas de su producción por parte de un letrado. Del mismo modo, lo que se excluye en esas representaciones señala, en negro sobre blanco, posicionamientos intelectuales (De Certeau, 1999: 69-70).
} 
el rol del intelectual y sus relaciones con lo popular), ni las relaciones específicas de sociabilidad intelectual que establecen los indigenistas entre sí. ${ }^{4}$

En consecuencia, resulta necesario realizar un análisis comparativo de las perspectivas indigenistas más citadas en los Siete ensayos de interpretación de la realidad peruana (las de Valcárcel, García y Castro Pozo), trabajo aún no realizado de un modo profundo y sistemático por la crítica, que permita partir de una base sólida para establecer luego una relación comparativa con respecto al indigenismo de Mariátegui. ${ }^{5}$

Comencemos por señalar algunos trabajos que han iluminado diferentes dimensiones del fenómeno del indigenismo peruano de los años veinte, y que al tocar de un modo más o menos directo el problema planteado, delinean un horizonte de debates que debe ser considerado como punto de partida para esta investigación.

Una descripción del contexto social, político y cultural de los años veinte y treinta en Perú, concebido como momento de crisis de la hegemonía oligárquica, es llevada a cabo por Quijano (1978), Hale (1991), Klarén (2004) y Funes (2006). Contamos con un abordaje del estado del campo intelectual en el período, el clima de ideas, los debates y problemas que dominan la agenda intelectual, gracias al trabajo de Deustua y Rénique (1984), y a algunos fragmentos de las investigaciones de Beigel (2003 y 2006), Bergel (2010), Funes (2006) y Svampa (2016). Sobre la tradición de pensamiento previa, englobada bajo el rótulo de “generación del novecientos” o "generación arielista", han trabajado Osmar Gonzáles (1996) y Gil Lázaro (1994), esta última centrándose en la figura de Francisco García Calderón. El pasaje del racialismo, como elemento epistemológico predominante en el discurso intelectual, hacia nuevos planteamientos rupturistas, atendiendo particularmente a la emergencia del indigenismo, está presente en los trabajos de Hale (1991), Ansaldi y Funes (2003), Fell (1994), Funes (2006) y Lagos (2010).

Los estudios de Avanza (2005), Beigel (2003 y 2006), Deustua y Rénique (1984), Favre (1998), Fell (1994), Funes (2006), Marzal (1998) y Svampa (2016), entre otros,

\footnotetext{
${ }^{4}$ Por ejemplo, prácticas editorialistas (Avanza, 2005; Beigel, 2006, y Zeballos Aguilar, 2002) y epistolares (Tarcus, 2001).

${ }^{5}$ Deborah Poole realizó una breve comparación entre los regímenes de visibilidad de lo popular en los discursos indigenistas cusqueños de Valcárcel y Uriel García, en su libro Visión, raza y modernidad (2000).
} 
permiten realizar una primera aproximación (aunque en la mayoría de los casos, fragmentaria y provisoria, debido al carácter panorámico y diacrónico de los abordajes) a las diferentes modulaciones del discurso indigenista en los años veinte, identificando algunos de los principios ideológicos y epistemológicos que sustentan esa diversidad de posiciones, entre los que se destaca el regionalismo al que adscriben muchos de esos intelectuales.

Algunos análisis que insinúan una mirada relacional y al mismo tiempo comparativa, aunque -como hemos señalado más arriba - tendiendo a operar un sesgo homogeneizante sobre las perspectivas de los intelectuales indigenistas, son los realizados por Marzal (1998), Funes (2006) y Svampa (2016).

Los dispositivos y las prácticas intelectuales que vehiculizan estos diferentes proyectos indigenistas (las revistas, los emprendimientos editoriales, junto con las prácticas de sociabilidad y las redes intelectuales) pueden estudiarse en los trabajos de Beigel (2006), Tarcus (2007), Terán (2008) y Zeballos Aguilar (2002), entre otros.

Para un abordaje general de la figura, la trayectoria y el discurso de Mariátegui, más allá de su discurso en los Siete ensayos... -en particular el análisis de la combinación de indigenismo y marxismo en su pensamiento-, pueden consultarse los textos de Aricó (1980), Beigel (2003 y 2007), Kohan (2000), Lagos (2010), Lauer (1998), Paris (1980), Quijano (1988), Terán (1986), Sazbón (2002), Schwartz (2002), entre los más destacados

El objetivo general de esta tesis será abordar los ensayos Tempestad en los Andes (1927) de Luis Valcárcel, El nuevo indio (1930) de José Uriel García, Nuestra comunidad indígena (1924) de Hildebrando Castro Pozo y Siete ensayos de interpretación de la realidad peruana (1928) de José Carlos Mariátegui, para analizar las concepciones de la alteridad social indígena que construyen estos intelectuales, atendiendo tanto a las marcas epistemológicas, políticas e ideológicas de su producción que permitan dar cuenta de las posiciones específicas desde las que se enuncian esas representaciones, como así también al funcionamiento de sus textos como "mediaciones" con respecto a diferentes proyectos -esbozados por estos intelectuales- de reconfiguración de la nación peruana.

Junto con ese abordaje diacrónico (que abarca un período neto de cuatro años si consideramos que el texto de García fue escrito en 1928, aunque su publicación se demoró dos años), nos proponemos determinar, a partir del análisis sociológico de las concepciones 
de la alteridad social, la presencia de significados, valores y prácticas hegemónicas, así como también de elementos "dominantes", "residuales" y "emergentes" (Angenot, 2010 y Williams, 1980) en las dimensiones epistemológica, política e ideológica de esas discursividades, comparando a los autores del veinte seleccionados entre sí, pero también contrastándolos diacrónicamente con respecto a la tradición representacional previa.

Complementariamente, procederemos a reconstruir algunos aspectos de las trayectorias, la sociabilidad, las prácticas y las estrategias referidas al campo intelectual, desplegadas por estas figuras, para articularlas con su producción discursiva. En esta dirección, atenderemos a sus itinerarios sociales, políticos, profesionales e institucionales; a las prácticas intelectuales específicas de representación, resignificación y apropiación; a sus vínculos y al establecimiento de redes y ámbitos de sociabilidad intelectual, e incluso a las estrategias de autolegitimación y de reposicionamiento en el campo intelectual y/o de poder.

En ese sentido, la propuesta metodológica del trabajo es combinar la perspectiva de la historia intelectual (redefinida a partir de herramientas teórico-metodológicas provistas por la sociología de la cultura) con la sociología de los intelectuales. En esta dirección, se priorizará el análisis de los discursos y representaciones existentes en las fuentes, pero sin desatender el estudio de los itinerarios, las estrategias y las prácticas de los intelectuales en un contexto histórico y social determinado, como un acerbo auxiliar para la investigación que permita visualizar cómo intervienen estos elementos en las modulaciones de los discursos, bajo la consideración de que éstos siempre están atravesados por lo social.

La perspectiva de historia intelectual a la que hacemos referencia apela a diversas teorías ligadas a la sociología de la cultura y el análisis cultural -sin excluir otros aportes-, para el reconocimiento de las operaciones ideológicas y simbólicas de la vida social, así como también para la interpretación de las significaciones de la ideología y la cultura en términos de su constitución y sus efectos.

En especial, abordamos los textos aplicando una metodología de análisis del discurso, inspirada en las propuestas de la teoría sociocrítica (en la que podemos inscribir los aportes de Foucault, 1970; Bajtín, 1992; Voloshinov y Bajtín 1992; Maingueneau, 1987; Angenot, 2010, y la semiología de la connotación de Barthes, 1999). En lo que respecta específicamente al análisis del discurso racialista, se toman los aportes de Todorov (1991), Wade (2000) y De la Cadena (2007). La obra de Chartier (1995) permitirá contar con una teoría de las prácticas representacionales $\mathrm{y}$, conjuntamente, de las apropiaciones y resignificaciones de las representaciones. 
La puesta en relación de los discursos sociales vinculados -o contrapuestos- al indigenismo peruano, y el análisis del impacto que tienen esos discursos en la producción de consenso, son realizados a partir de la teoría de la hegemonía cultural clásica de Gramsci (1972a) y de la más contemporánea de Williams (1980), como así también desde la perspectiva de la hegemonía discursiva de Angenot (2010). Simultáneamente, con Bourdieu (1988) concebimos el orden simbólico como un orden político, prestando especial atención a la dimensión simbólica de la lucha de grupos y clases. El aporte de Williams (1980) permite reconocer la coexistencia de significados, valores y prácticas "dominantes", "residuales" y “emergentes" en los discursos sociales, la constitución de nuevas "estructuras del sentir", y la importancia de las "mediaciones" en el proceso sociocultural.

La mirada de los intelectuales sobre el otro social, e incluso las paradojas y contradicciones presentes en un mismo texto, son analizadas a partir de los conceptos de etnocentrismo y relativismo cultural tal como los define y aplica Todorov (1992), para el caso de los intelectuales europeos de los siglos XIX y XX, y Wade (2000) y De la Cadena (2007) para el caso local.

Para llevar a cabo esta propuesta, apelamos al instrumental teórico y metodológico provisto, desde la tradición sociológica, por Pierre Bourdieu (2000), para el análisis de los intelectuales. Nuestro abordaje entiende entonces a los intelectuales como el conjunto de sujetos que, en las sociedades modernas, cumplen la función de producir bienes simbólicos, dada su posesión del monopolio de dicha producción. Por su particular dotación de capital cultural, ocupan un lugar ambiguo en el campo de poder: son una fracción dominada entre los dominantes, hecho que los inclina a mantener una relación ambivalente respecto tanto de las fracciones dominantes de la clase dominante, como de los sectores subalternos (posicionamiento en el que también incide la posición ocupada en el campo en que se desarrolla esa actividad específica). De ahí que otra noción fundamental que este trabajo presupone es la de campo intelectual, entendido como el espacio relativamente autónomo, regido por reglas propias, donde se desarrolla la sociabilidad y las luchas de los intelectuales. En estas luchas simbólicas, los intelectuales disputan el monopolio de la producción cultural y las representaciones sociales legítimas, a través de estrategias que se vinculan con las posiciones de cada actor en el campo (definidas a partir de la legitimidad y el reconocimiento que tengan en el propio campo y en otros sectores sociales, como posiciones centrales y periféricas).

Del mismo modo, los conceptos de "formación" -que utilizamos para definir el conjunto de intelectuales indigenistas-, "tradición selectiva" e "instituciones", tal como los 
emplea Williams (1980), nos permiten abordar dimensiones específicas de las prácticas de los intelectuales. Atendemos a los principios metodológicos planteados por Altamirano (2005) para definir la praxis de la historia intelectual, articulando el análisis de las fuentes con la consideración sobre los itinerarios sociales, políticos y profesionales de los intelectuales.

Para la conformación del corpus, hemos privilegiado a los autores que gravitan en Siete ensayos de interpretación de la realidad peruana (1928) de José Carlos Mariátegui. Por ello, partir de textos básicos como Carácter de la literatura del Perú independiente (1905) de José de la Riva Agüero y Las democracias latinas de América (1912) de Francisco García Calderón nos permitirá abordar brevemente las concepciones de la alteridad social indígena construidas por la generación arielista del novecientos, estableciendo un punto de partida para luego compararlo con las formulaciones indigenistas posteriores seleccionadas: Tempestad en los Andes (1927) de Luis Valcárcel, El nuevo indio (1930) de José Uriel García, Nuestra comunidad indígena (1924) de Hildebrando Castro Pozo, y finalmente el propio Siete ensayos de interpretación de la realidad peruana (1928) de Mariátegui, que serán a su vez contrapuestas entre sí. El primer capítulo de la tesis se destina entonces a analizar el contexto social y político del Perú desde fines del siglo XIX y la década de 1920, y a revisar brevemente las visiones de lo indígena presentes entre los arielistas peruanos y entre algunos intelectuales "marginales" de esa etapa (en el sentido de Angenot, 2010) como Manuel González Prada. 


\section{Concepciones de la alteridad social en Perú a principios del siglo XX: los intelectuales ante una sociedad que se transforma}

Hacia 1895 Perú logra insertarse establemente, aunque de manera periférica y dependiente, en la economía capitalista mundial, como proveedor de materias primas. De ese modo se ajusta a las demandas de los centros capitalistas en expansión durante la segunda revolución industrial, que requieren tanto de esos productos primarios para su producción, como de mercados para colocar sus productos y excedentes de capital; en este sentido, Perú es un terreno particularmente atractivo y vulnerable (Klarén, 1991: 246). Se inicia así un proceso de ampliación y profundización de las relaciones capitalistas en la sociedad peruana, que genera importantes cambios en todas las áreas de la experiencia social (entre otros, Deustúa y Rénique, 1984: XII). Las consecuencias de ese proceso serán un nudo fundamental de conflicto social y la reflexión intelectual sobre éste, durante las tres primeras décadas del siglo XX, y de manera más intensa entre los años 1919 y 1930.

El desarrollo del modelo agro-exportador consolida la dominación económica de una nueva fracción de la clase dominante, ligada tanto a la producción primaria como al comercio de exportación. Esta burguesía terrateniente comercial, montada en el éxito económico y las estrechas relaciones con los capitales británicos y crecientemente norteamericanos, logra por primera vez, desde la emancipación, el pleno dominio del poder político, hasta entonces en manos de los militares (Quijano, 1978: 75). Este grupo se va consolidando hasta formar una poderosa oligarquía que se organiza políticamente en el Partido Civilista (aliado con el Partido Demócrata, del caudillo Nicolás de Piérola), a través del cual logra el control del Estado hacia fines de siglo, instaurando lo que la historiografía peruana llama la "República Aristocrática", comprendida entre los años 1895 y 1919. El civilismo, cercano a las doctrinas liberales del laissez faire, encara la ampliación y centralización de la esfera estatal para adaptarse mejor a las demandas y crecientes complejidades de la economía capitalista mundial (Klarén, 1991: 233).

La oligarquía civilista genera intervenciones intelectuales, cuyo objeto de reflexión principal es la "realidad nacional", y más precisamente, el diagnóstico sobre los obstáculos que impiden la "modernización" de la nación peruana. Esa reflexión, que frecuentemente 
toma la forma de ensayo, tiene como contraparte un modelo de país, una propuesta o proyecto tendiente a superar esas trabas. Tanto el diagnóstico, que señala la fragmentación geográfica, racial y cultural del país, como el proyecto, que propone la construcción "desde arriba" de una Nación Estado fuerte y moderna, buscan apuntalar la dominación oligárquica naturalizándola, promoviendo los valores y la "visión del mundo" de su clase, valiéndose de la manipulación de las representaciones de la nación y sus poblaciones, y estereotipando a estas últimas para definir sectores integrables y sectores refractarios a la modernidad (Klarén, 1991: 240).

Ese orden simbólico busca sostener un orden político que debe controlar, reprimir y excluir a los sectores pre- o extra-capitalistas de la población, para tornarlos gobernables. Como sucede en toda América Latina, también en el Perú de entresiglos la ideología positivista se constituye en la matriz mental dominante; a través de ésta se realiza el examen de la realidad nacional.

Además del evolucionismo, que ofrece una explicación del progreso social como una secuencia de estadios sucesivos de desarrollo creciente, liderada por la "civilización" europea (Gruzinski, 2000), y del cientificismo, que confía en la ciencia como fuente última de toda verdad, forma parte de esa serie de ideas que integran la episteme positivista, una lectura en clave médica, que concibe la sociedad como un "organismo enfermo" que debe ser "remediado" (Terán, 1987: 12). La mayoría de los intelectuales positivistas de Perú y toda América Latina coinciden en señalar la crónica inestabilidad política y el estancamiento económico, como los factores fundamentales que impiden el "progreso" social.

\section{Racismo y racialismo}

Ahora bien, ¿cuál es la causa de estos males? Para ellos, la respuesta está en la composición racial de la sociedad. La mayoría de los intelectuales orgánicos de los regímenes oligárquicos llega a la conclusión de que "la América española está [...] enferma de su población" (Fell, 1994: 580). La presencia de "razas inferiores", principalmente "indios" y "negros", y su influencia negativa sobre el mestizaje (que da como resultado productos "híbridos" y "degenerados"), explicaría el retraso o las frustraciones de la modernización. De ese modo, la raza llega a ser un elemento central del pensamiento social latinoamericano.

Si bien el pensamiento romántico había elaborado una suerte de "razón racial", aunque sin pretensiones de sistematicidad científica (visible en Argentina, por ejemplo, en la 
tradición iniciada por el Facundo -1845- de Sarmiento), hacia fines del siglo XIX e inicios del XX, "raza" toma un sentido más específico y moderno, si se quiere más empírico y antropológico, ligado a la experiencia de la dominación europea de las periferias, y pasa a designar a grupos humanos que se distinguen de otros por sus diferencias físicas heredadas y permanentes (Hale, 1991). El ascenso del liberalismo, cuya postulación teórica de la igualdad de todos los ciudadanos de una nación vino a impugnar la organización estamental de la colonia, también refuerza el predominio de esta categoría, mediante la que se intenta reemplazar la desaparición de las barreras jurídicas y normativas que organizan jerárquicamente las sociedades de América Latina (Bernand, 2001). En esta nueva acepción, "raza" se resignifica para convertirse en el eje de lo que Peter Wade llama "racismo científico", movimiento de ideas íntimamente relacionado con la tradición intelectual europea de pensar la diferencia (Wade, 2000: 22), que surge hacia mediados del siglo XVIII y que gravita con fuerza en el pensamiento occidental hasta mediados del siglo $\mathrm{XX}$, asumiendo en la segunda mitad del siglo XIX el cariz de una doctrina científica. Todorov menciona cinco premisas del racismo científico o racialismo: la afirmación de la existencia de razas y la superioridad de unas sobre otras; la continuidad entre lo físico y lo moral, y la determinación de lo físico sobre lo cultural; la acción grupal sobre la individual; una jerarquía única y etnocéntrica de valores, y una política fundada en el saber, que habilita el pasaje del pensamiento racialista a la acción racista, llegando al sometimiento o incluso a la eliminación de las "razas inferiores" (Todorov, 1991: 115-120).

El racialismo se difunde rápidamente en América Latina, sobre todo entre los intelectuales orgánicos de las oligarquías, quienes a principios del siglo $\mathrm{XX}$ todavía pertenecen a la categoría "blanca" de la población; de ese modo, el racialismo les permite excluirse tanto de las causas de la "enfermedad" de las sociedades nacionales, como de las responsabilidades políticas por el gobierno de las mismas. Ese gobierno se presenta como fundado en un conocimiento objetivo de la realidad, adquirido científicamente (Fell, 1994: 579, y Ansaldi y Funes, 2003: 4).

Los intelectuales latinoamericanos de entresiglos se apropian activamente de las teorías racialistas centrales: Gobineau, Spencer, Gumplowicz, Haeckel, Lombroso, Nordau y Le Bon son algunos de los autores que influyen en la construcción de una visión de las sociedades latinoamericanas como un escenario de la lucha entre razas superiores e inferiores, donde se juega el progreso o la tragedia del continente. 
Sin embargo, sería inexacto atribuir la responsabilidad del racialismo, de manera exclusiva, a la influencia de las teorías centrales, ya que la reflexión jerarquizante sobre los agrupamientos humanos y sus relaciones está fuertemente anclada en la larga historia de las elites intelectuales y dirigentes de América Latina. La población peruana moderna -y la latinoamericana en general- poseen, desde el siglo XVI, una configuración étnica y socialmente diversa, producto del contacto biológico y cultural resultante de la conquista europea, que da lugar a la formación de un mosaico de factores étnicos y culturales heterogéneos, y a una estructura social colonial rígidamente estamentaria.

Desde la instauración de la sociedad colonial se intenta clasificar a esa población diversa a partir de la construcción de representaciones marcadas por el preconcepto racial, como un mecanismo de ordenamiento y control social capaz de fijar a la población, tanto en el espacio geográfico como en rígidos nichos sociales y económicos (Castro Klarén, 2003). La construcción de categorías y divisiones sociales suele ignorar la diversidad, reduciéndola a un sistema de castas - orden simultáneamente social y simbólico--, jerarquizando la sociedad latinoamericana desde una perspectiva fundamentalmente racial.

En Perú, donde existía una voluminosa población originaria previa a la conquista, y con un desarrollo cultural importantísimo, la sociedad adquiere las características de una estructura tripartita, dividida en base a las categorías raciales del indio, el mestizo y el hispano (Klarén, 1991 y 1994).

El racialismo latinoamericano retoma frecuentemente ese orden simbólico construido en la colonia, para oponerse de manera directa a cierta tendencia igualitaria surgida en la época de la Independencia, que considera incompatible con la realidad y, por ello, responsable de la anarquía patológica que padece el continente.

Un elemento fundamental del análisis racialista de entresiglos, que como dijimos busca en la composición de la población las causas de los problemas sociales, es la ponderación de cada uno de los elementos raciales de la nación, que el sesgo etnocéntrico reenvía directamente al "otro" fundamental de cada sociedad, y que desde el comienzo es recortado como problema.

En este sentido, los intelectuales peruanos instalan el tópico del "problema del indio" (Ansaldi y Funes, 2003: 3). En efecto, los intelectuales de la oligarquía blanca de ascendencia europea pretenden definir "científicamente" al "otro" social y cultural, con el objetivo de ver cómo sus características influyen en la organización social -casi siempre, de modo negativo-, y qué medidas se deben tomar para neutralizar dicha influencia. Esa auscultación del "otro" no es -ni podría ser- una descripción neutral de estos sujetos sociales; por el contrario, 
construye concepciones de la alteridad social que operan como mediaciones hacia la internalización de la dominación social oligárquica -fundada en la exclusión de las mayoríasjustificándola, naturalizándola, elaborando un consenso "espontáneo" orientado a dotarla de legitimidad. De ese modo, no sólo se presenta al "otro" como un obstáculo y un freno a la modernidad, sino que aquello resulta, por contraste, en una auto-legitimación de las elites (Ansaldi y Funes, 2003: 21).

Siguiendo a Mercedes Prieto, consideramos esos discursos y representaciones como "poderosos instrumentos que generan y moldean identidades sociales en el marco de una táctica de las clases dominantes, cuya finalidad es lograr gobernabilidad sobre las mayoritarias poblaciones indígenas, apelando fundamentalmente al concepto de "raza'" (Prieto, 2004: 29-30). Como veremos más adelante, dichas concepciones de la alteridad social, junto con las categorías a partir de las cuales éstas son construidas, le traerán serios problemas a los intelectuales que, en los años veinte, intenten romper con la tradición heredada, para instalar una "visón de la nación" y un proyecto social alternativos a la hegemonía oligárquica: al retomarlas en sus discursos, casi siempre con la manifiesta intención de reformularlas, reactivarán -a veces "sin querer", y a veces con una intencionalidad subrepticia- los sentidos ideológicos que los intelectuales racialistas dejaron marcados al construir esas representaciones. Así por ejemplo, el concepto de "indio", tan central en el indigenismo de los años veinte, presenta en este sentido innumerables problemas.

\section{El racialismo en Perú a comienzos del siglo $X X$}

Como hemos señalado, el objetivo principal de este trabajo es abordar las diferentes concepciones de la alteridad social presentes en el indigenismo peruano, miradas en perspectiva respecto de las construidas por la intelectualidad racialista, intentando observar rupturas y continuidades, así como también dar cuenta de su funcionamiento en tanto mediaciones hacia ciertas posiciones y proyectos políticos. Comencemos viendo con más detalle qué ocurre con estas teorías, a inicios del siglo XX, en el campo intelectual peruano.

La Universidad de San Marcos en Lima, lugar de formación de la mayoría de los intelectuales civilistas, es por entonces uno de los centros de difusión más destacados del positivismo racialista latinoamericano, aunque respondiendo a la centralidad más plena del positivismo argentino. Ya en 1897 se presentan en dicha universidad tesis como la de 
Clemente Palma, titulada El porvenir de las razas en el Perú, que sigue los lineamientos teóricos de Max Nordeau y Gustave Le Bon. Para Fell,

\begin{abstract}
...Palma considera como establecidos dos dogmas fundamentales ("leyes", según su terminología): el de la lucha universal por la sobrevivencia y de la jerarquía que divide la humanidad en razas "superiores" e "inferiores". En esta perspectiva, el caso peruano es lamentable ya que la sangre criolla ha sido corrompida por los injertos sucesivos de sangre inferior (india, negra, amarilla). Muy alejado de los esplendores del pasado virreinal, condenado a la degeneración específica de las naciones mezcladas, sólo tiene el país una puerta de escape... una inmigración alemana masiva, aluvión de calidad superior que el Estado debería importar con la mayor urgencia (Fell, 1994: 581).
\end{abstract}

Este punto de vista racialista y patologizante es una de las claves fundamentales del pensamiento intelectual de comienzos de siglo XX, aunque -como vamos a demostrar- se solapa con el espiritualismo - consolidado a nivel continental a partir de la publicación del Ariel de José E. Rodó en 1900-, aún cuando aparentemente se trate de dos epistemes en conflicto. Tal es el caso de la nueva generación de intelectuales que surge a principios del siglo XX en Perú, llamada "generación del 900" o "generación arielista".

En efecto, en Perú, la gravitación de esta matriz espiritualista tendrá una gran fuerza en el campo intelectual. Estos intelectuales, entre los que cabe destacar a los hermanos Francisco y Ventura García Calderón, a José de la Riva Agüero y a Víctor Andrés Belaúnde, fueron los primeros en reflexionar sobre el Perú de un modo sistemático y global, con el objetivo de formular un proyecto nacional modernizador (Gonzáles, 1996). Nos interesa destacar que la reflexión de estos autorres sienta un precedente ineludible en el campo intelectual peruano de las primeras tres décadas del siglo $\mathrm{XX}$, siendo referencia obligada para todos aquellos que reflexionan sobre diferentes aspectos de la sociedad peruana, ya sea para pensar con ellos, o contra ellos. Instituyen un marco y un modo de pensar, y también los temas que ocupan el centro de la reflexión intelectual durante buena parte del siglo XX: la identidad nacional, el problema del indio, el lugar del Perú en el continente, el rechazo de la injerencia norteamericana, la industrialización y la postulación de la necesidad de un proyecto nacional (Gonzáles, 1996: 52). En términos generales, son conocidos y reconocidos por el énfasis culturalista de las respuestas que plantean a estos problemas, vinculadas a la creación de una identidad nacional y continental, en las que la noción de "ideal”-clásico, hispánico, latinoocupa un lugar central. No pretendemos desconocer la veta modernizadora en sentido capitalista del Perú - práctica, pragmática, material- que hay en el pensamiento de los arielistas (Gonzáles, 1996: 222), pero nos interesa enfatizar el rol que cumplen en la 
sedimentación, en el campo intelectual peruano, de elementos idealistas vinculados a la tradición instituida por el Ariel de Rodó.

Formados por el positivismo de la Universidad de San Marcos, estos intelectuales realizan, como señalamos, una serie de cuestionamientos a los determinismos del racialismo positivista que, sin embargo, no logran abandonar, así como tampoco logran abandonar sus temas y conceptos. Lo que sí hacen es abrir un espacio al idealismo filosófico y, con él, una vía de salida frente a la mirada patologizante sobre América Latina (Hale, 1991: 41). La tensión entre el pesimismo racialista y el optimismo espiritualista será una constante fuente de ambigüedades en sus diagnósticos y proyectos (y también, una señal de distanciamiento crítico respecto del pensamiento de los sectores más tradicionales de la oligarquía, con el cual, no obstante, no logran romper del todo). Sin embargo, el mensaje es claro: si bien el panorama racial es desalentador, hay esperanza para las sociedades latinoamericanas, gracias a la presencia de un "espíritu latino" o de una "cultura latina" que puede funcionar como base de la unidad nacional y continental. Sin embargo, esa "esperanza" trae aparejado un borramiento de las alteridades sociales y de las culturas subalternas.

La corriente anti-materialista y espiritualista hace uso del concepto de "raza" en un sentido histórico y cultural, y no antropológico. Por ello, en el enfoque de la alteridad social y en las reflexiones sobre la realidad nacional, representa una temprana bisagra entre el racialismo y el culturalismo emergente en torno a las décadas del veinte y del treinta.

En gran medida, el latinismo de esta generación se erige en contra del avance imperialista de los Estados Unidos, que el Ariel identifica con el utilitarismo y el materialismo modernos. Sin embargo, el rechazo del avance moral de la "cultura sajona" no implica un rechazo de la modernización capitalista ni de los capitales norteamericanos, que adquieren cada vez más peso en la economía peruana, considerados como los factores de un progreso occidentalizante. De hecho, estos intelectuales creen encarnar una selecta elite, portadora del ideal (y por ello, imprescindible), capaz de consolidar una oligarquía cultivada y progresista, para llevar adelante las reformas necesarias para la integración del país al circuito internacional del capital, en abierta disputa con las fracciones más tradicionales de la oligarquía, conformadas por hacendados del interior del país - gamonales-que adhieren a una tradición señorial de la producción y de la dominación social.

Los arielistas consideran que, por su carácter "semifeudal", también estos sectores de la clase dominante son un obstáculo para la modernización. De allí que impulsen, tanto desde puestos de gobierno como desde los principales diarios y revistas, la reforma de un Estado que conciben como arcaico, en favor de un Estado liberal moderno, para maximizar su 
eficacia y extenderlo a todo el territorio, imponiendo un modelo centralista de gobierno. Como sistema político, impulsan una democracia parlamentaria. Sin embargo, sólo el $3 \%$ de la población accede por entonces al voto, y aunque el partido gobernante controla el aparato electoral, recae una y otra vez en el fraude o la manipulación (Klarén, 1991: 269). Además, el Parlamento no representa a los diversos estratos y grupos regionales, sino fundamentalmente a fracciones de la oligarquía, muy poco a sectores de clase media, y nada a los sectores subalternos modernos y tradicionales. Por añadidura, este órgano representativo está fuertemente sujeto al decisionismo del Poder Ejecutivo. Los intelectuales apoyan esta conducción paternalista de un "hombre fuerte" capaz de "oír las voces de la raza", por considerar que es la forma correcta en que se deben gobernar las poblaciones mestizas del continente -siguiendo los lineamientos de la "política criolla"-, para consolidar la armonía y el orden, necesarios para el tan deseado progreso. La idea que subyace es relegitimar el pacto oligárquico "modernizándolo", para consolidar la refundación civilista de la nación, pero sin revisar las exclusiones a que dicho pacto daba lugar, y que abarcaba prácticamente a la totalidad de las clases subalternas (Gil Lázaro, 2004: 135).

\section{La "generación arielista" del 900:}

entre la estigmatización racialista y el borramiento culturalista del "otro"

Tanto José de la Riva Agüero (1885-1944) como Francisco García Calderón (1883-1953) provienen de familias aristocráticas, tradicionalmente ligadas al campo político e intelectual del Perú. Compañeros de la carrera de Filosofía y Letras en la Universidad de San Marcos, son actores fundamentales de la formación intelectual surgida en Lima hacia principios del siglo XX, denominada alternativamente "generación futurista", "generación arielista" o "generación del novecientos". En este apartado exploraremos con cierta profundidad las representaciones de la alteridad social en en dos de sus ensayos más representativos: Carácter de la literatura del Perú independiente (1905) de Riva Agüero, y Las democracias latinas de América (1912) de García Calderón.

Carácter de la literatura del Perú independiente, texto fundacional de la generación del 900, fue escrito por Riva Agüero en Lima en 1905, para ser presentado como tesis final en la Universidad de San Marcos. Las democracias latinas de América fue producido en París, en 1911, en cuyo campo intelectual García Calderón desarrolló, en los treinta y seis años que duró su estadía en Europa, la mayor parte de su trayectoria como ensayista, 
desempeñando simultáneamente funciones diplomáticas para el gobierno peruano. El texto de Riva Agüero es un ensayo de crítica literaria; sin embargo, su inclusión en el corpus de la investigación resulta pertinente ya que, como dice el autor, su desarrollo conduce a "conclusiones que tienen algo de sociológicas" (Riva Agüero [1905] 1962: 305). De manera más directa, el ensayo Las democracias latinas de América es presentado por García Calderón como un estudio de la realidad latinoamericana.

García Calderón señala la "anarquía y el mestizaje" como los males fundamentales que turban la existencia de América Latina, haciendo suyo el punto de partida del positivismo racialista, que "adjudicó a la composición racial de las sociedades latinoamericanas la causa más reveladora de los frenos al desarrollo" (Funes, 2006: 74), "especialmente de aquellos países que -como México, Bolivia o Perú- conservaban un denso y supérstite fondo indígena" (Terán, 1987: 12). De allí parte también Riva Agüero, quien deriva de la composición racial no sólo las características del tipo "literario nacional", sino también un diagnóstico y un programa para Perú que rebasa el ámbito artístico o cultural, y abarca la política, la economía y la sociedad. Acorde con estas premisas, ambos autores analizan los diferentes caracteres de las razas que poblaron América del Sur desde la conquista: íberos, indios y negros.

En los dos ensayos el concepto de raza aparece como un elemento fundamental del análisis. Ambos lo utilizan con un sentido próximo al concepto de "raza histórica" común a Taine y Le Bon (Todorov, 1991: 182-185). Los dos postulan que lo fundamental de cada raza es lo que denominan alternativamente su "alma", su "genio" o su "espíritu", y que consideran conformado por un conjunto particular de "caracteres psicológicos" o "morales" acumulados a través de la historia, y tanto transmitidos como transmisibles por herencia. Estos caracteres, que explican -o mejor, determinan- la evolución de las razas y los comportamientos de los individuos que las componen, derivan de sucesos de la historia de esos agrupamientos humanos ("la historia hace a la raza"), influyendo también el medio y la interacción con el medio (entendido como el clima, el paisaje, el territorio y la geografía). Sin embargo, como veremos más adelante, aparecen, en el tratamiento de algunas alteridades sociales, elementos residuales de un racialismo vulgar, fuertemente determinista, donde lo biológico $-\mathrm{y}$ no lo histórico- parece determinar lo moral ("la raza hace la historia"). Esta oscilación establece numerosas tensiones en la obra de los ensayistas peruanos de esta etapa, dando como resultado discursos ambiguos, e incluso por momentos contradictorios.

Por una cuestión de espacio, obviaremos el análisis que ellos hacen de la raza española, de la cual se consideran parte. Basta con señalar que tanto García Calderón como 
Riva Agüero (que como dijimos, pertenecen a la elite criolla) ubican la raza íbera -explícita o implícitamente- en el lugar superior de la jerarquía racial que establecen. Se trata de una jerarquía única de valores, de origen etnocéntrico, y que sirve de cuadro evaluativo desde el cual emiten juicios universales. En base a ella, el "otro" es siempre identificado en términos de carencia con respecto al modelo propuesto. Por añadidura, los autores consideran que el carácter de esa raza es constitutivo de la identidad de América Latina.

En Carácter de la literatura del Perú independiente, Riva Agüero reconoce, cuando describe la raza india, que los indígenas tuvieron, antes de la conquista y "a pesar de su barbarie", algunos trazos de cultura, como el establecimiento de un "imperio" "teocrático y comunista", el desarrollo de ciertas condiciones literarias o algún tipo de refinamiento artístico y arquitectónico. Sin embargo, Riva Agüero considera que la tradición cultural indígena está definitivamente rota, y por ello, es semantizada constantemente por medio de metáforas de la ruina y de la muerte. En un pasaje, Riva Agüero se refiere a "la caduca pompa de esas ruinas que cubren todo el territorio, de esos templos y castillos derruidos que entristecen nuestros más rientes paisajes con la melancolía de las grandezas muertas" (Riva Agüero [1905] 1962: 188). En el plano de la literatura, manifiesta una violenta revulsividad ante la inclusión de temas y motivos relativos tanto al pasado indígena como a la cultura popular serrana del presente:

La historia incaica tiene mucho de exótica y extraña para nosotros: no la sentimos con el afecto íntimo con que apreciamos la Colonia; para los descendientes de español carece del atractivo de lo castizo, de lo que se refiere a la propia raza; y los descendientes de indios tampoco la aprecian mucho, porque han olvidado su orígenes y en su conciencia étnica hubo con la conquista una verdadera y completa solución de continuidad (Riva Agüero [1905] 1962: 189).

La caracterización de exotismo es solidaria con la proyección de un orientalismo ambiguo que oscila entre un sentido positivo -que por contigüidad incluye a los incas dentro de la escala civilizatoria, aunque en una posición inferior a Occidente- $\mathrm{y}$ otro predominantemente negativo (inscripto en la tradición del Facundo -1845- de D. F. Sarmiento, en el que lo oriental se identifica con la barbarie federal -Altamirano, 2005-). Desde esta segunda opción, que recupera hipótesis difundidas en entresiglos, la raza india y su cultura llegan a caracterizarse como "semichinescas" y, en consonancia, se desliza la hipótesis de que los incas serían "pueblos tal vez venidos de Asia" que imprimieron en las "monstruosas Babeles" que edificaron "el rígido y hierático sello del arte oriental y egipcio". ${ }^{6}$ Sin embargo, lo poco 
que hay de positivo en esa representación (inspirada en las discusiones de la arqueología de la época) le es negado al indio del presente, que al "olvidar" sus orígenes como consecuencia de la conquista, queda condenado a una irremediable decadencia.

La tristeza y la melancolía son para Riva Agüero los datos fundamentales del "genio de la raza" india, y se asocian fuertemente con el medio serrano. Pero si en la sierra, ámbito de sociabilidad del indígena del presente del texto, parece a primera vista que "sus habitantes, tímidos y silenciosos, no tuvieran otros sentimientos que la servil humildad y la desconfianza", Riva Agüero advierte que

No hay que engañarse: allí palpita secreta y pérfidamente una hostilidad recelosa y siniestra. El indio es rencoroso; aborrece al blanco y al mestizo con toda su alma; procura engañarles y perderles; si no les declara la guerra franca es por cobardía. En él, como en todos los esclavos, fermentan odios mortales e inextinguibles (Riva Agüero [1905] 1962: 189-190).

Y continuando la despiadada construcción de una otredad amenazante bajo una "máscara de ferocidad", 7 en la que se manifiesta un profundo desprecio -pero también el temor "blanco" a las incursiones indígenas-, afirma que en la sierra y en sus "poblaciones malditas" hay algo de "diabólico" y satánico, cuando no de monstruoso.

Riva Agüero se extiende menos en el tratamiento de la raza negra y, exceptuando unos pocos pasajes, tiende a ignorarla. Considera que "no puede reconocérsele nada que se asemeje a un ideal literario" u otras manifestaciones de cultura (Riva Agüero [1905] 1962: 72). Entre los caracteres fundamentales de dicha raza, que hace extensivo a los mulatos, menciona la petulancia y/o una indisciplinable turbulencia. En comparación con la raza india, la negra no tiene pasado ni origen, y es presentada como la más primitiva de las razas que conforman el Perú, por su carencia de elementos de cultura. Sin embargo, no le parece que esté dotada de la extrema peligrosidad que en cambio se le atribuye a los indígenas.

En Las democracias latinas de América, García Calderón realiza, como lo hacía Riva Agüero un análisis de la raza india en dos tiempos: por un lado el indio del pasado, previo a la conquista y la colonia, y luego, el indio del presente de enunciación. La raza india del pasado es presentada como un agrupamiento complejo y diverso. Reconoce en su interior a

\footnotetext{
${ }^{6}$ Como demuestra Quijada (1996) las discusiones sobre los orígenes diversos de las culturas americanas ya estaban presentes en las intervenciones de los asistentes al I Congreso de Americanistas, celebrado en Nancy en 1875. En ese sentido, la autora señala la importancia de la hipótesis de Vicente Fidel Lopez sobre el origen indoeuropeo de los Incas presentes en el texto Les Races Ariennes du Pérou (1871) publicado en París y de amplia circulación entre los intelectuales europeos y latinoamericanos.
}

${ }^{7}$ La expresión “máscaras de ferocidad” se encuentra en Prieto (2004). 
diferentes grupos, clasificados de acuerdo a la complejidad o simplicidad de sus formas de sociabilidad y de sus estadíos sociales. De acuerdo con esto, encontramos una escala jerárquica que va desde la "tribu primitiva" hasta las "monarquías bárbaras", definidas como "pueblos medio civilizados" (García Calderón [1912] 1979: 8). Las tribus presentan, para el autor, una organización social simple: "obedecían a sus caciques en la guerra y en la paz" y presentaban una diversidad de "lenguas y estados sociales", "desde el canibalismo hasta las primitivas formas de cultura" (García Calderón [1912] 1979: 17). Por el contrario, los "estados bárbaros" de los incas y los aztecas demuestran "una complicada organización política" y se hallan en un nivel social avanzado, con una cultura mucho más desarrollada, visible en la existencia de "leyes, ciudades majestuosas, clases sociales, colegios de sacerdotes, dinastías reinantes, ejércitos organizados, mitos escolares y hasta jeroglifos y astrólogos..." (García Calderón [1912] 1979: 17). Estos elementos los acercan a un status de raza semibárbara o semicivilizada, destacándose la monarquía incaica, que "recuerda los grandes imperios de Asia, China y Asiria" (García Calderón [1912] 1979: 18). En el ensayo de García Calderón, la analogía con oriente parece estar dotada de un sentido predominantemente positivo que se extiende sobre la raza india. En esta dirección, hará posteriormente continuas referencias al "imperialismo japonés" y a la "resurrección" de la raza japonesa, que permitirían inferir el resurgimiento indígena como posibilidad, pero también como amenaza. Tal como advierte García Calderón, "quizá exista una desconocida fraternidad entre el japonés y el indio americano, entre los japoneses amarillos y los broncíneos quechuas, pueblos disciplinados y sobrios". 8

Si Riva Agüero manifiesta un fuerte desprecio por lo Inca, García Calderón parece elogiarlos explícitamente:

Su tiranía minuciosa y benefactora organizó en el viejo Tahuantinsuyo después de largas conquistas, un gran imperio obediente y silencioso, que era la realización anticipada de los ideales de un socialismo de Estado. La propiedad era colectiva y la vida sometida a rígidos reglamentos. Los incas hicieron compulsivo el trabajo, presidieron las faenas agrícolas y al extender sus dominios, respetaron los ritos y costumbres de las razas vencidas (García Calderón [1912] 1979: 18).

\footnotetext{
${ }^{8}$ Bajo esa asociación puede entreverse el eco de las diversas hipótesis acerca de las correspondencias entre culturas, y acerca del origen de la población americana, en debate en las primeras décadas del siglo XX, en el campo de la antropología. Un buen ejemplo de estos debates puede registrarse, por ejemplo, en las "Actas del congreso internacional de americanistas" celebrado en Buenos Aires en 1910, en el marco de los festejos por el Centenario. Al respecto ver Mailhe (2010c).
} 
En este párrafo García Calderón proyecta sobre los indios una serie de elementos propios de la constelación de valores a los que él mismo adhiere y que forman parte del programa que diseña para solucionar los problemas de las repúblicas latinas de América, a saber: la caracterización de "gran imperio", que en su discurso siempre implica un sentido de "vitalidad"; el ejercicio del gobierno por "buenos tiranos", consonante con la postulación de la autocracia y el cesarismo como forma más apta -y que emana de la realidad americana-; un orden social apuntalado por la disciplina y la obediencia; el fomento y la compulsión del trabajo, valor clave de la modernidad y siempre opuesto a la "pereza criolla", y finalmente la existencia de una religión tolerante y no fanática, que pueda operar, a través de sincretismos, como un factor de cohesión social. De esta forma, García Calderón se apropia del imaginario del "pasado de grandeza" de los incas -paradigmáticamente representado por la concepción del mundo indígena del Inca Gracilaso-, para conectarlo selectivamente con su propio programa, obteniendo así una ratificación cultural e histórica del orden oligárquico que se propone legitimar. ${ }^{9}$ Además, los incas son tomados como pruebas de la importancia de Perú, en el marco de la construcción de un relato genealógico de la nación como posible centro civilizatorio de América Latina (Earle, 2006).

Sin embargo, hay un giro radical en el discurso cuando el autor caracteriza al indio del presente de enunciación del texto. En ese momento García Calderón se acerca a la posición de Riva Agüero: establece un corte entre pasado y presente que desconecta a las poblaciones indígenas contemporáneas de esa historia "gloriosa", recuperada por las narrativas liberales de la nación (Earle, 2006, y Prieto, 2004). Simultáneamente, postula la degeneración de la raza india y su descendencia, hecho que servirá de base para la exclusión de los sujetos indígenas y su cultura respecto de la identidad nacional y continental.

En solidaridad con ello, la caracterización del indio contemporáneo pierde densidad e historicidad, desandando algunos pasos hacia una determinación más anclada en la raza física. Los elementos que en el pasado daban indicios de un alto grado de cultura y sociabilidad están ausentes en la nueva descripción. Ahora el indio "vive en la altura donde reina un clima gélido y la eterna soledad", presentándose casi como radicalmente ajeno a la sociedad y a la civilización. Así, el indio parece incluso perder humanidad, al tiempo que se mimetiza con la naturaleza del medio serrano: para García Calderón, "es triste y cetrino como el desierto que lo rodea". Entre los caracteres psicológicos de este indio, cada vez más "otro", predomina la tristeza. No obstante, el autor no quiere cerrar su análisis con esa imagen de un

\footnotetext{
${ }^{9}$ Tomamos el concepto de "tradición selectiva" de Williams (1980).
} 
indio inofensivo en función del servilismo y la resignación. Por ello, menciona la existencia de "comarcas donde el despotismo desarrolló una suerte de resistencia pasiva". Además, señala que, adaptado completamente al medio, se hace fuerte. Este indio resistente es, sin embargo, impermeable a la modernidad, ya que "detesta todo lo que podría disolver sus tradiciones seculares: la escuela, el servicio militar, la autoridad". Ese postulado también sirve como táctica para justificar su exclusión. Citando al racialista boliviano Alcides Arguedas, García Calderón no deja de advertir que "la simulación, el servilismo y la tristeza son sus rasgos característicos, pero la hipocresía y la aspereza son sus energías defensivas. A veces se alza contra sus amos... como en los tiempos heroicos de Túpac Amaru" (García Calderón [1912] 1979: 195). Así, el indio no deja de ser, al menos potencialmente, un "otro" peligroso y amenazante, aunque inferior (Prieto, 2004: 89).

Si García Calderón había partido de un enfoque cercano al racialismo de las "razas históricas", cuando aborda la alteridad negra ese prisma queda totalmente ocluido por el retorno a un racialismo en el que la determinación racial está anclada exclusivamente en el ámbito de lo biológico, pudiendo potenciarse por la influencia del medio tropical. ${ }^{10} \mathrm{El}$ ensayista define a los negros como seres "primitivos", carentes de todo indicio de cultura. La raza negra ocupa el último lugar de la jerarquía racial, por ser completamente refractaria a la "civilización": "se podría fijar una relación necesaria entre la proporción numérica de los negros y el grado de civilización", dice el autor (García Calderón [1912] 1979: 197). Además, señala la ausencia de negros como la causa fundamental del progreso de ciertas naciones latinoamericanas, entre las que destaca principalmente la Argentina.

En líneas generales, existen coincidencias significativas entre Riva Agüero y García Calderón. Ambos van modificando el registro de su racialismo dependiendo de la alteridad social que describen en cada momento: para con la raza íbera o española aplican un racialismo que gira en torno al concepto de "raza histórica" y que, por ello, implica una inflexión hacia el culturalismo, donde gravita cierta idea de perfectibilidad humana, en tensión con elementos biologistas y con un fuerte determinismo; a medida que van

\footnotetext{
${ }^{10}$ Lo mismo advierte Gil Lázaro: "Comparadas con sus comentarios acerca de la población negra, las descripciones que hace García Calderón sobre los indios son positivas y elogiosas" (Gil Lázaro, 2004: 143).
} 
descendiendo en la jerarquía etnocéntrica que presuponen, sus análisis van prescindiendo de los elementos del plano cultural para retornar a un racialismo anclado en la dimensión biológica, que se aplica más rígidamente aún en el negro que en el indio. De ese modo, el racialismo les permite a ambos autores organizar selectivamente los modelos de alteridad con los cuales se opera una definición de la nación.

En consonancia con ello, tanto Riva Agüero como García Calderón formulan una narrativa de la nación que propone al "criollo" - entendido como "el europeo afincado en América"- como el modelo racial privilegiado para definir la identidad nacional peruana y la del continente americano en su totalidad, descartando a las demás alteridades. Esa representación del criollo encarna en definitiva a la elite oligárquica conformada por criollos-blancos-propietarios e hispanoparlantes. Aquí se revela la fuerza con que gravitan el etnocentrismo y el sociocentrismo, ya que etnicidad y clase se superponen y confunden en este tipo de sociedad poscolonial. Riva Agüero y García Calderón proponen, como primera medida, una solución eugenésica basada en el "blanqueamiento" de la población latinoamericana por obra de la inmigración de europeos "latinos", fundamentalmente españoles e italianos, que permita modificar a los sujetos sociales que por su herencia racial se consideran no aptos para el proyecto modernizador.

Y si bien García Calderón avanza mucho más que Riva Agüero hacia cierta reivindicación de la raza india, desanda el camino cuando aborda al indio contemporáneo, intentando evitar cualquier tipo de alianza con las clases subalternas que pueda comprometer la definición de la nación y el continente que postula la dominación oligárquica.

Del mismo modo, cuando estos intelectuales intenten pasar -contradictoriamente y nunca de modo definitivo- del plano de la raza al de la cultura, proponiendo un proyecto político cultural basado en el fomento de la cultura latina (abriendo así la posibilidad de un mestizaje positivo), no lograrán más que transponer al plano cultural los fundamentos de las exclusiones que, hasta allí, se operaban en el registro de lo biológico.

En efecto, el intento de aflojar la determinación biológica da paso, entonces, a un determinismo cultural igualmente jerárquico que vuelve a afirmar "la discontinuidad de la humanidad, dividida [ahora] en culturas que no pueden ni deben jamás comunicarse eficazmente" (Todorov, 1991: 185). Tal es el caso de las razas/culturas sajona y latina, que presentan "contradicciones insolubles" ancladas en la hostilidad mutua de sus "tradiciones e ideales". Al mismo tiempo, de modo sintomático, se postula una impermeabilidad recíproca entre la alta cultura latina y las culturas de las clases subalternas en América Latina, que reproduce -ahora desde el paradigma culturalista- las exclusiones que impone el régimen de 
dominación oligárquico. En consecuencia, el movimiento cultural de constitución de la nación y el continente, basado en el "latinismo" de la elite, avanza sobre el borramiento y/o la exclusión de la alteridad social y cultural.

\section{De la República aristocrática al Oncenio de Leguía:} apogeo y crisis de la hegemonía oligárquica

Si bien la "República Aristocrática" (1895-1919) es un período de estabilidad política y progreso económico sin precedentes en la historia moderna de Perú, durante su transcurso la sociedad peruana experimenta profundos cambios, ligados al ya mencionado proceso de consolidación y expansión de las relaciones capitalistas en el país, que comienza a generar problemas para la hegemonía oligárquica. En este período la estructura social se hace más compleja y fluida, dando lugar a procesos de movilidad social y al surgimiento de nuevas clases y actores sociales. El paulatino ingreso de las masas a la política va precipitando la crisis del orden liberal conservador civilista y la división de la oligarquía.

Se comienza a formar un incipiente mercado de trabajo, aunque de modo variado, dependiendo de las características de las diferentes regiones en que está dividido el país: la costa, la sierra y la selva. En Lima emerge un embrionario proletariado urbano, ligado a los escasos focos de actividad industrial, nutrido por una importante migración desde las provincias del interior.

A la vez, surgen núcleos de un nuevo proletariado rural en las haciendas azucareras y algodoneras de la costa, y en menor medida, en el área serrana del sur, donde coexiste con formas precapitalistas de reclutamiento de la mano de obra por parte de los hacendados (como el enganche o el peonaje por deudas, e incluso formas de trabajo virtualmente esclavistas), junto con formas de producción comunitarias y autogestivas, tradicionales de los sectores indígenas.

Otro núcleo importante del nuevo proletariado es el que se desarrolla en torno a las actividades mineras y extractivas, que crecen con el avance de los capitales norteamericanos en la región andina.

Junto con este proceso de proletarización de las clases subalternas emerge, sobre todo en Lima, un movimiento obrero moderno, que ya en la primera década del siglo XX comienza a desarrollar sus primeras actividades militantes, con una orientación fundamentalmente anarquista o anarcosindicalista, cuyas acciones reivindicativas 
(especialmente las huelgas por un aumento salarial y por la jornada de ocho horas) van empujando la "cuestión social" al centro de la arena política. Ya en ese momento, los sectores reformistas de la oligarquía diseñan un primer proyecto de reformas, que incluye el arbitraje y la mediación estatal de los conflictos entre capital y trabajo, compensaciones al trabajador por accidentes de trabajo, regulación del trabajo infantil y femenino, y duración de la jornada laboral. Sin embargo, estas medidas son bloqueadas por el ala conservadora del partido civilista, que pretende consolidar la exclusión social y política de las clases subalternas (Klarén, 1991 y 2004, y Quijano, 1979).

Paralelamente, en torno a las actividades comerciales de exportación y a la expansión del Estado y su burocracia, surge una nueva clase media con intereses, actitudes y aspiraciones potencialmente diferentes respecto de los de la oligarquía civilista. Los historiadores coinciden en señalar a esa clase media emergente como la base social que alimenta muchas de las nuevas formaciones intelectuales de los años veinte, entre ellas el indigenismo (Klarén, 1991 y 1994, y Quijano, 1979). ${ }^{11}$

La fuerza disruptiva de estas nuevas clases y actores sociales tiene un antecedente importante en el gobierno del demócrata Guillermo Billinghurst (1912-1914), antiguo protegido y vicepresidente de Piérola. Billinghurst en su rol de alcalde de Lima, y recluta a sus seguidores entre la clase obrera de la capital, al atender algunos temas de la "cuestión social": busca mejorar las viviendas populares, la enseñanza y las condiciones de vida generales. En la campaña electoral identifica sus objetivos con las necesidades populares, que simboliza con un pan gigante.

Esta fracción reformista y paternalista de la oligarquía moviliza por primera vez sectores trabajadores y también amplios sectores de la clase media, en favor de la modernización del Estado y de la democratización de la vida política. De hecho, los días de las elecciones, Billinghurst organiza el primer paro general político de la historia peruana, en contra del fraude electoral del partido saliente, ligado al núcleo duro del civilismo (Klarén, 1991: 266-267; Quijano, 1979: 84-85).

Al llegar a la presidencia, Billinghurst intenta ampliar esta política progresista, buscando reconciliar la ruptura creciente entre trabajo y capital, y promoviendo modelos nuevos de relación entre la clase dominante y los trabajadores (Klarén, 1991: 267; Quijano, 1979: 84-86). Redacta un programa que, con ciertas excepciones, legaliza el derecho de

${ }^{11}$ Cabe aclarar que algunos de estos autores realizan una asociación "mecánica" entre clases medias e indigenismo, que nosotros no acompañamos. Por el contrario, intentamos evitar toda concepción reduccionista y epifenomenalista de la ideología, siguiendo los lineamientos planteados por Mouffe (1980). 
organización y de huelga de los sindicatos, establece comisiones de arbitraje, y adopta una posición reticente a la represión. También comisiona a agentes del Estado para que estudien la situación de los indígenas en la sierra sur, donde paulatinamente aumenta el malestar y el conflicto social. Estas acciones le valen a Billinghurst la oposición de todas las fracciones de la oligarquía. Distanciado de su clase, intenta implicar de modo directo a las masas en el proceso político, organizando comités de trabajadores para presionar al Congreso. Un golpe de estado oligárquico-militar lo derroca en 1914.

Retomado el control de la nación por los sectores de la oligarquía civilista más reticentes al relajamiento del modo tradicional de dominación, el comienzo de la Primera Guerra Mundial desata una grave crisis económica por el cierre del acceso a los mercados europeos, que afecta gravemente a una economía centrada en el sector exportador. Esto profundiza las tensiones sociales existentes, desatando una serie de huelgas, no sólo en Lima sino también en los enclaves de plantaciones y de minería. El Presidente civilista José Pardo se ve entonces obligado a introducir las leyes laborales que su partido había rechazado diez años antes. Sin embargo, los sectores conservadores representados por Pardo son incapaces de avanzar en la dirección de la reforma; por el contrario, endurecen su actitud, recayendo en la represión estatal.

La ola de paros laborales culmina en 1919 en una huelga general masiva por la jornada de ocho horas, que paraliza la ciudad de Lima. Para terror de la oligarquía, no sólo los trabajadores se movilizan en su contra, sino que ciertos sectores radicales de la clase media que habían impulsado el movimiento de la Reforma Universitaria -cuyas voces se empiezan a oír cada vez más en la escena política-, se les unen en las calles. Se desata un proceso general de contestación social que conforma las bases para el amplio y heterogéneo frente antioligárquico que se consolida en los años veinte (Klarén, 1991: 268; Quijano, 1979: 95).

Al mismo tiempo, en la sierra sur-Cuzco, Puno, Arequipa- se intensifican los levantamientos indígenas, que en muchos casos toman un carácter sangriento. A diferencia de lo que ocurre en el norte del país, donde las haciendas se habían modernizado en un sentido capitalista. En la región de la sierra sur, los latifundistas no hacen esfuerzo alguno por cambiar los modos precapitalistas de producción agraria. Por el contrario, los terratenientes buscan responder a los momentos de alza en la demanda internacional de lanas y a la dinamización del comercio de exportación, a través de un aumento de la producción basado en la ampliación de sus pastos y rebaños, a expensas de las comunidades campesinas y sus derechos tradicionales, así como también un aumento en la explotación de la mano de obra 
indígena. De ese modo, en 1919 el conflicto social en la sierra se intensifica, articulado en torno a la lucha entre haciendas y comunidades por el control de la tierra, el agua y la mano de obra, que constituyen los principales factores de producción (Klarén, 1991: 262-263).

Finalmente, la negativa del régimen oligárquico a modificar su carácter antidemocrático y excluyente endurece la protesta social, y produce también la fractura definitiva con los sectores de la clase dominante que buscan profundizar las reformas sociales para garantizar la reproducción del sistema capitalista. Ese mismo año, Augusto B. Leguía capitaliza el descontento social contra la dominación oligárquica-civilista. Su discurso reformista y sus ataques a los civilistas le ayudan a ganar el apoyo de importantes sectores de la clase media y la clase trabajadora. Aunque tiene ventaja electoral, Leguía toma el poder mediante un golpe de estado que desaloja totalmente del gobierno a los civilistas. Estos últimos son asediados, perseguidos y deportados; en sólo un mes, Leguía termina con 25 años de hegemonía civilista, separando por primera vez en el siglo XX a la oligarquía del poder (Klarén, 1991: 271; Quijano, 1979: 93).

La mayoría de los historiadores coincide en señalar este momento como el inicio de un largo período de crisis de hegemonía en Perú, que hacia los años treinta se volverá una verdadera crisis orgánica.

\section{Hacia la conformación de una tradición intelectual crítica:}

los aportes de Manuel González Prada

En este contexto sociopolítico, se da una fuerte revalorización del pensamiento radical de Manuel González Prada (1844-1918), que ya desde fines del siglo XIX emprende una crítica temprana a la dominación oligárquica. Sus ideas serán inspiradoras de la tradición intelectual indigenista de los años veinte en el Perú, de la que los indigenistas son herederos directos.

González Prada, salido de las propias filas de la oligarquía, emprende el primer cuestionamiento a la hegemonía oligárquica. Formado en el positivismo de finales del siglo XIX, rechaza todos los valores e instituciones tradicionales de la sociedad peruana, que considera "feudales", como la religión y la iglesia católica, los terratenientes y el ejército. De una inicial posición liberal crítica, González Prada se va corriendo -no sin tensiones- primero hacia el anarquismo libertario, y ya hacia el final de su vida, hacia posiciones socialistas (Klarén, 1991). 
Considera que la clase dominante peruana no logra trascender la esfera de sus intereses de clase, y por ello, no puede hacerse cargo de la reproducción de la sociedad en su conjunto, ni mucho menos puede encarar el proyecto de formar una verdadera nación moderna, ya que sus intereses de clase están por encima de los de la patria (Quijano, 1978). En esa incapacidad para organizar la nación, ubica también la causa de la derrota en la Guerra del Pacífico (1789-1883). La nacionalidad hispánica que propone la oligarquía excluye a las mayorías nacionales; es lógico entonces que los subalternos no se identifiquen ni con sus superiores ni con una guerra que consideran ajena. De ahí que González Prada proponga una nueva imagen de la nacionalidad, en la que el "indio" ocupa un lugar central, en abierta oposición con el modelo de alteridad propia de los intelectuales orgánicos de la oligarquía. "La Nación está formada por las muchedumbres de indios diseminados en la banda oriental de la cordillera" (González Prada [1904] 1964: 333), afirma provocativamente González Prada, en una frase que será luego vertebradora de los discursos indigenistas de la década del veinte.

Junto con esta redefinición de la nación, González Prada realiza un fuerte cuestionamiento del enfoque racialista dominante, y del pesimismo de los teóricos centrales y locales, que en cierto modo posibilita esa nueva "visión de la nación" y del continente.

En uno de sus textos más importantes, el manifiesto "Nuestros indios" (1904), critica varios de los postulados racialistas, principalmente la afirmación de la existencia de razas y la jerarquía de las mismas, considerándolas parte de una "cómoda invención" de la dominación (González Prada [1904] 1964). Rechaza también las ideas del darwinismo social, como la lucha por la vida, la selección del más apto y la eliminación de los débiles. Afirma que estas ideas son orgánicas a la dominación de una minoría descendiente de los conquistadores, que explota y subyuga al indígena, buscando el reconocimiento de la "superioridad de los blancos y por consiguiente su derecho a monopolizar el gobierno del Planeta, nada más natural que la supresión del negro en África, del piel roja en Estados Unidos, del tágalo en Filipinas, del indio en el Perú" (González Prada [1904] 1964: 333). González Prada invierte irónicamente el racialismo hegemónico para construir una imagen que bestializa al blanco, en un movimiento que señala un primer quiebre radical con el racialismo implícito en la tradición intelectual peruana (e incluso, latinoamericana, en paralelo al antirracialismo de otras figuras "marginales” y contemporáneas como el cubano José Martí y el brasileño Manoel Bonfim). ${ }^{12}$

\footnotetext{
${ }^{12}$ Sobre la crítica al positivismo hegemónico en "Nuestra América" de Martí ver Ramos (1989). Para el caso de Bomfim ver Mailhe (2011), especialmente capítulo II.3, "Multitudes y margen en el ensayismo de entresiglos".
} 
Apelando a un discurso alegórico de fuerte efecto persuasivo en la movilización política del lectorado, González Prada advierte que "el animal de pellejo blanco", que frecuentemente tiene "corazón de tigre" y "alma de cerdo", posee un instinto de rapacidad que lo hace más irracional que un insecto: "Las hormigas que domestican pulgones para ordeñarlas, no imitan la imprevisión del blanco, no destruyen a su animal productivo" (González Prada [1904] 1964: 334; cursivas nuestras). Pero González Prada rompe con la asociación determinista entre raza blanca y carácter explotador, abandonando rápidamente el racialismo -aunque no sin recaídas-, cuando afirma que hay dominadores de todas las razas, señalando la primacía de la clase por sobre la raza. Da el ejemplo de los mestizos "encastados", a los que "poco les ha importado el dolor y la muerte de sus semejantes, cuando ese dolor y esa muerte le ha rendido unos cuantos soles de ganancia" (González Prada [1904] 1964: 336). La crítica se dirige a los grupos dominantes en tanto "clase", que se consideran portadores de una mentalidad precapitalista, que es postulada como el núcleo del carácter feudal que persiste en la sociedad peruana, y del cual forman parte tanto los "señorones de Lima", como los "gamonales de la Sierra". Nuevamente lo que se señala es que estos grupos no logran exceder el plano del interés de clase más inmediato, atentando contra la reproducción del sistema por la eliminación de las fuerzas de trabajo, sin lograr entonces constituirse en una clase verdaderamente hegemónica, esto es, en una burguesía moderna.

En particular, González Prada discute expresamente la concepción racialista de la alteridad que acusa al "indio" de "refractario a la civilización", y afirma que si el indio del presente se encuentra en inferioridad de condiciones es a causa de la "servidumbre" a que ha sido sometido desde la conquista, y que ello no equivale a una imposibilidad para "civilizarse" por su constitución orgánica. Aunque el indio puede educarse como cualquier otro individuo, González Prada no cree que la educación pueda redimirlo. Por eso afirma que "la cuestión del indio, más que pedagógica, es económica, es social", por lo que sólo puede resolverse mediante el acceso a la propiedad que es el factor que más rápidamente cambia la psicología del hombre. Tampoco cree en la filantropía ni en la transformación "moral" de los dominadores arrepentidos: "el indio se redimirá merced a su esfuerzo propio" (González Prada [1904] 1964: 342-343). Tal como veremos, esta ruptura operada por González Prada gravita con fuerza en el discurso de los indigenistas de los años veinte, aunque muchas veces no con la radicalidad de su primera enunciación. 
Cambio en el clima de ideas, surgimiento de una nueva intelectualidad y conformación de un frente antioligárquico en los años veinte

En toda América Latina, la Primera Guerra Mundial significa un importante quiebre con respecto a Europa en tanto faro de "civilización" y modelo de sociedad. Las ideas de Razón, Progreso y Civilización, pilares del encumbramiento europeo, se resquebrajan junto con el desarrollo de una guerra que deja un saldo de muerte y destrucción sin precedentes en la historia. En las grietas de esas certezas, muchos intelectuales latinoamericanos comienzan a repensar creativamente las identidades nacionales y continentales.

Simultáneamente, el ingreso de las masas a la escena política hace entrar en crisis el orden liberal, e inaugura un cuestionamiento acerca de los límites de la nación, en términos de volumen, repensando inclusiones y exclusiones, y en términos históricos, buscando nuevas genealogías (Funes, 2006: 16-19).

Del mismo modo, la Revolución Rusa y la Revolución Mexicana ofrecen una imagen vital de las periferias, no sólo potenciando el valor de las ideologías para transformar las sociedades, sino también proveyendo un modelo factible y netamente americano para quebrar el orden oligárquico.

Las políticas reformistas y el enfrentamiento de Leguía con el civilismo garantizan, desde el poder, el desarrollo de un movimiento de crítica social al orden, la sociedad y la cultura oligárquicas, que se venía desarrollando incipientemente desde hacía algunos años. En los inicios de su gestión, Leguía apoya manifiestamente a los movimientos juveniles que exigen la Reforma Universitaria, así como a los incipientes grupos indigenistas, conformados por intelectuales regionales y limeños, que se hacen eco de los conflictos entre indígenas y campesinos en las áreas serranas del interior del país (Zeballos Aguilar, 2002: 39-42).

Desde principios de siglo, pero más intensamente hacia la década del veinte, se da una extraordinaria expansión de la esfera educativa y cultural. Si bien la educación primaria se expande de manera relativamente homogénea, junto con la matrícula y la población de maestros, tanto en Lima como en las regiones del interior los ámbitos de educación secundaria y universitaria son muy escasos y frecuentemente muy caros. En la mayoría de los casos, sólo las personas de clase media y alta acceden a los niveles superiores de educación; es por ello que muchos de los nuevos intelectuales asumen vías alternativas de educación y aprendizaje cultural, como el autodidactismo y el periodismo de ideas.

Por otro lado, aunque pudieran afrontar los gastos, los provincianos deben migrar permanentemente a las capitales departamentales -frecuentemente, a Lima- para asistir a la 
Universidad. Las demandas por el acceso a la educación universitaria y la democratización de esa institución, llevadas adelante por el movimiento de la Reforma, dan cuenta de la presión que estos nuevos sectores ejercen sobre las instituciones del Estado oligárquico.

La experiencia de la migración, tal como señala Williams (2002) para el caso de las vanguardias europeas, es un importante factor de relajación de las prácticas intelectuales tradicionales, permitiendo el surgimiento de perspectivas críticas y rupturistas. Simultáneamente, el predominio en 1900 de las profesiones liberales y literarias, típicas del letrado tradicional, se equilibra ahora con el desarrollo de instituciones y disciplinas técnicas (como la ingeniería y la agronomía), de las ciencias sociales (como la sociología y la antropología) y de todas las áreas del arte y la cultura. Sin embargo, todavía persiste una baja especialización del trabajo intelectual, por lo que muchos de los nuevos intelectuales combinan varias especialidades y múltiples pertenencias disciplinarias.

En estos años también se da un boom de publicaciones de libros y revistas especializadas, dedicadas en su mayoría a abordar directamente los problemas del país. Correlativamente a estos emprendimientos, surgen muchos grupos intelectuales de redactores, colaboradores y promotores culturales. Otro dato relacionado con este proceso es la masificación del público lector, empujado por el crecimiento de la tasa de alfabetización.

En este contexto, hacia 1923 comienza a definirse con claridad un frente antioligárquico. Muchos de los intelectuales que habían adherido a Leguía durante los primeros años de su gobierno comienzan a quitarle apoyo, en una actitud crítica hacia su creciente autoritarismo, su control fraudulento del Congreso y su cercanía con los capitales estadounidenses, interpretada esta última como una subordinación al imperialismo norteamericano.

Para 1922 Leguía empieza a dejar de lado las políticas reformistas con que había llegado al poder, y recurre a la represión de las huelgas de los trabajadores y de los levantamientos de los indígenas en el sur. Así, reedita el modo oligárquico de ejercer el poder. En 1923, propone la consagración de Perú al Sagrado Corazón de Jesús, con el objetivo de ganarse el favor de la Iglesia. La medida desata una enorme oposición; diversos sectores se movilizan masiva y violentamente en las calles, bajo el liderazgo del entonces dirigente estudiantil Víctor Raúl Haya de la Torre (Klarén, 1991: 275).

Este clima de ideas le da un nuevo impulso a la revisión crítica sobre la nación, iniciada no sólo por Manuel González Prada, sino también por toda una tradición que parte 
del pionero indigenismo literario. La novela Aves sin nido (1889) de la cuzqueña Clorinda Matto de Turner se considera un antecedente central en el surgimiento de este movimiento estético. Dicha obra denuncia la explotación y opresión de los "indios" en un pequeño poblado andino, por parte del prefecto, el cura, el juez de paz y el "tinterillo" local. Esa usurpación se logra gracias al analfabetismo de los indígenas.

Esa novela tuvo una rápida recepción en Lima y actuó como catalizador de la reflexión sobre el "problema del indio" y su progresivo desplazamiento hacia el centro de la agenda intelectual peruana, inicialmente como objeto de reformas políticas y sociales, y luego gradualmente, como eje en torno al que se replantea la identidad nacional (Klarén, 2004: 304-305).

Sobre esa tradición discursiva (estética, literaria, ensayística y política), en el segundo lustro de la década del veinte se consolidan nuevas escuelas indigenistas, nucleadas en torno a lo que la historiografía peruana llama "generación de 1919". Esta nueva formación intelectual, protagonista del movimiento de la Reforma Universitaria y de la experiencia de educación popular de las Universidades Populares González Prada, busca dejar de lado el gusto por el exotismo que se dejaba entrever en los estudios de las generaciones anteriores, para dar paso a objetivos más militantes y revolucionarios, ligados al nacionalismo y/o al incipiente socialismo.

En Lima se forma la más importante escuela indigenista -junto con la de Cuzco-, en torno a la revista Amauta (1926-1930) dirigida por José Carlos Mariátegui, en donde también participan Haya de la Torre y otros apristas, hasta la ruptura en 1928 motivada por la definición socialista del autor de los Siete ensayos de interpretación de la realidad peruana. Siguiendo la matriz inaugural de González Prada, Mariátegui, tal como veremos en profundidad más adelante, identifica abiertamente el indigenismo con el socialismo, y postula que el problema del indio no es racial, cultural o educativo, sino económico y social, por lo que sólo puede solucionarse mediante una reforma agraria radical capaz de liquidar el sistema latifundista de propiedad de la tierra vigente en Perú (Klarén, 2004: 305-306).

Del mismo modo, en la ciudad lacustre de Puno se forma el indigenista Grupo Orkopata, integrado por un conjunto de intelectuales y artistas aglutinados en torno de la figura de Gamaiel Churata, quien entre 1926 y 1930 dirige la revista literaria y política indigenista Boletín Titikaka (Schwartz, 2002 y Zeballos Aguilar, 2002). 
Retomando entonces los objetivos enunciados en la introducción a esta tesis, veamos con más profundidad qué tópicos y contradicciones sesgan uno de los discursos canónicos del indigenismo peruano de los años veinte, considerando especialmente el caso del intelectual indigenista cusqueño Luis Valcárcel. Atenderemos tanto al contenido de su ensayo Tempestad en los Andes (1927) como al itinerario intelectual que reconstruye autobiográficamente en sus Memorias (1981). 


\section{Representaciones de lo indígena en Tempestad en los Andes de Luis E. Valcárcel}

Valcárcel es uno de los primeros intelectuales ligados al emergente campo de la antropología en Perú. Hijo de un comerciante y una mujer proveniente de una familia tradicional y prestigiosa, de ascendencia española, fuertemente católica y vinculada a instituciones culturales y gubernamentales a nivel regional, Valcárcel -como muchos de sus contemporáneos-, se inicia en la vida intelectual a partir del periodismo de ideas, para luego comenzar una larga trayectoria académica en la Universidad de Cusco, donde interviene en diversas disciplinas y áreas del conocimiento, fundamentalmente la historia y la arqueología, pero también el derecho (Valcárcel, 1981: 111-115).

La modernización y el desarrollo regional de Cusco en un sentido capitalista, son algunos de los principales objetivos de Varcárcel en su juventud. Veamos esta cuestión con más detalle.

Luego de la reforma de la Universidad de Cusco (que logra el desplazamiento de sus autoridades tradicionales, impulsada en 1909 por la generación de Valcárcel y José Uriel García), el rectorado queda en manos de un joven norteamericano, Albert Giesecke -designado por el entonces Ministro de Educación Manuel Vicente Villarán, por recomendación de Francisco García Calderón-, a quien el gobierno peruano había solicitado reformar el sistema educativo. Giesecke termina siendo una suerte de mentor de Valcárcel y los demás intelectuales cusqueños, cosa que quizás explique el llamativo silencio de Valcárcel en Tempestad... respecto del tópico del imperialismo norteamericano, tan extendido en los años veinte. La gestión de Giesecke le da a la Universidad de Cusco un perfil positivista, pragmático y moderno, orientado al estudio científico para el desarrollo social y cultural de la región. En palabras de Valcárcel, 
El propósito de nuestro rector $-\mathrm{y}$ que fue recogido por sus alumnos- era suscitar la realización de estudios de utilidad general e inmediata [...] que permitieran crear una atmósfera económica, atraer la atención de los productores y obrar decididamente sobre ellos, advirtiéndoles las consecuencias de su poco cuidado con las tierras, de su falta de técnica en la industria y de su menosprecio por la labor del campo (Valcárcel, 1981: 154).

Reconociendo esa influencia, Valcárcel afirma que:

Las ideas de progreso y desarrollo estuvieron presentes en mis primeros estudios, como lo testimonian mis tesis universitarias escritas entre 1912 y 1916. En La Universidad del Cusco, su nueva organización propuse cambios que pondrían a nuestro centro de estudios al servicio del desarrollo regional. En La cuestión agraria en el Cusco, escrita en 1913, me referí al porvenir agrícola cusqueño y, por último, en Los problemas actuales indiqué que la paulatina descentralización del sistema de gobierno era una condición básica para el desarrollo del departamento (Valcárcel, 1981: 155). ${ }^{13}$

Esta matriz incipientemente desarrollista acompaña el sentido en que interpretamos las denuncias contra la dominación gamonalista, como parte de un programa de reformas que persigue la modernización capitalista de la nación, y muy en particular de la región cusqueña, a la que se quiere reposicionar más favorablemente en relación al contexto nacional.

Con la publicación de Tempestad en los Andes (1927) Valcárcel interviene en la reflexión intelectual sobre la nación y sobre el lugar que en ella deben ocupar los indígenas. En algunas áreas del ensayo, se acerca a un diagnóstico que tiende a despatologizar a estos sujetos sociales, negando su inferioridad racial. Ese discurso reparador, que por momentos se acerca a una suerte de racialismo positivo, en principio rompe con la mirada hegemónica de entresiglos que concebía a los indígenas como sujetos antisociales, peligrosos y refractarios a la modernidad (Fell, 1994). En ese sentido, Valcárcel postula que las causas de la inferioridad indígena son sociales, y denuncia la explotación y la opresión a la que los someten los hacendados, así como también la ausencia de políticas y métodos educativos adecuados para su inclusión social. En consonancia con esa posición denuncialista, en algunos pasajes vincula fuertemente al indígena con el trabajo, entendido como valor clave de la modernidad, y subraya la identificación de la comunidad indígena con la armonía social.

\footnotetext{
${ }^{13}$ Con estas tesis Valcárcel se gradúa en Letras, en Ciencias Políticas y Administrativas, y en Jurisprudencia (Valcárcel, 1981: 155).
} 
Sin embargo, como veremos, en otros momentos del mismo ensayo estos subalternos vuelven a ser definidos como problema y como peligro, bajo una reactualización de las visiones miserabilistas del racialismo hegemónico en entresiglos, que suspende la despatologización que mencionamos anteriormente. La vía por la cual se reactivan los ideologemas residuales ligados a la barbarie es la asociación de lo indígena con el orden de la naturaleza, por influencia del telurismo presente en la literatura y el ensayo latinoamericanos del siglo XIX. De hecho, la tempestad mencionada desde el título es, como veremos, la principal figura retórica con la cual Valcárcel ilustra la potencial activación social del colectivo indígena, e incluso su radicalización, a punto de desencadenarse. Esto prepara, en el ensayo, la postulación de la necesidad de que sean los intelectuales indigenistas de Cusco -aptos por su proximidad geográfica y espiritual con lo indígena- quienes intervengan para resolver ese problema.

\section{Un manifiesto indigenista}

La voluntad de desencadenar una respuesta colectiva ante un problema específico (una de las características del género ensayo, según Weimberg, 2004: 36) es el objetivo primordial de Tempestad en los Andes. En palabras de Valcárcel, Tempestad... "agita" el "problema indígena". ${ }^{14}$ Lejos de las pretensiones de coherencia teórica y epistemológica de los textos científicos - tan habituados a la descripción, la narración, o la explicación racionales-, el texto prioriza la voluntad política de movilización ideológica. Para ello se vale de todos los recursos a su alcance, combinando varios géneros y formas discursivas. El resultado es una mezcla heterogénea y polimorfa (también propia del ensayo) que incluye reflexiones, desarrollos teóricos y conceptuales, transcripciones de conferencias, e incluso aforismos y cuentos (que ponen en diálogo el ensayo de ideas con la ficción literaria "de tesis").

En la primera parte del ensayo predomina la modalidad del cuento corto. Martina Avanza, en su investigación sobre el periódico de orientación indigenista El comercio de Cusco -del que participa Valcárcel, entre otros intelectuales indigenistas-, afirma que ese diario

\footnotetext{
${ }^{14}$ En una carta de 1926 a Mariátegui, Valcárcel afirma: "Tengo otro volumen pequeño: Tempestad en los Andes en el que agito el llamado problema indígena" (Mariátegui, 1994: 1753).
} 
...prefería tratar acerca de los Incas a través de cuentos, de extractos de piezas teatrales o de poemas, en vez de hacerlo con artículos de arqueología o de historia. Y lo hacía porque la forma literaria, al contrario del registro científico caracterizado por una cierta distancia frente al objeto, les daba a los periodistas una mayor libertad de expresión y así suscitaba en el lector, con mayor facilidad, un sentimiento de identificación (Avanza, 2005: 140).

Del mismo modo, en Tempestad... las situaciones, lugares y personajes que se construyen en los relatos son lo suficientemente abstractos, están lo suficientemente diluidos en categorías genéricas, como para habilitar la construcción de tipologías sociales y de ciertos esquemas rígidos de relaciones sociales.

En el ensayo, Valcárcel suplanta la demostración por un calidoscopio de imágenes y neologismos que tienden a eludir, a partir del fragmento breve y la sintaxis simple, las complicaciones lógicas (Mangone y Warley, 1992: 37). Esta marca de modernidad, a la que se suma el carácter fragmentario de la escritura, aleja el texto del modelo tradicional de ensayo, producido por la generación del novecientos, y lo aproxima a los manifiestos de las vanguardias estéticas y políticas de las primeras décadas del siglo XX.

En una carta dirigida a Mariátegui, Valcárcel define Tempestad... como una "película serrana" orientada a exhibir su visión de lo que ocurre detrás de las montañas, lugar en que instala el corazón del mundo indígena. El término “película” expresa bien esta intención modernizadora, que busca acercar el ensayo a las nuevas formas de reproducción técnica propias de los primeros años del siglo, en este caso el cine -pero también la fotografía y el teatro-, a la vez que refuerza la intención de trabajar el lenguaje escrito de modo que apunte a la conformación de imágenes-ideas que movilicen afectivamente al lector.

En este sentido, el objetivo manifiesto del texto es postular una nueva imagen de la nación peruana, definida como popular, indígena y andina, alternativa a las representaciones heredadas de entresiglos. Esa meta lo instala, sin duda, en una posición de ruptura muy significativa respecto de la tradición intelectual hegemónica.

El epígrafe con el que se abre el libro - una cita de Manuel González Prada- ilustra bien esa meta:

No forman el verdadero Perú las agrupaciones de criollos y extranjeros que habitan la faja de tierra situada entre el Pacífico y los Andes; la Nación está formada por las muchedumbres de indios diseminados en la banda oriental de la cordillera (Valcárcel [1927] 1970: 19).

Esa nueva representación de la nación implica, necesariamente, una reformulación de la alteridad indígena tal como la concebían José de la Riva Agüero y Francisco García Calderón. En Tempestad..., la concepción del indio tiende a ser resemantizada positivamente, 
buscando generar empatía con el lector (Valcárcel, 1981: 246). El indio pierde fundamentalmente su condición de obstáculo al desarrollo, condición que se desplaza hacia otros referentes sociales.

\section{Mediaciones intelectuales}

El ensayo se divide en seis partes conexas. Retomando la analogía con el cine de principios del siglo XX, podríamos decir que se organiza en "actos", a través de los que se propone “exhibir lo que ocurre detrás de las montañas” (Mariátegui, 1994: 1791). Valcárcel se ofrece como mediador entre ese universo inaccesible, amurallado por los Andes, y un lector culto y moderno que desconoce lo que ocurre en ese mundo del "otro". Como una road movie, el ensayo despliega un viaje sinuoso con vocación antropológica de conocimiento y exposición del "otro", buscando una "esencia" nacional mediante un deslizamiento múltiple: geográfico hacia la zona andina del interior del país; histórico hacia el pasado precolombino, y social hacia lo subalterno indígena. En ese recorrido, el sujeto de enunciación hace de guía y de intérprete, como mediador privilegiado, con el objeto de poner en comunicación lugares que se encuentran separados por la distancia y los hábitos culturales de una nación fracturada (Ortiz, 1998: 30).

Mientras recorre la tierra del "otro", Valcárcel hace, por momentos, de profeta del pueblo indígena, y va anunciando, mediante afirmaciones fuertes de la subjetividad indígena, el advenimiento del "Nuevo Indio". El autor da por hecho la existencia de una cosmogonía indígena que puede resucitar a través de su discurso y de su actividad intelectual, permitiéndole a la "raza india" salir del primitivismo al que fue condenada por la conquista.

En la primera parte del ensayo, denominada también "Tempestad en los Andes", se anuncia el "resurgimiento" indígena a partir de alegorías construidas con materiales provenientes de la cultura inca, que Valcárcel identifica con el "Inkario":

Un día alumbrará el Sol de Sangre, el Yawar-Inti y todas las aguas se teñirán de rojo: de púrpura se tornarán las linfas del Titikaka; de púrpura, aun los arroyos cristalinos. Subirá la sangre hasta las altas y nevadas cúspides. Terrible Día del Sol de Sangre (Valcárcel [1927] 1970: 26). 
En estos pasajes, Valcárcel parece estar dirigiéndose, más que a los subalternos, a un fondo afectivo "indígena" introyectado por las propias elites, ya que el vocabulario continúa remitiendo al repertorio refinado del modernismo estético (linfas, cúspide son cultismos que así lo evidencian), para sugerir ese renacimiento cultural indígena.

En este sentido, el estilo parece buscar un equilibrio entre la mitología indígena y la estética modernista todavía al gusto de la elite. La propuesta de un relato epifánico y la actitud predicativa que gravita en Tempestad... son gestos también habituales en los manifiestos vanguardistas en general (Mangone y Warley, 1992: 38). Por eso Tempestad... puede considerarse como un manifiesto indigenista, guiado por el objetivo de dar la "buena nueva" de un "milagro": la "génesis de la Nueva Indianidad" (Mariátegui, 1994: 1792), novedad de la que el propio autor se considera descubridor: “...nos hemos dado cuenta con oportunidad de la inminencia de un próximo nuevo ciclo de cultura andina..." (Valcárcel [1927] 1970: 76).

Los términos bíblicos reafirman el carácter híbrido del ensayo, donde el imaginario católico se mezcla, a pesar del manifiesto anticlericalismo de Valcárcel, con la cosmogonía indígena, recuperando el carácter sincrético que desde la colonia se le atribuía a la religión. La idea de una praxis profética se relaciona, como veremos, con las concepciones elitistas sobre el rol y las prácticas intelectuales de acción política (y estética) vanguardista, propias de los años veinte..$^{15}$

Por momentos, Valcárcel enuncia desde un "nosotros" que lo supone dentro del colectivo indígena -de modo similar a un etnógrafo: busca "hacerse nativo"-, mientras que en muchos otros casos se ubica en lo que considera las antípodas de lo indígena: el conjunto de las clases dominantes peruanas. Esta diversificación identitaria da un indicio de la gran cantidad de sujetos que Valcárcel busca interpelar, a la vez que funciona como un síntoma de la dificultad de conciliar en torno de sí mismo subjetividades y visiones del mundo tan disímiles, que dan como resultado un yo fragmentado, saturado de contradicciones.

En ese desplazamiento imaginario, que va desde "detrás de las montañas" hacia el Pacífico, Valcárcel trabaja las concepciones del "indio", del "mestizo" y del "blanco", sus relaciones mutuas y el efecto de su presencia en la sociedad peruana, manteniéndose en un sugerente silencio respecto de otras alteridades sociales de Perú, como por ejemplo los

\footnotetext{
${ }^{15}$ De hecho, desde otro punto de vista, Portantiero (1978: 76), al analizar la Reforma Universitaria, considera esta perspectiva bajo el rótulo de "teoría mesiánica" de la "joven generación".
} 
descendientes de africanos y de asiáticos, y los mestizos e indígenas migrantes a las grandes ciudades, en proceso de plena inserción en la modernidad.

\section{Racialismo, telurismo}

La tarea de construcción de representaciones de la alteridad social es acompañada por ciertos desarrollos conceptuales, que si bien no tienen pretensiones de coherencia epistemológica, parecen ineludibles para un intelectual que busca legitimarse, entre otras vías, por medio del conocimiento científico del tema que aborda.

Valcárcel afirma que cada raza tiene una esencia, que se encuentra en íntima relación con el medio ambiente en que está emplazada: "la raza existe en tanto se arraiga en un trozo del planeta... Raza y paisaje van juntos, y donde se halla el solar permanece también la raza" (Valcárcel [1927] 1970: 136). La idea de que las razas -y en este caso, también las formaciones nacionales- son producto de su entorno físico, coincide con la noción spengleriana de "alma del paisaje” (Favre, 1994). Para Valcárcel, la raza india es inseparable de la influencia de los Andes y la sierra, del "genio de la montaña" (Valcárcel, 1970: 129). En Tempestad..., plantea que "la sierra es la nacionalidad" (Valcárcel [1927] 1970: 124). Sierra y costa, Cusco y Lima, serán opuestos polares en su discurso, reforzando así la esencialización de un binarismo previamente consolidado en la tradición de pensamiento nacional. Inclusive, el ensayista apela explícitamente a una temprana (aunque muy parcial) recepción del psicoanálisis freudiano, ya que postula una correspondencia entre estas dos regiones y el binarismo de género: "En una sociología freudiana, estas dos regiones del Perú representarían dos sexos. Feminidad la costa, masculinismo (sic) la sierra" (Valcárcel, 1970: 122).

Esta definición ambiental de "raza" se combina con una consideración sobre la persistencia e inmutabilidad de las razas ante el paso de la historia. La influencia de una naturaleza andina inmutable supone el despliegue de una continuidad esencial entre la raza india del pasado y la del presente, pues como el paisaje, no cambia. Además de la recepción de La decadencia de Occidente (1918-1922) del filósofo alemán Oswald Spengler (cuyo impacto en el indigenismo latinoamericano es verdaderamente notable), ${ }^{16}$ Valcárcel recupera,

\footnotetext{
16 Spengler, Oswald (1918-1922). Der Untergang des Abendlandes. Umrisse einer Morphologie der Weltgeschichte. $1^{\mathrm{er}}$ volumen: Viena, 1918. Primera edición en español: Spengler, Oswald (1923-1927). La decadencia de Occidente, Madrid, Calpe. La recepción de esta obra por parte de los indigenistas latinoamericanos, supone una adecuación de la teoría spengleriana de los "ciclos culturales" a favor de las culturas indígenas frente a la decadencia de Occidente. Para profundizar sobre la recepción de Spengler en
} 
para estos tópicos, la obra de algunos autores representativos de la tradición intelectual latinoamericana afín al telurismo, fundamentalmente la del boliviano Franz Tamayo y la del argentino Ricardo Rojas. De este último, Valcárcel cita un fragmento, titulado "Ley de Continuidad de la Tradición", del que no especifica la fuente: ${ }^{17}$

Atahualpa fue muerto, y el indio fue cristianizado en la misión o esclavizado en la encomienda. Pero aquella brusca interrupción es sólo una apariencia de teatro, la ilusión de un instante. El río de la tradición autóctona ha caído en un abismo hacia el siglo XVI, pero seguirá su curso subterráneo para reaparecer más tarde [...]. Atahualpa ha muerto; pero resucitará en Túpac Amaru a fines del siglo XVII, y después de la independencia, en el proyecto de Belgrano para coronar a un descendiente del Inca (Valcárcel [1927] 1970: 138).

La influencia de ese telurismo indigenizante es extendida por Valcárcel más allá de los indios, a todos los agrupamientos humanos que habitan la región andina: todo el que vive en la "banda oriental de la cordillera" está dotado de espíritu indígena, y es por ello espiritualmente afín al indio. De esa forma, los indigenistas, sin ser indios, pueden considerarse poseedores (y por ende potenciales representantes) del "espíritu de la raza".

Varios autores han señalado la íntima relación que tiene esta inflexión telúrica del indigenismo de Valcárcel con las ideas regionalistas de la elite de Cusco, que tiene entre sus objetivos lograr una legitimidad política de amplitud nacional, en oposición al centralismo excluyente de las viejas oligarquías limeñas, que monopolizan la cultura y la actividad política, así como también, en otro plano, se apropian de los excedentes económicos generados en el interior del país (Avanza, 2005; Fell, 1994, y Favre, 1998).

En el campo intelectual, las posiciones centralistas son representadas por figuras tales como Francisco García Calderón (quien propone, por ejemplo, la eliminación de las universidades regionales). En contraste con esta perspectiva, la matriz regionalista que gravita en el discurso de Valcárcel tiene un peso muy importante en todo el indigenismo cusqueño (Deustúa y Rénique, 1984). En sus Memorias, Valcárcel señala que uno de los objetivos fundamentales de la "escuela cusqueña" es precisamente la valorización regional. Los ideales de la "escuela cusqueña" se centran en los siguientes objetivos:

...defensa del indígena contra la opresión gamonal; campaña anticentralista y reconquista de la posición orientadora del Cusco en el panorama nacional; regionalismo político, económico y

América Latina y sobre el papel jugado por Quesada, ver Cagni (s/f) y Mailhe (2021).

${ }^{17}$ En verdad, se trata de un fragmento de su ensayo Eurindia (1922: 92-93). La primera aparición de Eurindia es de 1922 (se edita en el suplemento dominical del diario La Nación). Como libro se edita en 1924 en Buenos Aires bajo el título Eurindia. Ensayo de estética fundado en la experiencia histórica de las culturas americanas. 
cultural; exaltación del pasado prehispánico, en especial del Imperio Incaico, y estudios del medio regional y de las comunidades indígenas (Valcárcel, 1981: 141).

Retomando los desarrollos de Valcárcel en torno al concepto de "raza" que utiliza en Tempestad..., esa esencia invariable, que los Andes determinan sobre la "raza india", es aquello que define como "ruralismo" o "agrarismo" (Valcárcel [1927] 1970: 113 y 121). ${ }^{18} \mathrm{El}$ autor concibe a los pobladores aborígenes como "los campesinos ahistóricos de Spengler" (Valcárcel [1927] 1970: 24). La esencia de la raza es vivir en contacto con la naturaleza y ser, por ello mismo, refractaria a la civilización urbana. El contacto permanente con la tierra, a través del trabajo agrario, ejerce una influencia positiva sobre el indio: purifica y vitaliza la raza, dándole "eterna juventud". Bajo este enfoque neorromántico, el indio es presentado como un sujeto racialmente determinado para ser eternamente trabajador rural. Esta idea es la base de la nueva concepción de la alteridad indígena que construye Valcárcel, mediante la cual busca relegitimar al indio en base a su asociación con el trabajo, valor clave de la modernidad. El autor intenta que esta idea funcione como un nexo con elementos propios de una perspectiva materialista sobre el "problema del indio", al postular que el indio es "por naturaleza" un trabajador.

A través de esta comunicación atípica, de dos concepciones que sin duda pueden considerarse opuestas, Valcárcel se acerca a la postulación del "problema del indio" como un problema social, económico y político. Así se aproxima a la perspectiva de Mariátegui tanto en sus Siete ensayos... como en otros textos publicados por este autor en Amauta y en otras revistas culturales de los años veinte, aunque -como veremos- sólo se acerca parcialmente y de manera problemática.

Una vez establecida la asociación entre indio y trabajador, Valcárcel no avanza hacia una lectura materialista de las relaciones sociales, al tiempo que retorna recurrentemente al tópico de la lucha como dinámica natural de las relaciones entre razas y culturas, o entre esencias telúricas divergentes, como las de la sierra y la costa. Además, la rígida asociación entre indio y campesino fija al indígena en un rol social subalterno -el de trabajador rural-, del que "por naturaleza" no podría librarse para alcanzar otros niveles, bajo nuevos esquemas de dinámica social.

\footnotetext{
${ }^{18}$ El término "agrarismo" remite a la Revolución Mexicana, un fenómeno que, como dijimos, tuvo gran influencia sobre la reflexión de los intelectuales latinoamericanos de los años veinte. Ver Bobbio (1995, T I: 19).
} 
Junto con este residuo epistemológico, proveniente del determinismo finisecular aún activo en su discurso, Valcárcel también apela frecuentemente (y de manera contradictoria) al concepto de "cultura" para definir los agrupamientos humanos. En un pasaje de Tempestad... afirma que

Cada personalidad, cada grupo, nace dentro de una cultura y sólo puede vivir dentro de ella, como el pez en el agua. Esta relación universal entre el ser vivo y la naturaleza que le rodea se resuelve en el problema de la cultura. Vamos por la tierra con nuestro propio mundo a cuestas; conocemos, pensamos, sentimos según el conocer, el pensar y el sentir de la propia cultura. No existe el Hombre abstracto, no ha vivido nunca el ente de razón que ha creado el absolutismo filosófico./ Somos hijos, es decir, herederos de un ser que la Naturaleza y la Cultura han formado. La generación espontánea, la mutación, la vida sin historia repugnan, pues, a nuestra mente (Valcárcel [1927] 1970: 113).

Lo que permite la convivencia tensional en el uso de los conceptos de "raza" y de "cultura" es que la inflexión culturalista comienza a desvanecerse ni bien es enunciada, en la medida en que se introduce para ella el mismo determinismo del medio que se le atribuye a la raza. Además, por momentos Valcárcel alterna ambos términos, utilizándolos como sinónimos:

La raza madre en los Andes supervive. Siguen alimentándola como nodrizas gigantescas. Apagado el luminar tawantinsuyo brillan aún sus resplandores en el despojo humano, como brillan los últimos rayos del sol en las altas cumbres. En la meseta andina, en la sierra del Perú, no ha muerto la gran cultura aborigen (Valcárcel [1927] 1970: 115; cursivas nuestras).

Esa híbrida y contradictoria matriz conceptual le permite, no obstante, dislocar las concepciones de la alteridad social diseñadas por los intelectuales de la generación del novecientos. En Valcárcel, lo primitivo se carga simultáneamente de un sentido positivo de pureza y potencia que se harían carne en el indio. Pureza primitiva, siempre renovada "por el contacto con la tierra", con la naturaleza; potencia que instala la posibilidad del inicio de un "nuevo ciclo" indígena, y que habilita las metáforas spenglerianas de nacimiento y resurrección que proliferan en las primeras partes del ensayo: "Todos los sepulcros se tornan matrices de la nueva Vida", pues "de las tumbas saldrán los gérmenes de la Nueva Edad" (Valcárcel [1927] 1970: 22).

Esta resemantización positiva de lo primitivo, que realizan al mismo tiempo la antropología y las vanguardias estéticas contemporáneas ligadas al primitivismo (Schwartz, 2002; Clifford, 1995), en Valcárcel proviene no sólo de la lectura de Spengler (a quien menciona pero no cita, y que probablemente ha leído en castellano), sino también del 
argentino Ernesto Quesada, quien recepciona y difunde tempranamente el pensamiento de este filósofo alemán. ${ }^{19}$ En efecto, Quesada divulga la obra de Spengler a través de sus cátedras universitarias, y de una serie de conferencias, entre las que se destaca la ofrecida en enero de 1926 en la Universidad de San Andrés -citada extensamente por Valcárcel-, en la ciudad de La Paz, a la ida de un viaje "arqueológico" que concluye en Cusco, guiado por el propio Valcárcel. ${ }^{20}$

Spengler establece una ruptura con el etnocentrismo y el eurocentrismo al cuestionar, por la vía del relativismo, las ideas de progreso y civilización, a la vez que afirma que cada cultura debe ser analizada en sus propios términos. En base a ese relativismo cultural, en América Latina La decadencia de Occidente otorga indirectamente un importante fundamento teórico a las corrientes indigenistas, pues permite invertir las connotaciones asignadas a la oposición "civilización" vs. "barbarie", clausurando la visión del mundo forjada por los intelectuales positivistas orgánicos de la dominación oligárquica.

Los conceptos spenglerianos de "ciclo cultural" y "decadencia" de la cultura occidental son utilizados por Valcárcel, siguiendo el lineamiento previo de Quesada, para disparar la idea del surgimiento del "nuevo ciclo de cultura andina" y, al mismo tiempo, la de "decadencia de la cultura urbana de la raza blanca descendiente de España", que los intelectuales peruanos del novecientos (como en otros contextos latinoamericanos) consideran representativa de Occidente (Valcárcel [1927] 1970: 134).

A partir de este nuevo marco conceptual, Valcárcel logra desarticular algunos elementos que forman parte del imaginario sobre el indígena heredado de entresiglos, aunque sin romper con las categorías y conceptos nodales de ese pensamiento previo: lo que se señalaba como el mayor defecto del indio -el hecho de ser primitivo y refractario a la "civilización"- se transforma en la base utópica de un "resurgimiento" indígena, gracias a la "incontaminación" con el "virus de la decadencia".

Como veremos más adelante, la idea de un ocaso de la civilización occidental se conecta necesariamente con una concepción negativa del mestizaje (y del mestizo como tipo social): en la medida en que lo hispano toca a los sujetos y/o las prácticas (y en algunos casos, incluso predomina en dichos cruzamientos), introduce la marca espuria de la decadencia occidental.

\footnotetext{
19 Quesada, Ernesto (1926). "Spengler en el movimiento intelectual contemporáneo" en revista Humanidades, La Plata, UNLP.

${ }^{20}$ Sobre la relación intelectual entre Spengler y Quesada, y la influencia de este último en la recepción local del pensamiento del alemán ver Cagni (s/f) y Mailhe (2021).
} 
En la sección "Detrás de las montañas", Valcárcel ofrece una serie de postales de la vida del "indio" en lo que se considera su lugar natural, los Andes, y su ámbito de sociabilidad por excelencia, el ayllu o comunidad indígena. El autor ubica el mundo indígena en la geografía andina, aislado de la civilización occidental, manteniéndose en un estadío primitivo, eternamente virgen y al margen de la historia. Para el autor, las comunidades son un reservorio de la tradición inca pronta a resurgir. Hombres y mujeres se mimetizan entre sí y con los animales, la vegetación, la tierra, las montañas y los ríos, junto con el clima y los astros. En la descripción, que apela a palabras e íconos de lo que se considera la visión del mundo indígena, priman las imágenes de armonía, tanto con la sociedad como con la naturaleza:

Los ayllús respiran alegría. Los ayllús alientan belleza pura. Son trozos de naturaleza viva. La aldehuela india se forma espontáneamente, crece y se desarrolla como los árboles del campo, sin sujeción a plan; las casitas se agrupan como ovejas del rebaño [...]. El humillo de los hogares, al amanecer, eleva sus columnitas al cielo; y en la noche brillan los carbones como ojos de jawar en el bosque (Valcárcel [1927] 1970: 37).

Obsérvese el efecto tranquilizador (entre enternecedor e inferiorizante) de los diminutivos (aldehuela, casitas, humillo, columnitas): en la cita, esa ambivalencia anticipa, como veremos, las contradicciones que sesgan todo el ensayo en la concepción de la alteridad. Los indígenas aparecen trabajando alegremente, cantando, colaborando solidariamente en el pastoreo y el cultivo de la tierra: "Moran felices en la comunidad de la tierra y en la universalidad del trabajo", en una "vida comunitaria sin ricos ni pobres" (Valcárcel [1927] 1970: 41 y 116). La intimidad de la relación entre el indígena y la tierra es tal que el trabajo agrícola es representado como un acto sexual o un proceso de fecundación, en el que los trabajadores con sus "chakitajllas viriles", "desfloran" la "virginidad" de la tierra. Los indios aparecen comiendo y bebiendo, entre risas y cantos; se suceden imágenes de abundancia, prosperidad y bienestar, junto con relatos descriptivos de las fiestas populares de la cosecha y los carnavales.

Sin embargo, como veremos, esta armonía de lo indígena queda confinada al espacio de las comunidades que se ubican "detrás de las montañas". Toda vez que en el libro se muestre al indio fuera del ámbito que se le asigna como natural, se presentarán situaciones de conflicto. De hecho, el indio que habita fuera del espacio vital del ayllu, sometido a la 
opresión latifundista, es inicialmente representado por medio de metáforas arqueológicas, como momias, estatuas y monumentos de piedra, en los que sólo son apreciables los vestigios de una humanidad muerta, que se instala en el espacio del "sepulcro" y la "tumba": "En su rostro de esfinge, las cuencas vacías lo decían todo: sus ojos ausentes no miraban ya el desfile de las cosas. Era un pueblo de piedra" (Valcárcel [1927] 1970: 22).

\section{El resurgimiento indígena en la sociedad nacional:}

violencia como respuesta a la opresión

Estos elementos de desconfianza, de simultáneo acercamiento y distanciamiento con respecto a lo subalterno, se hacen evidentes cuando -como adelantamos-Valcárcel describe a los "indios" fuera del microcosmos de los ayllus andinos. Las connotaciones de armonía van dando paso a representaciones que giran en torno a la idea de conflicto social y racial, y que recuperan la asociación de lo "indio" con la "barbarie" y la amenaza, abonando la sospecha acerca del confinamiento de la positividad indígena en el espacio cerrado de las comunidades "detrás de las montañas". Reforzando esta perspectiva, el apartado "La sierra trágica" agrupa una serie de cuentos en los que se describe con lujo de detalles la violencia entre "indios" por un lado, y "blancos" y mestizos por el otro. Valcárcel vuelve a presentar la violencia como la clave predominante de las relaciones sociales entre estos grupos. No se puede negar, sin embargo, el fuerte carácter de denuncia -como dijimos, otro de los aspectos fundamentales del indigenismo de Valcárcel- que hay en esa descripción de la "opresión” del "indio" por parte del "blanco" y sus aliados mestizos.

Esa dominación se presenta simultáneamente con las características de un sistema feudal y de un sistema esclavista. De acuerdo a ello, se construye un estereotipo del "blanco" "terrateniente", "latifundista" o "propietario de hacienda" como tiránico "amo de la gleba indígena" e "insaciable explotador". Esa dominación del blanco se funda en el orden del "garrote y el vergajo"; su arco de brutalidades va desde la violación hasta el asesinato y el ocultamiento de los cadáveres, y su éxito económico se basa en la explotación semi-esclavista del indio y en la expropiación de sus bienes comunales.

Para Valcárcel, el “indio" se encuentra en una situación de inferioridad por causas históricas -y por ello reversibles-, originadas en la conquista, y continuadas en la colonia y aún luego de la independencia, en base al régimen de dominación latifundista que 
describimos. De ese modo, la condición de "obstáculo a la modernización” es trasladada del indio a los gamonales, considerados como verdaderos resabios "feudales".

Valcárcel describe el resurgimiento indio como un proceso que se está desenvolviendo por etapas en el presente enunciativo, y que permanece inacabado, aunque sea presentado como inminente. El autor mantendrá esa tensión intencionalmente a lo largo de todo el ensayo, dándole cierto sentido de urgencia a la cuestión, en base a la cual instala la idea de la necesidad de una rápida intervención. Lo dice sin tapujos: "El despertar de millares de conciencias implica el más grave problema que se haya presentado jamás en el Perú" (Valcárcel [1927] 1970: 133). Como veremos más adelante, él mismo se ofrece para “encauzar" ese proceso.

En un primer momento, Valcárcel presenta el surgimiento de la "nueva conciencia" como una manifestación de venganza del indio contra sus opresores, el blanco y el mestizo. El primer impulso vital de ese ser momificado, el "indio" oprimido, es responder a la violencia dominante con una violencia igualmente cruel y despiadada. Valcárcel describe esas acciones de venganza apelando a tópicos del naturalismo finisecular, e incorporando detalles morbosos que subrayan la explotación y la venganza. En ese sentido, resulta elocuente un fragmento en el que narra la muerte de un hacendado en manos de los indios, apelando al efectismo moderno de la interpelación del lector:

El pobre caballero ha sido descuartizado. Le mataron cuando se hallaba en reposo, sin darle tiempo para la defensa./ Terribles golpes sufrió. Mire Ud. los garrotes ensangrentados. Vivo aún lo arrastraron por las habitaciones y por el patio erizado de agudos guijarros. Las mujeres ayudaban a sus maridos en la perpetración del crimen. La víctima aullaba de dolor y ellas le acribillaban con los gruesos alfileres de sus tupus. Vea usted cómo le reventaron los ojos, cómo le quebraron las piernas y brazos, cómo le desgarraron la piel, arrancándole el cabello (Valcárcel [1927]1970: 72).

En estos pasajes Valcárcel remite a la historia reciente del Perú, signada por una serie de levantamientos indígenas entre 1915 y 1925, en la sierra sur. El ensayista se sirve de estos acontecimientos, frescos en el imaginario social, para presentar a los indios movilizados por el despliegue de una inmensa potencia destructora, contraria a la tranquilizadora representación de sujetos aislados, petrificados y desfallecientes, construida por Riva Agüero y García Calderón. Alejándose incluso de la concepción de indio-trabajador que el autor presenta en otros pasajes, esta imagen del indio vengativo reenvía a la tradición sarmientina que identifica al indio con la barbarie (piénsese, para el caso argentino, en la potencia agresiva -y negativa- de lo indígena expuesta a lo largo del siglo XIX, desde La Cautiva de 
Esteban Echeverría hasta el óleo "La vuelta del malón" -1892- de Ángel della Valle, luego de la "Campaña al Desierto"). Valcárcel noveliza los levantamientos indígenas desde la estética de la violencia vandálica de los desclasados resentidos, recuperando tópicos del terror blanco a la rebelión de los indígenas campesinos, por ejemplo cuando advierte que

La temida irrupción se produjo. A la medianoche, bajo una tempestad de enero, con lluvia a torrentes, cayeron sobre el pueblo los bandidos. Eran cincuenta, sesenta, todos armados de rifles y cuchillos grandes como alfanjes. Asaltaron la subprefectura y las casas de los vecinos principales: saqueo, violación, asesinato, incendio... (Valcárcel [1927] 1970: 59).

Valcárcel señala que ese comportamiento no es natural en los indios, sino que depende de la particular dominación social que se ejerce en Perú. Pero no por ello deja de apelar a los ideologemas de la barbarie, que reponen las "máscaras de ferocidad" construidas por las narrativas liberales de la nación (Prieto, 2004). En estos pasajes hay una manifiesta voluntad de agravar la sensación de amenaza en las clases dominantes, señalando la latencia del peligro. El título mismo del ensayo, Tempestad en los Andes, es elocuente en este sentido, ya que une lo indio con el orden de la naturaleza, con lo telúrico, lo inmanente, lo instintivo y lo irracional. Esta intención se observa claramente en el fragmento citado, donde el ataque de los "indios bandidos" se confunde con la "tempestad de enero, con lluvia a torrentes". En la visión que ofrece Valcárcel, los indios pueden ser una tempestad incontrolable, y en su vorágine pueden arrasar con todo.

De ese modo, la apelación a la naturaleza oscila entre el sentido positivo que instala la posibilidad del futuro -juventud, virginidad, pureza y potencia- y la connotación negativa que reduce al otro a un "medio sujeto", un ser inmaduro que aún no ha cortado el cordón umbilical con la tierra: su rebelión es una tempestad (natural, inconsciente y temida), más que el resultado de la organización racional de un sujeto colectivo libre y consciente de sí. Valcárcel incluso utiliza la metáfora de la oruga, para sugerir una metamorfosis aún incompleta; por ello el indígena se mantiene en un estadío prelógico, instintivo, sin que le esté dado convertirse en un sujeto pleno, masculino, racional y moderno. De ahí que en más de un pasaje el autor se dirija a los indios como "masa indígena antropopiteca", "masa infrahumana", "autómata", "primate” e inclusive "niño grande” (Valcárcel [1927] 1970: 31, 101, 130 y 133-134 respectivamente), todas figuras que habilitan la intervención tutelar y paternalista de un sujeto pleno (en este caso, el propio sujeto de enunciación) como representante tanto de los "otros" como de los intelectuales indigenistas. 


\section{El "nuevo indio": un modelo burgués para la modernización indígena}

En el apartado "Los nuevos indios", Valcárcel describe una nueva etapa en el proceso del resurgir indígena, que da cuenta de una reacción "humana" de los "esclavos". El indio, al adquirir paulatinamente conciencia de sí, empieza a completar su condición de sujeto y a percibirse a sí mismo en pie de igualdad con respecto al blanco, hecho que abre la posibilidad de su integración a la sociedad. Este indio que se iguala al blanco es, para Valcárcel, el "Nuevo Indio", en el que se recorta su modelo deseable de evolución del indígena. La concepción de la alteridad social contenida en esta representación se encuentra tensionada entre la preservación de la diferencia y la "asimilación" del "otro". ${ }^{21}$

Este proceder "miserabilista" parece buscar una reparación simbólica de la alteridad, al acercarla a un modelo "legítimo" (en este caso, el sujeto burgués racional, occidental, masculino y moderno, al que Valcárcel parece adscribirse). Y si bien continúa designando al "otro" como "indio", muchas de las características que Valcárcel celebra en estos nuevos indios remiten a hábitos y valores fundamentales de la sociedad occidental y burguesa: "[El "Nuevo Indio"] posee hábitos higiénicos, viste de americana, reside en limpias moradas [...], es abstemio. Ha aprendido a mirar de frente y a extender la mano en gesto amistoso [...]. Es un hombre" (Valcárcel [1927] 1970: 132).

En este sentido, el postulado de la igualdad entre indios y blancos supone una asimilación que borra las especificidades culturales de la alteridad indígena, bajo la persistencia del etnocentrismo y del sociocentrismo (o etnocentrismo de clase). "El Nuevo Indio" es precisamente aquel que está dejando de serlo. Su "evolución" implica su borramiento.

\section{Representaciones del mestizo y del mestizaje}

Ahora bien; en Tempestad... la conjunción entre los elementos de la cultura occidental burguesa y los sujetos indígenas no es considerada bajo el marco de una ideología mestizófila. Cuando Valcárcel aborda el tópico del mestizaje, retorna a una clave racialista de

\footnotetext{
${ }^{21}$ Los intelectuales asimilacionistas, cuando miran a la alteridad social, tratan de acercarla a los modelos de identidad propios, en lugar de comprenderlos en sus diferencias (Todorov, 1991: 383).
} 
análisis que establece una evidente continuidad con el pensamiento heredado de entresiglos. Como en las raciologías clásicas del positivismo, postula que la mezcla de razas (o como vimos, de razas/culturas) da lugar a sujetos híbridos regresivos. Así por ejemplo afirma que, como consecuencia de la conquista, "nace del vientre de América un nuevo ser híbrido: no hereda las virtudes ancestrales sino los vicios y las taras. El mestizaje de las culturas no produce sino deformidades" (Valcárcel [1927] 1970: 115), o que "los Hombres Blancos [...] violaron a las abuelas y las madres, de cuyos vientres venerados salió el Engendrado, el mestizo, vasallo del Opresor y verdugo del Vencido" (Valcárcel [1927] 1970: 95; cursivas nuestras). Cuando describe los "poblachos" que representan el carácter mestizo (asociando nuevamente el medio y las características de sus habitantes), surgen imágenes particularmente cargadas de preconceptos miserabilistas: el mestizo es transmutado en un organismo en descomposición, carcomido por la enfermedad, detenido en el tiempo, como un "pantano" o "pudridero" en el que predominan las ruinas. La descripción reenvía a la idea de la muerte, en flagrante oposición con respecto al nacimiento y/o la juventud de la indigenidad pura. Los mestizos son comparados con animales e insectos, "gusanos", "arácnidos" y "parásitos", e incluso "cadáveres ambulantes".

Tal como advierten Laplatine y Nous (2007: 744), el zombi, el muerto-vivo, es la figura límite del mestizaje. En Tempestad..., a mitad de camino entre dos opuestos (la vida y la muerte, lo indio y lo hispano), esos sujetos pierden la posibilidad de retornar a una identidad estabilizada y reconocida, y por ello son condenados a una existencia sin sentido: “Gusanos perdidos en las galerías subcutáneas de este cuerpo en descomposición que es el poblacho mestizo, los hombres asoman a ratos a la superficie; el sol los ahuyenta, tornan a sus madrigueras [...]. Nada hacen. Son los parásitos, son la carcoma de este pudridero" (Valcárcel [1927] 1970: 43). O también: “Cadáveres ambulantes, alguna vez abandonan sus habitáculos por breves días [...]. Tardos, como entumecidos, pasan por las calles, de frente a los bebederos. Tambaleantes, con los ojos turbios, abotagados, enrojecidos, miran las cosas de la ciudad con estúpida expresión.” (Valcárcel [1927] 1970: 44). Valcárcel menciona al mestizo como un aliado del blanco en la explotación del indio, y por momentos lo considera peor que el blanco, como en el caso del "leguleyo mestizo" que "explota por igual a blancos y aborígenes" cuando afirma: "Agente para las elecciones, el enganchador para las empresas, el vecino principal, cuya industria más saneada es el vivir a expensas de los obsequios del indio, del soborno del propietario, de los gajes de la función concejil -fondos de municipalidades, recursos del Estado" (Valcárcel [1927] 1970: 43). En este sentido, Valcárcel no hace sino reactualizar la condena racialista del mestizaje, recayendo en un lugar compartido incluso por otros 
indigenismos neorrománticos de entresiglos, que fijan el tópico de la inestabilidad (racial, social, psíquica) del mestizo como el sujeto problemático por antonomasia en las sociedades latinoamericanas. ${ }^{22}$

Ahora bien; no creemos que Valcárcel se oponga de manera taxativa al mestizaje, tal como afirma De la Cadena (2006). De hecho, hay otras concepciones del mestizaje presentes en Tempestad... A la idea de mestizaje negativo que veíamos, y que se puede pensar a partir de una lógica de disyunción entre lo hispano y lo indígena, se contrapone la consideración de la existencia de ciertos mestizajes "felices": los que se dan sobre el territorio indígena, sobre la sierra andina donde la "poderosa inkanidad del pueblo autóctono" absorbe el "espíritu" del otro término con el que se conforma la mezcla. Así por ejemplo, Valcárcel advierte que

Existieron dos coloniajes: el coloniaje de Lima, pleno de sibaritismo y refinamientos, con un acentuado perfume versallesco -la Perricholi su símbolo-; y el coloniaje del Cuzco, austero hasta la adustez, varonil y laborioso... tras de las montañas fue americanizado virilmente el hijo de Castilla. En las sierras lo indio se impone; a las orillas del mar, lo español (Valcárcel [1927] 1970: 123).

Sobre este mestizaje de base serrana e indígena, que tiene a Cusco como lugar modélico, Valcárcel construye su proyecto para suturar la nación peruana dividida: lo "indio" debe extenderse a todo el territorio, posibilitando una indianización de la nación que la haga coincidir con su "esencia". La idea de tempestad puede asociarse también a este proyecto de mestizaje indianizante que el autor llama "andinismo", ya que remite a una fuerza natural que, como el agua de deshielo, o como una tormenta, avanza desde los Andes hacia la costa. Y si es cierto que Valcárcel afirma en algunos pasajes que "un día bajarán los hombres andinos como huestes tamerlánicas" sobre todo el territorio, no nos parece, como afirma Henri Favre, que Valcárcel "sueña con una purificación étnica de la costa criolla a través de las masas indias poseedoras de la fuerza telúrica de los Andes" (Favre, 1998). Por el contrario, termina proponiendo una indianización nacional en base a la expansión de la cultura inca, y el mantenimiento de esas masas indias en el ámbito rural, de modo que el "genius loci, genio de la montaña", domine "por encima de la mixtificación, bajo la cáscara

\footnotetext{
${ }^{22}$ Para el contexto de México por ejemplo, en parte comparable con respecto al peruano, ver la condena del mestizo en la obra del etnógrafo indigenista Carl Lumholtz en El México desconocido, editado en entresiglos. $\mathrm{Al}$ respecto ver Mailhe (2010). Aunque en el marco de una discusión más compleja, la condena del mestizo en el ensayismo mexicano se prolonga hasta la obra de Samuel Ramos (El perfil del hombre y la cultura en México, 1934) y Octavio Paz (El laberinto de la soledad, 1950). En México, el elogio del mestizaje des-indigenizante es desplegado por Manuel Gamio en Forjando Patria (1916).
} 
europea", apenas "en los vastos dominios de la subconciencia” (Valcárcel [1927] 1970: 22 y 129). Retomaremos esta cuestión más adelante.

El retorno de la peligrosidad indígena: ceder algo para no perderlo todo

Esa reemergencia de la perspectiva racialista no es desplegada únicamente en la construcción de las representaciones del mestizo y del mestizaje. Introduciendo un fuerte elemento de tensión en el ensayo, Valcárcel vuelve a proyectarla sobre el indígena del presente de enunciación, más que en las premisas del diagnóstico racialista -postergadas, como vimos, a partir de la apelación a las determinaciones sociales- en la misma imagen estereotípica del indígena peligroso, construida por esa tradición discursiva.

Recuperemos la transformación del "indio" en "Nuevo Indio" a la que hicimos referencia anteriormente. Valcárcel la asocia con una disolución de su carácter naturalmente irracional, para disminuir su peligrosidad. No obstante, el ensayo vuelve a reponer el sentido de amenaza que supone la presencia indígena. En efecto, Valcárcel va deslizando la idea de que el "Nuevo Indio", de no ser rápidamente integrado a la sociedad, puede comenzar a orientarse hacia la acción y hacia su organización como clase, a partir de su auto-reconocimiento social como trabajador. En este punto, el ensayista vuelve sobre lo que Aguilar (2002) denomina la "narrativa de los gamonales", que acusan a los indígenas de querer desatar una "guerra de castas", de encarnar un movimiento separatista y de tener la intención de convertir Perú en un país comunista, argumentos esgrimidos precisamente para motivar la represión de los levantamientos indígenas. Valcárcel utiliza esta narración para “agitar" el surgimiento del "Nuevo Indio" en clave de amenaza: el movimiento indígena está listo para llevar adelante una revolución socialista. Uno de los últimos relatos de Tempestad..., "La gran parada", ilustra muy bien estas connotaciones de peligrosidad que se inscriben en torno a la idea del "resurgimiento" indígena. Vale la pena citar extensamente el texto:

$-¿$ Son quince mil hombres?

-Quizás, pasan de veinte mil.

-iFormidable! Todos visten sus flamantes uniformes de "boy-scouts".

-Que ellos mismos han fabricado, desde la tela y los correajes.

-Y observe usted la marcialidad, la increíble desenvoltura; no parecen los mismos indios humildes y agachados a quienes tantas veces dio usted de puntapiés. 
-Y usted también, amigo mío. ¿Quién entre nosotros, desde niño, no ha tratado así, al pongo, y después al yanacona?

-Es verdad. Mire usted, esto es grave: los indios de este ejército fuera del ejército marchan con insolencia. Fíjese en aquel que manda esa compañía. Qué arrogancia. Parece mentira lo que estamos viendo.

-Sí, es un despertar increíble. En pocos años, de esclavo, el indio pasa violentamente a hombre libre.

- ¿Cuidado! Hay mucho que temer de este brusco cambio. Pueden tomarse un desquite trágico.

-Calle usted, por Dios. Qué sería de nosotros si estos millares de hombres se dan cuenta de todos los agravios recibidos.

-Pero, no sea usted ingenuo, ¿se le ocurre que estas gentes viven en la inconsciencia? No, señor. Han vivido hasta aquí inermes, impotentes, devorando su cólera, su odio al blanco. Mas, cuando puedan, cuando dispongan de la fuerza...

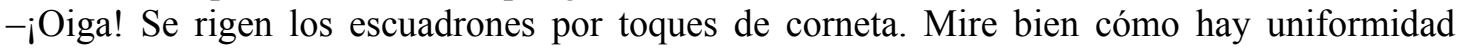
admirable en todos los movimientos. Se quedan muy atrás nuestros soldados. ¿Cómo se explica usted este fenómeno si nuestros soldados son también indios?

-Muy sencillamente. El ejército nacional se constituye por coacción. Sigue siendo el reclutamiento la forma usual de llenar los cuarteles; una verdadera cacería de indios. Este ejército netamente indio se está creando por convicción. Vea la diferencia. Bueno. Ha terminado el desfile; ¿distingue usted? En el atrio de la plaza se ha destacado un grupo, de ese grupo sale un indio, ¿lo ve usted?

-Si, parece que va a hablar a sus huestes. Vamos allá...

-¿Ha oído usted?

-Grave, grave. Esto va a terminar en saqueo. Vámonos. Yo temo por mi familia. Puede haber algo. Seamos prudentes.

-iQué atrocidad! No oí jamás tantas insolencias. Con qué desprecio nos ha tratado a los blancos. ¡Que ya no hay amos ni esclavos! Que la propiedad es de todos. Puro socialismo, comunismo, bolcheviquismo (sic). Estamos al borde de una sima.

-Y no habrá salvación. Apure usted el paso. Lo perderemos todo. Los bienes que nos dejaron nuestros padres, que nos cuestan nuestro dinero, que hemos trabajado toda la vida.

-Eso es lo de menos. Si pudiéramos salvar el pellejo (Valcárcel [1927] 1970: 102-104).

En este diálogo aparece claramente la asociación que mencionábamos antes de las ideas de tempestad con las de revolución socialista indígena. Lo indígena se vuelve a juntar con la barbarie $\mathrm{y}$, simultáneamente, con el socialismo y la revolución. Valcárcel juega con la representación de una fuerza india organizada y disciplinada como un ejército moderno, guiada por un programa indiferenciadamente socialista, comunista $\mathrm{y} / \mathrm{o}$ bolchevique, que propone la abolición de la "esclavitud" y la socialización de la propiedad privada. Esa fuerza está a punto de caer como una "tempestad" sobre los propietarios blancos con mano de obra indígena a cargo, e hispanohablantes -los sujetos de enunciación en el diálogo arriba citado-. En el camino se verían arrastrados - del mismo modo que en la rebelión indígena en la tradición colonial- algunos valores básicos de la sociedad occidental capitalista moderna: familia, bienes, frutos del trabajo, cuando no la vida. 
Esa asociación entre indígenas, socialismo y barbarie representa bien las tensiones del discurso de Valcárcel. Si en algunos momentos parece instalarse en el lugar del deseo del autor, en otros parece deliberadamente construida para generar terror entre los causantes de ese estado de cosas, los “opresores”. De hecho, en algunos pasajes Valcárcel hace un llamado a la "razón", a blancos y mestizos, advirtiéndole al "altanero dominador de cinco siglos" que "los tiempos son otros. Es la ola de los pueblos de color que te va a arrollar si persistes en tu conducta suicida" (Valcárcel [1927] 1970: 27). Valcárcel le sugiere al dominador que ceda algo para no perderlo todo, en una crítica que parece retomar la de González Prada en "Nuestros Indios" (1904), aunque disociada de la perspectiva revolucionaria de su primer enunciador. ${ }^{23}$ La persistencia de ese modo de dominación tradicional, que tiende a la destrucción del indígena, desatará la ola, la tempestad, la fuerza irracional de los dominados.

¿Pero qué se debe ceder? Valcárcel no lo dice. Se puede inferir, por lo que denuncia a lo largo del ensayo, que su objetivo es el relajamiento de las "condiciones de máxima opresión" que impone el modelo semi-feudal y semi-esclavista, que está poniendo en riesgo de disolución a la sociedad. Así, Valcárcel subraya la sensación de amenaza de las clases dominantes, para lograr legitimar la introducción de reformas sociales que -como vimosestán en el horizonte de expectativas del autor desde sus años de formación universitaria.

Otro aspecto en el que Valcárcel sugiere ceder, es el de la integración democrática del "indio". Considera la democracia como "evolución", y la opone al "resurgimiento inkaico": "por el sufragio universal, a la vuelta de veinte años, podría constituirse la Democracia India. Hacia esa meta evolucionamos. Sólo que el renacimiento inkano (sic) se da prisa" (Valcárcel [1927] 1970: 106). Valcárcel remite a la oposición entre evolución y revolución, tópico recurrente en el pensamiento reformista de América Latina. Ernesto Quesada (como vimos, un referente clave para Valcárcel), desde principios de siglo impulsa un programa de transformación liberal-reformista de la sociedad argentina, próximo al de Valcárcel. ${ }^{24}$ En su conferencia de 1926 en La Paz afirma el mismo tópico:

Dado que nuestra América deba ser la cuna del próximo ciclo cultural, la responsabilidad de las clases dirigentes de estos países es enorme, si descuidan educar a las masas indígenas,

\footnotetext{
${ }^{23}$ Como vimos anteriormente, en su artículo de 1904 "Nuestros Indios", Manuel González Prada dice: "Las hormigas que domestican pulgones para ordeñarlos, no imitan la imprevisión del blanco, no destruyen a su animal productivo" (González Prada [1904] 1964: 334, cursivas nuestras). González Prada critica a las clases dominantes peruanas por considerar que la forma en que éstas explotan la fuerza de trabajo indígena pone en peligro la reproducción de la mano de obra y, por ello, la de la sociedad en su conjunto. De allí que las considere incapaces para encarar el proyecto de formación de una verdadera nación moderna.
}

${ }^{24}$ Ver al respecto Tarcus (2007). 
porque el despertar de las mismas puede ser de consecuencias más o menos trascendentales, según sea la preparación de aquellas. No es cuerdo obligar a que se realice por revolución lo que razonablemente puede obtenerse por evolución (Quesada, 1926: 47).

Y si bien Valcárcel no propone ningún proyecto concreto de reformas, las múltiples citas y referencias -directas e indirectas- a Quesada habilitan a pensar que el proyecto de integración de los subalternos indígenas, que vislumbra el ensayo, es similar al enunciado por el intelectual argentino, precisamente en la conferencia citada por Valcárcel en Tempestad... En convergencia con otros textos reformistas (en los que Quesada advierte sobre la necesidad de mejorar las condiciones de explotación de los trabajadores para alejar el peligro de una revolución), ${ }^{25}$ en esa ocasión, en La Paz, antes del viaje a Cusco para encontrarse con Valcárcel, Quesada propone "incorporar a la vida social la enorme masa indígena":

No es cuerdo mantener la enormísima mayoría de los habitantes de estos países como ilotas sin derechos y sin personalidad. No basta acordarles teóricamente la igualdad sino que es menester llevarla a la práctica, con idéntica educación y tratamiento, y no como altruismo doctrinario sino como consideración práctica de estadista, pues la situación es artificial y anómala. Así, por ejemplo, nuestros países se esfuerzan por atraer la inmigración europea, y olvidan que en su seno tienen millones de seres humanos que podrían ser admirables elementos de trabajo si fueran debidamente preparados para ello, con la ventaja de su adaptación al medio y de su natural apego al suelo que los ha visto nacer./ Hay, pues, además del motivo ético de justicia, y del político, de sana organización social, principalmente el de orden económica, de explotar las riquezas de nuestro suelo con esos millones de brazos que hoy no se mueven como debieran porque carecen de iniciativa y porque deliberadamente los mantenemos alejados de nuestro ambiente nacional, como si no fueran ciudadanos de la república. Es decir, estos países están cometiendo la indisculpable torpeza de no utilizar la mano de obra baratísima que el destino les ha deparado [en lo que resulta] una política nacional suicida de los gobernantes latinoamericanos" (Quesada, 1926: 43).

Ambos intelectuales parecen acercarse al mismo proyecto de integración de la población indígena, con el objetivo de evitar la transformación revolucionaria de la sociedad, aunque respondiendo a contextos sociales diferentes: Quesada busca "domesticar" la "peligrosa" mano de obra inmigrante; Valcárcel, fomentar la modernización capitalista del Cusco para asignarle un nuevo lugar en la nación. ${ }^{26}$

\footnotetext{
${ }^{25}$ Quesada, Ernesto (1907). "La cuestión obrera y su estudio universitario", Buenos Aires, Menéndez.

${ }^{26}$ Por el trabajo de archivo llevado a cabo recientemente por Mailhe en el Instituto Iberoamericano de Berlín con el legado de Quesada, sé que no se conservan las cartas entre Quesada y Valcárcel, pero sí aquellas enviadas por Quesada al austríaco Arthur Posnansky, en la Paz, rogándole difunda su conferencia de 1926, ya editada, entre los americanistas del mundo andino.
} 
De hecho, la tensión ante una posible revolución socialista indígena comienza a resolverse en el anteúltimo apartado de Tempestad..., en donde se transcribe una conferencia dictada por Valcárcel en la Universidad de Arequipa el 22 de enero de 1927. Allí, ante un público de intelectuales universitarios -“entre nos"-, Valcárcel se despoja en gran medida de las ambivalencias:

El despertar de millares de conciencias indias implica el más grave problema que se haya presentado jamás en Perú./ ¿Cuáles son los propósitos que abriga el nuevo indio? Porque ya no se trata de la involucración [sic] aislada de aborígenes en el compacto mestizo-europeo: es la masa infrahumana - diez millones de indios en Perú, Bolivia y Argentina- que torna a constituir grupos sociales conexos, que busca la luz y descubre en la caverna interior el fuego perdido de la conciencia racial./ ¿Qué programa tiene formulado la vanguardia nativa del movimiento pan-indianista? [...] ¿Qué resistencia oponerle?/ El block de mestizo-europeos es minúsculo e inerme. Las gentes de color significan el décuplo y han monopolizado el arma. Ya lo dije otra vez, el fusil es indio./ El autómata que hoy dispara dejará de serlo. ¿Y entonces?/ Quién sabe de qué grupo de labriegos silenciosos, de qué torvos pastores, surgirá el Espartaco andino. Quién sabe si ya vive, perdido aún en el páramo puneño, en los roquedales del Cuzco./ La dictadura indígena busca su Lenin (Valcárcel [1927] 1970: 133-134; cursivas nuestras).

Nótese que, en estos pasajes, el problema social ya no es la explotación, sino la posible activación y la radicalización del colectivo indígena, que se presenta como el despliegue de una fuerza natural, como un alzamiento y como una acción revolucionaria, remitiendo incluso al imaginario de la Revolución Rusa.

En este punto, podemos afirmar que, más allá de cierta retórica revolucionaria, Tempestad... busca instalar la necesidad de ese programa de reformas, aunque lo hace mediante un rodeo que consiste en mostrar las potenciales consecuencias sociales de su no implementación. Precisamente, la tempestad mencionada en el título forma parte de una figura retórica con la que Valcárcel busca representar el proceso que podría llevar a los indígenas a revertir la situación de dominación a la que se encuentran sujetos. Ese proceso es concebido por Valcárcel como la emergencia de un nuevo "ciclo cultural"; pero también adquiere, ambiguamente, las connotaciones de una revolución social. El disparador de esa situación es el "despertar" de la "nueva conciencia", que consiste fundamentalmente en la recuperación de la historia de la raza, olvidada por siglos de opresión, y el reconocimiento del lugar que el "indio" ocupa en la sociedad peruana, en tanto trabajador y en oposición a la "casta" dominante. Si bien varias instituciones juegan un papel en ese proceso (incluso las misiones y las escuelas adventistas, o las organizaciones de Boy Scouts, que aportarían una formación moderna para el indio), entre los factores catalizadores de ese "resurgimiento" se 
ubica el propio autor, en su veta profética, hablando nuevamente desde el auto-asignado rol de guía, subrayando el sesgo paternalista de sus concepciones políticas. Pues... ¿quién mejor que los indigenistas (historiadores, arqueólogos) para manipular el "inkario", de modo que, al reimplantarlo entre los subalternos indígenas, permita devolverles la conciencia histórica alienada? Y al mismo tiempo, ¿quién mejor que los indigenistas para poner límite a dicho resurgimiento...?

\section{Un problema "a medida” para los intelectuales cusqueños}

El argumento sobre la emergencia de la dictadura indígena que busca un liderazgo revolucionario -así lo indica la referencia a Lenin- instala las premisas para la intervención de los intelectuales, bajo la particular concepción que tiene Valcárcel de éstos y de su función. Veamos cómo lo afirma el ensayista: "Los que vivimos en el corazón de la sierra poseemos el privilegio de asistir al acto cosmogónico del nacimiento de un mundo, como el viajero que contempla el sublime espectáculo de la tempestad en medio de la llanura azotada por el rayo. Privilegio en el peligro" (Valcárcel [1927] 1970: 134). La revolución indígena naciente, peligrosa como una tempestad, es observada de cerca por Valcárcel y, con él, por los intelectuales indigenistas de Cusco, como espectadores directos y privilegiados, capaces de describir, interpretar y predecir el sentido de los hechos del mundo indígena. En este punto Valcárcel define el papel del indigenismo cusqueño como destinado a "encauzar las formidables energías desplazadas por el mundo que nace detrás de las montañas". De ese modo, se postula a sí mismo (y con él, a su formación intelectual indigenista) como el agente más autorizado para solucionar el problema principal del colectivo subalterno: el posible desborde de las masas indígenas en una acción revolucionaria de clase (y obsérvese que el verbo “encauzar" reenvía a esa acepción del término "desborde"). En este sentido, el diagnóstico del problema social diseña claramente, para su intervención, un espacio de autolegitimación "a medida". En una representación que tiene mucho de autorretrato, afirma:

¿Será presunción nuestra el intento de encauzar las formidables energías desplazadas por el mundo que nace detrás de las montañas? [...]. La única elite posible, capaz de dirigir el movimiento andinista, será integrada por elementos racial o espiritualmente afines al indio, identificados con él, pero con preparación amplísima, de vastos horizontes y ánimo sereno y sonrisa estoica para afrontar todos los reveses, sin perder la ruta en el laberinto de las ideologías (Valcárcel [1927] 1970 : 135, negrita en el original). 
En este párrafo puede entreverse una fuerte continuidad con respecto a la tradición intelectual de entresiglos, vinculada a lo que Lagos (2010) define como "razón oligárquica". ${ }^{27}$ La gravitación del elitismo intelectual implícito en el Ariel (1900) de José E. Rodó es evidente. Valcárcel se adjudica a sí mismo un lugar de autoridad, basado en la posesión de un saber, de ciertos valores mesurados y de desinterés material (“con preparación amplísima”, y libre del riesgo de perderse en "el laberinto de las ideologías"), y enraizado en la afinidad "racial o espiritual" que le confiere su origen serrano (opuesto a los intelectuales y políticos de la capital), para constituir un pequeño grupo de iluminados capaz de encauzar el movimiento indígena: "él vendrá a ser el bautista de ideas que dé nombre a las cosas y luz a los ojos del monstruo ciego" (Valcárcel [1927] 1970 : 135). La figura del "monstruo ciego" repone la ya señalada devaluación del indígena y de las masas en general, bajo la resonancia irracionalista de la psicología de las multitudes de Gustav Le Bon. La "elite" mencionada en la cita no es más que una nueva versión de la oligarquía, modernizada por el saber "sociológico" de la época.

De hecho, Valcárcel termina convergiendo en una línea de pensamiento paternalista y autoritaria, muy próxima a las formas de dominación de los hacendados que pretende combatir en otros pasajes del ensayo, por ejemplo cuando afirma que

La indiada resurgente informe, como una nebulosa, contorneará su personalidad bajo el cincel de verdaderos escultores de pueblos. Admiremos la genialidad del artista que llega, el nuevo Miguel Ángel de este Moisés de la montaña./ Sólo dos alternativas tiene el advenimiento de la Raza resurrecta; significará o la ciega destrucción demoníaca lucha de razas, o la evulsión creadora con término en el Pacto o Contractus, estabilizador vital de todas las variedades étnicas asentadas en el "habitat" peruano./ Los obreros intelectuales estamos obligados a buscar la segunda solución./ ¡Cuántos peligros trae consigo el deslumbramiento para quien emerge "de la negrura mística de los estadios primitivos" en la que, por quinientos años, ha vivido la Raza de los Andes!./ De quienes la guíen depende el futuro (Valcárcel [1927] 1970 : 135; cursivas nuestras).

Esta cita reenvía nuevamente al Ariel, así como también a la imaginación modernista en general, en su asignación de un papel mesiánico al intelectual / esteta que se erige en guía (de los espíritus/ de la sociedad). ${ }^{28}$ No casualmente Valcárcel utiliza la misma metáfora que Rodó

\footnotetext{
${ }^{27}$ Lagos (2010) define la razón oligárquica en Perú a partir de cinco coordenadas: creencia en la superioridad racial, paternalismo, elitismo, aristocratismo cultural, y autoafirmación estamental en la cima de la sociedad.
} 
para describir la acción de la elite intelectual sobre los subalternos, apelando a la figuración del escultor que imprime violentamente su forma, con su cincel, sobre la roca informe que representa a las masas. ${ }^{29}$

El elitismo, el paternalismo y los ideologemas que reponen una mirada devaluadora de lo popular indígena, puestos en juego en las representaciones de la alteridad social (sobre la que se recorta la figura y el rol del intelectual indigenista), señalan una fuerte continuidad con las concepciones oligárquicas sobre la indigenidad.

La apelación al inkario: formación de una (alta) cultura nacional de base incaica

Decíamos anteriormente que el ensayo propone, en sordina, la unificación de la nación a partir de un proyecto de mestizaje cultural construido con elementos provenientes de la cultura incaica. Esa es, a nuestro criterio, una de las claves del proyecto indigenista de Valcárcel. Detengámonos a considerar cómo concibe el autor esa cultura destinada a indianizar la nación peruana.

Por un lado, en Tempestad..., la cultura inca (del pasado y/o de la inmutabilidad transhistórica) se erige en representativa absoluta de "lo indígena". Suprimida por los dispositivos coloniales, es percibida como residual entre los sectores populares indígenas de los años veinte. La apelación al "inkario" que realiza el autor establece una fuerte continuidad con la tradición del folclore del siglo XIX que considera el mito y la leyenda como aspectos fundamentales del pensamiento popular (y en especial, del pensamiento indígena), en tanto estos materiales permiten aprehender el "espíritu" del pueblo y/o de la raza. Esa concepción, heredada del romanticismo, es reactualizada en torno a los años veinte y treinta por varios intelectuales folcloristas en el contexto latinoamericano y, desde diversos paradigmas de análisis, en base a la gravitación del culturalismo y del psicoanálisis aplicado tempranamente en el campo de la antropología (por ejemplo, en la obra folclorista de diversas figuras como Mário de Andrade y Arthur Ramos en Brasil, o Bernardo Canal Feijóo en Argentina). ${ }^{30}$

\footnotetext{
${ }^{28}$ La profecía acerca de la inminente llegada de un Mesías es una metáfora clave, en el imaginario modernista, acerca del papel directriz asignado a los intelectuales tanto en el campo de la política como en el del arte (por ejemplo, es visible en el discurso del Poeta en el cuento "El rey burgués" en Azul... -1888- de Rubén Darío).

${ }^{29}$ Un análisis del papel magisterial de la voz intelectual, como mediador privilegiado en el Ariel, se encuentra en González Echevarría (2001).

${ }^{30}$ Para el caso de Ramos y Canal Feijóo ver Mailhe (2012).
} 
En este contexto, vale la pena rastrear en la biografía intelectual de Valcárcel su interés por recuperar el sustrato mítico y legendario del pensamiento popular indígena. Antes de concentrarse en la arqueología, Valcárcel se aboca desde sus años universitarios a recopilar leyendas populares, que luego publica en el libro De la vida inkaica (1925), con ilustraciones de José Sabogal. En esos trabajos recoge relatos ligados a las creencias, las supersticiones y la religión incaicas, desde un punto de vista histórico y literario, aunque sin un mayor respeto por las fuentes originales -orales y/o escritas-, en un claro indicio tanto de la apropiación "desde arriba" de la voz de los subalternos, como de la condición amateur de su práctica etnográfica y/o como prueba de su interés por llegar al lectorado masivo, indigenizándolo.. Valcárcel recuerda en estos términos su experiencia inaugural a fines de la década del diez:

En 1919, con otros colegas que compartían mis puntos de vista, presentamos un amplio proyecto de investigación histórica, de propagación y difusión de los tesoros artísticos y arqueológicos del Cusco. La Universidad se encargaría de las tareas de recoger, para su publicación, cuentos, tradiciones, mitos, y todo testimonio indígena de las provincias cusqueñas. También se gestionaría la [...] creación de un Museo Histórico-Arqueológico. [El proyecto quedó inconcluso] por falta de apoyo económico [...]. Apena pensar en los invalorables testimonios que deben haberse perdido al desecharse nuestro proyecto (Valcárcel, 1981: 212).

En convergencia con un folclorismo nostálgico y conservador, Valcárcel propone el acercamiento al indígena para buscar vestigios de un pasado en vías de extinción, más que conocimientos acerca de su existencia actual.

Vale la pena recordar que el gusto por los temas incaicos es compartido por la alta sociedad cusqueña, para la cual poseer antepasados pertenecientes a la realeza inca es una fuente de prestigio simbólico, al mismo nivel que el abolengo español. De hecho, esa exaltación del pasado prehispánico, fundamentalmente del Imperio Incaico, denominada “incaísmo”, es una de las fuentes de identificación común de la elite cusqueña, y forma parte de la "alta cultura" de la región. Este "incaísmo" es uno de los sentidos con que Valcárcel usa el término "indigenismo"; el otro remite a la "defensa del indio contra la opresión del gamonal”, apuntando a la situación del indígena en el presente (Valcárcel, 1981: 141).

Esa apelación a la cultura incaica como modelo cultural encubre una estrategia de diferenciación y distanciamiento respecto de la cultura subalterna indígena del presente de enunciación. Veamos el ejemplo que, en este sentido, ofrece Martina Avanza en su artículo “¿Qué significa ser cusqueño?”: 
Los intelectuales del Cuzco hablaban el quechua noble de la época de los incas, un quechua "puro" que se estaba perdiendo y que pretendían restaurar. Al mismo tiempo, estos intelectuales consideraban que los indios hablaban un quechua "degenerado", con la puntuación del castellano y demasiado simplificado. De ese modo los intelectuales indigenistas preferían "identificarse con la nobleza incaica, más que con los indios" (Avanza, 2005: 150).

Al elegir un modelo de alteridad detenido, "de museo", y por ello más manipulable, Valcárcel deja entrever un fondo de desconfianza frente a lo subalterno activo y su cultura, por supuesto no homogénea, diversa y fragmentada, menos controlable y menos "bella", en convergencia con el movimiento que advierte de Certeau (1999) con respecto a la definición intelectual de "lo popular" como objeto de conocimiento.

En consecuencia, Valcárcel considera que son los intelectuales indigenistas (y no los indios) los que mejor representan (los más autorizados para "hablar de" y "por") la cultura “india”, pues el abordaje de lo indígena requiere saberes científicos especializados, como la historia o la arqueología, que sólo los intelectuales indigenistas poseen. De allí se deriva la asignación de una alta misión nacional para estos agentes culturales: llevar adelante la indianización de Perú.

Cabe destacar que tanto la indianización como la legitimación de la antropología converge llamativamente con la propuesta del ideólogo indigenista (y arqueólogo) mexicano Manuel Gamio en Forjando patria (1916), que Valcárcel cita extensamente en Tempestad... En ese ensayo "fundador" del indigenismo latinoamericano, Gamio postula una sutura cultural de la nación fracturada a través del "descenso" de las elites al mundo popular indígena (en una fase de indigenización) para luego alcanzar... una conjunta elevación de la nación hacia la cultura europea (blanca / hispánica / católica).

En la visión de Valcárcel, los intelectuales indigenistas oriundos de Cusco son los mediadores más autorizados (más que los letrados y políticos tradicionales de la capital, pero también más que los propios indígenas) para operar como nexo entre la nación peruana y su "verdadera esencia". En este punto se entrevé la búsqueda de una alianza más simbólica que material con lo indígena, acompañando el deseo "explícito o implícito", de relegitimación del propio sujeto de enunciación y de su grupo, en el campo intelectual y en el campo político nacional.

Entonces, lo indígena legítimo se forma con los elementos de la cultura inca y se presenta como "representativo" de la verdadera "esencia" nacional, pero bajo la condición de 
permanecer como un sustrato museificado, residual e inofensivo, fácilmente manipulable por parte de los intelectuales para, de ese modo -y sólo de ese modo- integrar lo "indígena" en la cultura dominante (occidental, hispánica, moderna). Por el contrario, lo indígena del presente, activo y pujante, se pretende evitar (o llanamente reprimir), tal como vimos en el desarrollo de este capítulo. Esta tendencia "arqueologizante" es común en el indigenismo más conservador de esta etapa. ${ }^{31}$

Simultáneamente, Valcárcel realiza otra maniobra de evasión respecto de las clases subalternas. Su proyecto futuro de mestizaje cultural indianizante -0 mejor, "incanizante"niega en definitiva el mestizaje y a las poblaciones mestizas realmente existentes en el Perú de su tiempo..$^{32}$ Esa "incanización" avanza sobre el borramiento de la diversidad cultural e identitaria de los sectores subalternos, resultando en definitiva tan autoritaria como la "latinización" propuesta por Francisco García Calderón en Las democracias latinas de América. $^{33}$

Contra Leguía: entre la política tradicional-reformista y la "nueva generación”

Algunos aspectos de la trayectoria de Valcárcel en el campo político peruano apoyan el reconocimiento de continuidades con respecto a una concepción oligárquica de la política, que se actualiza -a veces "sin querer", a veces subrepticia e incluso intencionalmente- en sus diagnósticos y proyectos en torno al "problema del indio". Veamos.

Como se observa en sus Memorias (que consideraremos en este ítem como fuente de análisis) Valcárcel combina desde su juventud la militancia universitaria reformista con actividades políticas tradicionales, aunque permanezca ligado a sectores liberales y progresistas. Por "política tradicional” entendemos las prácticas políticas de la democracia restringida, de camarillas, intrigas y negociaciones, limitada a cerrados grupos de notables, habilitados en virtud de la educación, el prestigio y el poder, y cuya sociabilidad se desarrolla en torno al reducido ámbito del club y los salones. ${ }^{34}$

\footnotetext{
${ }^{31}$ Un razonamiento semejante (aunque con un tinte racialista más marcado) sigue Arthur Posnansky, en Bolivia, en la misma etapa. Para Posnansky ver por ej. Stefanoni (2014).

${ }^{32}$ La misma negación del componente indígena podría rastrearse en otros discursos mestizófilos de la década del veinte en América Latina, por ejemplo en Eurindia (1922) de Ricardo Rojas, o en La raza cósmica (1925) de José Vasconcelos. Para un análisis del conjunto de autores de esta etapa, ver Mailhe (2019b).

${ }^{33}$ Sobre las consecuencias de la construcción de un discurso fundante del Estado monoétnico y monocultural (en Bolivia, pero extensible al caso peruano en términos generales) ver García Linera (2008).
} 
La experiencia de Valcárcel en la política tradicional tiene un hito fundamental en su primer viaje a Lima en 1912, comisionado por varios grupos políticos de Cusco, para solicitar la destitución del Prefecto local ante el gobierno central: Valcárcel se entrevista con el Alcalde de Lima, Guillermo Billinghurst, que le consigue una entrevista con el entonces presidente Leguía, y este último accede a la petición que le habían encomendado. Pese a estar afiliado al Partido Liberal, Valcárcel accede a la propuesta del demócrata Billinghurst (por entonces candidato a la presidencia) de sumarse a su campaña como miembro de su secretaría privada. Durante su estadía en la capital, Valcárcel frecuenta los ámbitos intelectuales limeños, hospedándose en la casa de Riva Agüero, a quien había conocido en un viaje de éste último a Cusco. Durante los dos meses que permanece en Lima, Valcárcel recorre la ciudad y se reúne no sólo con Riva Agüero sino también con Víctor Andrés Belaúnde y con Manuel Vicente Villarán, entre otros, quienes lo vinculan a los más importantes diarios capitalinos, en los que logra publicar algunos artículos.

Una vez que Billinghurst accede a la Presidencia, luego de pactar con la fracción independiente de los civilistas, Valcárcel es designado Inspector Departamental de Instrucción, su primera experiencia en el Estado, que dura hasta 1914 (momento en que Billinghurst es derrocado por una conspiración liberal-civilista).

Otra importante experiencia política tradicional se produce hacia 1919 cuando, por la propuesta de importantes referentes del Partido Civil y del Partido Liberal, Valcárcel se postula como candidato a diputado por Chumbivilcas. Valcárcel mismo cuenta las vicisitudes de su campaña electoral, haciendo explícitas las prácticas "tradicionales" en las que se inscribe:

Una vez en Santo Tomás agasajé a los mayores contribuyentes, los agricultores más poderosos de la zona, a quienes llevé desde el Cusco regalos que pudieran serles de utilidad, como arneses, caronas, pellones y otros aperos que usa el jinete, así como también mucho de beber [...]. Al mes siguiente regresé a la segunda Asamblea de Contribuyentes, en la que se decidiría quién debía ser el triunfador. Volví a Chumbilvicas, llevando mucha cerveza y aguardiente [...]. Debía invitar a mis partidarios todo lo que podían comer y beber desde las seis de la mañana de un día determinado (Valcárcel, 1981: 201-202).

Y luego concluye:

Así se realizaban las elecciones en esa época, la campaña electoral consistía en asegurar lealtades, tratando de ser más obsequioso y amable que el contendor. Resulta evidente que

\footnotetext{
${ }^{34}$ Ver Botana (1985).
} 
no eran prácticas democráticas. Felizmente ahora son solamente anécdotas que, aunque nos pese, pertenecen a la historia de nuestro país (Valcárcel, 1981: 202).

Finalmente Valcárcel es electo diputado, pero ese mismo año Leguía toma el poder, dejando sin efecto el mandato de Valcárcel, por lo que éste pasa a la oposición cerrada a su régimen. Nótese que hacia 1919, mientras el movimiento anti-oligárquico ya va tomando consistencia, Valcárcel forma parte de ese mismo Estado que se está poniendo en cuestión. En 1930, cuando Leguía es derrocado por el comandante Luis M. Sánchez Cerro, Valcárcel es nombrado por éste Director del Museo Bolivariano de Lima, reincorporándose inmediatamente al Estado. Simultáneamente, con el cambio de gobierno Valcárcel logra acceder a una cátedra en la Universidad de San Marcos en Lima, y luego, por expresa orden de Sánchez Cerro, reemplaza en la dirección del Museo Arqueológico Nacional, al prestigioso arqueólogo Julio C. Tello, quien es retirado de esa institución por la fuerza (Valcárcel, 1981: 259-262).

Podemos sospechar que Valcárcel se suma a la oposición al Oncenio de Leguía desde posiciones oligárquicas que habían sido excluidas, pues más allá de su rechazo a los regímenes autoritarios, se enfrenta a Leguía porque - de acuerdo a sus palabras- "cerró toda posibilidad de compartir el poder con otros grupos políticos" (Valcárcel, 1981: 226), hecho observable en la persecución a los políticos tradicionales (como los civilistas), aunque también a los demócratas y liberales, dejando habilitado sólo al partido del gobierno. Recién en el campo de la oposición al Oncenio, Valcárcel empieza a vincularse con sectores radicalmente antioligárquicos, como apristas y socialistas. Así, en los años veinte aproxima dos visiones del mundo divergentes (tanto en lo epistemológico como en lo ideológico-político) en su propio discurso.

Como vimos, uno de los objetivos manifiestos del indigenismo de Valcárcel es suscitar sentimientos de afinidad para con el "indio". Sin embargo, cuando despliega su concepción de la alteridad indígena, no puede evitar la reactivación de los sentidos estigmatizadores del "otro" heredados de la tradición previa, y de la carga ideológica presente en los materiales epistemológicos con que se abordaba dicha otredad social. La idea de "tempestad", que articula todo el ensayo, repone una y otra vez las ideas de "barbarie", por remisión a las 
fuerzas irracionales de la naturaleza / de la masa, en contraste con respecto a la racionalidad moderna.

De ese modo, si bien Valcárcel asocia al indígena con el trabajo como valor clave de la modernidad y la modernización, y postula que la inferioridad del indio no responde a causas biológicas sino históricas y sociales, no logra (probablemente porque no quiere) remover totalmente la caracterización del indígena como individuo potencialmente peligroso. La representación positiva del "indio" quedará confinada al espacio cerrado de las comunidades aisladas. De ahí que, en Tempestad..., cada vez que el "indio" se halla fuera de estos grupos lejanos, emergen las diversas figuraciones del conflicto social. Además, en la visión de Valcárcel, cuando el indio empieza a superar su condición de inferioridad, al liberarse del régimen de opresión en el que está inmerso, logrando acercarse al sujeto occidental moderno - deseable, para el autor-, aumenta su peligrosidad a través del riesgo de una acción insurreccional (que puede, como una tempestad, no sólo arrasar la dominación latifundista, el centralismo y los elementos hispánicos -opuestos a la nueva concepción indigenista de la nación peruana-, sino también atentar contra la sociedad moderna y sus valores, especialmente contra la familia y la propiedad).

Ante esa voz de alarma, podemos sospechar que la postulación del indio como trabajador no se realiza para fomentar su emancipación en términos de clase sino, por el contrario, para integrarlo como factor productivo (en una sociedad que, por definirse en torno de lo indígena, no deja de concebirse -en el presente y en el futuro- en términos capitalistas y bajo el modelo tradicional de dominación de clase). Así, con un cariz liberal y reformista, Valcárcel no resuelve su indigenismo en socialismo. En este sentido, tal como veremos, el "lenguaje marxista" que encuentra Mariátegui en Tempestad... (en su "Prólogo" de 1927), probablemente intentando reconducir ideológicamente el discurso indigenista hacia la izquierda, resulta evidentemente problemático.

De ese modo, en el ensayo de Valcárcel la apelación a lo indígena -por añadidura, entendido como "lo inca"- resulta una alianza evasiva y meramente simbólica con lo subalterno, fuertemente ligada al proyecto de una intelectualidad regional que se propone alcanzar una legitimidad nacional, en oposición a las clases dirigentes centralistas de Lima. Por otro lado, la apelación a la revolución indígena fabrica un problema "a medida" para la intervención de los intelectuales indigenistas que se proponen como los únicos sujetos aptos para "encauzar" esas fuerzas indígenas integrándolas, de modo que no destruyan el carácter capitalista de la sociedad peruana. Nuevamente Ernesto Quesada lo expresa con claridad, cuando afirma que el papel que se le depara a "los hombres que dirigen [...] América" es 
"preparar el nacimiento de un nuevo ciclo cultural" de tal modo que - podemos agregar- no se trasciendan las premisas capitalistas del orden social.

Las formas autoritarias, paternalistas y violentas que propone Valcárcel para guiar a las masas indígenas, en las que se evidencia una fuerte desconfianza hacia lo subalterno, lo filian a una mentalidad política reformista, pero que no deja de tener fuertes continuidades con las prácticas políticas e intelectuales ligadas a la dominación oligárquica. Quizás la mayor novedad respecto de los intelectuales arielistas -además de la intención reivindicativa de lo indígena- sea la consideración de la democracia, la integración económica y social -en posiciones subalternas- y la reparación cultural, como un efectivo freno a la revolución socialista, fresca y potente en el imaginario social desde los sucesos de las revoluciones rusa y mexicana (ejerciendo esta última una particular incidencia entre las elites indigenistas peruanas, según advierte Majluf, 1994).

En síntesis, creemos que el discurso que Valcárcel construye en Tempestad... se comprende mejor en el ámbito de las pujas por la hegemonía en el interior del bloque dominante, donde la apelación a las masas indígenas funciona como una estrategia de indirecta auto-legitimación. De allí que, si bien se trata de una discursividad alternativa y/o divergente respecto de los intelectuales de la generación del novecientos, funciona con muy baja eficacia como ideología orgánica con respecto a los intereses de las clases subalternas. 


\section{Raza, indianidad y mestizaje en El nuevo indio de José Uriel García}

José Uriel García (1894-1965) es una de las figuras más resonantes del indigenismo peruano de los años veinte. Nace en un hogar humilde en San Sebastián, Cusco, en 1894, hijo de madre soltera. ${ }^{35}$ En 1908 ingresa a la carrera de Filosofía y Letras en la Universidad San Antonio Abad de su ciudad. Allí conoce a Luis E. Valcárcel, con quien serán compañeros de ruta por casi dos décadas. El autor de Tempestad en los Andes lo recuerda en sus Memorias como "un hombre muy sencillo y callado, con cierto recelo a la gente encopetada del Cusco". Como hemos señalado, la generación de García y Valcárcel, que cuenta con otros intelectuales reconocidos -como los hermanos Félix y José Gabriel Cosio, Luis Felipe Aguilar y José Ángel Escalante, entre otros-, fue la impulsora en 1909 de uno de los primeros movimientos de reforma universitaria del continente.

En 1911, García se gradúa de Doctor en Letras con la tesis "El arte inkaico en el Qosqo", donde aborda las manifestaciones artísticas y arquitectónicas incas en la región de Cusco. El interés por el arte no sólo está presente en su labor profesional, sino también en su vida cotidiana, ya que García es un músico aficionado, diestro en el manejo de diversos instrumentos. Ya graduado, da clases de Historia del Arte y de Filosofía en la universidad local, y realiza trabajos de investigación histórica y arqueológica, vinculándose con el emergente campo de la antropología nacional. Durante los años veinte se dedica también al periodismo, publicando con frecuencia artículos en el diario El Comercio, junto a otros de sus congéneres. En 1922 edita el libro Cuzco, la ciudad de los Incas, prologado por Valcárcel.

El nuevo indio. Ensayos indianistas sobre la sierra surperuana es escrito en 1928 y publicado por José Uriel García en Cusco, en 1930. El autor interviene en el debate

\footnotetext{
${ }^{35}$ Este dato fue provisto por Uriel García (1923-), hijo del indigenista cusqueño, en una entrevista concedida al autor en Lima en el mes de agosto de 2012.
} 
intelectual peruano a partir de la articulación creativa de tres afirmaciones que inauguran una nueva posición dentro del colectivo indigenista: que la nacionalidad reside en la sierra andina; que el sujeto más representativo de la esencia nacional es el mestizo (concebido como un "espíritu" o una "conciencia" y denominado "neoindio"), y que la puesta en marcha de un proceso de mestizaje cultural que modernice y unifique la nación depende de la creación de una cultura nacional, sobre la base del folclore y de la provisión de ideales para los sujetos populares mestizos, por parte de intelectuales que deben ser-ellos mismosrepresentativos de la nacionalidad (es decir, serranos, mestizos y de extracción popular).

Si el telurismo, ligado al regionalismo cusqueño -ideología que sostiene toda la operación intelectual de El nuevo indio-, y el elitismo arielista ya estaban presentes en el indigenismo de esa ciudad, la defensa del mestizaje y la afirmación normativa sobre la procedencia social de los intelectuales resultan una novedad, como también lo son la adhesión integral a posiciones espiritualistas y el rechazo categórico de la noción de raza.

\section{Un indigenismo afin al mestizaje}

El nuevo indio emprende una revisión de la historia de la zona serrana del sur de Perú. Mediante este despliegue el autor intenta demostrar que el mestizaje espiritual ha sido siempre -y continúa siendo- la dinámica a través de la cual se expresa la verdadera nacionalidad: "la sierra [...] es la realización en marcha del carácter nacional como resultado de una fusión de elementos contrapuestos" (García [1930] 1937: 180). La hipótesis que sostiene el autor es que el proceso de mestizaje ha sido, desde la conquista, el gran impulso modernizador de la zona andina; por ello, en consonancia con su punto de vista culturalista, el ensayista considera que las apuestas para la solución tanto del problema nacional como del problema indígena deben pasar por la conformación de sujetos mestizos, "nuevos indios", a partir de los valores estéticos y morales, forjados en la historia de la cultura mestiza y serrana, y que deben ser demarcados por el intelectual, así como también éste debe proveer "nobles idealidades" capaces de unificar la identidad nacional.

El ensayo desarrolla tópicos diversos que instalan los argumentos con los que García busca probar su hipótesis mestizófila, y legitimar su diagnóstico y su proyecto para Perú. El texto está articulado por una pregunta implícita, que intenta ser respondida a lo largo de las tres partes que componen el texto: ¿qué sujetos han encarnado históricamente la 
nacionalidad? O si se quiere, para un ensayo que tiene una voluntad programática: dada la experiencia histórica, ¿sobre qué sujetos representativos se debe encarar la tarea actual de unificación de la nación peruana?

El título de cada parte del ensayo funciona como una respuesta sintética a ese interrogante. La primera, titulada "El indio antiguo", comprende el período que va desde los comienzos de las culturas originarias hasta la conquista; la segunda, titulada "El nuevo indio", remite a la etapa colonial; la tercera, "El pueblo mestizo", aborda la salida de la colonia y el período republicano, hasta el presente de enunciación. Esos son para García los sujetos colectivos que han encarnado la nacionalidad en cada etapa histórica. Pero además, dada la fuerte impronta elitista del pensamiento de García, la pregunta por los sujetos representativos se articula con un interrogante -o en su reverso, una propuesta- sobre quiénes deben ser los líderes que guíen la reconfiguración de la nación. El "nuevo indio" será, al mismo tiempo, un modelo normativo de intelectual.

El ensayo combina, en su desarrollo, diferentes formas discursivas propias de la historia, la sociología de la religión, la psicología social y la etnografía folcórico-antropológica. No obstante, en su organización, ocupa un lugar privilegiado la enunciación que asume las características de un estudio de historia del arte. En efecto, en la búsqueda histórica de sujetos y líderes representativos -aptos, por ende, para encarar la empresa nacionalista-, García prioriza el análisis de las expresiones estéticas, ya que considera que en ellas se puede verificar, de manera privilegiada, la conexión entre el paisaje -como soporte de la nacionalidad-y la personalidad. Veamos un pasaje en donde se enuncia esta convicción teórica y metodológica que combina estética, psicología y telurismo, en una variante afín a la concepción de Valcárcel analizada en el capítulo anterior:

A primera vista se notará que la arquitectura tiahuanacota parangonada con la de los incas obedece a diverso impulso, a distinta "voluntad de forma"; tiene otro ritmo y otro gesto, interpreta singularmente su panorama propio en relación a la manera cómo se manifestó el hombre sumido en la tierra desgarrada de esta parte del señorío incaico. Si vamos a tomar en cuenta lo que proclama el pensamiento moderno, de que las manifestaciones artísticas, religiosas o de otro orden, están íntimamente vinculadas con el proceso interpretativo del mundo que las rodea (García [1930] 1932: 53).

Ese énfasis en la relevancia del arte (que, como veremos más adelante, va a ser propuesto como modelo para la construcción del "espíritu" o la cultura nacional) muestra una fuerte 
continuidad con la sensibilidad antipositivista del modernismo latinoamericano, que considera el arte como un instrumento de conocimiento superior con respecto a la verdad científica. García rechaza terminantemente la metodología positivista de conocimiento de la alteridad:

Para hablar de las "razas" quechua, aimara o kolla, yunga y salvaje o "anti" no hace falta comparar el índice facial, fijarse en el pigmento de la piel ni analizar los esqueletos. Labor minúscula la de los "antropólogos" y "etnógrafos" que hasta hoy no pueden decirnos una verdad rotunda sobre nuestro origen ni sobre nuestros parentescos colectivos o espirituales. Aunque tampoco hace falta./ En lugar de escalpelos y cronómetros será mejor sorprender el "alma" de estos paisajes sustentadores del hombre que en ellos nutre su afectividad y acrecienta su espíritu. Las cuatro "razas" no son más que cuatro espíritus (García [1930] 1937: 32).

Esta perspectiva se articula con una adscripción manifiesta a la propuesta de la antropología filosófica del alemán Max Scheller quien, situado en el terreno de la renovación filosófica emprendida por las "filosofías de la conciencia" vinculadas a Bergson y Husserl, prioriza el estudio del hombre y los agrupamientos humanos a partir del análisis de los fenómenos emotivos y los valores que los impulsan: deseos, voliciones, sentimientos e ideales (Terán, 2008: 198-201). ${ }^{36}$ En su ensayo, García busca esos elementos característicos de la espiritualidad serrana en la arquitectura y las manifestaciones plásticas, en la música, en las costumbres cotidianas (vivienda, vestido), en las prácticas religiosas, en las fiestas, e inclusive en la sociabilidad política. También los halla en algunas personalidades representativas, lo que coincide nuevamente con las premisas de Scheller, quien postula que los valores se condensan en tipos espirituales representativos que delimitan modelos morales. Así, el héroe encarna los valores vitales; el genio, los espirituales, y el santo, los religiosos. Ese análisis engarza con la mencionada convicción elitista acerca de la necesidad de que las "masas" -en la terminología de El nuevo indio, el "pueblo mestizo"- sean conducidas por una minoría, en este caso, del "ideal". ${ }^{37}$

\footnotetext{
${ }^{36}$ Como señala Terán (2008), la obra más influyente de Max Scheller es Die Stellung des Menschen im Kosmos de 1928, publicada por primera vez en castellano en 1929 en Madrid por la editorial Revista de Occidente (con traducción de José Gaos). José Uriel García no cita esta obra; introduce el nombre de Scheller en una nota que acompaña la mención del concepto "antropología filosófica" (García [1930] 1937: 52).

${ }^{37}$ La referencia explícita a Max Scheller no pretende soslayar la influencia de la tradición de pensamiento local que, desde Sarmiento hasta Ramos Mejía en Argentina, o García Calderón en Perú, ha analizado -aunque desde diferentes perspectivas teóricas y en períodos diversos- a "grandes hombres" como encarnaciones de una época o de las tendencias de las masas.
} 
Revisemos brevemente el contenido del texto, para aprehender mejor su organización formal y su estructura argumental. Esto nos permitirá abordar analíticamente algunos temas centrales en el ensayo: la dimensión epistemológica -en la que el pasaje del racialismo al culturalismo se combina con la apelación al telurismo-; la concepción del proceso de mestizaje, las representaciones del indígena y del mestizo y, finalmente, el proyecto intelectual que se recorta, implícitamente, en El nuevo indio.

El "prólogo" introduce la perspectiva epistemológica espiritualista de la cual García se vale para articular su discurso, y presenta sintéticamente los argumentos principales que luego se desarrollan en el ensayo. La primera parte, "El indio antiguo", analiza el período previo a la conquista. Allí el autor postula la idea -propia del telurismo- de que los espacios geográficos producen personalidades colectivas que encarnan, por identificación y apego espiritual, la esencia del lugar. En consecuencia, despliega un análisis sobre la personalidad colectiva más significativa durante la época precolombina: el "indio antiguo". Expresando la nacionalidad andina -que García denomina "indianidad"-, éste ha creado formas culturales religiosas, asociativas, consuetudinarias-, personalidades y formas artísticas. La personalidad y la cultura del "indio antiguo" adquieren modalidades diferentes según el área y el paisaje de la región andina que la contenga. No obstante, el ensayista afirma que las singularidades fueron luego sintetizadas en una mezcla superadora, operada por las "ideas rectoras" de los Incas, que son presentados por García como la primera élite dirigente que logró unificar y modernizar la región a través de un proceso de mestizaje espiritual.

La segunda parte, "El nuevo indio", se concentra en describir el proceso de mestizaje en el período colonial. Allí García desarrolla su tesis acerca de la emergencia de una "nueva conciencia" o "nuevo espíritu" mestizo, a partir del contacto entre españoles e indígenas en la sierra, que pasan a encarnar una esencia telúrica modificada por la penetración de la cultura occidental desde la conquista, y que el autor denomina "neoindianidad". García define las características de este proceso de mestizaje a partir del análisis del arte mestizo y de personalidades mestizas excepcionales. Allí nuevamente prioriza la focalización del arte, pues afirma que "el arte colonial representa la máxima ascensión de ese espíritu neoindio que germina desde la conquista" (García [1930] 1932: 122). Al mismo tiempo, lo eleva a la categoría de modelo de mestizaje deseable para crear un "espíritu" nacional, ya que postula que en él "la aptitud creadora de la voluntad indiana se apodera de las formas estéticas importadas, avasalla el espíritu invasor, se venga de su servidumbre y crea otras formas y otros valores de belleza plástica" (García [1930] 1932: 123). García afirma que es la 
religiosidad colonial, en la que "el sentimiento religioso de las Indias [...] se yuxtapone con los ritos católicos" (García [1930] 1932: 112), la institución que cumple la función de formación del "alma", el arte y la cultura mestizas, al hacer productiva -económica y culturalmente- la voluntad neoindiana en la colonia.

En ese nuevo contexto, el "indio histórico" ha dejado de ser representativo de la esencia nacional y, por ello, se ha convertido en un obstáculo para la modernización social. Así, para García a este sujeto social sólo le queda amestizarse o perecer, afirmación que evidencia una cierta concepción teleológica $-\mathrm{y}$ dialéctica- de la historia, por la cual las esencias se metamorfosean logrando una evolución espiritual, como encarnación del ideal de progreso.

Finalmente, la tercera parte aborda el pasaje de la colonia a la república en los pueblos y ciudades de la sierra, concibiendo a Cusco y sus alrededores como sinécdoque de toda la región. El período es señalado como una época signada por el caos, señalamiento que abre paso a una crítica a los intelectuales y las clases dirigentes desde la república hasta la actualidad. A estos sectores se les atribuye la responsabilidad del fracaso para dotar de un ideal ordenador a la neoindianidad y al "pueblo mestizo", desde la caída de la colonia. García plantea entonces la necesidad de un ideal que ordene la voluntad telúrica nacional, y como solución, propone apelar al regionalismo.

Simultáneamente, en el mismo apartado, García analiza la sociedad del Cusco actual. Para ello se apoya en una metodología que evoca tanto el relato etnográfico como la estetización de tipos sociales propia de la estética modernista ${ }^{38}$. El objetivo es demostrar que los sectores populares mestizos (esto es, sus expresiones artísticas, sus costumbres, sus valores históricos y sus ámbitos de sociabilidad) son los únicos que mantienen todavía contacto con la indianidad y que, por ello, conforman la cantera del folclore regional más apta para operar como base de una identidad capaz de unificar la nación, superando las diferencias regionales, pero sin obstaculizar la modernización social. Reforzando esta misma idea en otro plano, García también afirma que sólo los intelectuales mestizos y de origen popular pueden conducir los destinos de la nación hacia la unidad y la modernización.

\footnotetext{
${ }^{38}$ Es frecuente, en parte de la literatura modernista, la estetización de tipos y espacios sociales subalternos, des-realizando lo "real", ya sea desde una mirada populista que considera que lo subalterno desborda de belleza, o desde una perspectiva miserabilista para la cual lo subalterno es intolerable -por su precariedad, por su pobreza simbólica- y debe ser estetizado para volverse soportable. La estetización de lo subalterno opera como una mediación que permite saturar de connotaciones ideológicas al mundo popular, suscitando juicios de valor marcados por el preconcepto racial, ideológico, de género, de clase, que no se develan. Sobre la estetización de la pobreza en el Modernismo, ver Mailhe (2008).
} 
En el "Prólogo" de El nuevo indio García realiza una toma de posición epistemológica que enmarca toda la reflexión del ensayo. Como hemos adelantado, rechaza taxativamente los métodos, los diagnósticos y las soluciones a los problemas nacionales, propuestos por el racialismo positivista. Descarta el concepto de "raza" como factor explicativo de los agrupamientos humanos, y en cambio propone utilizar la noción de "espíritu", al tiempo que esboza un proyecto culturalista para la nación:

\begin{abstract}
Nuestra época ya no puede ser la del resurgimiento de las "razas" que en la Antigüedad crearon culturas originales, ni del predominio determinante de la sangre en el proceso del pensamiento y, por tanto, de la historia. Más bien parece que ya hemos llegado a la época del dominio del "Espíritu" sobre la Raza y sobre la sangre./ No será por la eugenesia, el cruzamiento y el cultivo fisiológico, únicamente, sino más que todo por la educación y el cultivo de las almas, por el intercambio de las ideas, por los grandes hechos de los hombres, que resurgirá entre los pueblos americanos una cultura valiosa y original./ El futuro es de los hombres de espíritu, antes que de los de riqueza nerviosa o de potencia muscular. Nuestro continente sufre más bien una plétora de vitalidad orgánica. Más que por el caudal de la sangre y la herencia fisiológica, la vida rindió siempre sus frutos más exaltados por el espíritu. La época de las razas terminó hace tiempo, porque esas razas eran espíritus cerrados, en ligamen íntimo con la circulación sanguínea (García [1930] 1937: 5).
\end{abstract}

Esa ruptura con el racialismo no está exenta de contradicciones, ambigüedades y recaídas, como puede observarse a primera vista en la terminología decadentista en la que se expresa, como "fin de una época” más que como una decisión epistemológica. El quiebre con el racialismo le permite reformular el diagnóstico sobre los males que aquejan a la nación: no son raciales, sino morales.

Ahora bien; García toma un camino singular para romper con el enfoque racialista, porque no desarticula las premisas del racialismo mediante una crítica epistemológica explícita. En este sentido, más bien da la sensación de que rompe "como puede" con los argumentos y las herramientas teóricas que tiene a mano. En el párrafo citado, como vimos, arguye que la noción de "raza" pertenece a una época pasada que ha sido superada por una nueva etapa en la que predomina el "espíritu". De manera conexa, cuando aborda el devenir histórico de los sujetos indígenas, señala, con criterio evolucionista, que en los primeros momentos de su existencia es la "raza", "la sangre", lo biológico, lo que determina los comportamientos, y que ese estadío racial, si bien tiene una íntima conexión con la esencia telúrica, es equivalente a un "espíritu cerrado" que se abrirá, volviéndose plástico, sólo en el 
marco del mestizaje. Esa condición "racial" no es apenas un momento histórico de una cadena evolutiva: además puede encontrarse en el presente, de modo residual, en la personalidad de los sujetos indígenas reacios al mestizaje y a la modernización.

Por otro lado, en su discurso, "raza" se asocia a "tradición", connotada negativamente ya que, para García, la tradición sólo se vuelve valiosa cuando se traduce en "valores morales para la cultura": "Sólo desde este aspecto puede ser el pasado también valioso. Cuando las ideas, los sentimientos y los grandes hechos de los hombres de ayer ingresen en el presente como imperativos morales, cuando ya no en la sangre sino en el espíritu se inyecten como riqueza social" (García [1930] 1937: 7).

Entonces, si lo distintivo de los seres humanos es ser un "espíritu”, la solución a los problemas de la región, la nación y el continente pasa por la educación y la provisión de ideales (tanto morales como estéticos) que modelen a esos sujetos, en sintonía con las ideas que, para el autor, pueden unificar y direccionar la sociedad hacia una meta deseable. García engloba esas tareas dentro del proyecto general de construcción de una cultura "valiosa y original" (esto es, moderna y nacional al mismo tiempo).

El énfasis espiritualista que hallamos en el ensayo ubica a García en continuidad con la tradición del modernismo arielista, representada en Perú por la ya abordada "generación del 900” que integran los hermanos Francisco y Ventura García Calderón, José de la Riva Agüero y Víctor Andrés Belaúnde, entre sus exponentes más conocidos. ${ }^{39}$ Tal como vimos en el capítulo II, estos intelectuales habían planteado soluciones espiritualistas a los problemas nacionales aunque, a diferencia del indigenismo cusqueño -que cambia el diagnóstico en favor de una clave cultural-, partían de un análisis heredero del racialismo positivista, al considerar la presencia de indios y negros como un obstáculo clave para el desarrollo nacional. No obstante, postulaban la posibilidad de un futuro promisorio para la nación y el continente, gracias a la expansión de una cultura de raíz latina, capaz de unificar y modernizar la región, sorteando el obstáculo que comportaba esa configuración racial negativa de las poblaciones americanas.

Así por ejemplo, en sintonía con esa clave de lectura, el tema de la construcción de la nación y la unidad nacional es recortado en El nuevo indio como un fenómeno de orden espiritual/cultural: "La sangre limita y separa; el espíritu unifica, funde y ondula por el universo./ La América de hoy es un conjunto de pueblos determinados, más que por la

\footnotetext{
${ }^{39}$ Al respecto ver Gonzáles (1996).
} 
sangre, por el espíritu. Sólo desde este punto de vista puede hablarse de nacionalidades" (García [1930] 1937: 7).

También de orden cultural es -como veremos en profundidad más adelante- la cuestión de la modernización social y económica. El ensayista convierte en modélico el efecto modernizador que tuvo, en el continente, la "Idea invasora", o sea, la cultura europea traída por los españoles luego de la conquista. Es más, para García incluso el "problema del indio" -tema central del discurso indigenista- es una cuestión netamente cultural:

El amestizamiento de América que genera un nuevo espíritu que avanza hacia el porvenir, trae consigo a su vez el grave problema de infundir en el indio esa alma juvenil y hacerle un nuevo indio total. $\mathrm{Y}$ en el caso singular de nuestra sierra surperuana, vasta zona de la indianidad, el problema de la cultura arrastra también el problema social de la redención del indio, problema que como bien dice José Carlos Mariátegui, afecta principalmente a las generaciones jóvenes de la sierra, pues es la cuestión regionalista por excelencia (García [1930] 1937: 110; cursivas en el original).

Esta particular resolución del "problema del indio", en base al desafío de convertir al indígena en un sujeto moderno, ubica a García en una posición singular entre los indigenistas peruanos, ya que su énfasis espiritualista/culturalista obtura casi totalmente las referencias a las dimensiones socio-económicas del poder y la dominación social, en la historia y en el presente peruanos. El párrafo arriba citado también permite desentrañar la concepción espiritualista del mestizaje que presenta el ensayo: como veremos, "amestizamiento" es el proceso cultural por el que se genera un "nuevo espíritu", "un nuevo tipo humano y cultural" (García [1930] 1937: 17).

\section{La concepción del mestizaje en El nuevo indio}

Ahora bien; para García, ¿cuáles son los elementos que se mezclan y en qué consiste dicho proceso? La inflexión espiritualista, en el modo de pensar la historia nacional, es determinante de la concepción del mestizo presente en El nuevo indio. El ensayista especifica su uso de este término, descartando su acepción racialista:

No nos referimos precisamente al mestizo fisiológico, sino al mestizo espiritual. Porque lo de menos es la cuestión sanguínea para todo aquello que se refiere al espíritu y no sea mero asunto de cruzamiento de sementales. El hombre, más que un reproductor, es una conciencia 
que al mezclarse se acrecienta en su fuerza creadora [...]. Lo "mestizo" no implica hibridismo como creen los seguidores del Dr. Gustavo Le Bon que califica de tales a los pueblos americanos (García [1930] 1937: 97; cursivas en el original).

Mestizo es entonces una conciencia acrecentada por la mezcla espiritual. ¿Pero cómo es la dinámica a través de la cual se ponen en contacto los elementos espirituales que se van a fundir? Para comenzar a responder esta pregunta, tomemos un párrafo que describe sintéticamente los procesos de mestizaje antes y después de la conquista:

[En los] llanos de clima específicamente templado vinieron a fundirse los elementos básicos de la nacionalidad originaria. El espacio histórico se llenó de vitalidad y en él realizaron los incas su dominio y sobre él movieron su Idea organizante, su disciplina encauzadora de la espontaneidad libérrima de las culturas primitivas [...]. Las llanadas serranas son los espacios humanizadores de los pueblos, los condensadores de la cultura. Manco Kápak, noble fruto de los llanos, convocó a los hombres de las cuatro partes del mundo andino a romper sus fronteras, a dejar sus parapetos aisladores y defensivos, a fundirse en la comprensión mutua y dar el poder máximo de su rendimiento espiritual [...]. Cosa igual ocurrió después del cataclismo de la conquista, cuando esos mismos pueblos que los incas iban soldando volvieron a la vida atómica, en fuga hacia sus cuevas puneñas o hacia la selva, en las fértiles explanadas interandinas se renovó la obra unificadora de la nacionalidad moderna, propiamente neoindia, por medio de los pueblos "mestizos", a donde regresan a renovarse las almas elementales del "cunti", del "anti" o del "kolla", almas que al fundirse con las nuevas ideas organizadoras del conquistador -en esta vez con más fuerza que antes- se amestizan, no ciertamente y en todo caso por la sangre, sino se compenetran y acreditan por el espíritu, se integran y perfeccionan, en cierto modo, porque el paisaje a su vez, está vitalmente acrecentado (García [1930] 1937: 40-41; cursivas en el original).

Para García -tal como puede apreciarse en este párrafo-, en los procesos de mestizaje que se dan en la sierra andina, antes y después de la conquista, intervienen cuatro elementos: el espacio geográfico, los habitantes, las ideas y los grandes hombres. Para el período previo a la conquista estos elementos son las zonas llanas de la sierra cusqueña, los "indios", las “ideas organizadoras de los incas", y "Manko Kápak” como el modelo de sujeto que encarna esas ideas, generando mestizaje espiritual. Para el momento de la conquista, en el proceso de mestizaje espiritual y de unificación nacional, el espacio privilegiado es nuevamente la llanura de la sierra de Cusco, pero además de los "indios", también participan los españoles; en esta oportunidad rigen las "nuevas ideas organizadoras del conquistador", que es el sujeto histórico de los comienzos del período "neoindio". Veamos entonces qué papel juega cada una de estas cuatro variables. 
El espacio geográfico como reservorio de la nacionalidad

La noción de "indianidad", central en el ensayo, se relaciona con una coordenada epistemológica fundamental del discurso mestizófilo de García: el telurismo. Esa matriz de pensamiento considera el paisaje como el factor determinante de los caracteres raciales y/o culturales de los grupos humanos que habitan ese espacio geográfico. En otras modulaciones clásicas producidas en la América Latina de la década del veinte, como por ejemplo en la obra de Ricardo Rojas, el telurismo postula que la esencia nacional arraiga en las fuerzas del territorio, y que el "indio", en tanto producto privilegiado de esas fuerzas a las que está sometido, es el más auténtico representante de la nacionalidad.

Esta tradición de pensamiento está fuertemente imbricada con los diversos regionalismos, tanto peruanos como continentales. En este caso, se halla orgánicamente ligada al nacionalismo regionalista y anti-centralista de Cusco, que postula a esa ciudad como la "verdadera" sede de la nacionalidad peruana, en oposición a Lima y a toda la región costeña, arguyendo su condición de antiguo centro civilizatorio de América. García reproduce este tópico regionalista cuando dice que

...la costa [es] un mundo de oposición a la entraña, porque en la costa triunfó el invasor, triunfó España, triunfó el emigrante; mientras que en la sierra no ocurrió lo mismo, pues el conquistador fue dominado por la tierra. En el Kollao o en el Cunstisuyu el alma hispánica se nacionalizaba, mientras que en la costa no, dominó su modalidad de inmigrante (García [1930] 1937: 50; cursivas en el original).

Para García la indianidad es una "energía vital”, una voluntad o una potencia que emana de la tierra de la sierra andina, "la región más india de América india"; y esa indianidad constituye la nacionalidad. En el razonamiento del autor, la sierra, al contener en su subsuelo la indianidad, nacionaliza todo elemento que sobre ella se pose; por eso "será siempre la entraña de la nacionalidad y de toda cultura original extraída de la tierra" (García [1930] 1937: 42).

Los ideales 
Tal como afirma Dalmaroni (2000: 2) para el caso de Ricardo Rojas, en El nuevo indio García propone un nacionalismo territorial para el cual la nacionalidad reside en la tierra y en el ideal. La referencia al caso de Rojas no es fortuita: la presencia de su pensamiento es perceptible a lo largo de todo El nuevo indio. García cita explícitamente Eurindia, y usa el neologismo del título, acuñado por Rojas, para designar el continente americano modificado por el mestizaje:

"Coloniaje" o "Virreynato" - cuestión de palabras-y, además, República, son, pues, épocas de formación en las que se realizó y va realizándose la indianidad moderna, la América personal o como la llama el pensador argentino Ricardo Rojas, Eurindia, o lo que el otro, Waldo Franz [sic], "Nuestra América” (García [1930] 1937: 106).

Para Dalmaroni, en la obra de Rojas el ideal, creado por la tierra, opera sobre ésta una vez que ha sido identificado y enarbolado por los líderes civilizadores. Del mismo modo, en el ensayo de García el ideal, provisto por minorías dirigentes vinculadas con la tierra -en base a un lazo afectivo-, modela y disciplina el caudal de energía, de potencia y de voluntad propias de la indianidad, encauzándolo hacia el mestizaje, lo que permite alcanzar metas sociales, morales y estéticas (que en El nuevo indio siempre están asociadas con la modernización social y cultural). En ese sentido, los incas son concebidos como la primera élite modernizadora que modela la indianidad a través de ciertas ideas, catalizando el mestizaje cultural que produce "civilización" (esta última, entendida como "progreso" y unidad nacional):

El incanato es el proceso civilizador, digamos tecnificante que va fundiendo las culturas regionales mediante las leyes, en una palabra, mediante el gobierno de los incas, representativos del espíritu moderno, que transita de la cultura prehistórica al progreso civilizador, del atomismo de los pueblos a la unificación nacional (García [1930] 1937: 17; cursivas en el original).

Así, García piensa una suerte de teleología universalizante, que se despliega desde la unificación incaica hasta la proyección actual y futura del modelo cultural gestado en la sierra, en base al mestizaje.

¿Pero en qué consisten las ideas provistas por los incas? García menciona "leyes", "gobierno", términos que pueden relacionarse con un valor normativo: 
La originalidad ejemplar del incanato es su obra política; es esa inteligencia ordenadora que hizo de las culturas espontáneas fuerzas que canalizaban la vida, dándole un sentido racional y armonioso./ El incanato es la pausa necesaria y fatal en la violencia creadora del alma indiana; el ritmo acompasado en la marcha precipitada. Fue el advenimiento de la norma que disciplina la voluntad libérrima y aislada, que sin ella no habría adquirido ese afinamiento comprensible y humano que llegaron a tener las culturas localistas de los señoríos regionales, sumidos, cada uno, en sus mundos excéntricos y cerrados, en sus hostiles linderos geomorales. El "Inca", para los pueblos autóctonos, tenía hasta cierto punto la fuerza dominadora de la idea platónica. Una Idea que conquista pueblos y los somete a su valor regulativo y autoritario, que conmina a los hombres a un trabajo de mayores rendimientos, que transforma la tradición en valores nuevos. La Idea cumbre, que como el nevero del confin, condensa la nube, la torna nieve, y, después, caudaloso río./ Lo incaico es, pues, la forma concreta y clara, definida al par que grandiosa, en que devino la "indianidad" (García [1930] 1937: 77).

En este párrafo aparece más claramente la inflexión regulativa de las ideas: ordenan, racionalizan, otorgan nuevos valores al "alma indiana" que se presenta como espontánea, caótica e incluso violenta, aunque también dotada de creatividad y de potencia. Las ideas disciplinan la voluntad, y por ello favorecen la fusión y la mezcla. ${ }^{40}$ Hay, además, una valoración positiva de las regulaciones autoritarias contenidas en lo que el autor denomina "la Idea incaica", que fuerza el aumento de la productividad del trabajo, y que "conquista" y "somete" de manera "grandiosa" (según la calificación del autor). Más adelante veremos cómo ese entusiasmo ante la eficacia de las regulaciones autoritarias, para revertir el caos de las culturas indígenas, también es proyectado por el ensayista para resolver los problemas nacionales. Pero ahora nos interesa remarcar, como se puede leer en el párrafo, que las ideas "dan forma" a la indianidad. En ese sentido, desde un parámetro afín a la idea de “civilización", García concibe lo incaico como el momento de mayor avance de la "indianidad primitiva".

"Indianidad primitiva" y "neoindianidad" son los dos "ciclos indianos" cuya diferencia reside en el hecho de ser performados por ideas e ideales diferentes. En base a esos períodos el autor recorta la historia peruana y continental. El primero comprende las culturas preincaicas y el régimen inca. Esa forma primitiva de la indianidad se interrumpe con el arribo de los conquistadores:

\footnotetext{
${ }^{40}$ En otros párrafos se despliega el mismo argumento. Por ejemplo, cuando señala que "la política incaica, bajo su férula, creaba ideas y formas regulativas del torrente espontáneo del alma antigua, de la sensibilidad copiosa del ayllu y al mismo tiempo incrementaba su volición, antes circunscrita a pequeños fines. La voluntad indiana, difusa, en los pequeños intereses del ayllu, necesitaba de la inteligencia normativa e incitadora de las acciones de largo alcance para cobrar mayor importancia histórica como llegó a adquirir bajo el gobierno de los incas" (García [1930] 1937: 26).
} 
Vino la conquista española y se deshizo esa forma, se apagó la lumbre ideal de aquella vida; la apoteosis del Héroe, como la de todos los héroes, fue la muerte. Tuvo fin la historia de los incas y con ella la vida incaica, que halló su tumba entre los escombros de la tragedia./ Mas lo inmortal fue sólo la indianidad, ese ligamen beligerante del hombre con la tierra, que no se perderá nunca mientras la tierra tenga esa fuerza incitadora de la acción eminente, del sentimiento torrentoso; en una palabra, mientras la tierra sea bárbara e indomeñable y sea formadora de hombres de igual temple espiritual (García [1930] 1937: 78).

En el período "neoindio", comienza "el proceso de la mezcla espiritual de América y del alumbramiento de una distinta voluntad indiana" (García, [1930] 1937: 90). Esta etapa se inicia con la conquista y se consolida durante la colonia, tomando luego un rumbo incierto durante la república.

A partir de la conquista ingresan al suelo americano ideas e ideales civilizatorios que, al arraigar en la tierra, dan nueva forma a la indianidad y la enriquecen. García pondera el efecto modernizador, no sólo espiritual sino también económico y social (en sentido capitalista), que tiene la cultura española al ingresar en el medio andino. Considera que produce un "agrandamiento telúrico de los Andes [que] aumenta su valor emotivo y económico" (García. [1930] 1937: 94). En efecto, la presencia española no sólo aporta "ideas, técnica y ciencia", sino que también da lugar a un exitoso modelo económico, presentado por el autor como una suerte de capitalismo de base colonial, que aumenta las zonas productivas, introduce el comercio y genera industrias regionales más prósperas que las de la república, y en las que "se realiza la educación técnica del indio y se desenvuelve su capacidad mecánica" (García [1930] 1937: 104):

La sierra colonial es un treno de esfuerzo fecundo que ha hecho la nacionalidad moderna./ Cada región de la sierra ha tenido su industria propia, su especialidad comercial. Así, Huamanga es hasta hoy célebre por sus esculturas en berenguela y por sus trabajos de "filigrana", Mamara por sus tejidos; Paucartambo, por sus tallistas y ebanistas; San Sebastián, por sus fábricas de tejas de arcilla, por la industria de la sal y por el cultivo de la linaza para el aceite de las iglesias; Canchis, por su alfarería; Quispicanchi, por sus obrajes y telares de lana, proveedores de todo el Sudperú; Arequipa, por sus viñedos y destiladores; el Kollao, por su producción agropecuaria; más allá del lago Titikaka, los muebles y cordobanes cochabambinos; el Cuzco, por sus bellas artes, casi como una industria especial (García [1930] 1937: 103-105).

Además, el español aporta ciertas características espirituales que renuevan la voluntad indiana, como "el individualismo, la religiosidad [y] el espíritu heroico" (García [1930] 1937: 88). 
García imprime una periodización centrada en el proceso de mestizaje, por sobre la periodización política de la historiografía tradicional. En esta dirección, la etapa republicana, iniciada con la Independencia, es concebida como un momento de desestabilización del período "neoindio", como consecuencia de la ruptura del orden logrado durante la colonia, principalmente en torno a la religión. Según la perspectiva del autor, la ausencia de un ideal unificador dispara la peligrosa posibilidad de que se produzca una disolución social que provoque un retorno hacia lo primitivo, que acecha encaramado no sólo en la cima de las montañas (adonde García considera que la modernidad no ha llegado) sino también, de modo residual, en la personalidad de todo serrano.

Frente este problema, abierto desde la República, el autor plantea la necesidad de intervención de los intelectuales, para lograr estabilizar el mestizaje, la modernización y la unidad nacional en torno a nuevos ideales regionalistas. En base a estas consideraciones, el texto se vincula con varios de los diagnósticos hegemónicos de la tradición ensayística heredada de entresiglos, sobre todo con la crítica a la "anarquía" generada por las revoluciones de independencia, tal como aparece por ejemplo en Las democracias latinas de América de García Calderón.

La mentalidad popular indiana y los "grandes hombres"

Para el ensayista, la mentalidad popular es reacia a las abstracciones; es supersticiosa, intuitiva y eminentemente emotiva. En sintonía con estos rasgos, en ella predomina una religiosidad con elementos residuales de la idolatría. García la califica inclusive de "primitiva" (García [1930] 1937: 55). El autor afirma que esas características son un rasgo distintivo y permanente en la forma popular de entender el mundo. Encuentra una perduración, a lo largo de la historia nacional, de la idolatría originaria de los "indios antiguos" para con los "Apus", elementos de la naturaleza andina concebidos como deidades, en particular las montañas, a tal punto que éstas adquieren el valor de "jefes viriles freudianos que reconfortan el miedo femenino de las multitudes" (García [1930] 1937: 12).

Ese sustrato se habría ido transfiriendo a otros sujetos sociales en los distintos períodos de la historia andina. Así como los Apus encarnan el "sentimiento localista", durante el régimen incaico la adoración "cesarista" del "Inca", en la figura de sus "grandes 
individualidades como Manco, Huiracocha, Pachacútek, Huaina-Kápak, Ollanta, Cauhide” (García [1930] 1937: 25) ayuda a promover la razón de estado incaica.

Del mismo modo, en el período colonial la religión católica genera, en los Andes, “cambios de equivalencias simbólicas" entre los íconos religiosos incaicos y la figura de los santos católicos populares, hecho que permite la expansión del catolicismo y, con él, la victoria definitiva de la conquista.

\section{De la religión a la política}

Ahora bien; el problema es que, con la secularización republicana, el sentimiento religioso popular es desplazado hacia el campo de la política: la antigua adoración se transfiere a los "caudillos demagógicos" y conservadores que interpelan el fanatismo popular con fines manipulatorios. Veamos, por ejemplo, el relato de este último tránsito:

[El] sentimiento religioso neoindiano, antidogmático, se encarna mejor en las muchedumbres republicanas. La plebe era sostenedora de la superstición y de la idolatría. Por eso la plebe es antes que democracia, demagogia y demagogos son los gobernantes republicanos. La demagogia se aviene con el fanatismo y los caudillos con la idolatría. Los caudillos políticos son tan sagrados como las santidades que cursan por las calles del pueblo para aplacar sequías y hambrunas, tanto como las santidades idolatradas por el vulgo son caudillos demagógicos en cuyo nombre se emprenden las "jornadas cívicas" o bajo su advocación se instalan las mesas electorales [...]. Ese es el éxito político de los caudillos que se yerguen aprovechando el fanatismo de las masas y llegando a ser afortunados gobernantes [...]. El pueblo republicano se ha apoderado de la dirección religiosa, es el que manda ahora, el que impone sus ritos, su iconolatría, su estética elemental y por eso el sentimiento religioso se ha trocado en fuerza tradicional, en emoción conservadora del pasado. Junto a las andas de los santos, lo mismo que junto a las mesas electorales, la tradición se defiende a fuerza de bala, de piedra o de garrote. La muchedumbre supersticiosa y fanática es reacia a asimilar toda forma de vida moderna, toda idea o sentimiento contrario a la costumbre, porque también los de "arriba" tienen interés en mantenerlo así (García [1930] 1937: 119-121). ${ }^{41}$

Tal como se percibe en este párrafo, García da cuenta de la efectividad de la dominación "cesarista" ejercida por los caudillos sobre lo popular indiano, al tiempo que la denuncia como un elemento conservador que implica un obstáculo para el arraigo de ideas y sentimientos modernos.

Como veremos, García intenta disputar el sustrato religioso cooptado por los líderes carismáticos conservadores, apelando a la cultura en tanto "creación del espíritu” (García

\footnotetext{
${ }^{41}$ Al respecto ver también García ([1930] 1937: 12, 27-28, 113-114).
} 
[1930] 1937: 7), y especialmente recurriendo al arte, como nueva vía para hacer arraigar ideales modernos en los sectores populares. Desde su punto de vista, el arte folcórico puede ser una interpelación efectiva para esa mentalidad imaginativa y sensible, característica de lo popular. Sin embargo, en convergencia con su elitismo insistente, el ensayista no deja de presentar modelos de individuos representativos, ni de postular la necesidad de formar sujetos "guías de la cultura", capaces de disputar la idolatría al caudillismo. En este sentido, el ensayo no escapa a una contradicción clave en la psicología de las multitudes de fines del siglo XIX (de La psicología de las multitudes de Gustave Le Bon a Los sertones de Euclides da Cunha o Las multitudes argentinas de José María Ramos Mejía): la figura del meneur se desdobla entre el líder peligroso (que establece un vínculo empático, irracional y retrógrado, con las masas) y el líder positivo (no casualmente identificado con el intelectual) que también debe interpelar a las masas apelando a su empatía afectiva (en este caso, por la vía del arte), para conducirlas hacia ideales elevados de progreso.

Bajo esta duplicidad descansa otra paradoja: García afirma una y otra vez que las ideas y/o los ideales encarnan en "grandes hombres" que operan como faros espirituales o guías de las almas. Esos individuos hacen arraigar las nuevas ideas en la mentalidad popular, pero a la vez ellos mismos son representativos del colectivo popular (lo que constituye una condición sine qua non de su dimensión de "grandes hombres"). Así, la figura del líder queda presa en la paradoja de la perduración de un orden arraigado en la larga duración, y el desencadenamiento de una transformación de ese orden.

\section{Dinámica de la dominación cultural}

Para García, desde la conquista se da una confrontación a muerte entre la cultura española, representativa de la civilización occidental, y la cultura inca (o en palabras del autor, "las formas en que se expresó el espíritu incaico -espíritu de la primera indianidad-como ideales de vida y de cultura"; García [1930] 1937: 78).

Esa dinámica opositiva recupera el pensamiento dualista presente en las lecturas canónicas de la dialéctica hegeliana, en las que el autor parece aplicar de modo general una concepción de la historia pensada como lucha: "El coloniaje es la historia de ese afán de apropiarse de la nueva tierra, tanto por parte del conquistador como por la del indio. Lucha tenaz que hasta hoy no ha terminado [...]; beligerancia por imprimir a la tierra la modalidad espiritual" (García [1930] 1937: 95). Y más adelante: "En cuanto se aproximan los dos 
elementos en lucha, el indio y el no indio -que tanto puede ser el español como cualquier otro hombre, sin sangre de indio- ingresan en la realidad histórica y el mundo, con su presente y porvenir" (García [1930] 1937: 98; cursivas en el original).

La radicalidad de esa confrontación es inclusive valorada positivamente por el autor, que desde una perspectiva vitalista afirma que "la contienda entre las dos voluntades engendró por toda la sierra dolor y odio, como elementos anímicos actores y positivos [...]; odio y dolor que perduran hasta ahora" (García [1930] 1937: 99). También tomemos nota, en esta cita, de la afirmación de que las luchas inherentes al proceso de mestizaje no han finalizado, llegando incluso hasta el presente de enunciación. Volveremos sobre esto más adelante.

Si bien, tal como vimos, en el marco general de la espiritualización del mestizaje, García subraya el carácter violento del enfrentamiento entre elementos culturales radicalmente antagónicos, especialmente en el contexto de la conquista, también advierte que se trata de un enfrentamiento entre fuerzas semejantes. De este modo, produce un borramiento de la asimetría implícita en las relaciones de dominación socio-cultural implicadas en ese proceso. Así por ejemplo señala que, a partir de la conquista, tiene lugar

...un brusco encuentro de dos culturas diametralmente opuestas [...]. La conquista es una catástrofe psicológica, como toda tragedia que nutre la historia de la humanidad. Para el espíritu indiano autóctono fue un cambio de derrotero, fatal, imprevisto, forzoso; todo un momento de prueba. Pero del mismo modo para la cultura invasora. Del percance salió el invasor con su integridad mermada por el influjo de dos elementos de capital importancia: la tierra y la tradición andinas; valores históricos ya constituidos en siglos de vida social./ La indianidad (no el incanato) estremecida vira su destino por otras rutas sin darse por vencida. Halla otras ideas o formas de expresión en que proseguir esa su juvenil y poderosa voluntad de genio andino. Por su parte, la vieja civilización española -síntesis de elementos heterogéneos- recibe otra inyección de la sabia vernácula y pierde, al mismo tiempo, su integridad histórica; inmersa en un medio que no era el suyo se produce de manera distinta a su cultura originaria (García [1930] 1937: 84-85; cursivas en el original).

Ahora bien, ¿cómo se modifican los espíritus que ingresan en la dinámica violenta del mestizaje? Si bien García afirma que, en el enfrentamiento espiritual / cultural por el cual se desenvuelve este proceso, se modifican ambos términos, en el análisis del texto se vuelve evidente que los aportes indígenas son prácticamente nulos mientras que, por el contrario, el polo español provee los elementos determinantes para la configuración del nuevo tipo espiritual. El español (cuyo carácter nacional aparece definido a partir de una amplia 
tradición ensayística previa y contemporánea, a partir de una occidentalidad ad hoc), se ve modificado sólo por el influjo de la esencia telúrica local, que cautiva su afectividad y lo nacionaliza (o, según la terminología del ensayo, lo "indianiza”):

Consumado el descubrimiento de América con la arribada de Colón, el nuevo elemento humano, y con él, su cultura, que desde entonces intervino en nuestros destinos, ingresó en [...] un escenario ya histórico donde iba a desarrollar el drama de su vida que a su vez prestaría escenario a otro carácter./ Esos Andes históricos, de valor impuesto por el alma indiana, envolvieron al español, sumergido dentro de sus contornos vitales y al mismo tiempo desenvolvieron en él una personalidad diversa a la que trajo al partir de España. El individualismo, la religiosidad, el espíritu heroico, todas esas virtudes y defectos que señala Blanco Fombona como características del conquistador español del siglo XVI, reaccionan o se desenvuelven de modo distinto ante los abismos o serranías del Cuntisuyu o de las anchas pampas kollavinas, que le acrecientan y le forman una conciencia histórica diversa (García [1930] 1937: 88).

Y luego:

El inmigrante español que penetra en los Andes con ánimo de fijarse para siempre ya no es un "extranjero", porque pierde su ligamen patrio y se arranca el nexo con su historia./ En las tierras cuya conquista le costó su audacia, su heroísmo, sus dolores y su victoria, por fin, se establece y en ellas liga su afecto y empieza para él su nueva historia [...]. Así pierde la personalidad española para tomar la personalidad indiana./ El indio, a su vez al tomar del conquistador sus ideas, su técnica, su ciencia y al penetrar en el panorama modificado forma otra tradición e inicia una nueva vida histórica. Transita por el espacio andino renovado como un emigrante (García [1930] 1937: 96).

En cambio, el polo indígena pierde sus características culturales; se vuelve permeable, plástico y absorbe los elementos espirituales del polo hispánico (al que se le asigna un papel modernizador ponderado por el autor). Lejos de toda posición de denuncia sobre el avasallamiento español durante la conquista, García valora positivamente la condición asimilativa de lo indígena, que el ensayista convierte en garantía de la aptitud de este actor para el desarrollo espiritual, y en indicador de su vitalidad. Por el contrario, condena toda resistencia al avance de las ideas occidentales. La celebración y la afirmación normativa, acerca de la necesidad de que los indígenas abandonen su tradición cultural y asimilen el acervo espiritual occidental, puede observarse con claridad en un pasaje en donde García confronta dos modelos de sujeto indígena en torno a las figuras de "Isabel Chimpu-Okllo" y "Kori-Okllo", mujeres de la realeza inca contemporáneas a la conquista: 
Isabel Chimpu-Okllo, nieta de Túpak Yupanqui, fue la madre de Garcilaso. Pero Isabel no es sólo la nieta de un inca ni la madre de un mestizo; es la tierra misma, son los Andes magnos, dentro de cuyas entrañas prolíficas se concibe la nacionalidad. Isabel es la contrafigura de esa otra india heroica, Kori-Okllo, como los Andes tienen sus zonas geográficas irreversibles y hasta hostiles. Tipos de mujer que representan tipos geográficos o naturaleza plasmadora. Aquella es la mujer dócil a servir de solaz amable en las horas de orfandad amorosa del conquistador; más que eso, la tierra fértil a todas las simientes, la historia que serenamente acepta su destino, el pasado que capitula vencido con Sairi Túpak, la América que se sobrepone a su tragedia. Isabel es la caverna americana que las mitologías indígenas llamaban "pakarinas" (lugares de advenimiento), de donde surgen otra vez los hacedores de la nueva cultura. De sus entrañas, como de esas grutas maravillosas de donde salieron los demiurgos incaicos, nace la barbarie mestiza que dará otro vigor al Continente. Mientras Kori-Okllo es la india bravía, hosca, reacia, como el despoblado de las punas cordilleranas, que no admite ninguna simiente extraña; la india que mantiene su alma virgen de pecado con otro que no sea de su raza, la tierra americana que queda como una reserva para otra conquista y para otra tragedia. Kori-Okllo es aquella india que se untó el cuerpo con estiércol y lodo y se dejó matar con saetas, atrincada a un árbol, antes que entregarse a la pasión sensual del invasor y concebir maternalmente la otra América -como lo hicieron Chimpu-Okllo, Beatriz Koya, Angelina Huailas Nusta, etc.-, en defensa infecunda de la tradición autóctona. Es la india que conserva su pureza cuaternaria, esa pureza que a su contacto todo retorna a lo primitivo, a lo milenario (García [1930] 1937: 142; cursivas nuestras).

De este modo, en una clara dialectización de los binarismos que intervienen en el mestizaje, Isabel Chimpu-Okllo representa un modelo moral que prescribe la aceptación serena de la derrota, permitiendo el avance del espíritu español y la emergencia de una nueva cultura; es, al igual que la tierra andina, un mero soporte para la modulación local de la modernidad occidental. Kori-Okllo, modelo negativo, atávico, personifica por el contrario la defensa inútil de la tradición incaica, que conduce a una regresión al primitivismo. La legitimación de la dominación, por parte del ensayista, queda implícita en la denuncia de la falta de sentido maternal, por parte de Kori-Okllo, como para concebir, metafóricamente, otra América, como resultado de la violencia sexual del varón conquistador. Esa falta de sentido maternal es aberrante desde la lógica patriarcal defendida por el texto.

De este modo, resulta evidente que, en el mestizaje "neoindio" propuesto por el ensayo, el polo hispánico-occidental es jerárquicamente superior, avanzado, moderno y “civilizatorio", tal como hemos señalado previamente.

Ese punto de vista nos permite colocar a García dentro de las miradas canónicas sobre el tema, que presentan un fuerte sesgo etnocéntrico. No hay indicios de coexistencia de elementos culturales o de heterogeneidad en el producto de la mezcla:

Los pueblos indios de hoy que han vuelto al primitivismo del ayllu prehistórico, se han liberado del incanato y han asimilado y mezclado con las suyas las costumbres posteriores a la 
hecatombe incaica; han adquirido o van adquiriendo cada vez más otra conciencia diversa a la que regulaba su acción en el "inkario". Nada del vigor indígena es supervivencia clara de la conciencia incaica, pues si así fuera el pueblo indio demostraría su falta de poder juvenil asimilativo o su ineptitud de crecimiento espiritual y merecería desaparecer de sobre la haz de la tierra o ir a confinarse a una "Arcadia incaica", como ese arcádico señorío de Vilcabamba (García [1930] 1937: 80).

Así, lo indígena incaico es rotulado como lo "tradicional". Es más, el borramiento de todo trazo de la cultura incaica no sólo es celebrado por García, sino que además es prescripto como un punto central del proyecto intelectual de El nuevo indio. En ese sentido, el mestizaje es, al mismo tiempo, el objeto de estudio histórico del ensayo y el proyecto modernizador impulsado por el autor.

El aporte de la tradición indígena sólo es considerado como positivo en el campo de la producción artística, como un "fondo inconsciente" para el folclore, dado que su cariz primitivo lo dota de "frescura" y "juventud", proveyéndole un "carácter original" a la cultura mestiza. En efecto, García valora el aporte indígena, en el arte mestizo o "neoindio", desde los parámetros de las vanguardias estéticas de la década del veinte, sugiriendo por momentos que el antecedente de esos movimientos se originó en la América colonial mestiza, en sintonía con las afiliaciones practicadas en general por los movimientos de vanguardia posteriores, con el Barroco como momento de clímax del mestizaje cultural:42

La plástica campesina tiene un valor de primer orden, precisamente por ese su carácter rudimentario, de estética elemental, por su frescura de fruto recién alumbrado [...]. Pintura que tiende a la deformación de las líneas y a la ingenuidad de la concepción, al colorido primario de vibrante intensidad [...]. El arte colonial neoindio [...] desde la conquista se apoderó de las formas y de las ideas occidentales, las simplificó a su manera, las primitivizó [...] y con ellas hizo un sentido estético propiamente americano (García [1937] 1930: 133, $135)$.

En el campo del arte, los aportes al mestizaje son más equitativos; incluso por momentos lo indígena se vuelve “dominante". El reconocimiento de la creatividad artística indígena se apoya entonces en un horizonte de expectativas modelado por las vanguardias estéticas contemporáneas a García, al tiempo que hace sistema con el reconocimiento de la

\footnotetext{
${ }^{42}$ Esa valoración de la potencialidad ultramoderna y sincrética del Barroco, desde las vanguardias, puede percibirse en los retornos al barroco por parte de numerosos ensayistas y escritores latinoamericanos (por ejemplo, por Fernando Ortiz y Alejo Carpentier en Cuba; por Ricardo Rojas y Bernardo Canal Feijóo en Argentina, o por Mário de Andrade en Brasil).
} 
idiosincrasia indígena como supuestamente más ligada a la sensibilidad, la exaltación de la imaginación y el misticismo. No sucede lo mismo en otras dimensiones -ciencia, técnica, ideales, moral-, donde el predominio es (y debe ser) netamente español. ${ }^{43}$ De modo privilegiado, García considera que es en el arte "neoindiano" de la colonia, y sobre todo en la arquitectura colonial, donde -retomando el lenguaje de la genética mendeliana- lo indígena se vuelve "dominante" y lo español "recesivo":

Bajo una doble modalidad se manifiesta la arquitectura colonial en sus valores estéticos. La primera, es aquella donde lo hispánico se impone sobre lo autóctono tradicional, de la misma manera como el conquistador sojuzga al indio. La otra, es esa donde la aptitud creadora de la voluntad indiana se apodera de las formas estéticas importadas, avasalla el espíritu invasor, se venga de su servidumbre y crea otras formas y otros valores de belleza plástica (García [1930] 1937: 123).

La arquitectura colonial es, para el autor, "genuinamente americana o neoindia". Allí se puede observar, en todo su esplendor, el "barroco americano", término que el ensayista recupera a partir de una obra, citada en el ensayo, titulada Fusión hispano-indígena en la arquitectura colonial (1925) de Ángel Guido, intelectual argentino cercano a Rojas, que teoriza sobre la "fusión hispano-incaica" que se da en torno a la presencia del arte barroco español del siglo XVI en el continente americano, y que incorpora el concepto de "Eurindia" tomado de Rojas, para dar cuenta de ese mestizaje modélico. Para García, "el barroco del Seiscientos español, importado a América, se mezcló con las formas decorativas del arte autóctono y al fusionarse produjo un barroco americano" (García [1930] 1937: 124; cursivas en el original). Este arte es, para García, el mejor producto del mestizaje colonial, porque expresa el "espíritu neoindiano", su aptitud creadora, su voluntad, su forma de ver el mundo. Es por ello un modelo privilegiado de mezcla espiritual.

Anclada en una larga tradición latinoamericana, ${ }^{44}$ la apelación a la arquitectura que propone García, para alegorizar el mestizaje, constituye un recurso especialmente cómodo para un arqueólogo e historiador del arte; además le permite exhibir un conocimiento profundo de las obras, reforzando la legitimación de su propia autoridad intelectual. No es un

\footnotetext{
${ }^{43}$ La misma jerarquización de las diversas áreas culturales hace Manuel Gamio, al modelar el indigenismo del siglo XX en Forjando patria (1916).

${ }^{44}$ Ver por ejemplo el papel simbólico de los arcos triunfales en el Barroco de la Nueva España (en el análisis de Octavio Paz en Sor Juana Inés de la Cruz o las trampas de la fe (1982), o el papel asignado al templo del arte en el final de Eurindia, como encarnación material del mestizaje espiritual americano. Al respecto ver Mailhe (2017).
} 
dato menor que, entre las obras arquitectónicas de la colonia, sea el templo católico colonial, en la sierra, la obra que el autor considera como más representativa de esa fusión espiritual. A la vez, la visualidad y la alegoría de esa arquitectura, permite modelar los ideales (estéticos, culturales, políticos) de las masas, e incluso de las élites, con más facilidad que otros lenguajes.

Esta metáfora arquitectónica del mestizaje nos permite identificar nuevamente a García con el pensamiento de Ricardo Rojas, vínculo que se vuelve manifiesto en la correspondencia entre ambos, en la que el autor de El nuevo indio ubica a Rojas en el lugar de "Maestro" e inspirador de su obra (Mailhe: 2017). Según Gorelik (2001: 302), es Rojas quien difunde en Eurindia (1922) el programa del movimiento neocolonial, que busca en las fuentes interiores de la cultura continental las bases para una renovación estética que no necesariamente comparte un ánimo vanguardista. Este movimiento tiene un importante arraigo en la arquitectura y las artes decorativas en la América Latina de los años veinte. ${ }^{45}$ Algunas de sus obras más destacadas pertenecen a Ángel Guido. Su propuesta de estilización de motivos indígenas es una de las claves del éxito del Art Decó en América Latina. Para Gorelik (2001: 302), el movimiento neocolonial representa un regionalismo exacerbado, que nace de la voluntad de oponerse - de manera radical- al "exotismo" de la metrópoli cosmopolita, a tal punto que desemboca en la reivindicación del arte barroco del Alto Perú.

La religión católica es valorada por García porque logra transmitir eficientemente sus ideas e ideales a través de la simbología indígena, llegando a modificar $-\mathrm{o}$ a modernizar, si se quiere- la mentalidad primitiva de lo popular indiano, a partir de significantes consustanciados con el espíritu local (y por ende, originales y nacionales). Los significantes tradicionales de la mentalidad indígena se resemantizan, cargándose de connotaciones propias del espíritu occidental. Pero ese pasaje por la forma indígena disloca a su vez la religiosidad católica, que se funde con el sentimiento religioso $-\mathrm{y}$ animista- del paisaje, expresando una "emoción solamente americana por medio de ese lenguaje de formas y de símbolos que el paisaje neoandino se expresa sobre la piedra de las murallas" (García [1930] 1937: 130). Como veremos, en su programa García postula que el arte folclórico es el posible reemplazo de la religión, basándose en la confianza en que puede comunicar

\footnotetext{
${ }^{45}$ Gorelik (2001: 301) afirma que las artes decorativas ocupan un lugar importante en el Modernismo de nuestro continente, ya que se les atribuye la capacidad de mezclar todas las técnicas, superando la fragmentación de la experiencia estética operada por el canon clásico que separa las disciplinas.
} 
eficientemente los nuevos ideales modernos, valiéndose de los mismos significantes históricos de lo local.

Más aún, García advierte que lo indígena "avasalla" el espíritu español y se "venga" de la servidumbre, al crear otros valores de belleza plástica. Así retoma la idea de confrontación que, no obstante, se suaviza, en el caso de este mestizaje modélico. La importancia otorgada al orden espiritual, al que se le concede un efecto reparador sobre la dominación económica, social y política del indígena en la colonia, se vincula nuevamente con la sensibilidad del espiritualismo modernista, que da prioridad a la cultura por sobre las otras esferas de lo social, y le asigna al arte y al artista un lugar rector en la sociedad.

Esa mirada resulta cómoda para apagar la gravitación de las cuestiones referidas a la dominación y la subalternidad, así como para generar una ficción sobre la incorporación de lo subalterno mediante la inclusión de elementos espirituales/culturales. Esto se hace patente a través de la metáfora arquitectónica. Se destaca la participación del indígena en las obras coloniales, pero esa participación está muy por debajo de la tarea intelectual, que crea idealmente la obra y luego la transmite a los trabajadores (incapaces de crear ellos mismos un producto de semejante complejidad).

El aporte indígena que García reconoce se concentra en los aspectos decorativos del edificio: introduce en la obra arquitectónica elementos de la cosmovisión indígena del mundo, como un mero acento en la estructura de base hispano-colonial. La "indiátide" -sustitución de la cariátide helénica-, el capitel y la columnas adornadas con flores, frutas y animales propios de la sierra, y los motivos astrales y otros símbolos mitológicos andinos, conforman una "decoración donde el panorama andino se ha plasmado [dando] una expresión que no puede ser más autóctona, más original ni más americana” y que refleja, para el autor, la emoción y la voluntad creadora neoindiana (García [1930] 1937: 129). Esto es considerado por García como una fuente positiva de "originalidad", otro valor de la constelación modernista, que viene a demostrar el carácter promisorio de la nueva cultura, plena de voluntad.

Ahora bien; para García, ¿en qué consiste esa originalidad? En un dislocamiento respecto de la forma occidental que, no obstante, supone una mera simplificación:

Esa médula de la espiritualidad americana que llamamos alma indiana elementalizó los medios de cultura ofrecidos por el conquistador, se apoderó de ellos, vertió su emoción y los redujo a valores simples y con ellos dio una expresión distinta a la plástica que se conoce por colonial (García [1930] 1937: 125). 
García exalta el valor de lo simple, argumentando que "disloca la técnica clasicista" y escapa al canon de la "unidad, variedad y armonía", en sintonía con la operación estética de las vanguardias primitivistas, como un indicio de juventud, vitalidad, y potencia. No obstante, sigue resultando difícil encontrar algún aporte sustantivo a la mezcla, por lo que lo "simple" no llega a trascender su tradicional asociación con la pobreza discursiva. Al mismo tiempo, queda claro que, retomando la metáfora que nos ocupa, el "arquitecto" -nuevamente, el artista- del mestizaje pertenece al espíritu español/occidental, que diseña integralmente la obra en torno a la religiosidad católica; la plasma idealmente en el plano, y dirige la construcción valiéndose de la técnica y la ciencia occidentales. De ese modo, la metáfora arquitectónica del mestizaje relega lo indígena, más allá de su exacerbación retórica, a la subalternidad: como mera fuerza de trabajo y como pincelada decorativa. Como veremos, lo subalterno ocupa un lugar análogo en el proyecto social de El nuevo indio.

\section{Diagnóstico intelectual: el mestizaje en peligro}

En la organización argumental de El nuevo indio, el análisis del mestizaje en la historia de la región conduce a un diagnóstico de los problemas actuales y a la enunciación de un proyecto de país futuro que permita lograr la unidad y la modernización de la nación. Como ya hemos adelantado, ese proyecto tiene, como punto central, la profundización del mestizaje espiritual a partir de la creación y difusión de una cultura nacional anclada en el folclore mestizo de la sierra, y articulada con el ideal regionalista que deben proveer intelectuales cusqueños, mestizos y de extracción popular.

La necesidad de intervención de los intelectuales es planteada en torno a la afirmación de que el proceso de mestizaje se encuentra desestabilizado desde la ruptura del orden colonial. García le atribuye la responsabilidad a las clases dominantes, que por conveniencia buscan el predominio de la tradición cultural del "indio antiguo", con el objetivo de facilitar su cooptación en pos del mantenimiento de un orden social conservador, dejando como saldo el fracaso moral y económico de la región. García invierte la patologización de lo popular, presente en los diagnósticos del pesimismo racial de entresiglos, y lo redirecciona hacia las clases dominantes, a las que les atribuye la responsabilidad por los males nacionales, tal 
como puede observarse cuando compara los ámbitos de sociabilidad subalterna y los de las clases dominantes:

\begin{abstract}
¿Qué es, pues, la chichería serrana? El lecho de alumbramiento del alma popular, la gruta de donde surge el eoántropo de la cultura del porvenir [...]. Esta cueva, donde se revela lo espontáneo y elemental, como la imagen fotográfica en la cámara obscura, es más valiosa para la nacionalidad que una cantina confortable o que una sala de juego de club, por ejemplo, porque allí el antropoide ya es un simulador disfrazado de guantes y vestido a la moda. Aquí sí vive ese "pueblo enfermo" admirablemente descrito por el escritor boliviano Alcides Arguedas, mora el hombre desnacionalizado, porque en la cantina o en el garito, que también son cavernas, la palabra soez, el chiste malévolo y tendencioso, la murmuración o el insulto canallesco, que recorren silbando por la sala llena de tapicerías de felpa, entre la atmósfera saturada del vaho del champaña o de la fragancia de los perfumes artificiales, ya no son el grito de lo espontáneo y elemental, sino la ponzoña del fracasado, del hombre sin personalidad. Mientras que allá hay creación y advenimiento rudimentario, aquí es la muerte y el espectro. Ya no es el pueblo mestizo creador de lo nacional, sino la clase social de todas las latitudes como de todos los tiempos. Entonces, el mal no está abajo, sino arriba (García [1930] 1937: 172-173).
\end{abstract}

Los sectores populares mestizos son relevados de toda responsabilidad en la situación actual ya que, desde la perspectiva elitista del autor, su comportamiento depende siempre de las ideas que les proponen los sujetos que los conducen. Por eso pueden ser "tumulto" bajo la dirección de las élites conservadoras, o "sujetos de la acción futura" bajo el ideal regionalista que propone El nuevo indio. La confianza en el "pueblo mestizo" como sujeto del cambio social ubica a García en una posición particular dentro de la constelación de los indigenismos peruanos de los años veinte. Veamos cómo expresa el autor su mestizofilia, en un párrafo donde es posible intuir, en la metáfora del descenso-ascenso, la influencia del indigenismo mexicano, encarnado en la obra del antropólogo Manuel Gamio, ideólogo importante del mestizaje hispano-indígena inmediatamente precedente: ${ }^{46}$

El "mestizo" [...] es el sujeto en quien se expresa, por ahora, balbuciente, el espíritu neoindiano. Conciencia o zona espiritual donde el indio que viene del pasado milenario [...] se eleva hacia la complejidad y hacia los problemas de otro régimen de vida, de inquietud, de esperanzas, así como el otro que surge del mar se torna elemental y hasta bárbaro, para luego volver a ascender como todo un americano.../ El alma mestiza, es pues, pese al descrédito del término, el comienzo del americanismo total [...]. Es el alma que infunde vida a la América actual (García [1930] 1937: 107-108).

\footnotetext{
${ }^{46}$ Para un abordaje de algunos aspectos de la obra y la biografía intelectual de Manuel Gamio ver De la Peña (2006), Rutsch (2007) y Kouri (2010).
} 
De ese modo, en el discurso de García, el "cholo" o mestizo desplaza al indígena y su cultura como significantes de lo nacional, y también como el sujeto en torno al cual desarrollar el proyecto de reconfiguración de la nación peruana, contradiciendo así toda la tradición indigenista afiliada al pensamiento de Manuel González Prada. Sin embargo, una característica distintiva del ensayo, y que le confiere cierta complejidad, es que el autor no se limita a utilizar las nociones de "mestizaje" y "mestizo" para designar el proceso y el producto de la mezcla espiritual que considera representativa de la nacionalidad moderna. Probablemente con el objetivo de reforzar su adscripción al movimiento indigenista, se apropia del concepto de "indio", para conectarlo deliberadamente con su programa de mestizaje cultural. Tal es así que llama "indio" o "neoindio" -y en menor medida, "mestizo" y "cholo"- al sujeto producido por la mezcla espiritual, e "indianización" o "neoindianización" al proceso de mezcla. Al mismo tiempo, restringe el alcance del concepto de "indio" de tal modo que excluya lo que denomina "indio antiguo", "histórico" o "tradicional", asociado con las comunidades indígenas, con el ayllu (el cual, como veremos, mantiene decididamente al margen de la formación del "nuevo tipo espiritual" americano). Así, en el ensayo, "indio" o "nuevo indio" nunca remiten al indígena stricto sensu.

\section{La amenaza de la tradición indígena}

A pesar de que por momentos el ensayo se solidariza con la situación de subalternidad del indígena, paradójicamente, asume en última instancia un sesgo antiindígena. García parte de la afirmación de que el proceso de mestizaje todavía no ha concluido. Se mantiene -dice el autor- "en ese instante de alborada, en ese estado de la promesa o de la esperanza, sin que tampoco la agonía del indio antiguo concluya de una vez" (García [1930] 1937: 141). El mestizaje se encuentra en riesgo, amenazado por la influencia arcaica del sustrato cultural indígena tradicional, que obstaculiza el avance de la cultura moderna mestizo-europea, con el agravante de la intervención de los intelectuales tradicionalistas, que intentan proponer el "inkario" como ideal de vida y de cultura para la nacionalidad en construcción. García señala el riesgo de un mestizaje en el que predominen los elementos de la "indianidad primitiva [...] que fugó, destruido el incanato, a las cavernas milenarias y desde allí acecha" (García [1930] 1937: 82; cursivas nuestras). Y más adelante advierte: 
Si el espíritu en germen que [el mestizo] tiene dentro tuviera que volver a la tradición incanista solamente, se tornaría en un hombre arqueológico y envejecido, como ese Matusalén que es el indio-incaico de los ayllus centrífugos, que superviven en las eminencias andinas como espectros del pasado, del mismo modo que si tornase a la tradición española únicamente no pasaría del servilismo imitativo. Porque ya se ha visto que el indio que se torna mestizo vuelve a adquirir su energía primitiva, la frescura juvenil de su barbarie, lo que no es posible manteniéndose en su tiempo y su modalidad incaicos, porque dentro de su incanismo viene a resultar el hombre que alcanzó para siempre su madurez y su perfección final (García [1930] 1937: 145; cursivas en el original).

El indígena es concebido como un residuo del pasado que permanece en una temporalidad propia de la "indianidad primitiva", reacio al mestizaje, y que por ello acaba siendo recortado -como en las teorías racialistas previas- como un obstáculo para la modernización cultural y social. Para el ensayista, el hecho de que el indígena se encuentre en un tiempo histórico “incaico", remoto, determina el predominio, en él, de lo biológico por sobre lo espiritual: "el indio antiguo, hoy, es más sangre que espíritu” afirma García ([1930] 1937: 6; cursivas en el original). Esa aseveración implica la reposición de la mirada racialista con la cual el texto pretendía romper. Como podemos apreciar, esa perspectiva es proyectada sobre el indígena que se ha mantenido al margen del mestizaje, figura que se contrapone polarmente a la del mestizo:

El pueblo mestizo, ese "poblacho mestizo" que despectivamente denigran los incomprensivos de la verdadera nacionalidad, es el que, a pesar de todo, forma el alma de nuestros pueblos y nutre de emoción nuestro sentimiento de americanos. Y en esta beligerancia cruenta de las pasiones lugareñas, el único que ocupa la zona neutral, escondido en su cabaña o en la caverna de su poncho o de la chichería, es el indio, el "alma muerta", la carroña de la explotación. Esa es su desgracia, la apatía pasional de que padece, su mansedumbre de rebaño. Por eso es el único causante de su miseria (García [1930] 1937: 161).

\section{Y también:}

El indio que se aleja [del mestizaje] es el "alma muerta", el mitayo, el yanacona, el siervo de encomienda. Es el ayllu que se vuelve a encaramar a su montaña, cultivando su parcela, que apenas le sostiene, como a una planta la tierra indispensable que alimenta la raíz, de espaldas al camino que conduce hacia horizontes más amplios./ Mas el indio que asoma con audacia a la dolorosa realidad y la afronta serenamente es el que vuelve a domar la piedra de las catedrales, el que acepta la nueva Idea y la expresa con otra emoción, el que reconquista la tierra con voluntad directiva (García [1930] 1937: 98). 
En esta área del ensayo, las concepciones del indígena se vuelven radicalmente negativas, haciendo emerger una mirada despiadadamente devaluadora. El indio es representado como un ser temeroso, falto de voluntad, sin vitalidad ni pasión, inmóvil y débil como la vegetación de las alturas. Se le niega humanidad - espiritualidad, en los términos del ensayoal consignarlo como un "alma muerta". El autor llega en estos párrafos a atribuirle, en base a esos rasgos, la razón de su subalternidad, su condición de oprimido. De ese modo, García omite todo análisis de las determinaciones históricas y sociales de su explotación.

Hay también, complementariamente, una concepción negativa del ayllu, de la comunidad indígena, espacio sobre el que el autor recorta un "área cultural" bien delimitada, resistente al avance de una modernidad que se ha tenido que abrir paso violentamente, dándole muerte para poder penetrar en ese espacio:

Comunismo de las hormigas, de mero instinto, de fraternidad primitiva, claro está, fresca y vigorosa como todo lo primitivo. Pero a seguir esta vida del ayllu sin las oposiciones y violencias de los pueblos que destruyeron los primeros imperios y después el incanato, la cultura que germinaba se habría secado y la vida paradisíaca del ayllu, según los imaginativos fervorosos del pasado, habría sido, como continúa siendo todavía actualmente en algunos ayllus milenarios y antihistóricos, el paraíso que debe ser la vida de las hormigas o de las abejas ¡Si fuéramos solamente hormigas o abejas! (García [1930] 1937: 24).

El autor le atribuye al ayllu un modo de organización social comunista, para defenestrar en conjunto ambos términos. Uno y otro son asociados a una sociabilidad arcaica, propia de una animalidad elemental, instintiva, sin historia ni cultura, representada por la figura del insecto, cuya eliminación es celebrada. Es importante destacar que García afirma que esa sociabilidad indígena "continúa [...] todavía actualmente en algunos ayllus" y que, por contigüidad, podemos suponer que el ensayista también prescribe su combate, ni más ni menos que como a una plaga que, de lo contrario, puede "secar" la cultura mestiza que "germina".

De ese modo, el ensayo va tomando entre líneas una posición afín a la eliminación de la tradición cultural indígena o, al menos, a su exclusión respecto de la identidad cultural mestiza que pretende fundar como eje de la nacionalidad renovada. Allí podemos intuir una manifestación de temor ante algún posible "desborde racial”, y una toma de posición, por momentos reaccionaria, frente a hechos tales como los levantamientos de indígenas, 
ocurridos en los departamentos de la zona serrana del sur de Perú, durante los años veinte, asumiendo así una perspectiva cercana a las narrativas de los gamonales. ${ }^{47}$

Pero esta posición en sordina coexiste con una propuesta explícita en favor de estabilizar el mestizaje que, como venimos adelantando, apunta a la construcción de una cultura nacional que abreve en el folclore serrano. Ahora bien, ¿de qué modo considera García que esa cultura logrará que la dinámica del mestizaje se estabilice y consolide, forjando sujetos modernos, identificados con la nacionalidad propuesta, y que contribuyan a la unidad y a la modernización del país?

\section{La formación de una cultura nacional mestiza:}

de la política a una cultura artística de base folclórica

Para definir el proyecto cultural de El nuevo indio, una primera cuestión a señalar es que el ensayista despliega una imaginación folclórica de corte etnográfico, distante del folclorismo neorromántico-conservador de entresiglos, preocupado por rescatar un patrimonio histórico condenado a una irremediable extinción. ${ }^{48}$ Lejos de la recolección de mitos y leyendas más arcaicos, que García asocia con posiciones tradicionalistas, los materiales folclóricos que privilegia, para la construcción de la nueva cultura, refieren todos a una sociabilidad popular pensada como continuidad respecto de la colonia. Frente a este legado, el autor se ubica simultáneamente en el lugar de observador y de nativo, remarcando su conocimiento y su pertenencia al universo popular. Acorde con ello, reconstruye el uso de los espacios urbanos por parte de los sujetos mestizos: en pueblos, aldeas y barrios populares de Cusco, menciona lugares de culto y de esparcimiento (como la parroquia y la chichería, respectivamente), así como también las viviendas populares. Además de los ritos religiosos y las fiestas, García analiza las artes -música, pintura y escultura-y la vestimenta popular del poncho, el chullu y el chumpi. Llega incluso a indagar el comportamiento de la mujer mestiza -"la chola"-, y hasta las costumbres sexuales populares. En ese inventario de prácticas, espacios y objetos

\footnotetext{
${ }^{47}$ Tal como vimos en el apartado "El retorno de la peligrosidad indígena: ceder algo para no perderlo todo" en el capítulo II de esta tesis.

${ }^{48}$ En este tema tomamos, como modelo, los trabajos de Gorelik (2001) y Farberman (2010), que analizan la imaginación etnográfica de algunos intelectuales del interior argentino en la década del veinte, tales como Ricardo Rojas, Bernardo Canal Feijóo y Orestes Di Lullo.
} 
entre los que se delimita su definición del folclore, García encuentra los materiales necesarios como para forjar la nueva cultura nacional.

Para García, el folclore nacionaliza y genera mestizaje, forma "nuevos indios", al engendrar sentimientos, emociones y estados anímicos comunes, sobre los que se articula esa "entidad psicológica" al mismo tiempo nacional y popular. Veamos:

El huaino, como las otras formas de la cultura folklórica, nacionaliza, es raíz afectiva que sujeta al hombre al agro patrio y al recuerdo de los antepasados. Medio afectivo que suelda al indio antiguo o tradicional con el mestizo y el blanco -en cuanto estos últimos están sustentados también por el sentimiento andino. Mejor dicho, mediante el huaino el indio retrae hacia sí el espíritu vernacular que avanza, y entonces, los tres elementos étnicos se funden en una entidad psicológica que sustenta el alma del pueblo o del serrano -punto de arranque del sentimiento neoindidano [...]. A su vez, el huaino del pueblo mestizo suspende al indio tradicional hacia su nivel emotivo y le invita a marchar hacia el futuro, de acuerdo con la fatalidad de su destino. De ese modo el huaino, lo mismo que el arte u otra forma de cultura, es un punto de encuentro que fusiona dos jerarquías espirituales de nuestros pueblos (García [1930] 1937: 75, cursivas en el original).

La cultura folclórica nacionaliza porque genera afectividad hacia el paisaje y la tradición histórica, y al mismo tiempo moderniza. Al proveer sentimientos comunes establece puntos de contacto entre el "indio antiguo", el mestizo y el "blanco", posibilitando la fusión en una nueva conciencia integradora.

¿Cómo se da esa fusión? El arte folclórico genera el mismo movimiento dialéctico que se le atribuye al mestizaje: el espíritu moderno occidental se retrae hacia lo nacional y tradicional, acercándose empáticamente hacia el espíritu del “indio antiguo”, descendiendo en la jerarquía civilizatoria para luego volver a ascender, arrastrando al indígena hacia la cultura moderna.

Las prácticas y las producciones artísticas ocupan un lugar privilegiado en el corpus del folclore recortado por García. Haciendo sistema con las consideraciones sobre la mentalidad popular indiana que abordamos anteriormente, García vuelve a remarcar la función cumplida por el arte, en la religión católica colonial, como clave de la exitosa interpelación emotiva de lo popular indiano, destacando el rol que cumplían la música y la plástica en el ejercicio de la "docencia católica". Para apuntalar este argumento, cita un párrafo de Siete ensayos de interpretación de la realidad peruana, precisamente uno de los (pocos) pasajes en que Mariátegui vuelve a reactualizar una jerarquización etnocéntrica de las culturas: "el catolicismo por su liturgia suntuosa, por su culto patético, estaba dotado de una 
aptitud tal vez única para cautivar una población que no podía elevarse súbitamente a una religiosidad espiritual y abstractista" (Mariátegui, citado en García [1930] 1937: 113).

En consecuencia, Valcárcel propone la gestación de un "nacionalismo artístico" con el que -podemos inferir- pretende disputar el sustrato religioso de lo popular mestizo, que considera en manos de los políticos tradicionales desde la república:

La indianidad perdura como ansia o voluntad creadora. Y ese sentimiento se nutre de los Andes, emocionalmente, y del universo, idealmente. Nuestro nacionalismo artístico será acentuar la emoción y la idea en armonía y originalidad./ La sierra surperuana ha sido la creadora del arte más original de América y para ella el arte es su inquietud más fecunda. El arte es el lenguaje del serrano neoindio. Su grandeza de todos los tiempos está en él (García [1930] 1937: 139).

Si para García "el arte es el lenguaje del serrano neoindio", éste se impone entonces como el mejor medio para interpelar a los sectores populares mestizos, y direccionarlos hacia las metas que propone El nuevo indio, y más precisamente hacia las artes plásticas (García [1930] 1937: 139):

El arte social más educativo del coloniaje fué la plástica, especialmente la pintura y la escultura. Entre la pintura, las escenas costumbristas, lo mismo que en la escultura [...]. El arte nuevo propiamente neoindio de nuestros días, será aquel que aborde los problemas sociales más inmediatos (García [1930] 1937: 138).

Los intelectuales regionalistas deben valerse entonces de las prácticas y de los objetos folclóricos como insumos para generar un "arte nuevo" eminentemente iconográfico; ${ }^{49}$ al incorporar esos materiales populares en sus producciones, el "arte nuevo" logrará asociar el ideal regionalista con los significantes tradicionales de la cultura indiana (como el paisaje y la naturaleza andina, objetos tradicionales de adoración a través del sol, la tierra o los Andes). En ese sentido, García afirma que "el indio moderno, el nuevo indio, busca la solución para dar al Apu otro sentido" (García [1930] 1937: 16). Como se observa en el párrafo siguiente, el ensayista describe -y prescribe- esa tarea de resemantización regionalista, en la que el arte debe capitalizar - desde el punto de vista cultural- la adoración del paisaje, supuestamente inherente a la religiosidad serrana:

\footnotetext{
49 "Un arte verdaderamente americano tiene que inspirarse en el folklore integral” (García [1930] 1937: 148).
} 
El culto a los Apus, al sol resplandeciente de estas abruptas serranías andinas lo hemos trocado en fervientes sentimientos de solidaridad regional, en culto a las ruinas, en arqueología, en ideales nacionalistas, en ansias de una cultura americana, en un arte pictórico que hace la celebridad de todos los artistas, no precisamente indios, sino americanos, que captan la belleza de este lado del Perú y de este rincón de América./ Apu moderno es el paisaje inundado de sol; es la inquietud de las juventudes serranas a tomar un papel directivo en la evolución nacional y el anhelo de su regeneración histórica. El Apu es la tierra americana original de inmensa fuerza plasmadora; es la defensa de la personalidad y de su energía viril de creador. Este Apu ya no puede ser cerrazón localista sino amplitud expansiva americana y universal; culto a los Andes como medio de una superación sobre uno mismo; no puede ser embeleso tradicionalista, sino tránsito hacia el mundo y hacia el futuro (García [1930] 1937: 20).

La emoción religiosa del paisaje queda así unida -por contigüidad- a la ideología regionalista: solidaridad regional, nacionalismo regionalista, reivindicación de la historia local como antecedente que legitima la voluntad serrana de dirigir los destinos nacionales para lograr "la unificación espiritual del Perú". Pero además, en ese párrafo, el rol del intelectual se vincula con las "juventudes serranas", presentadas como el sujeto en torno al cual conformar una dirigencia nacional alternativa.

\section{Intelectuales indigenistas/ intelectuales regionalistas}

Esa mención de las "juventudes serranas", en el párrafo arriba citado, da cuenta de la concepción de los intelectuales que se despliega en El nuevo indio. El ensayo prescribe quiénes deben ser los sujetos dirigentes que encabecen el programa culturalista propuesto. García deja entrever allí una definición normativa del intelectual y de su tarea, plasmada en su representación del "indigenista", etiqueta bajo la que se presenta, en realidad, un modelo de intelectual regionalista, dado el fuerte sesgo anti-indígena que hemos advertido en el ensayo. Esa figura se construye por oposición a la del intelectual "tradicionalista", que se vincula con posiciones “incanistas” y con la política oligárquica. El texto critica a este último modelo -y con él, a las clases dirigentes, tal como dijimos-, como el verdadero origen de los males nacionales:

El regionalismo serrano más que una reacción de "políticos" resentidos y en desgracia es y tiene que ser siempre un estado de alma beligerante, cargado de nobles idealidades para alcanzar la nacionalidad, para llegar a ese espíritu americano neoindio, puesto que la sierra fue la entraña de la cultura. El "regionalismo" fue en todos los tiempos, aún desde los incas, 
voluntad indiana de creación nacional, antes que un "bando" de política criolla o un círculo provincialista (García [1930] 1937: 110-111; cursivas en el original).

Elitismo, idealismo y juvenilismo son coordenadas fundamentales en la construcción de la imagen del intelectual indigenista/regionalista. Sumadas a la insistencia en la figura modélica del artista, estas coordenadas nos permiten ubicar al autor en continuidad con la tradición arielista del modernismo latinoamericano:

[El destino de la sierra es] ser siempre la entraña de la nacionalidad y el incentivo para la creación valiosa, la fuente donde abreve la América sus ansias de cultura. Su energía siempre juvenil, bárbara acometida contra lo que tiende a perennizarse. Y este rol no es precisamente el que incumbe sólo a la masa, sino también a ciertas minorías que surgen del pueblo y de esa misma multitud. Toda acción de valor social es obra de quienes se hallan impelidos por sentimientos elevados y por deseos beligerantes. La masa tiene la función de sostener lo más fecundo del pasado, pero en núcleo tiene la obligación moral de abrir otras vías para el curso de esa represa de la historia./ De las juventudes serranas, pero de esas juventudes nobles, generosas e idealistas, nacerá la otra cultura del mañana. De la "revolución", no de la mecánica que repite. Ese espíritu joven que se rebela contra lo que ha envejecido el uso o ha mellado el tiempo, ese es el hombre que necesita América (García [1930] 1937: 192).

En este párrafo, los intelectuales se recortan como una minoría juvenil, "noble" e "idealista"; como un "núcleo" encargado de formar una cultura nueva que pueda orientar a las "masas" por un nuevo camino. Esa tarea se presenta como una "revolución" contra el tradicionalismo. Pero además, hay un señalamiento sobre el origen social de esa minoría que lidera el cambio cultural: ésta procede del pueblo mestizo y de la multitud. En otras áreas del ensayo, la cuestión del origen social del intelectual se vuelve un requisito normativo:

Todo apostolado o afán indigenista tiene que ser vida acrecentada que se nutra del pueblo, de sus raíces afectivas, y que sea la prolongación de su propia alma. Nunca podrá haber ningún guía de la cultura que esté fuera de o contra el pueblo. Mejor dicho, ningún indigenismo auténtico podrá surgir de las posiciones de la burguesía o de la vida burguese [sic], que por esencia es antipopular (García [1930] 1937: 75).

La inflexión antiburguesa no es un elemento extraño a la tradición iniciada por el Ariel de Rodó. Sin embargo, si en el Ariel y en el Modernismo en general podemos encontrar una modulación aristocratizante del discurso anti-burgués, como señala Terán (2008: 160), en el ensayo de García llama la atención el rechazo de toda afinidad posible con ese tipo de sensibilidad..$^{50}$ 
Ahora bien, más allá de esta modulación populista sobre el origen social de los intelectuales, no hay en el ensayo ningún tipo de apuesta en favor de que los sectores populares se organicen políticamente, y menos aún de que actúen autónomamente, lo que va en contra de la propuesta de romper con la dominación tradicional de los caudillos oligárquicos. En ese sentido, el elitismo sigue operando plenamente en El nuevo indio, y los subalternos quedan reducidos a ser "la fragua donde se puede forjar la gran pasión que trascienda los linderos provincianos" (García [1930] 1937: 164). Bajo la acción de los ideales -afirma García-, el “espíritu elemental” de lo subalterno perderá su “fuerza corrosiva y será ennoblecido por esa minoría de almas selectas contra quienes se da de bruces el rudo monstruo" (García [1930] 1937: 164). La tarea del intelectual, representada bajo la figura de artesano o el artista que moldea en la fragua lo popular mestizo, se extrema cuando se prescribe su acción sobre los sujetos indígenas:

Se piensa con un criterio un tanto localista que la cultura nacional y aún americana está reservada exclusivamente al indio y se plantean fórmulas para solucionar el tan manoseado "problema del indio", "la redención del indio" y todo ese romántico tradicionalismo de ciertos grupos llevados por el afán de volver a lo americano -afán encomiable, por supuesto-; se equivocan proclamando el retorno al incanato. ¿Qué significa el anhelo de redimir al indio de su situación actual? En buena cuenta, elevarlo a la altura de la conciencia americana del presente; vigorizar la simplicidad de su alma acrecentándola con todo aquello que aun cuando sea extraído de la tradición y de la tierra esté acorde con la riqueza espiritual de la humanidad de hoy. Redimir al indio será engendrar en su alma una nueva conciencia americana, hacer fecunda su tradición en aquello que es fecunda toda tradición, pero no pretender realizar vida histórica valiosa manteniéndole dentro de esa misma tradición. Redimirle será incrustarle sentimientos e ideas distintos y hasta opuestos a los suyos (García [1930] 1937: 109; cursivas nuestras).

La referencia a la fragua -el taller del artista- y la figuración de la práctica intelectual como la acción de "incrustar", sugieren una representación del intelectual como un trabajador manual -quizás un orfebre o un herrero- que combina la figura del crisol (presente en el discurso mestizófilo de Rojas) y la del artista o artesano que se vale de la fuerza para dar forma a la materia (que en el Ariel se presentaba bajo la metáfora del escultor), al tiempo que permite reforzar la identificación "desde arriba" del intelectual con el subalterno, a través de la metamorfosis del letrado en obrero. Acorde con esas representaciones, la tarea del intelectual es fundir a los diferentes "espíritus" en una cultura nacional mestiza y, a la vez,

\footnotetext{
${ }^{50}$ De hecho, aún en el Modernismo la oposición al burgués es un tópico con modulaciones ideológicas diversas (que van del aristocratismo al proto-populismo). Piénsese, por ejemplo, en las ambivalencias del ataque al burgués por parte de José Ingenieros y de Leopoldo Lugones en el periódico La Montaña.
} 
apelando al mismo tipo de figuración patriarcalista con que se pergeña la educación de las masas en el Ariel, "incrustar" el ideal occidental sobre los sujetos indígenas, aunque ello vaya en contra de sus tradiciones culturales.

Finalmente, en algunos pasajes, emerge una concepción del intelectual afín a la ponderación de los "grandes hombres" como un factor efectivo para la interpelación y movilización del "pueblo mestizo", que en principio contradice las áreas del ensayo en que García critica y propone combatir la política tradicional de caudillos afines al orden oligárquico. Esto puede observarse, por ejemplo, en la propuesta de convertir a Túpac Amaru en un modelo heroico para los intelectuales regionalistas:

Si el alzamiento de Manco II, dos siglos antes, fue el intento de la supervivencia del "inkario", es decir, del pasado, el de Condorcanqui es el planteamiento de los problemas del porvenir. Manco II fue el caudillo incaico; Túpak Amaru el caudillo indiano. El cacique de Tungasuca fue, por su ideología, por su espíritu y acaso también por la sangre, todo un mestizo, valga decir, un hombre renovado y sacudido de su tradicionalismo incaico (García [1930] 1937: 151).

\section{Y luego:}

Su rebelión es la protesta de la sierra por el centralismo del gobierno español, localizado no sólo en la capital del virreinato, sino en Madrid, y la defensa de su autonomía cuando pide la supresión de los corregimientos por las alcaldías vecinales y el establecimiento de una audiencia y de un virreinato en el Cuzco (García [1930] 1937: 153; cursivas en el original).

Túpac Amaru es representado como un caudillo mestizo, regionalista y anticentralista; líder cuya acción orientada a "cortar el mal gobierno" pone en marcha y articula el "movimiento indianista". Inclusive, en lo que parece una velada amenaza -que repone la ya mencionada oscilación entre el líder positivo y el líder peligroso-, García señala la fugaz radicalización de Condorcanqui frente a la dominación centralista, que lo "torna en el Tamerlán de las reivindicaciones regionales [...], todo un bolchevique cuando ahorca corregidores, se apodera de los caudales públicos [...], incendia y saquea las grandes fábricas y obrajes de la época, donde el indio extinguía su vida trabajando para los amos" (García [1930] 1937: 152-153; cursivas en el original).

En torno a este modelo de individuo "representativo de la humanidad americana que nació desde la conquista" (García [1930] 1937: 155), el ensayo deja abierta la posibilidad de que surja un liderazgo carismático entre los intelectuales regionalistas. 
A partir de este análisis, podemos ubicar El nuevo indio en un lugar atípico dentro de los indigenismos peruanos, principalmente por su apelación al mestizaje y al mestizo, que desplaza al indígena y su tradición cultural como ejes de la reconfiguración de la nación.

El planteamiento del problema nacional y el abordaje del "otro", apelando al concepto de cultura desde un encuadre espiritualista, evidencian una voluntad de ruptura con el racismo científico. Sin embargo, como vimos, el pasaje al culturalismo sostiene, ahora en el plano de la cultura, las mismas operaciones ideológicas de inferiorización y exclusión del indígena llevadas a cabo previamente por el racialismo, configurando lo que Wade (2000: 29) define como "racismo cultural". Esto se ve reforzado por la mirada tradicional del mestizaje presentado como una arena en la que se desarrolla un enfrentamiento violento entre culturas y donde - desde una posición eurocéntrica- se considera deseable que el polo occidental se imponga sobre el indígena (tarea que debe ser encarada por los intelectuales indigenistas/regionalistas). Lo indígena queda relegado a una mera pincelada decorativa, cuando no es eliminado. ${ }^{51}$ De ese modo, afirmar la necesidad de fortalecer el proceso de mestizaje -apelando a la expansión de una cultura nacional mestiza de base folcloricaimplica prescribir una suerte de eugenesia culturalista que hace reemerger, más allá del vocabulario propio del espiritualismo, la perspectiva del racialismo positivista. ${ }^{52}$

Además, si bien el enfoque culturalista le permite a García preguntarse por la especificidad del aporte de la cultura indígena al mestizaje y a la cultura nacional (contrariando la mirada racialista de entresiglos, que inferiorizaba al indígena, negándole todo trazo de cultura y relegándolo al ámbito del mero instinto, al orden de la naturaleza), también le permite no dar cuenta de la desigualdad, de las asimetrías sociales existentes entre

\footnotetext{
${ }^{51}$ Autores como Gruzinski (2000) consideran necesario, por el contrario, pensar cuestiones de fronteras y mixturas en torno al mestizaje. Su enfoque propone mirar atentamente los "espacios de mediación" sin reducirlos a la síntesis y la homogeneización, permitiendo pensar el mestizaje como una dinámica inestable, móvil, cambiante, irregular, imprevisible y fluctuante.

${ }^{52}$ Ello coincide con la definición del mestizaje como proyecto de las élites de América Latina que provee De la Cadena (2007: 31): "El mestizaje [...] es un proyecto histórico de construcción de nación moderna [que] a cambio de hacer vivir la mezcla racial-cultural, que (inevitablemente) lo antecede, promete la purificación ontológica-epistémica de su población, dejando morir aquello que estorba esta homogeneidad".
} 
los subalternos indígenas y los sectores dominantes. En ese sentido, la postulación del predominio de la cultura indígena en el campo artístico colonial, oculta $-\mathrm{o}$ al menos dulcifica- su dominación opresiva.

Esta ocultación de la conflictividad (económica, social y política), implícita en la reivindicación cultural de García, descansa en una concepción de la cultura entendida como una esfera autónoma. En esta dirección, la crítica que formulamos a El nuevo indio puede ser profundizada a partir de varios autores contemporáneos que abogan por la "reforma" del concepto de "cultura", mediante la reintroducción de la dimensión y las problemáticas del poder implícitas en dicha perspectiva (Williams, 1980; García Canclini, 1994; Ortner, 1999; Grimson y Semán, 2005; De la Cadena, 2007; y Grimson, 2011, entre otros). En especial, algunos autores como Gruzinski (2000) y Abu-Lughod (1991) han señalado, como un límite del concepto de "cultura", el hecho de que privilegia el abordaje de la diferencia que, por añadidura, siempre conlleva jerarquizaciones entre quien enuncia ("nosotros") y los otros.

Todo ello conduce a García hacia una posición en extremo devaluadora de la alteridad indígena, a la que no llega ningún otro exponente del indigenismo peruano. Al representar a los indígenas como sujetos incapaces de "evolucionar" espiritualmente -desde una perspectiva que considera a Europa como punto cúlmine del progreso civilizatorio universalles atribuye la causa de su propia subalternidad, dejando de lado, nuevamente, toda variable del orden de la dominación social tanto histórica como contemporánea. En consecuencia, el indígena vuelve a ser representado como el obstáculo para el progreso de la región y de la nación.

Finalmente, si bien lo popular mestizo es valorizado en el ensayo por sus aptitudes estéticas y su conexión telúrica con la nacionalidad, la tarea del intelectual se diseña desde parámetros elitistas, paternalistas y autoritarios que retoman postulados normativos, presentes en la tradición arielista, sobre la relación asimétrica entre intelectuales y sectores populares. De ese modo el intelectual indigenista/regionalista -representado normativamente sobre la figura del artista- debe "incrustar" ideales, a los sujetos en proceso de mestizaje, con el objetivo de conducirlos hacia metas de "civilización" y "progreso" que reponen, bajo una pátina culturalista, la mirada evolucionista, euro y etnocéntrica del positivismo de entresiglos. En ese sentido, la diferencia más sensible es la prescripción normativa sobre el origen social - popular y mestizo- de los intelectuales. Como intentaremos argumentar a continuación, se 
puede relacionar esa perspectiva con la crisis de la matriz oligárquica en la región de Cusco y de Perú en general. 
Disputas y debates al interior de la élite de Cusco: confrontando "por fuera de la política"

¿Cómo explicar las diferencias entre las modulaciones incaístas y mestizófilas del indigenismo regionalista de Cusco en los años veinte, analizadas en las fuentes? ¿Se puede pensar que, en esta etapa, el regionalismo cusqueño está siendo atravesado también por la crisis de las instituciones oligárquicas, y que, en consecuencia, en los discursos se recorta una puja entre los indigenistas por clausurar de un lado (y acceder del otro) a instituciones sociales y de gobierno tales como la universidad o el estado en general, incluso disputando la legitimación de un modelo o rol de intelectual? ¿Se puede entrever en las fuentes la erosión de las prácticas políticas de la oligarquía, e incluso los conflictos sociales generados por el crecimiento de las clases medias - como señalan Deustua y Rénique- que pujan por ingresar a las instituciones del estado, y también por tomar roles dirigentes en la sociedad y la política? ¿No es ese el límite que ponen en evidencia muchos reformistas universitarios, al cuestionar la idea de que las transformaciones de las universidades puedan extenderse a toda la sociedad? Y por fin, ¿no es ésta la típica contradicción de las alas reformistas de las oligarquías latinoamericanas en los primeros años del siglo XX? Para indagar en torno a estos interrogantes, detengámonos en considerar el vínculo conflictivo que establece García con Luis E. Valcárcel.

El discurso mestizófilo que presenta El nuevo indio resulta, en términos generales, revulsivo para la élite de Cusco y en particular para ciertos modelos de intelectual que circulan en su interior, como el del indigenista incaísta que se recorta en Tempestad en los Andes. Si bien no puede soslayarse el hecho de que García forma parte de esa élite, ni tampoco la existencia de sensibles puntos de continuidad con ésta en su visión sobre los intelectuales y sus prácticas -como el énfasis regionalista y anticentralista, o la concepción elitista, autoritaria y paternalista de la tarea intelectual-, la centralidad otorgada a lo mestizo y la prescripción normativa sobre la necesidad de que los intelectuales sean ellos mismos mestizos -espirituales- y de origen popular, son elementos que cuestionan los parámetros identitarios de la élite cusqueña, y que buscan erosionar los criterios de legitimidad establecidos para monopolizar el ejercicio de la actividad letrada y el control de los recursos institucionales del campo intelectual. 
Como señala Avanza, la élite cusqueña había construido un discurso de autoctonía en base a una visión romántica y ahistórica de los incas, con el objetivo de dotarse de una identidad gloriosa y completamente americana, para oponerse a las clases dirigentes de Lima. En esa contraposición, como ya hemos visto, la identidad cusqueña pretendía lograr una legitimidad política de amplitud nacional (Avanza, 2005: 138-140).

Ahora bien, ¿cómo funciona esa identificación hacia el interior de la sociedad regional? Como hemos argumentado, lo incaico forma parte de los gustos e intereses de la alta sociedad cusqueña. En consonancia con la estética modernista y su interés por la Antigüedad clásica, la élite cusqueña establece en torno a lo inca una suerte de clasicismo localista que se traduce en el gusto por la historia, los monumentos, los mitos incas y la lengua quechua. Al apelar a esos elementos de la alta cultura, la identidad cusqueña refuerza, hacia el interior del campo cultural de la región, un criterio de distinción que establece pautas de legitimación social y mecanismos de exclusión (algunos miembros de ese grupo se vanaglorian incluso de tener un inca noble en su genealogía). La identificación incaica excluye manifiestamente lo popular mestizo y su cultura y, consecuentemente a los sujetos designados como mestizos. El estatuto de mestizo, como vimos por ejemplo en Tempestad en los Andes, se considera infamante, impuro y, por ello, no se lo admite como legítimamente perteneciente a la élite social y/o intelectual (Avanza, 2005: 144-155).

La recuperación de lo mestizo y la prescripción normativa sobre el origen de los intelectuales que se esboza en El nuevo indio parecen estar desafiando la configuración excluyente de la élite local y su definición normativa sobre los intelectuales. Ese desafío puede relacionarse con el proceso de expansión de las capas medias y la actividad intelectual que mencionamos al comienzo de esta tesis, y que presupone una presión sobre las instituciones vinculadas al Estado oligárquico que, en los años veinte, atraviesa momentos de crisis, transformación y recomposición (Deustua y Rénique, 1984).

De hecho, algunos sucesos ocurridos en Cusco durante el último trienio de los años veinte dan cuenta de la presencia de conflictos en el interior de la élite intelectual, que pueden vincularse con esa puesta en crisis de los patrones de sociabilidad de raíz oligárquica, en base al crecimiento de las clases medias, que tienen como hito los movimientos de reforma universitaria iniciados una década antes en todo el continente.

En ese sentido, resulta interesante analizar, como ejemplo de ese conflicto, el serio enfrentamiento por la dirección de la Universidad de Cusco ocurrido en mayo de 1927, y que 
involucra precisamente a García y a Valcárcel. Como veremos, estos hechos -0 , mejor, el proceso social que los contiene- contribuyen a apoyar algunas claves del análisis que hemos realizado de El nuevo indio, aunque nuestra intención no es reducir las claves explicativas al itinerario o a la sociabilidad intelectual de su autor. ${ }^{53}$

En 1927 Eufrasio Álvarez, el sucesor del norteamericano Albert Giesecke -que años antes había sido nombrado Director General de Educación por Leguía-, deja libre el Rectorado de la Universidad; García se postula como candidato a rector, propuesto por el claustro de alumnos y la Asociación Universitaria -quienes lo proclamarán luego "Maestro de la juventud"- y apoyado por una mínima parte del profesorado. ${ }^{54}$ En la asamblea docente, Valcárcel, junto con el resto de los catedráticos, le bloquean a García el acceso al cargo de Rector, reeligiendo a Álvarez, quien ya tenía decidido de todos modos dejar el rectorado, por lo que renuncia. ${ }^{55}$ Los estudiantes declaran entonces una huelga, ante la cual el rectorado, bajo el control de la fracción que rechaza la candidatura de García, responde cerrando la Universidad.

Antes del conflicto, los artículos del diario El Comercio presentan a García como un candidato de carácter modernizador y de arraigo popular -dado su apoyo por parte del claustro estudiantil-, vinculándolo con un perfil de profesional ligado a la enseñanza, distanciado de toda actividad política $\mathrm{y}$, sobre todo, de la imagen del político tradicional (asociado, en los discursos de la época, con la búsqueda de rédito personal y con la corrupción):

Para García el rectorado de la Universidad será cargo exacto a su vocación docente, donde, aparte de prestigiarse personalmente, prestigie el magisterio de la enseñanza apartándolo de toda concomitancia e influencia extrañas; no verá en él una plataforma social, política o de otro orden, porque vive alejado de esas actividades para dedicarse exclusivamente a su vida de maestro, así es que de su labor han de desprenderse beneficios positivos i han de ser corregidas muchas corruptelas i prácticas viciosas que parecen cobrar arraigo en nuestro centro facultativo./ Paso a la juventud ("Renovación Universitaria" en El Comercio, Cusco, 17 de mayo de 1927).

\footnotetext{
${ }^{53}$ Ese sería en cambio el caso de Skinner (2000) al confiar en la intención del autor como clave explicativa de las fuentes.

${ }^{54}$ Quienes apoyan a García son los profesores David Chaparro, Leandro Pareja y Federico Ponce (El Comercio, Cusco, 14 de julio de 1927).

${ }^{55}$ No votan a García: Luis E. Valcárcel, Cosme Pacheco, José Gabriel Cosio, Rafael Aguilar, Fortunato L. Herrera, Gayino Bueno, Antonio Lorena, Víctor Rivero, Víctor Guevara, Manuel Jesús Gamarra, Oscar Saldívar, Félix Cosío, Luis Felipe Paredes, Angel Ugarte, Víctor Guillen, Francisco Sivirichi. Dato inferido de la Revista Universitaria. Órgano de la Universidad del Cuzco, primer trimestre de 1926.
} 
Una vez reelecto Álvarez, y proclamada la huelga estudiantil, los artículos de El Comercio -en su mayoría no firmados- deslizan una interpretación del conflicto precisamente como una puja entre sectores políticos tradicionales -que conspiran "en el Club, entre una bier y un pisco"- y sectores reformistas, conformados por la juventud encolumnada detrás de García ${ }^{56}$, en una alianza que pretende lograr

...una universidad que deje de ser un centro expedidor de títulos doctorales para convertirse en una institución de cultura, $i$ entienden como cultura universitaria la orientación espiritual hacia la filosofía, hacia el arte, hacia la acción fecunda. Menos doctores i más hombres, exclaman los universitarios cusqueños ("Menos doctores y más hombres, reclaman, como declaración de principios, los universitarios cuzqueños" en El Comercio, Cusco, 14 de julio de 1927).

Nótese que el programa reformista coincide con las coordenadas ideológicas de El nuevo indio, al presentar un énfasis idealista, contrario a la política y al perfil de intelectual tradicional encarnado por la figura del doctor.

Ahora bien; algunos datos que pondremos en consideración no nos permiten vincular estos hechos con un ataque radical a las prácticas oligárquicas, como las que por entonces está llevando adelante parte del movimiento anti-oligárquico en todo el país, con epicentro en Lima; aunque indudablemente buscan erosionar los límites de la élite social, parecen, sin embargo, no trascender el mero enfrentamiento interno entre fracciones modernizadoras y tradicionales que disputan espacios de poder en el interior de la élite, pero sin romper de lleno con la visión oligárquica del mundo. ${ }^{57}$

Esta sospecha se ve avalada por el hecho de que el diario El Comercio, dirigido por José Ángel Escalante, que patrocina y defiende la posición de García, es un órgano afín al gobierno de Leguía desde principios de los años veinte. Y si bien esto no implica necesariamente el encuadre de la totalidad de los colaboradores del diario como afines a Leguía, ni tampoco tenemos datos para atribuirle esa posición a García, el hecho de que el

\footnotetext{
${ }^{56}$ Otro artículo vuelve a enfatizar a García como adversario de las prácticas políticas tradicionales: "García, joven con espíritu valiente i rectilíneo, jamás ha militado en nuestra política criolla" ("Por las aulas universitarias" en El Comercio, Cusco, 16 de junio de 1927).

${ }^{57}$ Así lo sugiere también una interpretación del conflicto enunciada en uno de los artículos citados de $E l$ Comercio como una disputa entre "civilistas" y "pierolistas", oposición que demarca una inflexión antipopular y populista, respectivamente, en los grupos oligárquicos que participan de la "República aristocrática". Veamos: "Los señores catedráticos han unificado su opinión en repetidos conciliábulos, han firmado un compromiso para no aceptarlo de ningún modo a García, primero, o de renunciar a sus cátedras si por algún acaso llegase al rectorado. Se han destapado en sus encubiertos odios. Civilistas como son, han repetido la frase histórica: antes los chilenos que Piérola... [...] ¿La imposición chilena pretende que aceptemos a García Calderón?; no, señor: Uriel García (Piérola) o nadie. Tal es la opinión del país, digo de la juventud" ("Sobre la huelga universitaria" en El Comercio de Cusco, 6 de junio de 1927).
} 
propio Escalante intervenga en el conflicto en favor de los huelguistas, y en calidad de diputado leguiísta por Acomayo, nos permite pensar en la posibilidad de un intento de avance, de los sectores de la élite afines al gobierno, contra los sectores tradicionales, orientado a desalojarlos de los espacios institucionales (pues, como ya hemos señalado, esta es una de las prácticas políticas emprendidas por Leguía para propiciar una modernización que, no obstante, continúa la modalidad oligárquica de gestión del Estado)..$^{58}$

Más aún, es el propio Escalante quien acude al presidente Leguía y a su ministro de educación, Olivera, para solicitarles que intervengan en el conflicto. En respuesta, el gobierno designa una comisión reorganizadora para que elabore un plan de reformas, en la que participan profesores de ambos grupos en pugna, en partes iguales (Fortunato L. Herrera, Luis Valcárcel, José Gabriel Cosío, Uriel García, Leandro Pareja, Alberto Araníbar y José Segundo García Rodríguez), favoreciendo claramente al sector afín a García que mejora su posición respecto de la que tenía en el Consejo de Profesores, donde contaba sólo con tres votos de un total de diecinueve.

Otro indicio de este carácter "interno a la élite" es la desvinculación de García de todo referente político del campo de la oposición al Oncenio de Leguía -que, a fines de los veinte, cuenta con un vasto desarrollo, que incluye redes locales y continentales-, permaneciendo en una posición apolítica respecto de la concepción tradicional de ésta, pero también respecto de las nuevas fuerzas políticas emergentes. Así se observa en un artículo del propio García:

Estoi completamente de acuerdo con Velazco Aragón en calificar ese conflicto como una pugna de dos espíritus; uno tradicionalista apegado a las antiguas formas, respetuoso de las costumbres, adherido a los prejuicios del convencionalismo social i político, antidemocrático, i otro, juvenil, innovador, rebelde al uso i a la costumbre, apolítico, en el sentido de la vieja política. Fue el choque de un frente que conservaba los rezagos del pasado i otro completamente sacudido de su tradicionalismo y consciente de sus destinos futuros./ La reforma de la universidad del Cuzco no será obra de los "Catedráticos"; se deberá exclusivamente a la acción desinteresada de una juventud de alta idealidad que anhela inyectar en las aulas de "San Antonio" un espíritu completamente nuevo ("Apostillas en torno a la reforma universitaria" en El Comercio, Cusco, 10 de octubre de 1927).

Esta enunciación del conflicto, por parte de García, es la de mayor radicalidad de toda su producción en los últimos años de la década del veinte. A partir de enero de 1928, García comienza a publicar versiones preliminares de los apartados de El nuevo indio en las que

\footnotetext{
${ }^{58}$ En ese sentido, cabe volver a remarcar el inicial apoyo de Leguía al movimiento reformista universitario en Perú, lo que suscita una breve alianza con estos sectores, que cesa definitivamente en 1923, cuando pasa a perseguir y reprimir al movimiento reformista.
} 
pueden observarse algunos ataques a Valcárcel que, por contigüidad en la serie de artículos publicados, queda representado como el referente de las posiciones conservadoras que se denuncian:

\begin{abstract}
Hay una mala comprensión sobre el concepto de nuevo indio [...]. Ni el "indio a caballo", ni el "indio elector", ni el "indio evangelista" pueden simbolizar a esa nueva entidad psicológica nacida desde la conquista de América y que viene a sustituir al hombre del incanato, como cree el autor de "Tempestad en los Andes" en su capítulo "Los nuevos indios", abordando esa perspectiva con recursos más literarios que con pensamientos de verdadera orientación idealista y, por ende, siento decirlo, con cierto menosprecio hacia los escritores serranos que no buscan genuflexos la consagración de la sapiencia limeña -a la que, por otra parte, se la ataca- ni sitio en el cartabón del intelectualismo oficial [...]. Los nuevos indios son los grandes hombres americanos que trazan rumbos ascendentes a la cultura americana, que no predican la mística vuelta a formas del pasado que han concluido con su destino./ No habrá "tempestad en los Andes" con "inkarios" (García, "El nuevo indio" en El Comercio, Cusco, 12 enero de 1928)..$^{59}$
\end{abstract}

Sin embargo, al editarse el ensayo en 1930, las referencias explícitas a la conflictividad que atraviesa a la élite son soslayadas, en sintonía con una toma de posición apolítica o antipolítica, donde la demanda social por el relajamiento de los mecanismos excluyentes (propios de la matriz oligárquica) se articulan sólo a través de las mediaciones operadas por un discurso predominantemente filosófico, tal como el que analizamos en la primera parte de este capítulo.

Finalmente, cabe señalar que el cruce del análisis del discurso y de la sociabilidad intelectual aquí realizados nos permiten leer El nuevo indio como una respuesta a Tempestad en los Andes, que persigue, al mismo tiempo, la deslegitimación de su autor.

\footnotetext{
${ }^{59}$ Otros artículos de El Comercio que van en un mismo sentido son "Neoindianismo", 10 de mayo de 1928, e "Incanidad, indianidad", 29 de mayo de 1928.
} 


\section{EI discurso indigenista en el Estado:}

\section{Castro Pozo y Nuestra comunidad indígena}

Desde principios de la década de 1920, la ciudad de Lima vive un proceso de nacionalización indigenista, impulsado por el Estado, que incluye la adopción del 1lamado "neoperuano" en la arquitectura y el urbanismo, un estilo que puede vincularse en esos años a algunas obras del arquitecto y escultor español Manuel Piqueras quien, desde 1919, vive en Lima, contratado como profesor, arquitecto y urbanista por el gobierno (Ramón: 2014).$^{60}$ El diseño del Museo de Arqueología y de la obra urbanística de emplazamiento del monumento a Manco Cápac, en la mayor área recreativa de Lima, el Parque del Retiro, son algunos indicios de la presencia del indigenismo, que se vuelve hegemónico no sólo en el ensayo y la literatura. El Palacio de Gobierno tiene, en los años veinte, su salón de recepción y su comedor decorados bajo esa estética, que amplía la visibilidad a lo precolonial, mediada por motivos tomados de la arqueología nacional, pero haciendo foco en lo incaico. Como afirma Ramón (2014), la apelación a la simbología precolonial, visibilizada y versatilizada por la arqueología de entresiglos hasta los años diez, intenta darle un cariz nacional a la modernización encarada por la "Patria nueva", integrando ese pasado en el imaginario nacional; las figuras incas permiten singularizar personajes heroicos sobre los que el propio Leguía construye su figura como dirigente. Esta variedad estética del "indigenismo oficial" -ensayada desde décadas antes, en las exposiciones nacionales e internacionales en las que se intenta dar cuenta de lo oficialmente reconocido como típicamente nacional de cada república- plantea ir del reconocimiento de lo incaico en el pasado, al de los indígenas de los años veinte, como elemento central de la nacionalidad.

\footnotetext{
${ }^{60}$ Manuel Piqueras es un escultor nacido y formado en España, contratado por el gobierno de Leguía para la realización de varios monumentos, obras arquitectónicas y urbanísticas -incluido el pabellón nacional en la Exposición Iberoamericana de Sevilla de 1929-. Entre las obras realizadas en el período 1919 y 1930, se destacan la fachada de la Escuela de Bellas Artes de Lima, el "Salón Inca" de la Casa de Gobierno de Perú, de estilo neoperuano. Urbanísticamente diseña la Plaza San Martín en el centro histórico de Lima y el Parque del Retiro. Con el golpe militar de Sánchez Cerro a Leguía, cesa su participación en las obras institucionales.

El término "neoperuano" se asemeja al "neocolonial" que autores como Uriel García o, como muestra Mailhe (2017), Ricardo Rojas y Ángel Guido consideran representativo de la nacionalidad continental anclada en el mestizaje cultural.
} 
Siguiendo a Ramón (2014) el Oncenio de Leguía puede considerarse un proceso político en dos actos; expresión de lo que Poole (2000) considera "las cambiantes alianzas de clase" que ensaya la Patria Nueva de Leguía. En la campaña electoral de 1919, Leguía se presenta como el candidato de la renovación que terminaría con las peores prácticas de la "República Aristocrática" y la hegemonía política del Partido Civil, expresión de los intereses de las "grandes familias", al tiempo que fomenta alianzas con los sectores juveniles provenientes de la Reforma Universitaria, anunciando medidas de compromiso con los sectores populares modernos y tradicionales, vehiculizados por un discurso indigenista.

Aunque construye un universo discursivo ligado a lo indígena como eje de la nacionalidad, Leguía no altera la base material del régimen oligárquico peruano: intenta modernizar la economía a través del establecimiento de un vínculo estrecho con el capital financiero y empresas estadounidenses, con intercambios onerosos que afectan los bienes públicos nacionales. Pero sí fomenta un orden simbólico que, además de discursos escritos, configura un universo escenográfico donde la arquitectura y el urbanismo, la escultura, la pintura, la música, la literatura, el teatro, la danza, las artes gráficas y los deportes se vinculan a la discursividad estética del neoperuano, entendido como un espacio de disputa por la representación de los indígenas, en el que incaístas de perspectivas diversas se cruzan con promotores de las culturas preincaicas de la zona costera y otras corrientes arqueológicas que viabilizan las pujas interregionales.

Entre 1919 y 1923, Leguía busca anular el civilismo y sus fracciones aliadas, mediante el exilio de sus líderes políticos y la cooptación de sus medios de prensa. Al mismo tiempo, inicia una serie de reformas pro-indígenas: la comunidad indígena es constitucionalmente reconocida en 1920; en 1921 crea la Sección de Asuntos Indígenas; ese mismo año forma el Comité Pro Derecho Indígena Tawantinsuyo y se realizan cuatro Congresos Indígenas en Lima, hasta 1924; crea una comisión presidida por José Antonio Encinas para buscar soluciones legales a las quejas de las comunidades ante los abusos de los hacendados; produce en esos cinco años "más decretos, leyes y resoluciones sobre los indígenas que en todo el siglo anterior”. Es en esta etapa que Leguía se encarga de popularizar su apodo de Wiracocha.$^{61}$

\footnotetext{
${ }^{61} \mathrm{Tal}$ como se comprueba al revisar la correspondencia entre los indigenistas de la época, "Wiracocha" es un término común para los liderazgos intelectuales y políticos entre los intelectuales del mundo andino, en la década del veinte.
} 
Hildebrando Castro Pozo, Jefe de Asuntos Indígenas del Ministerio de Fomento peruano entre 1920 y 1923, pone el foco en la reivindicación del indígena del presente como eje de un proyecto productivo $-\mathrm{y}$ en cierta medida estético- para Perú. ${ }^{62}$ Esta característica resulta interesante para indagar en torno a los matices y las divergencias al interior del “indigenismo estatal”. El texto Nuestra comunidad indígena (1924), de Castro Pozo, busca manifiestamente la atención del estadista, del legislador y del sociólogo (Castro Pozo [1924] 1979: 52-53). Resulta claro que el ensayo tiene como finalidad intervenir en el contexto social peruano de los años veinte. En particular, marcado por el ámbito estatal en que se produce, el texto de Castro Pozo está diseñado para fungir como un insumo para la dirigencia estatal, a fin de producir un conocimiento que permita diseñar mejores políticas públicas de gobierno.

A partir de 1923 esas tensiones del indigenismo oficial se resuelven -en gran medidahacia el predominio de posiciones conservadoras al rearticularse el vínculo del gobierno con las fracciones oligárquicas provinciales, organizadas en la Liga de hacendados, que reaccionan a la comisión liderada por Encinas. Desde ese momento el gobierno limita la acción contra los latifundistas, e incluso reprime las protestas indígenas y paulatinamente va desguazando el entramado legal institucional proindígena. En 1923, visto como un elemento molesto para este nuevo sentido político, Castro Pozo es enviado al exilio. No obstante, mientras las medidas en favor de las comunidades indígenas concluyen, Leguía acentúa su discurso indigenista: en este sentido, es evidente que percibe tempranamente el valor discursivo del indigenismo, donde el indígena puede estar o no en el centro de las políticas estatales, demostrando una gran capacidad para articularse con todo tipo de iniciativas y orientaciones políticas.

\footnotetext{
${ }^{62}$ En efecto, durante los cinco años que demora la preparación de Nuestra comunidad indígena Castro Pozo forma parte del Estado peruano, en el Ministerio de Fomento como Jefe de la Sección de Asuntos Indígenas. Desde esa función promueve la organización de los "Congresos Indígenas Tahuantinsuyo" en los que participan personeros de las distintas comunidades. Estos congresos se realizan entre 1921 y 1923, año en el que Castro Pozo se ve obligado a exiliarse tras oponerse a la reelección de Leguía. Sin embargo, en 1924 regresa a Perú y en 1925 completa sus estudios de abogado. Tras la muerte de José Carlos Mariátegui, la tendencia comunista al interior del Partido Socialista Peruano - fundado por Mariátegui en 1928- cambia su nombre por Partido Comunista Peruano. En 1931 Castro Pozo funda el Partido Socialista del Perú. La similitud en los nombres, no parece señalar una proximidad ideológica con Mariátegui, que en Castro Pozo parece estar vinculada a una matriz decimonónica de socialismo. De hecho, participa como Diputado entre 1931 y 1936, luego del golpe intra-oligárquico, y también autoritario, que derroca a Leguía.
} 
En Nuestra comunidad indígena, Castro Pozo propone una solución al "problema del indio", apoyándose en la valoración positiva del indígena de las comunidades, que rompe con la mirada negativa proyectada por los intelectuales de entresiglos. La clave de lo que podemos llamar su "proyecto de integración de los indígenas" reside en la inclusión de las comunidades en la vida económica nacional. En el texto se producen representaciones imaginarias que resignifican al indígena, considerándolo como un trabajador productivo para la revitalización económica y para la modernización de Perú.

Su estudio del estado actual de las comunidades encuentra aspectos positivos y negativos, fortalezas y obstáculos para el logro de esa meta. Propone que la comunidad indígena sea el modelo de utilización de la propiedad y el trabajo, porque optimiza el rendimiento de la mano de obra indígena (de hecho, presenta algunos "prototipos" de comunidades exitosas que son presentados como modelos), en condiciones opuestas a la explotación tradicional propia del latifundio, denunciado como un "sistema de propiedad territorial que es un verdadero feudalismo" (Castro Pozo [1924] 1979: 52). ${ }^{63}$

No obstante, para Castro Pozo la mayoría de las comunidades presentan serios problemas que dificultan una integración exitosa, por lo que se deben subsanar. Un aspecto es la influencia de instituciones y prácticas tradicionales que bloquean la posibilidad de poner a la comunidad en sintonía con el circuito productivo del capitalismo agro-exportador peruano. El latifundio, la política tradicional, la familia indígena y sobre todo la iglesia y las supersticiones populares de raíz originaria dan como resultado una mentalidad indígena irracional e improductiva, que favorece la perpetuación del abuso, la explotación y el robo de tierras por parte de los hacendados. En este sentido, para el autor, si el indígena se encuentra en una situación de inferioridad, esto depende de causas históricas, sociales y culturales, y por ende, se trata de causas superables.

En efecto, para Castro Pozo los indígenas no están, como sentenciaba la mirada racialista, fatalmente determinados a una perpetua condición de atraso, aunque sí presentan algunos rasgos negativos que deben ser depurados. El obsesivo afán higienista de marcar la

\footnotetext{
${ }^{63}$ Resulta interesante marcar la cercanía que adquiere, cuatro años después, la similar caracterización de la propiedad latifundista, como "semifeudal", en Siete ensayos de interpretación de la realidad peruana de José Carlos Mariátegui.
} 
conducta social del trabajador, y la apelación a la psicología de las multitudes, la psicología social y la psiquiatría para analizar la subjetividad indígena, reactivan el acervo teórico y metodológico del positivismo decimonónico. Cuando Castro Pozo aborda la religión, la superstición y la sociabilidad familiar indígenas, construye representaciones en extremo negativas del indio, en las que vuelven a emerger los elementos y la terminología residuales de la psicología de las multitudes, y algunos lugares comunes de la negativización racialista del positivismo.

El eje puesto en las prácticas productivas y la remoción de las trabas subjetivas a un buen desempeño en el trabajo nos permite reconocer elementos del imaginario modernizador, marcado por el socialismo liberal decimonónico. En ese sentido, el diagnóstico y el proyecto de Castro Pozo tienen una fuerte impronta jurídico-económica a la hora de pensar las prácticas productivas y la organización del trabajo, y a diferencia de otras modulaciones del discurso indigenista, contempla el poder como un elemento central en la dominación del indígena. En el proyecto de desarrollo de Nuestra comunidad indígena, se observa una tolerancia a la economía mixta, en la que se puede leer una apropiación de partes del discurso cooperativista. La cuestión del orden oligárquico de distribución de la tierra queda en un sugerente silencio.

A las complejas coordenadas epistemológicas del ensayo, se agrega un énfasis "romántico" -que convive con las operaciones intrusivas del positivismo en la cosmovisión indígena-, ligado a ese proyecto de búsqueda del éxito industrial para Perú. El autor sugiere condiciones específicas de producción, y propone la industrialización de las artesanías indígenas, mediante la inserción de objetos indígenas contemporáneos (también como acervo para la literatura y el arte burgueses), producidos en "industrias comunales" organizadas formalmente bajo la forma jurídica de la cooperativa. Ese proyecto convive con uno más amplio de fomento de una producción comunal agro-ganadera.

Hay también elementos de la perspectiva culturalista que dinamizan el proyecto de modernización de Nuestra comunidad indígena, al hacer eje en la necesidad de una educación moral al estilo positivista, con énfasis en lo técnico, no exenta de incrustaciones humanistas y enunciados sobre la necesidad de inserción de "ideales" en los indígenas que fomenten el desarrollo y el "progreso" individual y comunitario, para combatir la mentalidad tradicional que merma las capacidades laborales y productivas. Esta área del discurso de Castro Pozo, que promueve la racionalización del trabajo y la producción en las comunidades, para lograr la integración de los indígenas como una fuerza productiva de la nación por vías educativas, 
se conecta con una concepción positiva del mestizaje, que el autor aborda al focalizar las prácticas estéticas.

\section{El ensayo}

Es importante aclarar, en este punto, que de todos los textos que integran el corpus de esta tesis, Nuestra comunidad indígena es el menos abordado por la crítica. Además, las escasas citas y referencias a otras obras hacen más difícil aún su análisis, ya que los discursos que se entrecruzan en su composición permanecen tácitos, pero activos en la representación, gracias al uso de ideologemas, temas y formas de abordar la cuestión indígena (Angenot: 2010), en los que se reconocen las diversas tradiciones intelectuales que se usan en la enunciación.

El ensayo presenta tres interrogantes que el autor busca responder: ¿cómo integrar la comunidad indígena a la sociedad nacional?, ¿qué aportes puede hacer la comunidad al desarrollo nacional?, y ¿qué limitaciones, qué obstáculos presentan las comunidades para su integración, y cómo pueden superarse?

Para responder estas preguntas, Castro Pozo organiza el libro en diez capítulos, en los que desarrolla su mirada sobre el problema indígena, elabora un diagnóstico y plantea posibles soluciones. Aproximadamente la mitad de las casi trescientas cincuenta páginas que lo componen, está dedicada a estudiar las comunidades indígenas existentes. Las clasifica; describe a sus integrantes, y el modo en que producen y se gobiernan; estudia las instituciones y la sociabilidad comunitarias -incluidas las prácticas matrimoniales y familiares- y el lugar de la mujer indígena en la comunidad. Como balance, Castro Pozo expone potencialidades y límites de las comunidades indígenas para ser integradas al circuito productivo del capitalismo agro-exportador peruano, sin modificar los rasgos que, desde una mirada productivista, considera como su mayor fortaleza: el régimen de trabajo comunitario, en el que ve un potencial "contrato múltiple de trabajo". Castro Pozo se vale del conocimiento sociológico, jurídico y económico, con el que analiza los datos de una investigación etnográfica extensa y minuciosa de las comunidades, realizada de primera mano por el propio autor.

La otra mitad del ensayo la destina a describir las prácticas religiosas, los rituales y las fiestas, las supersticiones y la "emotividad estética" de los indígenas. De allí infiere un bosquejo de lo que llama el "alma indígena", en la que encuentra elementos que obstaculizan 
la modernización de las comunidades y su integración a la vida nacional. En esta área del discurso se hace más fuerte la mirada positivista.

El autor, oriundo de Piura - uno de los departamentos costeños más al norte de Perúse presenta bajo la figura del etnógrafo que registra de primera mano, en sus viajes, las prácticas comunitarias indígenas, y las ofrece a un lector que desconoce esa información:

A falta absoluta de fuentes de información, ya que hasta el presente nadie se ha preocupado de estudiar estos fenómenos, he tenido que tropezar con la enorme dificultad de la reserva indígena, la multiplicidad de los dialectos del quechua y la reconstrucción paciente y sistemada [sic] de multitud de leyendas, prácticas o supervivencias que sólo he podido completar teniendo a la vista una serie de datos y observaciones personales (Castro Pozo [1924] 1979: 164). ${ }^{64}$

Las pocas citas de autores de la tradición intelectual local, continental o europea, terminan reforzando la enorme gravitación del etnógrafo como mediador, en contraste con el perfil de los otros ensayos analizados en esta tesis, más apegados a la tradición ensayística observable en los elaborados sistemas de citas y referencias.

En efecto, probablemente por la naturaleza del texto (más afín a un informe burocrático-etnográfico o a un diario de campo, que al vuelo hermenéutico de un ensayo), en Nuestra comunidad indígena el diálogo con las reflexiones previas y contemporáneas sobre la cuestión indígena y la realidad nacional no remite a autores y a fuentes específicas ${ }^{65} \mathrm{La}$ proximidad con respecto a un informe tiene sentido si se considera que el texto es escrito por Castro Pozo mientras dirige la Sección de Asuntos Indígenas de la "Patria Nueva". No obstante, el autor aborda los tópicos propios de la tradición ensayística nacional y

\footnotetext{
${ }^{64} \mathrm{El}$ autor ofrece más datos sobre las condiciones de producción del ensayo remarcando el esfuerzo de su investigación y el valor que tiene ese contacto directo para resolver los problemas nacionales: "[El] presente trabajo, por su mismo carácter de ensayo, comprendo que es imperfecto y adolece de grandes vacíos, como los de una fuente de información más vasta y una estadística pormenorizada de las diferentes productividades industriales indígenas./ La labor que su confección me ha demandado ha sido ardua, pues han resultado escasos los cinco años continuos que me he dedicado a estudiar problema de tanta importancia y trascendencia. En fin, se ha trazado la huella, que me propongo ahondar, y quede la consumación de ésta para inteligencias de mayor capacidad y cultura que la mía, que solamente ha desbrozado en esta selva virgen de nuestra sociología nacional" (Castro Pozo [1924] 1979: 343-344).

${ }^{65}$ Los autores citados son utilizados como apoyatura para la descripción del baile y la música, como por ejemplo Nietzsche (Castro Pozo [1924] 1979:223), Raoul Charbonnel (Castro Pozo [1924] 1979: 237), Dora Mayer (Castro Pozo [1924] 1979: 222), Lafcadio Hearn (Castro Pozo [1924] 1979:157), Abelardo Gamarra (Castro Pozo [1924] 1979: 244), Mariano Melgar (Castro Pozo [1924] 1979: 268), o el libro Arte y Diccionario Quechua Español (Castro Pozo [1924] 1979: 255). Para documentar acciones estatales cita a Saturnino Vara Cadillo (Castro Pozo [1924] 1979: 162), Agronomía Nacional de Lavalle y García (Castro Pozo [1924] 1979: 304-305), el Diccionario Geográfico, Histórico, Estadístico de Germán Leguía y Martínez (Castro Pozo [1924] 1979: 324) y finalmente el diario El tiempo (Castro Pozo [1924] 1979: 244).
} 
continental, tal como son reactivados por los indigenismos de los años veinte, dialogando por ende fuertemente con el corpus de textos que son objeto de nuestra investigación.

\section{Los indígenas en el trabajo comunitario}

Vimos que, para Castro Pozo, el indígena es un sujeto perfectible que, alejado de las instituciones que lo degradan y sumen en la inferioridad, y superadas sus limitaciones psico-físicas, se halla en pie de igualdad con cualquier otro. El autor sale al cruce de los discursos y prejuicios de sentido común que inferiorizan al indígena:

\footnotetext{
Ante nuestro criterio de costeños y mestizos engreídos, todo regnícola es "indio", "tonto" y "despreciable": cualesquiera de aquellos no vale ni un comino; su vida misma [...] no merece el mismo respeto que la de los individuos que forman los otros grupos sociales blancos, mestizos, y aún negros (Castro Pozo [1924] 1979: 85).
}

Pero los prejuicios de los costeños y mestizos no constituyen el eje de la crítica. El ensayo denuncia el sistema de producción de las grandes haciendas que, por su tradicional organización del trabajo, sumerge al indígena en la inferioridad que provoca la explotación extrema. El latifundio es una institución de poder que activamente atenta contra el indígena, apropiándose de las tierras comunales, con niveles de violencia que llegan incluso al asesinato masivo: "Las mejores tierras de producción han pasado a poder de los terratenientes [...] la lucha por aquellas en los departamentos del Sur ha llegado hasta el extremo de eliminar al poseedor indígena por la violencia o masacrándolo" (Castro Pozo [1924] 1979: $302)$.

Haciendo sistema con la denuncia del latifundio, afirma con agudeza que las representaciones que circulan sobre el indígena están marcadas por la posición de poder que tienen los hacendados, aspecto que resulta evidentemente preponderante en el presente de enunciación del ensayo:

Los conceptos que respecto a los indígenas corren en informes y otros documentos oficiales, por lo regular, adolecen del grave error de ser autorizados por los latifundistas y otros interesados en que desaparezca la pequeña propiedad comunal, por lo cual debe tenerse sumo cuidado al consultarlos (Castro Pozo [1924] 1979: 78).

Por ende, Castro Pozo se sitúa claramente como una voz científicamente autorizada para el análisis socio-cultural del otro, desde una perspectiva objetiva, fuera de todo involucramiento 
con la ideología de los grupos oligárquicos, en sintonía con la primera etapa de la "La Patria Nueva". El indígena se encuentra en una situación de inferioridad no en virtud de determinaciones raciales o étnicas, sino como consecuencia de un abanico de causas, entre las que el latifundismo es preponderante, porque oprime al indígena y merma su capacidad laboral. Según dice, hay "una notable diferencia entre el trabajo libre del bracero indígena y el efectuado, quizá por éste mismo, bajo la vigilancia de un mayordomo o capataz" (Castro Pozo [1924] 1979: 52-53). Desestima el mal concepto que los hacendados e ingenieros tienen del "esfuerzo mecánico o racional que un bracero indígena es capaz de realizar en un día de labor: el indio en el trabajo libre -tarea o destajo- en nada es inferior a otros obreros" (Castro Pozo [1924] 1979: 40). Para Castro Pozo, las comunidades pueden "pulverizar el latifundio" como unidad productiva. Veamos cómo representa al indígena en la labor comunitaria:

En el trabajo en común llevado por su agente, en presencia de sus compañeros, de la mujer a quien pretende y de los padres a que han de prestar su asentimiento para que se unan; oyendo el quejumbroso huayno que deslíen en el ambiente el arpa y los violines, recordándole que trabaja entre los suyos, casi recreativamente y en condiciones de zapatear una danza por esos andurriales; el indígena comunero o, mejor dicho, la parcialidad que presta sus servicios en esta forma, desarrolla el máximo de sus energías psico-físicas y trabajos que pudieran realizarse, con igual cantidad de jornaleros, en determinado tiempo, ellos lo efectúan en un menor número de días de labor y a entera satisfacción del favorecido con aquella./ La energía, perseverancia e interés con que [trabaja un comunero en la minga, contrasta con] la desidia, frialdad, laxitud del ánimo y, al parecer, cansancio, con que prestan sus servicios los yanaconas, en idénticos trabajos u otros de la misma naturaleza; que a primera vista salta el abismo que diversifica el valor de ambos estados psico-físicos (Castro Pozo [1924] 1979: 40).

La comunidad es representada como un ámbito de armonía social, donde el trabajo es atravesado -e incentivado- por la presencia de familiares y seres queridos, en un ambiente festivo, cargado de música. A un paso de bailar, la comunidad da el máximo de su energía física y mental, mostrando una capacidad laboral en extremo eficiente.

El trabajo comunitario optimiza el rendimiento indígena -tema obsesivo del ensayo-: incrementa su productividad, y despliega al máximo sus capacidades intelectuales y físicas, disminuyendo el tiempo requerido para tareas que, cuando se realizan bajo las formas tradicionales como el pongaje, el yanaconazgo o la mita, propios del latifundio, llevan más tiempo y arrojan resultados más pobres, y con un costo más bajo:

En mi concepto, el indio es el mejor elemento de producción que poseemos y la única base posible para construir nuestra nacionalidad; por lo que la República está obligada a educar al indio levantando su nivel moral y cultural al mismo valor que el de las poblaciones costeñas, habituarlo al trabajo continuado y paciente en las escuelas agrícola-industriales que al efecto se establezcan en las diversas regiones del pais y, sobre todo, enseñarles prácticamente a aprovechar los recursos naturales de sus terruños, a fin de que por medio de 
su explotación o manufactura se enriquezcan y lleguen a desempeñar el rol que en las diferentes actividades republicanas les está reservado (Castro Pozo [1924] 1979: 311-312; cursivas nuestras).

La cita anterior es una buena síntesis de la valoración del indígena que se despliega en Nuestra comunidad indígena. Evidenciando el plan del autor, se lo considera como "el mejor elemento de producción" que hay en Perú. Promueve así su integración como fuerza de trabajo barata y de buena calidad para la producción nacional, lo que no difiere de propuestas como la de Valcárcel o Ernesto Quesada. Esa integración, no obstante, es acompañada de un proyecto que atiende a la salud psico-social del indígena; le provee educación moral y técnica, y fortalece su fusión - una vez removidos los escollos de su visión del mundo- con los demás sectores sociales que conforman la nación, para lograr la deseada modernización de las comunidades. Este último proceso está pensado a partir de la representación de un caso exitoso: la experiencia de la comunidad de Muquiyauyo, que será retomada extensamente por Mariátegui en sus Siete ensayos.... Muquiyauyo es descripta por Castro Pozo como "el prototipo" de organización comunal (Castro Pozo [1924] 1979: 52):

El estudio comparado de la organización comunal de Muquiyauyo con la de otras parcialidades del mismo o diferente departamento, arroja la convicción de que en aquella se han conservado, en toda su plenitud, las normas y prácticas institucionales de los ayllus-agrícola-ganaderos, que ya quedan estudiados, y alguno de éstos, con el sentido de la realidad y practicismo más acabados se han adaptado, no solo a las necesidades de la vida contemporánea de otros pueblos sino que han llegado hasta acaparar una gran parte de la actividad comunal, viniendo instintivamente a realizar una serie de obras y acciones que no serían capaces de llevar a cabo nuestros pueblos costeños. Tal sucede con la transformación que ha sufrido la finalidad del tesoro común erogado por todos y antaño dedicado a la celebración de fiestas, misas o pago de honorarios, ha llegado a constituirse en reserva de las instituciones de crédito y otras industriales que se están iniciando y hay la precisa convicción de que llegarán a feliz resultado (Castro Pozo [1924] 1979: 54; cursivas nuestras).

Como podemos observar en el párrafo citado, la representación positiva de la comunidad se acentúa a medida que se acerca a las prácticas productivas modernas al interior del capitalismo como finalidad (financieras crediticias y productivas industriales). El aporte del ayllu es remitido a los desarrollos sobre la modalidad tradicional de trabajo indígena comunitario. Además, como veremos, la conjunción de estas prácticas ha redundado en el positivo arribo de la comunidad a la vida contemporánea, antes ubicada conceptualmente por el autor en una temporalidad simultánea premoderna en que, para Castro Pozo, se encuentran gran parte de los indígenas del presente de enunciación del ensayo, consideración que allí se articula con la presencia de ideologemas evolucionistas. El autor valora, desde una 
perspectiva afín al higienismo cultural, la eliminación de los festejos en pos de la maximización racional de los bienes comunitarios.

Las cualidades magníficas de este "prototipo de comunidad" residen en su carácter de cooperativas de producción, consumo y crédito, que los ha acercado al progreso material moderno, logrando energía eléctrica propia para el alumbrado y la alimentación de maquinarias, además de la producción de hermosos edificios que opacan -desde los valles del Río Mántaro- la belleza de la ciudad, capital de la provincia de la costa norte de Perú. Castro Pozo pondera, desde una posición pragmática, el ahorro en el costo laboral que significa el trabajo indígena en la festiva minga (término de origen precolombino con el que se designa la tradición precolombina de trabajo comunitario o colectivo voluntario, con fines de utilidad social o de carácter recíproco), destacando incluso el trabajo femenino y el infantil:

Enorme, magnífica e inmejorable cooperativa de crédito cuya constitución íntima tiene el prestigio de una institución milenaria que ha llenado su objeto y es susceptible de adaptación a las normas del progreso, en ella están íntimamente ligados los principios que debieran poseer las modernas organizaciones de cooperación, y como no es única por la casta, la organización o la disciplina, su progreso es un ejemplo y un símbolo: las innumerables comunidades de nuestras serranías bien pronto se convertirán en cooperativas de producción y de consumo, forma y sustancialidad capaces de pulverizar los grandes latifundios y resolver el problema agrario de esta zona./ Por hoy la parcialidad de Muquiyauyo presenta los caracteres de las cooperativas de producción, consumo y crédito, en sus diversas funciones, a las que han de agregarse las que por su misma naturaleza le corresponden./ Dueño de una magnífica instalación o planta eléctrica en las orillas del Mantaro, por medio de la cual le proporcionan luz y fuerza motriz, para pequeñas industrias [a otros distritos] se ha transformado en la institución comunal por excelencia; en la que no se han relajado sus costumbres indígenas y antes bien han aprovechado de ellas para llevar a cabo la obra de la empresa; han sabido disponer del dinero que poseían empleándolo en la adquisición de grandes maquinarias y ahorrado el valor de la mano de obra que la parcialidad ha ejecutado lo mismo que si se tratara de la construcción de un edificio comunal: por mingas, en las que hasta las mujeres y niños han sido elementos útiles en el acarreo de los materiales de construcción [...]/ Ni Jauja, que es la capital de la provincia, posee tan hermosos edificios como aquel. Los Muquiyauyinos se enorgullecen de haber alcanzado una piedra o un poco de barro para su construcción (Castro Pozo [1924] 1979: 55).

Este párrafo contiene el eje central del proyecto social y económico de Castro Pozo para las comunidades: competir y "pulverizar" el latifundio, mediante la más eficiente organización cooperativa comunitaria indígena. La centralidad que toma la cooperativa, como ganadora de un modelo de economía mixta, es un dato particular del ensayo, ante la más indefinida medida sugerida por otros indigenismos, de integrar al indígena como fuerza de trabajo en el marco de la modernización económica de Perú. La combatividad contra el latifundio no se articula con la consideración de la propiedad de la tierra, tema que queda silenciado en todo el ensayo. 
De la celebración de la comunidad de Muquiyauyo, se pasa rápidamente a la preocupación por la situación "de la masa popular-comunal":

La comunidad de Muquiyauyo es un modelo de comunidades, cuya organización [...] refieren al estricto cumplimiento de las obligaciones de cada comunero./ Los vicios -alcoholismo, cocaísmo y otros- desgraciadamente no han desaparecido, y en la masa popular-comunal se ve el estrago que causan dichas calamidades; pero nunca he presenciado las enormes e inauditas borracheras que en Huancayo, en la que parece que toda la indiada -en los feriadosse hubiera alcoholizado y tambaleante camina, arrastra o ronca hecha un marrano en los charcos de sus calles (Castro Pozo [1924] 1979: 56).

El alcohol y la coca han causado estragos en los indígenas, afirma Castro Pozo, quien examina detenidamente esa cuestión desde puntos de vista médico-positivistas, en los que el énfasis sobre la higiene y la salud física y psíquica de la "masa" indígena obstaculiza la llegada al estándar productivo que marca ese "modelo de comunidades" que es la comunidad de Muquiyauyo. La situación -en la que la masa indígena termina convertida en cerdo- es ubicada en la misma provincia en que se encuentra Muquiyauyo, hecho que parece atribuir un sentido de lucha en desarrollo en el presente de enunciación del ensayo, en la que el pasado y el presente/futuro se están combatiendo, y que requiere la intervención científica del intelectual, para conducir ese estado de cosas hacia metas de progreso civilizatorio.

Antes de cerrar el análisis de las representaciones imaginarias de la comunidad, para adentrarnos en los diagnósticos patológicos sobre la alteridad indígena, es importante remarcar la no adscripción de Castro Pozo al paradigma "incaísta". Por el contrario, representa la comunidad como un actor social históricamente oprimido por poderes centralizadores, entre los que incluye a los Incas, a diferencia de otras modulaciones indigenistas que se centran en la Conquista, la Colonia y la República peruana. El indígena es un

...pueblo moldeado en este medio donde, por su especial condición topográfica, se produjo la cruda autocracia del curaquismo, que sufrió desde sus albores; el Imperio castró sus energías individuales segando sus fuentes de progreso y bienestar familiares, la cruenta ambición de la Colonia lo arrastró hasta el sacrificio de su vida en los obrajes y las minas y nuestra República, menos venalmente que ésta pero con mayor saña, hasta la fecha, no ha hecho otra cosa que explotarlo, arrebatarle sus tierras y reducirlo a la inclemencia de la puna y a la dura condición de esclavo o siervo en las [tierras] que fueron y continúan siendo de su legítima propiedad (Castro Pozo [1924] 1979: 220).

La disputa con lo inca puede vincularse con la procedencia regional de Castro Pozo, la costa norte de Perú, área donde Max Ulhe y Ruth Shady descubrieron objetos arqueológicos de 
períodos previos a los Incas, y que las expediciones de Julio C. Tello ampliaron al reconocimiento de la cultura chavín, cuyos motivos estéticos también formarán parte del indigenismo estético oficial "neoperuano" (Ramón, 2014: 41). Esta consideración sugiere un posicionamiento desde el nacionalismo regionalista costeño, en la disputa de las élites centralistas por la representación del indigena, resistente al incaísmo de los intelectuales de Cusco, pero también a la línea de la estética nacionalista oficial.

\section{La lente y el escalpelo en el viaje hacia el otro}

Como vimos en el apartado anterior, en el ensayo, Castro Pozo apela por momentos al telurismo como clave de lectura, hecho que repone en sordina el binarismo costa-sierra, pero que también opera como plafón para la crítica del indígena, que se articula con la auscultación positivista.

El ensayo plantea que el medio es una causa de peso en la negativa configuración del carácter indígena. En esto no resulta menor el mencionado origen costeño del autor, que escribe desde Lima: en los debates con los intelectuales del interior, la negativización del paisaje serrano y su extensión a las poblaciones es un argumento frecuente. Al menos hasta el año 1927, donde la salida de Tempestad en los Andes, de Amauta y de otras revistas como La sierra operan una suerte de inversión en la valorización del binomio costa-sierra. Para el autor, el medio serrano determina, en primera instancia, el carácter deficiente de los pobladores, ya que se halla

...constituido por la enorme puna [y] por las gigantescas y graníticas moles andinas, a cuya presencia el alma se anonada y enmudece porque la hoscosidad [sic] y acromatismo del paisaje solo despiertan en ella el sentimiento de su propia pequeñez e impotencia y el amargo sabor $\mathrm{o}$, si se quiere, la tristeza de quien está convencido de su esclavitud y de que serán vanas todas sus energías para libertarse de aquella (Castro Pozo [1924] 1979: 219).

Y también:

[La amargura es] el estado sensitivo normal del indio, amamantado con la leche gris de los claroscuros paramosos de las punas y cerros [...]. Raza vencida por el medio físico, al que no ha tenido con qué, ni tiempo para domar y avasallada por la inhumanidad del hombre que se adueñó los más valiosos recursos de nuestros pueblos (Castro Pozo [1924] 1979: 220). 
Castro Pozo compone así un paisaje avasallante por su enormidad. Pesado, gris, filoso, da la sensación de que aplasta a sus pobladores, a quienes - no obstante- da el pecho como a un hijo. Los indios en consecuencia son faltos de voluntad y esperanza, hecho que comienza a preparar el terreno para la intervención heterónoma del intelectual y del Estado.

En las últimas oraciones de la cita anterior, podemos observar que el determinismo geográfico es complementado por un argumento histórico. Como consecuencia del medio, el indio de las comunidades ha sido siempre "vencido". Esa historia se piensa, complementariamente, desde una perspectiva darwinista que introduce la "lucha por la vida", como dinámica a través de la cual se ponen en contacto los grupos étnicos, opacando cualquier sentido histórico y social sobre el lugar indígena en esa lucha: "Al medio físico que deprime y determina en la raza sus diversas modalidades, hay que agregar la lucha desigual y despiadada que aquella ha tenido y tiene que soportar con los otros grupos étnicos (Castro Pozo [1924] 1979: 219; cursivas nuestras). La comunidad indígena es representada entonces, dada la determinación negativa del medio geográfico, como una agrupación oprimida desde sus orígenes. Entonces, la sociología biológica y el darwinismo social marcan la presencia de las coordenadas epistemológicas del positivismo evolucionista sobre el que se posiciona el autor.

La religiosidad popular, en general, resulta el elemento más peligroso de la subjetividad indígena, porque se supone que agrava las tendencias patológicas de los individuos y dispersa su energía productiva -la cual puede ser catalizada por movimientos religiosos mesiánicos contra el sistema, y desencadenar atentados contra el orden capitalista, como lo indican Riva Agüero en Carácter de la literatura del Perú independiente (1905), José María Ramos Mejía en Las multitudes argentinas (1899) para el contexto argentino, o Euclides da Cunha en Los Sertones (1902) y Nina Rodrigues en su producción de las últimas décadas del siglo XIX para el contexto de Brasil-. Al reponer los ideologemas clisé de la psicología de las multitudes y la psiquiatría de fines del siglo XIX, Castro Pozo hace foco en el peso de la superstición y de la religión en la subjetividad indígena, así como también en el correlato de las posibles recaídas en liderazgos tradicionales.

Aún cuando se pone en consideración -sociológicamente- el peso de instituciones como el latifundio o la Iglesia Católica en el entramado de relaciones que determinan la situación de inferioridad indígena, la aseveración de que los efectos del poder convergen con las patologías de la subjetividad indígena prolonga la re-emergencia del dispositivo médico-positivista -articulado, como dijimos, con el imaginario del socialismo liberal 
decimonónico-. Ese dispositivo analiza las supersticiones, los hábitos de higiene moral y cultural, la criminalidad, la barbarie, e incluso la caída en la animalidad y la incultura. Castro Pozo muestra cómo la religiosidad interrumpe las prácticas productivas:

Los tres primeros días de luna nueva, así como en los de media luna y luna llena abandonan toda clase de trabajos agrícolas por el hecho de que la semilla no "agarra" o se mutan los valores idiosincráticos de su naturaleza; las "lapas", por ejemplo, producen "mates" y las "limetas", "purus" o calabazos pequeñitos; el maíz, la quinua y las papas no crecen "como de costumbre" y su cosecha es insignificante; amén de que están expuestas a las gusaneras y otras plagas que arruinan dichos sembrados. Otro tanto sucede cuando los productos pequeños se siembran en luna llena: "las plantas se van en hojas" y sus productos resultan deformes. Una completa alteración de las leyes biológicas (Castro Pozo [1924] 1979: 151).

En el ejemplo citado, la religiosidad de la subjetividad indígena es un obstáculo para la producción, dado que, por ejemplo, las creencias sobre el peso de las fases de la luna sobre la naturaleza interrumpen los trabajos de agricultura. Las creencias originarias, dado su carácter vinculado a la muerte, dan centralidad a prácticas y creencias que van en contra de las técnicas productivas modernas. Otra vez los ritos originarios, dada su larga duración, fragmentan permanentemente el tiempo productivo de las comunidades, haciendo del indígena un trabajador inconstante.

De todos modos, la religiosidad popular es concebida sincréticamente como la combinación de las creencias católicas y de las originarias -y aquí ambas son criticadas, ya que el anticlericalismo del ensayo tiende a separar lo católico de lo occidental positivamente connotado-: son "supersticiones y leyendas de carácter religioso que actualmente integran la conciencia moral de estos pueblos y que, en la mayoría de los casos, constituyen la causa fundamental de sus decisiones y peculiar modo de ser" (Castro Pozo [1924] 1979: 165). La psicología indígena configura un mundo poco productivo, fundado en la irracionalidad, que disminuye la capacidad de trabajo del indígena.

En la representación de Castro Pozo, el indígena cae bajo la influencia de párrocos, brujos y curanderos, principales meneurs que irradian las ideas religiosas y las supersticiones que incentivan su sugestión. El ensayo expresa la preocupación, en consonancia con la psicología de las multitudes de entresiglos, por la continuidad entre sugestión religiosa y sugestión política, en manos de los caudillos de la política tradicional. ${ }^{66}$

\footnotetext{
${ }^{66}$ Para un análisis de la lógica discursiva y las prácticas intelectuales vinculadas a la psicología de las multitudes como disciplina positivista, ver Laclau (2005). Para el caso latinoamericano, ver Mailhe (2010).
} 
La influencia que había comenzado a ser política, ahora retorna a su forma religiosa, premoderna. Las referencias al caciquismo político son más laterales, y emergen en torno a las denuncias contra la política tradicional de la "República Aristocrática", en sintonía con los discursos reformistas que también son parte del imaginario leguiísta en su primer período populista. Castro Pozo parece recuperar los argumentos de la tradición intelectual que pensó la "política criolla" en Perú, tal como vimos en el primer capítulo de esta tesis, al abordar el ensayo de Francisco García Calderón Las democracias latinas de América (1912).

El carácter sugestionable del indígena es marcado insistentemente por Castro Pozo. En varias ocasiones representa a estos sujetos cayendo en estado de sugestión colectiva. Por ejemplo, durante la ceremonia matrimonial comunitaria, promovida por la iglesia católica, subraya cómo ésta produce, entre los asistentes, una suerte de compulsión por casarse para tener relaciones sexuales:

La sugestión del grupo es tan completa que parece que toda la comunidad se enfermara de celo. $\mathrm{Y}$ así he tenido ocasión de presenciar un curiosísimo caso en que los matrimonios se contrataban "caliente caliente" y avanzaba la pareja al grupo de los que aguardaba la bendición y se enfilaba entre ellos con el propósito de casarse (Castro Pozo [1924] 1979: 105).

Otra caída en estado de multitud se da en torno a las ceremonias de entierro, cuando los indígenas, estimulados por el alcohol, se convierten en un coro exaltado que pasa del rezo compungido a la risa "diabólica":

Si el alcohol no fuera el agente primordial de estos sentimientos enfermizos [...] y en cada rostro lo ridículo no imprimiera el germen de sus diabólicas carcajadas, este acto resultaría más sentido e imponente que el del entierro; pues casi todos gimotean, cantan fúnebremente o lanzan exclamaciones llenas de tristeza y desconsuelo, hasta que llegan a la casa mortuoria donde se inicia el rezo de por noche (Castro Pozo [1924] 1979: 127).

Con criterio cientificista, el autor intenta dar una explicación secular acerca de los fenómenos supersticiosos que narra. Para ello se ubica en algunos lugares comunes de la psiquiatría de entresiglos. Así por ejemplo, cuando trata de explicar el "mal de ojo", como producto del "hipnotismo", coincidiendo así con la mayoría de los discursos medicalizadores de la religiosidad popular, señala que "he tenido oportunidad de presenciar innumerables casos de 
esta naturaleza en los cuales, aparentemente, no existía otra causa que generara dicha enfermedad; por lo que me inclino a creer que ella es debida al hipnotismo animal involuntario" (Castro Pozo [1924] 1979: 201).

Asimismo, al abordar la viruela como enfermedad, el autor cuenta cómo los indígenas creen que, para prevenirse de ese mal, hay que visitar la habitación del muerto y tomar sus ropas. Por ende, las creencias no hacen sino favorecer el contagio. "Compréndese ahora [dice] el porqué de la rápida propagación de esta epidemia [de viruela] en los pueblos serranos y la necesidad ineludible de civilizarlos cuanto antes" (Castro Pozo [1924] 1979: 210).

Como podemos ver, la mirada médico-científica -que condena las prácticas religiosas y las supersticiones populares- forma parte del dispositivo normalizador en sentido civilizatorio que recorre todo el ensayo, explícita o implícitamente. Hay también otros intentos del mismo tenor, que revelan un énfasis en la psicología experimental de base biológica claramente pre-freudiana, como esta explicación de un caso: "Por los estudios que he hecho de esta enfermedad en un indio de Huacrapuquio y los datos que he podido conseguir respecto a otros enfermos que murieron del mismo mal, deduzco que se trata de neurastenia, cuyo proceso se determina fatalmente, en una congestión cerebral" (Castro Pozo [1924] 1979: 198).

La brujería indica la presencia todavía deficiente de la ciencia médica, aunque Castro Pozo no la descarta en bloque, ya que en algunos aspectos prefigura la medicina moderna, o al menos puede coexistir, si no complementarse, con ella. De hecho, repitiendo un lugar común de los estudios científicos sobre superstición en la época, advierte que la psiquiatría ha probado la eficacia de la brujería en los casos en los que la patología es provocada por la sugestión. Lo mismo ocurre con las fiestas católicas, con el agravante de que son impulsadas con fines de lucro por parte del clero católico de las comunidades. ${ }^{67}$

Por último, la influencia del cristianismo se condena en todo el ensayo, pero contradictoriamente se piensa como "civilizatoria", porque borra la lengua y las creencias originarias: "Las misiones eclesiásticas han progresado mucho, obteniendo resultados asombrosos en cuanto al olvido del idioma nativo y la degeneración de sus costumbres" (Castro Pozo [1924] 1979: 100). Curiosamente, Castro Pozo valora la expansión del idioma nativo, pero condena la cosmovisión indígena; es decir; secciona el continuum de las

\footnotetext{
${ }^{67}$ Tal es el caso, por ejemplo, del indigenista francés en Argentina Henri Girgois. Al respecto ver Mailhe (2021).
} 
prácticas culturales del otro social, y decide (guiado por el racionalismo cientificista, y por un evolucionismo reformista y laico) incorporar algunas prácticas y excluir otras como inviables, como escollos para el progreso nacional.

Las representaciones más negativas del indígena, contenidas en el ensayo, emergen en los momentos en que se abordan escenas que ocurren fuera de las reuniones comunitarias o "mingas". Al retratar, por ejemplo, al indígena en familia, se acentúa la patologización de la alteridad, desplegándose una mirada fuertemente miserabilista. La metodología de Castro Pozo consiste en analizar instituciones y prácticas de la vida del indígena, para luego presentarlas como objetivaciones de su "alma". De ese modo, el estado de la familia indígena -dividida, enfrentada, falta de solidaridad- aparece como un reflejo del carácter indígena que lo conduce al fracaso moral y material:

\begin{abstract}
El hogar indígena es la institución que menos ha evolucionado o sufrido modificaciones en los pueblos comuneros; es como el centro y fuente donde se conservan y generan los recuerdos, instintos y costumbres de la comunidad, es siempre el mismo. Hasta sus umbrales llegan los embates de la civilización que a medias poseemos y en ellos agonizan, como las olas, cansados, sin energía para traspasarlos y vivificar aquel sepulcro donde se pudren las energías de la raza, se ha apagado el altar de lo que ha sido y se vegeta una vida rutinaria cuyo ideal se ha proscrito y el triunfo y la audacia, sus más valiosos atributos, se han dormido en las faldas pergaminosas de los momiescos "auquillos" (Castro Pozo [1924] 1979: 57; cursivas nuestras).
\end{abstract}

La figura de la tumba es utilizada por el autor para representar el hogar indígena. En ese espacio impermeable a la "civilización" - una fortaleza de piedra que preserva la barbariemueren la potencia, la voluntad y la temeridad que en algún momento los indígenas habrían tenido. El autor, apelando a una escritura donde la sintaxis impersonal parece resultar cómoda para el borramiento de la responsabilidad de los sectores dirigentes, y para la dilución de la dominación, representa el hogar indígena como un ámbito -literalmente- lleno de humo de excremento, lo cual genera una atmósfera irrespirable. La miseria material de la construcción, del mobiliario y de los utensilios domésticos es tomada como un indicador de la miseria moral. 
Es interesante remarcar la condición civilizatoria "incompleta" que Castro Pozo le atribuye a Perú, que vuelve aún más negativa la situación de los indígenas, quienes no alcanzan ni siquiera esa "media" evolución. Veamos:

\begin{abstract}
Desconocen la comodidad de las mesas, sillas y bancos; cada cual se sienta en los talones o en cuclillas, y cuando están comiendo es de verlos [sic]: tal que si fuera un grupo de pingüinos con el plato o el mate en la mano, hieráticamente zambullidos entre las densas humaredas que despide la "bosta", pues ya queda dicho que cocinan con este material./ Es indudable que el uso de estos objetos, mesas y sillas por la familia acusa un alto grado de sociabilidad que los pueblos primitivos -como nuestras comunidades- están muy lejos de poseer. La movilidad de los asientos, la relativa facilidad con que se trasladan de un sitio a otro ha traído como consecuencia el esparcimiento familiar. Nuestros indios comuneros con poyos arraigados al suelo y las paredes de sus casuchas han inmovilizado su espíritu y, mentalmente, se han vuelto aún más perezosos que físicamente; por eso no les gusta conversar ni reír del prójimo -como nosotros- y prefieren estar solos, ¿contemplando? la desnudez de los cerros, casi en un estado semicomatoso y estúpido que fácilmente los conduce a la idiotez (Castro Pozo [1924] 1979: 62; cursivas en el original).
\end{abstract}

En los momentos más radicalmente peyorativos del diagnóstico, el indígena es animalizado ("un grupo de pingüinos") y se lo acerca además a la condición de un enfermo en coma, llegando al extremo de presentarlos como "estúpidos" e “idiotas". La contemplación, como pregunta, revela la incorporación irónica de la voz agonal del indigenismo, que Castro Pozo desmiente, "desnudando" el verdadero retraso material y moral encubierto bajo la máscara de la contemplación.

La atribuida condición de idiotas no exime a los indígenas de ser sujetos potencialmente peligrosos, que pueden llegar a cometer algunos de los crímenes más deleznables:

En algunas comunidades la fiereza y amoralidad son tales que hasta se cometen crímenes inclasificables [de hijos contra sus progenitores], como el de matar a palos a una pobre mama, destrozar su cuerpo, meter en un saco estos miembros palpitantes e ir a arrojarlos a un despeñadero (Castro Pozo [1924] 1979: 58; cursivas en el original).

Este relato parece evocar la narrativa de Enrique López Albujar, quien despliega, en cuentos como "Ushanan Jampi", una mirada criminalizadora y patologizante del indígena y de la comunidad que ajusticia en estado de multitud. En la cita anterior, los detalles escabrosos del matricidio -la muerte a palazos, el descuartizamiento, los miembros palpitantes- bloquean toda posibilidad de empatía del lector con unos sujetos indígenas que pierden radicalmente su dejo de humanidad. Peligrosos y deshumanizados, los indios que produce la familia indígena 
son enfermos y viciosos desde la infancia. Castro Pozo atribuye esto al hecho de que el vínculo inicial no está formado por el amor, sino por el más inmediato deseo sexual, entre sujetos precoces, sexualmente inmaduros. ${ }^{68}$ De allí que los niños que son fruto de esas uniones sean criados con desidia, al punto de darles alcohol para calmarlos, iniciándose así tempranamente en una vida de excesos:

La familia comunal, teniendo por base los apetitos carnales del instante o las conveniencias familiares, es la institución más desgraciada que conozco, pues a más de su inconsistencia o deleznabilidad sufre la impotencia de sus miembros para la generación sana y robusta, ya que en los matrimonios prematuros los niños o adolescente no están capacitados fisiológicamente para la fecundación. Y si se agrega a todo esto el alcohol y la coca, el alcohol, sobre todo que aprenden a tomar desde que tienen meses de nacidos - pues las madres, como queda referido, los crían el "quipe" y a fin de que no lloren les dan las sobras de las copas que liban o empapan uno de sus dedos en "Chaccta" y así les echan gotas de licor en la boca- ya será fácil formarse una idea de la degeneración a que marchan estos pobres seres y la suerte que les está reservada a estos pueblos, si el Estado no se preocupa de educarlos y mejorar su condición (Castro Pozo [1924] 1979: 107).

Frente a estos sujetos indígenas tan devaluados, el autor pide manifiestamente la intervención del Estado. Vicios, violencia y promiscuidad son atributos que activan todo un legado de temores, y encienden la alarma de la "amenaza indígena" ante la vida y la moral burguesas. Reponiendo una vez más las preocupaciones higienistas del socialisimo liberal -en términos de salud tanto física como psicosocial-, Castro Pozo denuncia el carácter lascivo de la familia indígena. Las representaciones exacerbadas que acompañan el tratamiento de esta cuestión introducen temas revulsivos como el incesto, componiendo así un cuadro en donde lo indígena es llevado a un nivel superlativo de estigmatización:

La promiscuidad en que duermen en una cama común, sin distinción de edad ni sexo y con los perros de la casa, la poca o ninguna preocupación de los padres por el cuidado de sus hijos, contribuyen a que éstos, desde su más tierna edad, despierten la precoz sensualidad de la raza y adquieran, en pleno florecimiento de la vida, el tipo lacio, pensativo, huraño, retraído y bilioso que se observa en la mayoría de los niños indígenas de la parcialidad (Castro Pozo [1924] 1979: 66).

\footnotetext{
${ }^{68}$ El autor considera que el carácter arreglado de los matrimonios, y la Iglesia católica, funcionan como verdaderos obstáculos para la formación de la sociedad conyugal: "[La] inconsistencia o deleznabilidad de la familia indígena tiene como causales poderosas, principalmente, estos casamientos en masa [llevados a cabo por la Iglesia]; en que no se valorizan las condiciones de los contrayentes" (Castro Pozo [1924] 1979: 106); "la ausencia de todo cariño y aliciente en la vida de este hogar sin lumbre ni respeto filiales, influye para que los hijos lo abandonen desde la más tierna edad" (Castro Pozo [1924] 1979: 58).
} 
El autor sugiere que los niños indígenas adquieren una sexualidad precoz y patológica por compartir el lecho con los adultos, con los otros niños de la familia e incluso con animales de la casa, hecho que determina un carácter antisocial desde temprana edad. La sexualidad en los niños es un tema obsesivo desde el positivismo de entresiglos. El registro de las diferencias culturales frente a la sexualidad patologizada de las alteridades sociales es de particular interés para la antropología, que busca conocer estas prácticas y exponerlas para reprimirlas en el marco de la construcción de las naciones modernas (De Certeau: 1999). No obstante, el autor insiste una y otra vez en tocar este tema, al que le atribuye las causas de la “degeneración” indígena: ${ }^{9}$

En las escuelas y colegios he podido observar que de cuatro a cinco años ya parecen mundanos y son tan maliciosos como los mayores./ Y esta es una evidente prueba de degeneración; el raquitismo indígena, en algunas comunidades, es debido en gran parte a este desarrollo forzado y prematuro de las funciones genésicas (Castro Pozo [1924] 1979: 107).

También la mujer indígena condensa representaciones negativas, aunque recibe un tratamiento ambiguo. Por un lado, Castro Pozo la define como "somnolienta y perezosa", como "taciturna" pues "no piensa en nada", implicando así un bajo grado de "potencialidad intelectiva" y/o de capacidad de abstracción. Incluso, señala que se han extinguido sus deseos y pasiones (Castro Pozo [1924] 1979: 72-75). Al mismo tiempo, en algunos pasajes el autor la presenta como una víctima de la institución familiar comunal, y denuncia su explotación doméstica, sugiriendo incluso su tratamiento como un bien que puede venderse o intercambiarse. ${ }^{70}$

A pesar de la afirmación de Castro Pozo, respecto de que es posible conocer el "alma indígena" y de la comunidad a través de la indagación de los elementos que componen su religiosidad, y acercarse etnográficamente a la alteridad aprehendiendo la profundidad del sujeto, el autor de Nuestra comunidad indigena pone ese conocimiento al servicio del

\footnotetext{
${ }^{69}$ Para un análisis de las operaciones patologizadoras de la alteridad social llevadas adelante por la antropología física en el contexto argentino de entresiglos, ver Perazzi (2009).

70 "Se la manda para que haga todos los quehaceres de la casa, que se le alquila o regala y con facilidad vende por una determinada cantidad, lo mismo que si fuera un objeto" (Castro Pozo [1924] 1979: 69; cursivas nuestras).
} 
desguace de su objeto de estudio, cuyas prácticas circularán en adelante fragmentadas y resignificadas. Si para el indígena toda la experiencia del mundo se halla cargada de sacralidad -dado que la religión no constituye una instancia separada de la vida cotidiana y de la naturaleza-, el ensayista se esfuerza por diferenciar ambas esferas, en consonancia con la visión secularizadora de la modernización capitalista, desplegando una violencia simbólica por momentos extrema.

Como en el positivismo de entresiglos (teniendo en cuenta desde los ensayos médico-legales sobre la alteridad afro de Nina Rodrigues, en Brasil, hasta la recolección de supersticiones, en la zona del Río de la Plata, por parte de Daniel Granada en Reseña histórico-descriptiva de antiguas y modernas supersticiones del Río de la Plata, de 1896), en el texto de Castro Pozo, la minuciosidad en el registro de las prácticas populares apunta a clasificar y luego a evaluar qué puede conservarse (en los campos de la lengua, la medicina, las creencias, las supersticiones, la literatura y el arte) como elementos valiosos para crear un matiz de color local, y cuáles deben ser reprimidos por su carácter insalubre (en la doble dimensión física y psíquico/moral) y/o por su papel como escollos con respecto a la productividad modernizadora.

Esta perspectiva atraviesa no sólo las prácticas que afectan a la producción, sino también las disputas por los aportes del folclore como reserva de la identidad nacional: las prácticas de los grupos populares más atrasados son registradas obsesivamente por las elites intelectuales de los diversos nacionalismos culturales. Hacia 1930, este método será sistematizado teóricamente en Argentina por José Imbelloni en Concepto y praxis del folclore como ciencia (1943), considerando el folclore como una parte importante de la antropología científica.

\section{Cortar, seleccionar, depurar e integrar:}

las industrias artesanales comunitarias y el folclore nacional

Una vez controladas y seleccionadas por el intelectual, las prácticas supersticiosas ingresan, ya secularizadas, desarticuladas como creencias, vueltas mera literatura. Vale la pena recordar que la literatura y el arte son formas modernas, desacralizadas, occidentales, de resituar los restos de la espiritualidad indígena, en un gesto que será clave entre los primitivismos estéticos y antropológicos de las décadas del veinte y del treinta, pero que 
enraiza incluso en los movimientos estéticos pre-vanguardistas y en el neo-romanticismo de entresiglos. Acompañando este tipo de gestos, Castro Pozo silencia la violencia simbólica implícita en retirar el aura religiosa de los bienes indígenas precolombinos, para convertirlos en arte, en el sentido occidental.

Curioso resultaría hacer una recopilación sistemada de todas aquellas leyendas y cuentos indígenas que nos enseñarían la riqueza pictórica e imaginativa de la raza autóctona, y cuya enseñanza llevaría consigo la demolición de los prejuicios de inferioridad y degeneración con que signan a dicha raza quienes menos se han preocupado de estudiarla y comprenderla (Castro Pozo [1924] 1979: 287; cursivas nuestras).

Castro Pozo realiza aquí una importante operación teórica, que consiste en desactivar la cosmovisión, arrasar con su sacralidad y con la organicidad de una concepción religiosa del mundo, para reubicar creencias, leyendas y mitos (ya secularizados, occidentalizados y occidentalizables), en el campo del folclore literario, así como para convertirlos en bienes materiales, artesanías o temas y motivos estéticos. En definitiva, la operación reside en desmontar la cosmovisión premoderna y no occidental para fragmentarla, reificándola como mercancía. Depurar es el movimiento clave de la operación del ensayo sobre la visión del mundo indígena: desactivar lo resistente y reconducir lo que es aprovechable.

En cada campo Castro Pozo desarma y refuncionaliza, excluyendo los elementos inviables. Lo mismo sucede con el artesanado, el otro proyecto económico productivo para las comunidades indígenas que promueve Nuestra comunidad indígena: constituir industrias artesanales en algunas comunidades. En palabras del autor:

En la zona andina tenemos regiones productoras de cereales y otros artículos alimenticios a más que de materias primas para manufacturar que, con buenos caminos y medios fáciles y baratos de conducción, abastecerían todos los mercados de la Costa y aún dejarían margen a la exportación (Castro Pozo [1924] 1979: 312).

En Castro Pozo, la apuesta por conformar un artesanado comunitario conecta con una concepción de la producción artesanal indígena que, despojada de sacralidad, puede volverse mercancía. La producción de alfarería, cestería, utensilios de madera, tejidos de lana y de algodón, calzado y sombrerería, son elementos integrables a los mercados regionales nacionales y extranjeros, como productos de calidad. Cabe señalar que, en el ensayo, estos productos son considerados sobre todo por su valor utilitario, y no tanto por la marca estética de lo indígena, que se diluye. 
Castro Pozo calcula frecuentemente la productividad del trabajador comunero, para elogiar por ejemplo la gran dedicación del indígena alfarero: "Un buen obrero, trabajando de seis a ocho horas diarias, puede manipularse una docena y media de ollas pequeñas y, en el mismo tiempo, media docena de cántaros de regular tamaño o igual cantidad de cantarillas, con sus respectivos platillos" (Castro Pozo [1924] 1979: 337).

El autor releva con minuciosidad qué producen las comunidades, cómo lo producen y de qué modo lo consumen y/o lo comercializan. Clasifica los productos y analiza el proceso de producción de cada uno, describiendo detalladamente la productividad del indígena por jornada laboral. Castro Pozo propone mercantilizar la producción, con el costado de violencia simbólica que implica terminar de desarticular lo que reste de cosmovisiones no occidentales, y el costado positivo de conservar esas prácticas, ubicándolas como un posible eslabón en el mercado interno, e incluso en el mundial.

El autor muestra el prototipo de un producto de la industria artesanal comunitaria que tiene éxito internacional: el "sombrero cataqueño", modelo de producto inserto en el mercado mundial cuyo precio "fluctuaba [con] motivo de la inmensa demanda que últimamente ha tenido el sombrero en los mercados de Europa y Estados Unidos" (Castro Pozo [1924] 1979: 329). La producción de este panama hat peruano es valorada por ser una "industria familiar, netamente indígena de un enorme porvenir".

Castro Pozo se esfuerza en demostrar que las "industrias comunitarias" tienen un grado de desarrollo que les permite cubrir las necesidades de la comunidad, y generar un excedente para comercializar. No obstante, señala las limitaciones que impiden un mayor aumento de la producción, tales como la ausencia de división del trabajo, y el desconocimiento de técnicas y herramientas modernas:

La producción de dichas comunidades [...] ha sobrepasado el límite de sus propias necesidades y va adquiriendo, poco a poco, un desarrollo gradual y estimulado por la demanda y buen precio a que se cotizan sus productos, los cuales, según datos que tengo a mano, son los mismos y de idéntica calidad a los que obtienen los latifundistas (Castro Pozo [1924] 1979: 302).

Nuestra comunidad indígena parece tomar un camino similar al que tomará años después el Contrapunteo cubano del tabaco y el azúcar (1940) del cubano Fernando Ortiz, pues si en ese ensayo el tabaco es la vía de salida de los sectores populares, ahogados por el latifundio, aquí es la producción artesanal la vía de supervivencia que permite no tocar (o no tocar demasiado) el orden oligárquico de distribución de la tierra: 
Necesitamos redimir al indio y hacer que sus tierras produzcan el doble, que mejore sus ganados y se capacite para bonificar el pasto de sus punas; abrámosle caminos, caminos que pongan en relación estos pueblos con la Costa y entre ellos mismos; medios de locomoción que no encarezcan artificialmente los productos y centros de educación y enseñanza agrícolas en donde se capacite prácticamente a los agricultores comunales para extender e intensificar sus cultivos. He allí la política de mayor encomio y agradecimiento nacionales (Castro Pozo [1924] 1979: 313).

Sin embargo, se requiere la mejora de los elementos determinados por la subjetividad indígena que analizamos con anterioridad. En virtud de ello, los indios tienen -salvo en los "modelos de comunidad"-, niveles de producción no intensivos, y la mano de obra es también poco productiva. Esto ocurre porque los indígenas presentan una mentalidad no racional: no complejizan sus necesidades. No son maximizadores racionales, como Castro Pozo desea que sean.

$\mathrm{Su}$ propuesta es, en ese sentido, industrializar la producción artesanal y orientarla al modelo agro-exportador; convertir las comunidades en cooperativas de producción que, al insertarse económicamente en el mercado mundial, se incorporen culturalmente en la modernidad occidental, y que ello redunde en un beneficio mayor para los indígenas, generando un círculo virtuoso de "progreso". En efecto, el comercio es considerado como uno de los factores centrales para el mestizaje, elevado este al rango de proceso modélico para la evolución de la población peruana. En los pueblos costeños, bajo el influjo del medio,

...los conquistadores [...] llegaron a absorber toda la actividad comercial e industrial de [las poblaciones incaicas], así como sus primordiales energías étnicas y fisiológicas. Por esto, la población indígena costeña de los alrededores de las nuevas ciudades castellanas perdió la fisionomía histórico etnográfica de su organización en ayllus así como su natural e idiosincrático desenvolvimiento, que decreció notablemente constituyendo, en cambio, uno de los elementos básicos del mestizaje que, por razón de su propia naturaleza, socialmente, llegó a ser el intermediario entre aquella y el conquistador huiracocha. De donde los mestizos, aunando en sí los más opuestos caracteres de sus progenitores, llegaron a ser el medio en que se desenvolvieron las nuevas tendencias e instintos que en aquellos se generaron como producto de dos diversas civilizaciones, de las cuales una de ellas, la de los vencidos, no mereciendo de la raza conquistadora ninguna consideración, debía desaparecer (Castro Pozo [1924] 1979: 243).

Ese desarrollo de las relaciones capitalistas de producción, y la occidentalización cultural que va de la mano con la moral burguesa, son abordados en relación con otros dos elementos centrales del ensayo: la educación y la dinámica del mestizaje estético. 
Proyecto educativo y dinámica del mestizaje:

ideales de progreso y eugenesia culturalista

El proyecto educativo delineado en Nuestra comunidad indígena comprende dos tareas vinculadas entre sí. Como primera medida, luego del descenso etnográfico al mundo indígena, el ensayo le asigna a los intelectuales (y en particular a los educadores) la misión de "elevar" el nivel cultural y moral de los indígenas al de las poblaciones costeñas, que se consideran ya amestizadas -desde una acepción culturalista del término-, ya que allí predominan sujetos mestizos modernos, que detentan una visión occidental del mundo. La segunda misión, más específica, consiste en brindar una educación técnica que racionalice las prácticas laborales, y que promueva el uso racional de los recursos productivos, con el fin de estimular la prosperidad material de las comunidades (que a su vez, como vimos, es un proceso que sostiene también el avance del mestizaje occidentalizante).

Este proyecto hace sistema con la idea de mera educación moral, promovida en Argentina desde la Generación del 37 hasta entrado el siglo XX. Las masas son predominantemente irracionales, de allí que no convenga difundir entre ellas la educación intelectual (que será inútil, e incluso peligrosa, porque exacerba funciones para las cuales los sujetos populares no están preparados). En este sentido, para los indios Castro Pozo parece adoptar la perspectiva que José Ingenieros y la élite intelectual de la revista Archivos de psiquiatría y criminología (1902-1913) adoptan para los individuos peligrosos -junto con otros sujetos considerados al margen de la "normalidad"- y para los sectores populares en general: al ser pura fuerza, éstos necesitan una educación fundada en el estímulo de sus pasiones, pero re-conducidas hacia ideales positivos. Para la concreción de ese proceso educativo, el ensayo apela a la construcción de un "ideal". La fuerza impulsora del ideal resulta un elemento común a los demás indigenismos abordados en este trabajo. Castro Pozo se pregunta:

¿En qué ideal debería beber la esperanza de un nuevo resurgimiento? Sólo los pueblos que, al ser conquistados por otros han traspasado los umbrales del teocratismo y se han formado el concepto de un ideal más humano, íntimamente relacionado con su propia naturaleza, han podido salvar los escollos de la degeneración y reconstruirse a sí mismos volviendo a readquirir la preponderancia que ejercieron (Castro Pozo [1924] 1979: 154-155; negritas en el original). 
Si bien, el autor postula la necesidad de que ese ideal esté cargado de fines "humanos", para terminar con la "degeneración" y "reconstruir" al indígena de tal modo que alcance un estatus de humanidad moderna, identificamos en Nuestra comunidad indígena, una concepción de "ideal" que difiere de la enunciación espiritualista ligada a la tradición del Ariel de Rodó. Castro Pozo parece inclinarse por un concepto de "ideal" de base positivista, más afín al de El hombre mediocre (1913) de José Ingenieros, marcado por el carácter práctico y pragmático de sus efectos civilizatorios. ${ }^{71}$ Veamos. En su ensayo advierte:

\begin{abstract}
¿Sería posible, sin constituir a estos pueblos, por su educación, un ideal superior [...] enseñarles que aprovechen mejor sus tierras, el pasto de sus punas y seleccionen sus productos para la venta? ¿obtendrían alguna utilidad de dichos conocimientos en el caso de que los aprendieran y practicaran?/ La necesidad es el más provechoso y benéfico aguijón que ha impulsado a los pueblos al descubrimiento y conquista de los medios para satisfacerse. La historia de toda civilización se ha constituido, enmendado y ratificado merced a esta única y suprema causal de su existencia; por lo que, si nuestras comunidades buenamente han satisfecho y satisfacen las suyas que sólo se radican a las de su vida vegetativa y comunitaria; para impulsarlas a la prosecución de un mayor desenvolvimiento económico, ético y social, habría que crear, fomentar en su espiritu necesidades de esta naturaleza, elevarlas en una palabra, a nuestro nivel moral y cultural y capacitarlas para que puedan llevar a cabo el ideal de que se les ha hecho poseedoras (Castro Pozo [1924] 1979: 310; cursivas y negritas en el original).
\end{abstract}

La finalidad educativa de inserción de una racionalidad económica y social moderna, de elevación ética, moral y cultural, se conjuga nuevamente con una consideración del efecto civilizatorio de la promoción de necesidades más complejas -ligadas a una sociedad de mercado- que las existentes en la vida comunitaria. El trabajo y el "amor al progreso" (Castro Pozo [1924] 1979: 56) son los ideales que promueve el ensayo.

El destino del ascenso promovido por la educación "a nuestro nivel moral y cultural" da cuenta de la representación imaginaria de un proceso de mestizaje cultural que operaría una homogeneización "desde arriba", para integrar a los sectores populares tradicionales indígenas. La efectividad de ese proceso es confirmado por el autor cuando señala que, si bien "parece que estuvieran signados a degenerar y desaparecer en la esclavitud del pongaje y yanaconismo [...], estos defectos desaparecen bien pronto con una educación esmerada, el cambio del trato que reciben y el conocimiento o prueba de que son tan valiosos elementos como los otros" (Castro Pozo [1924] 1979: 67).

Nos interesa remarcar, en este punto, el rol normativizador y modernizador asignado al intelectual, en la medida en que la educación y el higienismo van de la mano, para eliminar

\footnotetext{
${ }^{71}$ Sobre el proyecto educativo de Archivos... y la conjunción del discurso positivista de Ingenieros con elementos idealistas en El hombre mediocre, ver respectivamente Mailhe (2019a) y Mailhe (2013a).
} 
los rasgos que la psicología de las multitudes atribuye a las capacidades intelectivas de los indígenas. Así, si los indígenas

... por suerte se encuentran [con un maestro] que se preocupa por su adelanto y mejoramiento y les exige que se aseen todos los días, lustren el calzado y asistan peinados, hay necesidad de sostener una lucha terrible para a fin de que se habitúen a estos actos; los cuales desaparecen al instante en el período de vacaciones (Castro Pozo [1924] 1979: 67; cursivas nuestras).

Otro elemento distintivo, en la compleja matriz discursiva de Nuestra comunidad indígena, es el abordaje del mestizaje desde una dimensión estética que propone el baile como sinécdoque de una mixtura ejemplar. En torno a este razonamiento, Castro Pozo se refiere a la obra $E l$ baile (1899) del francés Raoul Charbonnel, para mostrar el baile -y citando a Nietzche, la música $-^{72}$ como expresión de un mestizaje armónico, libre de toda consideración sobre el poder y la violencia:

En el baile, por ejemplo, a cuya embriogenia concurrieron las predisposiciones estético-rítmicas de conquistadores y conquistados, como se ha visto en el decurso de los acápites anteriores, se puede estudiar el amalgamamiento de dichos factores, sus elementos constitutivos, armónicos en la motivación estética que objetivan e idealizan. Y así se ve, en concreto, en los bailes de las poblaciones mestizas e indígenas de la costa [...] en algunos se han refundido sus elementos constitutivos a tal punto que es difícil distinguir uno de otro, en los menos han armonizado conforme a la afectividad de sus motivos y en íntima relación con los sentimientos que traducen. Y si a aquellos elementos se agregan los que la raza negra aportó en sus usos y costumbres que continuó practicando, pues que ésta también sirvió de base a un nuevo mestizaje generado entre aquella y la de sus amos... (Castro Pozo [1924] 1979: 243; cursivas nuestras).

En el baile, los elementos estéticos indígenas y los europeos aparecen "amalgamados" de tal manera que, por momentos, no es posible identificar el aporte de cada etnia, a la que además se añaden elementos de la raza negra. En las poblaciones mestizas, el baile genera un nuevo colectivo social. Esta concepción simétrica y armónica del mestizaje convive con otras representaciones donde, en la dinámica de mezcla, predomina lo europeo, mientras que los aportes de las alteridades se apagan:

\footnotetext{
${ }^{72}$ El filósofo Nietzche, dice Castro Pozo, manifiesta que "entre todas las artes que crecen en el suelo de una civilización determinada, la música es la última planta que aparece” (Castro Pozo [1924] 1979: 223).
} 
[En este] fenómeno de hibridación social, en que algunos valores étnicos perdieron su peculiaridad; la población mestiza constituyó el origen de multitud de prácticas y costumbres como el baile, que propiamente debía representar las diversas etapas de su civilización porque aquella era imposible adoptara como suyas las de sus antepasados o integralmente alguna de aquestas: signada como nación con la sangre indígena de su rama materna, vino a menos en el concepto del orgulloso conquistador quien, desde luego, la relegó a segundo término; moldeado su corazón en el hogar silencioso, al calor de los recuerdos de la pasada grandeza, la felicidad o el señoría perdidos; aunque bulleran en sus venas los ardores de la conquista y la sed de aventuras de sus padres, fatalmente llegó a ser un producto social intermediario en cuya urdimbre psíquica no llegaron a concretarse las tendencias de las razas que lo generaron, sin menoscabo de su propia valoración, sino predominando las de la conquistadora. El medio social en que estaba relegada la predestinó a ser la base de la nueva nacionalidad (Castro Pozo [1924] 1979: 242).

En ese baile miscigenador, lo indígena aporta a la definición de la nación, pero el europeo la "relega a segundo término" para postularse como "base de la nueva nacionalidad". Asumiendo un punto de vista hegemónico, el ensayo, lo indígena queda subsumido como un elemento necesario para la conformación de nuevas poblaciones mestizas "de mayor cultura", en base a la tradición europea (Castro Pozo [1924] 1979: 137), ubicadas en un estadío civilizatorio evolucionado en sentido de una modernización occidental. Castro Pozo ve en ese mestizaje un verdadero horizonte de redención cultural. El peso telúrico de la costa, como propiciador del mestizaje, vuelve a reponer un tema ligado a las disputas regionalistas al interior de la elite.

Por último, en consonancia con los proyectos de constitución de una mano de obra y una industria indígenas, Castro Pozo pondera la conformación de un mercado de trabajo y comercio interregional e internacional que presupone la producción agropecuaria y agroindustrial, y el avance del mestizaje y de la cultura occidental. En sus palabras, "la inter-regionalización y cosmopolitismo [...] se va constituyendo a medida que los pueblos se ponen en relación por la apertura de caminos e inmigración de las masas trabajadoras hacia los centros industriales" (Castro Pozo [1924] 1979: 243). Aquí se unen los principales elementos de la propuesta de Nuestra comunidad indígena, donde el proyecto de modernización económica hace sistema con el mestizaje cultural folclórico-educativo que propone el ensayo. 
En Nuestra comunidad indígena, el choque entre la lógica productiva de las comunidades y la lógica productiva de mercado que requiere un proyecto de economía mixta resulta un síntoma de las contradicciones que atraviesan todo el ensayo. Allí se propone modernizar el régimen de trabajo para orientarlo hacia metas de producción y productividad, con la precondición de depurar el modo de producción indígena y extirpar los elementos de su cosmovisión que resultan incompatibles con una orientación de la producción hacia el mercado agro-exportador, para competir con el latifundio y con diversas industrias. Su modernización implica el borramiento o la disolución de áreas de la subjetividad indígena que, preservada ahora en el diario etnográfico, será arrasada por la modernización burguesa. Del mismo modo -como vimos- todo el ensayo se sitúa en un cruce inestable entre lo ideológico y lo epistemológico en la representación de lo indígena que satura de contradicciones el discurso de Castro Pozo, y que presenta afinidades con las tensiones existentes en el indigenismo promovido desde el Estado.

\section{Los Siete ensayos de interpretación de la realidad peruana de Mariátegui como apuesta social a fines de los años veinte}

Para 1928 el entramado discursivo del "problema del indio" está plenamente constituido y puede considerarse un discurso hegemónico en el campo intelectual peruano. La crítica a la dominación oligárquica de la República Aristocrática, el reformismo oligárquico, los 
proyectos de modernización social, económica y cultural, las demandas regionalistas, las disputas políticas entre el gobierno y la oposición, la acción del Estado, las discusiones al interior de la "nueva generación", la renovación estética de las vanguardias y la consolidación de las ciencias sociales emergentes - sobre todo la antropología- se enuncian, en mayor o en menor medida, bajo la forma de una defensa del "indio".

Mariátegui sigue muy de cerca este tópico: no sólo ha leído lo que tenían para decir sobre el tema los intelectuales de la oligarquía tradicional señorial, la reformista y la modernizadora de Leguía, sino que también está al tanto de los ensayos indigenistas de la nueva generación. Sometido a las presiones y límites del discurso indigenista, pero posicionado como un lector agudo del discurso social por práctica intelectual, el autor venía interviniendo en el debate desde 1925, en revistas como Mundial; además, en gran medida, organiza ese debate desde la dirección de Amauta, la revista desde la cual invita a la nueva generación peruana a tomar "definiciones ideológicas" (Beigel: 2006). Desde ese mismo año, publica ensayos de intelectuales como Valcárcel. El primero que edita es El nuevo absoluto (1926) de Mariano Ibérico, libro aparecido en su flamante editorial Minerva y que reflexiona sobre la emergencia de una nueva voluntad religiosa que, para el autor, es un dato clave de la época y que se evidencia en la nueva metafísica y en el socialismo. Desde estos dispositivos promueve el indigenismo en todas sus modulaciones (antropológica, estética, sociológica y política).

La biografía de Mariátegui ha sido largamente estudiada en los trabajos recientes de Beigel (2003, 2006), Lagos (2010) y Tarcus (2001), entre otros. Para esta investigación nos interesan algunos datos de su trayectoria: Mariátegui nace en el marco de una familia humilde de Moquegua, a 1100 kilómetros de Lima, ciudad a la que migra en hacia 1899. Se forma de manera autodidacta en el ámbito del periodismo de ideas, al que ingresa como trabajador gráfico. A comienzos de los años veinte ya es un exponente de la crítica a la dominación oligárquica, desde posiciones cercanas al reformismo universitario en su expresión más radical. Entre 1921 y 1923, el gobierno de Leguía le financia un viaje a Europa, en lo que se considera un modo "amable" de deportación. En Europa se acerca a las prácticas y producciones culturales de las vanguardias políticas y estéticas, siendo el acercamiento al marxismo historicista italiano del PSI/PCI un punto de clivaje para su discurso y el ejercicio de prácticas editorialista revisteriles y de libros. A su retorno en 1924, le es amputada una pierna por una vieja lesión de la niñez, que lo deja en silla de ruedas. A principios de 1928, año de publicación de Siete ensayos... rompe con el APRA y funda el Partido Socialista Peruano, y en 1929 la CGT de Perú. En el último lustro de la década del veinte su salud fue 
empeorando paulatinamente -agravada por las persecuciones y detenciones por parte del gobierno de Leguía, fundadas en base a un supuesto "complot comunista"- hasta desencadenar su muerte en 1930.

Los Siete ensayos de interpretación de la realidad peruana se editan en noviembre de 1928. Para ese año, el giro autoritario y excluyente en términos sociales del gobierno de Leguía se ha endurecido, pasando del exilio como política represiva, a la cárcel y la represión de opositores políticos, como en el caso de Mariátegui. El leguiísmo ha vuelto a vincularse con los sectores terratenientes -viejos aliados de la oligarquía tradicional señorial que había venido a combatir-; ha disuelto buena parte de los organismos y políticas orientadas a la población indígena, aunque mantiene su indigenismo discursivo. Creemos que la publicación de los Siete ensayos... persigue la formulación de medidas que el autor considera posibles para la coyuntura política existente al momento de su edición, en la que la crisis de la hegemonía oligárquica se encuentra en una fase de fuerte conflictividad.

¿Cuál es la "apuesta" que, en términos de Angenot (2010), comportan los Siete ensayos... como intervención discursiva, en el campo intelectual peruano, a fines de 1928 ? ¿Y qué dimensiones puede iluminar, en ese sentido, el análisis de las representaciones de la alteridad social indígena...?

Desde nuestro punto de vista, las representaciones de lo indígena se conectan con cuatro núcleos temáticos que articulan el ensayo: la realización de una reforma agraria, la constitución de una dirigencia indigenista que la ponga en marcha, el emprendimiento de las tareas ideológicas que permitan conformar esa dirigencia y efectivizar la reforma (el ensayo es concebido en ese sentido, como afirma Liliana Weinberg -2004-, como catalizador de la acción), y por último $-\mathrm{y}$ en relación con el punto anterior-, la puesta en marcha de una política cultural para la configuración de un imaginario nacional indigenista, que promueva los valores y las acciones que disparen el desarrollo de Perú en clave indigenista.

Creemos, en ese sentido, que Mariátegui trata de interpelar en términos "arielistas" a los intelectuales emergentes de la Reforma Universitaria, algunos de ellos ex funcionarios del Estado, para señalar la necesidad de acción en base a un diagnóstico marxista situado en las coordenadas nacionales en las que lo indígena ocupa un lugar central (Lagos: 2010). Sin embargo, Mariátegui no le habla al indígena. Diseña una política para el indígena (incluyente, virtuosa, reparatoria, que lo inviste de recursos e imagina un proyecto de vida y un posible futuro emancipatorio), y la hace circular en el formato intelectual por antonomasia: el ensayo, 
lo cual resulta un indicio de que el lector imaginado para los Siete ensayos... es un lector intelectual o al menos conocedor de la tradición que piensa la modernización latinoamericana. En ese sentido, la centralidad que toman el espíritu, la religión, la cultura, los ideales -términos centrales del discurso filiado al Ariel de José E. Rodó- será pensada como un poderoso dinamizador de la acción. En ese sentido, apelando a la lectura de Sazbón (2002), podemos pensar que Mariátegui intenta "poner el idealismo de cabeza" o, en otras palabras, orientar el espiritualismo arielista hacia fines sociales, materiales.

En su propuesta, al igual que sucedía con los otros autores considerados en esta tesis (y con los indigenistas previos y posteriores en general), la dirigencia intelectual ocupa un lugar central, lo cual resulta un dato clave en nuestra interpretación del ensayo: son éstos los principales destinatarios imaginados por Mariátegui (y no los sujetos indígenas, o los sectores trabajadores urbanos).

Creemos que la obra puede ser pensada, en este sentido, como una herramienta de movilización ideológica de los intelectuales, hacia un horizonte de radicalización.

\section{El ensayo}

En la "Advertencia" que abre el ensayo, Mariátegui dice que éste fue producido a partir de los escritos publicados en Mundial y Amauta. Para su autor, el libro no tiene un carácter orgánico. Esta característica supone un correlato en el plano representacional. Efectivamente, los Siete ensayos... presenta, compositivamente, cierta semejanza con la técnica vanguardista del collage. Mariátegui inserta representaciones imaginarias de los indígenas a partir de las representaciones implícitas en otros discursos -arqueológicos, antropológicos, sociales, económicos, históricos, literarios y de la crítica literaria, entre otros- que recorren el pasado y el presente, movilizando la imaginación de un futuro para Perú. Con ellos, compone el tópico central del ensayo: el lugar de los indígenas en la modernización social y en la construcción de una nueva nacionalidad (esto es, en la reconfiguración de Perú). La apelación a la figura moderna del collage supone una aproximación a la epistemología implícita en las vanguardias estéticas, y conduce a enriquecer las representaciones, así como también a ampliar la diversidad de temas que abre; sin embargo, también genera un efecto centrífugo en el análisis, que deriva en un espectro amplísimo de cuestiones relacionadas con el diagnóstico de la realidad peruana. 
Con ese gesto vanguardista que evocamos, convive la voluntad de desplegar una argumentación apegada a las reglas del discurso científico. Como afirma Lagos (2010), entre muchos otros críticos, Siete ensayos... es considerado un texto pionero en el pasaje desde la escritura intelectual de entresiglos -más impresionista-, hacia una discursividad científica. Y si bien su autor dice que intenta colocarse "lo más lejos posible de la técnica profesoral" (Mariátegui [1928] 2011: 6), despliega un discurso con elementos pedagógicos, mostrándose como un gran conocedor y como un ávido investigador. Además, dispone ante el lector de todo el catálogo de una vasta biblioteca de temas actuales que se intersectan con el discurso indigenista, e invita a recorrerla, con él como guía o referencista. En ese sentido, las figuras del viaje arqueológico de Valcárcel, del etnográfico de Castro Pozo y aun el paseo al estilo del flâneur de Uriel García, dan paso a la figuración del estudio del científico.

Es probable que esto también incida en que, a comparación de los otros ensayos abordados, en Siete ensayos... haya pocas representaciones del indígena y del intelectual -del pasado, el presente y el futuro- aunque éstas adquieren una gran visibilidad y centralidad en el ensayo. No obstante, cada inserción de una representación, imagen o figura, es rodeada de un dispositivo textual interpretativo que -acorde a las reglas científicas de las emergentes ciencias sociales, como la sociología y la economía- sutura los puntos de fuga que abren las representaciones, y que en los ensayos anteriormente trabajados quedaban menos controladas argumental e ideológicamente. Por ende, analizar representaciones en los Siete ensayos... exige realizar un arduo trabajo de deconstrucción de esa discursividad científica, para llegar a las composiciones imaginarias del "indio".

Esa intención enunciativa "científica" se articula con un punto de vista que el propio ensayo identifica como parte de la ciencia moderna, al que refiere en múltiples ocasiones, y al que llama "crítica socialista" (Mariátegui [1928] 2011: 25) y "materialismo histórico", que filia a la tradición de pensamiento fundada por Marx y Engels, cuyas respectivas obras $E l$ capital y Socialismo utópico y socialismo científico (sic.) cita en el libro. Así Mariátegui se lanza explícitamente a la disputa ideológica del discurso de las ciencias sociales.

El autor combina esos registros en su discurso, al tiempo que se apropia y usa creativamente el acervo de los ensayos indigenistas y de otros textos contemporáneos (locales, latinoamericanos y europeos) para construir un punto de vista novedoso y arriesgado sobre la modernización peruana y sobre el lugar que en ella deben tener los indígenas.

A la vez, su propuesta está muy marcada por la recepción de discursos innovadores, emergentes de la coyuntura de los agitados años veinte, que venían siendo procesados en los ensayos y publicaciones de la "juventud" arielista peruana y latinoamericana en general, y 
que luego son retomados en los debates e intercambios del reformismo universitario del que emerge la "nueva generación peruana". Los hechos que marcan este imaginario son la Revolución Mexicana, señalando la potencia del colectivo indígena movilizado (y probablemente tomando de allí la necesidad de una reforma agraria, aunque con características propias), la Reforma Universitaria que había dejado como saldo una experiencia de reforma efectiva de los ámbitos académicos (y una nueva intelectualidad que se debatía entre el traspaso de los marcos ideológicos del reformismo arielista y que, disconforme con las políticas oligárquicas, debatía los modos y la metas de la acción intelectual), la Revolución Rusa como imaginario modernizador (que habilita la conexión con el pasaje a un orden socialista -o la constitución de áreas económicas y culturales regidas por ese tipo de ordenamiento- sin pasar por el capitalismo -que se aborda al tematizar la comunidad y la "nueva civilización" rusas-), y la emergencia de las vanguardias estéticas (que vienen a poner en cuestión la representación estética -en particular, la mímesis realista, clave en la estética occidental- $\mathrm{y}$, en general, a producir reflexiones en torno a las prácticas representacionales y a su lugar en la construcción de los imaginarios nacionales).

Como en los demás autores abordados, el punto de partida necesario de todo el ensayo es la resemantización de lo indígena, que permite abrir el horizonte de posibilidades imaginado por Mariátegui. Veamos. 
Una vez pasada la "Advertencia", el ensayo se abre con una representación de lo indígena articulada con el imaginario de lo inca:

Hasta la Conquista se desenvolvió en Perú una economía que brotaba espontánea y libremente del suelo y la gente peruanos. En el Imperio de los Incas, agrupación de comunas agrícolas y sedentarias, lo más interesante era la economía. Todos los testimonios históricos coinciden en la aserción de que el pueblo inkaico -laborioso, disciplinado, panteísta y sencillo- vivía con bienestar material. Las subsistencias abundaban; la población crecía. El imperio ignoró radicalmente el problema de Malthus. La organización colectivista, regida por los Inkas, había enervado en los indios el impulso individual; pero había desarrollado extraordinariamente en ellos, en provecho de este régimen económico, el hábito de una humilde y religiosa obediencia a su deber social. Los Inkas sacaban toda la utilidad social posible de esta virtud de su pueblo, valorizaban el vasto territorio del Imperio construyendo caminos, canales, etc., lo extendían sometiendo a su autoridad tribus vecinas. El trabajo colectivo, el esfuerzo común, se empleaban fructuosamente en fines sociales (Maríátegui [1928] 2011: 7).

Mariátegui le propone al lectorado ingresar a la realidad peruana a través de la evocación imaginaria del Imperio Inca. Un Imperio rico y vasto, urbanísticamente desarrollado, atravesado por obras viales y de irrigación, en el que la comida abunda y la población aumenta sostenidamente. El imperio rige sobre una serie de comunidades que cultivan y crían ganado, cuyos habitantes son sencillos y laboriosos. Creen en la espiritualidad de la naturaleza, la tierra, el universo. Los indios obedecen religiosa y disciplinadamente los deberes sociales que la realeza inca señala como objetivos para el virtuoso esfuerzo común. Entre esos objetivos, Mariátegui destaca - esto será una constante en el ensayo- las prácticas productivas y su utilidad para los fines sociales, y sobre todo para los económicos. La práctica militar es considerada también como un fin social, que en el caso de los Incas le da al Imperio una importante condición expansiva.

Las características de lo inca se articulan así en torno a un pasado de grandeza, pleno de riqueza, una dirigencia legítima y eficaz, un pueblo simple, trabajador, disciplinado y creyente en esa dirigencia y en los fines sociales que determina. Un pueblo que vive con bienestar material y que adora religiosamente esa geografía productiva que se presenta como el mundo del indígena del pasado. En la representación de Mariátegui, esos elementos se articulan con una significación de armonía social entre dirigentes, dirigidos, naturaleza y bienestar social. 
La representación del pasado incaico que hace Mariátegui se apoya en los intensos debates (disparados en gran medida por el descubrimiento arqueológico de Machu Picchu entre 1902 y 1910, y publicitado hasta fines de la década del veinte por la arqueología nacional) que discuten el carácter comunista o no del régimen incaico. El mismo año de edición de los Siete ensayos... Louis Baudin edita en Francia El imperio socialista de los Inkas (1928), y autores locales como César Ugarte abordan este tema de amplia circulación. En Bosquejo de la historia económica del Perú (1927) Ugarte cita a Max Ulhe y Heinrich Cunow -marxista socialdemocrata alemán- y a Bautista Saavedra en su libro El Ayllu (1919), autor boliviano que dialoga y discute con Alcides Arguedas y Franz Tamayo sobre esta cuestión, y Ugarte y el propio Mariátegui recuperan también al Inca Garcilaso de la Vega para acompañar la descripción de otros tópicos sobre la organización social incaica. Nos parece importante remarcar que, en ese campo discursivo en disputa, Mariátegui toma partido en favor de la tesis de que la sociedad inca era comunista, implicando un orden elevado en términos de desarrollo civilizatorio y con una fuerte valoración del crecimiento económico, lo cual -como veremos- para Mariátegui puede y debe ser el punto de partida de un nuevo proyecto para los indígenas peruanos y americanos.

Los elementos espirituales de la dominación inca encastran armoniosamente con la descripción de las características espirituales de los indígenas que conforman el "pueblo" del Imperio. Este es un punto clave, también sostenido sobre una urdimbre de amplias discusiones. El análisis de la religión, la espiritualidad, las creencias y el lugar que éstas ocupan en la modernización social de la humanidad a través de la historia, en particular la de Perú, es abordado en todo el ensayo. Veamos la descripción detallada que hace en el siguiente párrafo, que vale la pena citar extensamente:

La religión del quechua era un código moral antes que una concepción metafísica, hecho que nos aproxima a la China mucho más que a la India. El Estado y la Iglesia se identificaban absolutamente; la religión y la política reconocían los mismos principios y la misma autoridad. Lo religioso se resolvía en los social. Desde este punto de vista, es evidente entre la religión del Inkario y las de Oriente la misma oposición que James George Frazer consta entre estas y la civilización greco-romana. "La sociedad, en Grecia y en Roma -escribe Frazer-se dudaba sobre la concepción de la subordinación del individuo a la sociedad, del ciudadano al Estado; colocaba la seguridad de la república como fin dominante de conducta, por encima de la seguridad del individuo, sea en este mundo, sea en el mundo futuro. Los ciudadanos educados desde la infancia en este ideal altruista, consagraban su vida al servicio del Estado y estaban prontos a sacrificarla por el bien público. Retrocediendo ante el sacrificio supremo, sabían muy bien que obraban bajamente prefiriendo su existencia personal a los intereses nacionales. La propagación de las religiones orientales cambió todo esto [...]/ Identificada con 
el régimen social y político, la religión inkaica no pudo sobrevivir al Estado inkaico. Tenía fines temporales más que fines espirituales. Se preocupaba del reino de la tierra antes que del reino del cielo. Constituía una disciplina social más que una disciplina individual. El mismo golpe hirió de muerte la teocracia y la teogonía. Lo que tenía que subsistir de esta religión, en el alma indígena, había de ser no una concepción metafísica, sino los ritos agrarios, las prácticas mágicas y el sentimiento panteísta./ De todas las versiones que tenemos sobre los mitos y ceremonias inkaicas, se desprende que la religión quechua era en el Imperio mucho más que la religión del Estado [...] La Iglesia era el Estado mismo. El culto estaba subordinado a los intereses sociales y políticos del Imperio (Mariátegui [1928] 2011: 121-122).

La visión armónica de la sociedad incaica es articulada por el cruce entre religión, dominación, política, fines sociales y moral popular. El Estado, la Iglesia y el deber social de los habitantes para con el crecimiento inca aparecen amalgamados. Mariátegui usa fragmentos de The Golden Bough (1890) de James George Frazer para afirmar que la religión era el elemento que lograba la concreción de esa sociedad armoniosa y económicamente próspera que describimos en páginas anteriores. Para Mariátegui, la autoridad inca, a la vez religiosa y política, orienta sus premisas en favor de la concreción de fines sociales y políticos que aumentan el bien común y que promueven un "código moral” religioso en los habitantes, donde prestar servicios para el colectivo social (que, como la seguridad común, está por sobre cualquier interés individual). En este sentido, indirectamente sobre esa dirigencia, tal como se perfila en Siete ensayos..., creemos que se recorta un modelo normativo de dirigencia intelectual.

Pero además, la apelación a la religión autoriza la aproximación de la sociedad incaica a otras grandes "civilizaciones" antiguas como China, y con la cita de autoridad de Frazer, a la "civilización greco-romana" (Mariátegui [1928] 2011: 121), frente a la cual señala que la similitud central es el vínculo entre Estado, religión y ciudadano. ${ }^{73}$ Esto refuerza insistentemente la operación legitimadora del pasado inca que, ubicado ahora en las cercanías del período clásico, resulta más asimilable para las elites modernistas y para gran parte del lectorado de la tradición del ensayo latinoamericano, que considera ese modelo como un horizonte privilegiado de "civilización" y de "alta cultura" estética.

Con respecto a esta condición "civilizatoria", es oportuno mencionar que Mariátegui no quiere romper con una mirada evolucionista ligada al concepto de "civilización", que considera la existencia de una escala jerárquica en la que Occidente es modelo pasado y

\footnotetext{
73 "El pueblo inkaico ignoró toda separación entre la religión y la política, toda diferencia entre Estado e Iglesia. Todas sus instituciones, como todas sus creencias, coincidían estrictamente con su economía de pueblo agrícola y con su espíritu de pueblo sedentario. La teocracia descansaba en lo ordinario y lo empírico; no en la virtud taumatúrgica de un profeta ni de su verbo. La religión era el Estado" (Mariátegui [1928] 2011: 124).
} 
presente, y en la que el Perú del pasado, pero también del futuro, tienen un lugar destacado. Esta defensa de la civilización occidental puede observarse cuando valora los pueblos de Oriente que supieron traducir a sus propias lenguas las experiencias modernas de Occidente: “...la experiencia de los pueblos de Oriente, el Japón, Turquía, la misma China, nos han probado cómo una sociedad autóctona, aun después de un largo colapso, puede encontrar por sus propios pasos, y en muy poco tiempo, la vía de la civilización moderna y traducir, a su propia lengua, las lecciones de los pueblos de Occidente" (Mariátegui [1928] 2011: 301). En este sentido, es importante remarcar el valor positivo otorgado por el autor a la civilización occidental como elemento modernizador. El tópico positivista de la civilización se inscribe en la pregunta por el desarrollo, que se analiza en base a la comparación entre el desarrollo del occidente capitalista y las sociedades no occidentales o de las occidentales "atrasadas" (España suele ser puesta como ejemplo paradigmático en este último sentido). El linaje imperial, junto con la consideración de semejanzas estructurales y de proceso con la experiencia de la Rusia soviética -considerada, a diferencia de las recepciones liberales de la misma, como el punto más álgido de la evolución civilizatoria-, serán utilizados para hacer emerger nuevos elementos imaginarios sobre la modernización peruana. ${ }^{74}$ Indagaremos más adelante qué efectos tiene la incorporación de este discurso sobre la modernización rusa en el discurso que piensa los destinos de Perú y del continente americano.

El autor prolonga y profundiza el análisis de la tríada Estado-religión-indígena:

En lo que concierne al problema indígena, la subordinación al problema de la tierra resulta más absoluta aún por razones especiales. La raza indígena es una raza de agricultores. El pueblo inkaico era un pueblo de campesinos, dedicados ordinariamente a la agricultura y el pastoreo. Las industrias, las artes, tenían un carácter doméstico. En el Perú de los Inkas era más cierto que en pueblo alguno el principio de que la "vida viene de la tierra". Los trabajos públicos, las obras colectivas, más admirables del Tawantinsuyo, tuvieron un objeto militar, religioso o agrícola. Los canales de irrigación de la sierra y de la costa, los andenes y terrazas de cultivo de los Andes, quedan como los mejores testimonios del grado de organización económica alcanzado por el Perú inkaico. Su civilización se caracterizaba, en todos sus rasgos dominantes, como una civilización agraria. La tierra -escribe Valcárcel estudiando la vida económica de Tawantinsuyo- en la tradición regnícola, es la madre común: de sus entrañas no solo salen los frutos alimenticios, sino el hombre mismo. La tierra depara todos los bienes. El culto de la Mama Pacha es par de la heliolatría; y como el sol no es de nadie en particular, tampoco el planeta lo es. Hermanados los dos conceptos en la ideología aborígen, nació el agrarismo, que es propiedad comunitaria de los campos y religión universal del astro del día./

\footnotetext{
${ }^{74}$ Los sentidos contrarios de la recepción de la Revolución Rusa en los indigenistas, puntualmente la valoración negativa que realiza Valcárcel desde el diario El sol a fines de la década de 1910, y la positiva realizada por Mariátegui, es mencionada en Mailhe (2020), y fue también comprobada en el análisis hemerográfico realizado por el autor en Cusco sobre el diario El Sol.
} 
$\mathrm{Al}$ comunismo inkaico -que no puede ser negado ni disminuido por haberse desenvuelto bajo el régimen autocrático de los Inkas- se le designa por esto como comunismo agrario. Los caracteres fundamentales de la economía inkaica -según Cesar Ugarte, que define en general los rasgos de nuestro proceso con suma ponderación- eran los siguientes: "propiedad colectiva de la tierra cultivable por el "ayllu" o conjunto de familias emparentadas, aunque dividida en lotes individuales intransferibles; propiedad colectiva de las aguas, tierras de pasto y bosques por la "marca" o tribu, o sea la federación de ayllus establecidos alrededor de una misma aldea: cooperación común en el trabajo: apropiación individual de las cosechas y frutos [Después de la conquista y la colonia] los nativos se redujeron a una dispersa y anárquica masa de un millón de hombres, caídos en la servidumbre y el fellahismo (Mariátegui [1928] 2011: 36-37)

Ampliando la representación de la sociedad indígena incaica, la define como una "civilización agraria" conformada por la "raza indígena". El uso de "raza" parece alimentar aquí el halo civilizatorio, más que señalar una coordenada epistemológica. En el Imperio, afirma, el culto a la tierra, al sol y a los productos de la tierra se retroalimenta con las prácticas productivas indígenas, prácticas que a su vez lo engrandecen. Mariátegui confirma un círculo virtuoso, religioso y productivo, entre lo indígena y la tierra, del que se deriva el "alto grado de organización alcanzado por el Perú inkaico". La tierra, como señala al comienzo del párrafo, es un elemento central de esa cosmovisión religiosa que Mariátegui define como "agrarismo", utilizando el término acuñado por Valcárcel en Del ayllu al imperio (1925).

Acto seguido, afirma con Ugarte que la configuración económica del Imperio se define como un "comunismo agrario", cuyos caracteres distintivos se sintetizan en la comunidad incaica, en el ayllu. En la cita de Ugarte, la comunidad es presentada como una agrupación de familias articulada por el parentesco, donde la propiedad del agua y la tierra es de la comunidad; donde el trabajo es cooperativo, y el uso de la propiedad y el consumo de los productos de la tierra es individual e intransferible. Retengamos esta definición de la comunidad, y la centralidad que tiene en la organización económica, ya que será reactivada en el análisis del presente del ensayo.

Nos parece importante destacar la tensión entre lo colectivo y lo individual en materia de propiedad que se desarrolla en la "federación de ayllus" o comunidades que integran la sociedad incaica. Ésta se presenta también en otros discursos indigenistas sin nunca cerrarse del todo. Parece sugerir la apertura de vasos comunicantes con las formas de propiedad privada, probablemente otro elemento tranquilizador para la mirada de un lector burgués. Vimos que Castro Pozo, a quien el autor de Siete ensayos... cita extensamente, establece en ese mismo sentido la posibilidad de traducción de las relaciones capitalistas de propiedad y trabajo, bajo las formas del trabajo cooperativo y del contrato colectivo de trabajo. 
Al final del párrafo, la conexión entre los indígenas incaicos del pasado y los indígenas del presente reintroduce el ideologema de la negatividad indígena del presente, apelando a la terminología spengleriana de La decadencia de Occidente mediada por César Ugarte (recordemos que la cita es de su Bosquejo de la historia económica del Perú, de 1926). De ese modo, repone la idea presente también en Tempestad... de Valcárcel, de que los indígenas, una vez liquidada la sociedad inca por la conquista, "caen" en la escala civilizatoria "en la servidumbre y el fellahismo", reduciéndose a una "masa anárquica" de un millón de hombres.

Sin embargo, el tópico de la inferioridad fellahista de los indígenas -que los ubica fuera de la historia- no persistirá en el ensayo, ya que será neutralizado rápidamente por la afirmación de que esta situación puede ser revertida por medio de la revinculación, productiva y religiosa, del indígena con la tierra.

\section{El indígena del presente:}

la ética comunitaria indígena y el espíritu del socialismo

Mariátegui se lanza a la representación del indígena contemporáneo, al que describe fuera de la escenografía incaica imperial. El espacio del indígena actual es la comunidad indígena del presente: el autor remarca la continuidad de algunos elementos espirituales y prácticas sociales ligadas a ésta, eminentemente vinculados con ese pasado inca, y pasibles de ser revitalizados para revertir la situación de los indígenas, y con ellos, de todo Perú. ${ }^{75}$

Los estudios de Hildebrando Castro Pozo sobre la "comunidad indígena", consignan [en torno al ayllu] datos de extraordinario interés que [...] coinciden absolutamente con la sustancia de las aserciones de Valcárcel en "Tempestad en los Andes" a las cuales, si no estuviesen confirmadas por investigaciones objetivas, se podría suponer excesivamente optimistas y apologéticas. Además, cualquiera puede comprobar la unidad, el estilo, el carácter de la vida indígena. Y sociológicamente la persistencia en la comunidad de los que Sorel llama "elementos espirituales del trabajo", es de un valor capital (Nota al pie n41 en Mariátegui [1928] 2011: 260).

\footnotetext{
${ }^{75}$ Cabe señalar que esa continuidad es argumentada por el autor en base a la consideración histórica de la comunidad como instrumento de resistencia del indígena (Mariátegui [1928] 2011: 62-63), mecanismo de defensa que se reactualiza ante los adversos contextos de la Conquista, la Colonia y la República. No obstante, esa reactualización no se aborda, por lo que la concepción de la comunidad adquiere un leve carácter transhistórico en el análisis de Mariátegui, lo cual contradice otras áreas más controladas del discurso sobre los procesos socio-históricos.
} 
En los indígenas subsisten las prácticas religiosas ligadas a ritos agrarios, las prácticas mágicas, y el sentimiento panteísta, lo que Valcárcel denomina "agrarismo". Este párrafo nos parece clave ya que confirma el vínculo entre pasado y presente en torno a elementos religiosos. La concentración de citas muestra la voluntad de legitimar esa aseveración como un punto firme del ensayo. La advertencia sobre el discurso de Valcárcel aparece como un síntoma del paulatino abandono -nunca logrado del todo- del discurso del intelectual cusqueño, que sólo será retomado en extenso en una nota al pie, más allá de algunas referencias. En efecto, el acercamiento al discurso de Valcárcel, que hasta aquí es notable, se va cerrando posiblemente para tomar distancia respecto de la idea de "resurgimiento" incaico. En la representación del indígena, Mariátegui introduce nuevas referencias que tienen un peso notable en el ensayo, que se llena de citas de Castro Pozo sobre la comunidad indígena, y que incluso incorpora a autores centrales como Sorel.

Como se puede observar al final del párrafo arriba citado, el concepto "elementos espirituales del trabajo", explícitamente tomado del autor de Reflexiones sobre la violencia (1908), conecta con uno de los tópicos más novedosos que los Siete ensayos... despliegan en lo que a la representación de la alteridad indígena respecta: la presencia, entre los indígenas del presente, de lo que llamaremos una ética religiosa del trabajo, que les otorga cualidades excepcionales como trabajadores, y que prolonga, en las comunidades, la armonía social de antaño, en base a la persistencia de "hábitos de cooperación y solidaridad" que son la materialización de un "espíritu comunista". Veamos:

En las aldeas indígenas donde se agrupan familias entre las cuales se han extinguido los vínculos del patrimonio y del trabajo comunitarios, subsisten aún, robustos y tenaces, hábitos de cooperación y solidaridad que son la expresión empírica de un espíritu comunista. La comunidad corresponde a este espíritu. Es su órgano (Mariátegui [1928] 2011: 59).

La terminología espiritualista se vuelve predominante en estas áreas del ensayo. Para Mariátegui, históricamente, todo modo de producción exitoso ha estado vinculado con una dimensión espiritual. Por ello, la presencia de una ética productiva indígena abre paso a la consideración de la posibilidad del desarrollo peruano, al menos en el ámbito serrano rural, con la precondición de la expropiación de los latifundios. 
Las discusiones sobre el lugar de los elementos espirituales en los diagnósticos para la modernización nacional y continental forman parte de un tópico recurrente en la tradición latinoamericana que persigue estos objetivos, al menos desde entresiglos. Ensayos de enorme impacto masivo como el Ariel de Rodó (1900) o El hombre mediocre de Ingenieros (1913) ocupan un lugar importante en esta reflexión.

Cabe recordar además que, en los años veinte, Max Weber analiza desde Alemania sobre la incidencia de los factores espirituales del protestantismo en el desarrollo capitalista anglosajón. Aunque no es posible confirmar la lectura de la obra de Weber por parte de Mariátegui, llama la atención la aproximación significativa, en este punto, entre ambas perspectivas. Esta consideración se da en los Siete ensayos... de la mano del discurso de Waldo Frank en Nuestra América (1919), que es traído a colación precisamente por su análisis del espiritualismo y el idealismo en el desarrollo de Estados Unidos, en base al que se establece una comparación con España, en la que ésta queda desacreditada por la merma de su idealismo desde la modernidad. Como veremos, la valoración de elementos espirituales se expandirá por otras áreas del ensayo, especialmente en torno a la construcción de un imaginario nacional, y para la conformación y/o activación de una dirigencia indigenista que -como los incas- modernice económica y socialmente la nación.

El énfasis dado al espíritu de la comunidad, para el cual -como vimos- trabajar la tierra es un acto cargado de misticismo, conduce a una particular representación imaginaria del indígena, que derriba las caracterizaciones elaboradas en entresiglos por Riva Agüero o por García Calderón:

[Los indígenas se juntan en las] "mingas" o reuniones de todo el "ayllu" para hacer gratuitamente un trabajo en el cerco, acequia o casa de algún comunero, el cual quehacer efectúan al son de arpas y violines, consumiendo algunas arrobas de aguardiente de caña, cajetillas de cigarrillos y mascadas de coca (Mariátegui [1928] 2011: 59-60, insertado textual de Castro Pozo [1924] 1979: 59).

Así, el "indio" es un trabajador feliz y solidario, que además se entrega al trabajo de manera festiva (una característica que no aparece en las descripciones de la sociedad incaica), ya que el trabajo en la "minga" se vivencia como una fiesta colectiva.

Los Siete ensayos... presentan entonces una alteridad indígena del presente de enunciación configurada en torno a los trazos mencionados. El indígena es un trabajador comunitario rural solidario y cooperativo, que encara las tareas con consciencia colectiva y alegría, cargándolas de cierto misticismo; el vínculo con la tradición -o el "espíritu"- 
comunista indígena lo conecta con una dimensión religiosa (en sentido amplio) de las prácticas productivas: trabajar la tierra y hacerla producir es un aspecto central de su cosmovisión. Nos interesa remarcar que esas características llevan a Mariátegui a postular el hallazgo de algo que no encuentra en ninguno de los demás actores de la sociedad peruana, al menos desde la conquista: un sujeto portador de una ética religiosa del trabajo. Éste será un dato promisorio para el proyecto de modernización de la nación que quiere emprender. El ensayo se centra (entre otros objetivos ligados especialmente al orden de la práctica intelectual) en proponer una reforma agraria, bajo la guía de una dirigencia que, como los Incas, le otorgue a la misma un sentido socialmente productivo.

En sintonía con el abordaje de la representación del indígena del presente, la tierra parece ser la llave que remueve las trabas al desarrollo indígena. El acceso a la tierra vendría entonces a revitalizar la comunidad y a poner a rodar el círculo virtuoso entre religiosidad y prácticas productivas.

Mariátegui plantea que el latifundismo no cumple satisfactoriamente con uno de los motivos del capitalismo, esto es, con la intensificación de la producción mediante el desarrollo de técnicas avanzadas de cultivo, ya que el hacendado se preocupa por la rentabilidad antes que por la productividad de las tierras. Y en este sentido, el autor afirma que, a pesar del mayor territorio acaparado por el latifundio, "los rendimientos de los cultivos de las comunidades no son, en su promedio, inferiores a los cultivos de los latifundios" (Mariátegui [1928] 2011: 61). Esta ventaja de la comunidad se da, como vimos, por la existencia en ella de un "sistema de producción que mantiene vivos en el indio los estímulos morales necesarios para su máximo rendimiento como trabajador" (Mariátegui [1928] 2011: $62)$.

Mariátegui crea representaciones imaginarias de esta revinculación, apelando nuevamente a extensos pasajes recortados de la obra de Castro Pozo, en donde se representa a las comunidades indígenas. Esas imágenes parecen evocar el orden social y económico que se instauraría sobre los extintos latifundios con la reforma agraria. En el capítulo anterior vimos el caso de la comunidad de Muquiyauyo, que es presentada también en los Siete ensayos... como el mejor ejemplo de desarrollo de una comunidad. Advierte Mariátegui: 
Castro Pozo, que como jefe de la sección de asuntos indígenas del Ministerio de Fomento acopió bastantes datos sobre la vida de las comunidades, señala y destaca el sugestivo caso de la parcialidad de Muquiyauyo, de la cual dice que presenta los caracteres de las cooperativas de producción, consumo y crédito. "Dueño de una magnífica instalación o planta eléctrica en las orillas del Mantaro, por medio de la cual proporciona luz y fuerza motriz para pequeñas industrias a los distritos [...] se ha transformado en la institución comunal por excelencia; en la que no se ha relajado sus costumbres indígenas, y antes se han aprovechado de ellas para llevar a cabo la obra de la empresa; han sabido disponer del dinero que poseían empleandolo en la adquisición de las grandes maquinarias y ahorrado el valor de la mano de obra que la parcialidad ha ejecutado, lo mismo que si se tratara de un edificio comunal: por "mingas" en las que hasta las mujeres y niños han sido elementos útiles en el acarreo de los materiales de construcción" (Mariátegui [1928] 2011: 61).

Electricidad, fuerza motriz, pequeñas industrias, maquinarias y trabajo comunitario en las mingas -cualidades extraídas de Nuestra comunidad indígena-, en el marco de los Siete ensayos..., quedan vinculados con el imaginario de modernización de la Revolución Rusa: "Rusia, la metrópoli de la naciente civilización socialista, trabaja febrilmente por desarrollar su industria. El sueño de Lenin era la electrificación del país", dice Mariátegui ([1928] 2011: 165). El abordaje de la comunidad refuerza por contigüidad las realidades de ambos países, al equiparar la situación de las comunidades indígenas del presente del ensayo, con las comunidades rusas de los años previos a la Revolución, apelando a los estudios sobre el mir ruso que realiza el autor francés Eugene Schaff en su estudio La question agraire en Russie:

La feudalidad dejó análogamente subsistentes las comunas rurales en Rusia, país con el cual siempre es interesante el paralelo porque a su proceso histórico se aproxima el de estos países agrícolas y semifeudales mucho más que al de los países capitalistas de Occidente (Mariátegui [1928] 2011: 44).

Rusia es vanguardia, industria, desarrollo técnico y tecnológico. La gravitación de ese imaginario modernizador, ligado a la Rusia posrevolucionaria, parece habilitar entonces la posibilidad de un desenlace similar, mediante el logro de objetivos "civilizatorios", tal como se dio en el proceso ruso.

\section{El indígena revolucionario: una nota al pie}

La representación del indígena revolucionario, presente en los Siete ensayos..., está -si retomamos la metáfora que piensa la escritura de Mariátegui bajo la técnica vanguardista del collage - "pegada" a Tempestad en los Andes de Valcárcel, en una nota al pie en el segundo capítulo del ensayo, titulado "El problema del indio". Allí presenta al indígena como un 
sujeto con conciencia de clase, colectivamente organizado, que está realizando ensayos militares para llevar a cabo una revolución indígena bolchevique que, mientras para Valcárcel ([1927] 1970: 134) “busca a su Lenin”, para Mariátegui ([1928] 2011: 26) "lo espera”. Esta divergencia, si bien es sutil, no deja de ser significativa para dejarnos entrever las concepciones normativas que los autores tienen sobre la relación entre los sectores populares y los intelectuales.

Consideramos que esta visión, centrada en la perspectiva revolucionaria, ocupa un lugar menor respecto de la representación del indígena como un trabajador de excelencia. $\mathrm{Su}$ presencia en una nota al pie en los Siete ensayos... deja entrever el lugar menor que el autor le asigna. Además, su aparición es fugaz en términos de extensión, en comparación con las páginas dedicadas al indígena de comunidad, inmerso a su vez en todo un desarrollo argumental sobre la relación entre ideas religiosas y sistemas productivos, a lo largo de toda la historia, abarcando un gran área de interés en el trabajo de Mariátegui.

Esa presencia, literal y figuradamente "en el margen" del ensayo, nos parece sintomática respecto del poco desarrollo que alcanza, en el texto, la representación imaginaria del indígena revolucionario -al silenciarse también la historia de los levantamientos indígenas durante la Colonia, el proceso de Independencia y la República-; en consecuencia, creemos que la apuesta del ensayo está orientada a realizar una reforma agraria en los latifundios de la sierra, y a instalar un modo de producción vinculado a las prácticas comunitarias, en base a la nacionalización de las tierras y su cesión a las comunidades indígenas, para que las trabajen bajo una dirección indigenista. Allí se inserta un imaginario más ligado probablemente a la Revolución Mexicana, más distante en el tiempo, y ya mediada por las lecturas tranquilizadoras de Manuel Gamio en Forjando Patria (1916) o de José Vasconcelos en La raza cósmica (1925), y por ello, más interesantes para un lector sobre el que nos parece se recorta la "nueva generación peruana", ideológicamente heterogénea, que ha atravesado la Reforma universitaria, y que una década después ocupa espacios significativos en el campo intelectual y en el Estado -como lo hicieron los propios Gamio y Vasconcelos en México-, no sólo en las Universidades sino también, como lo demuestra la trayectoria de Castro Pozo, ocupando lugares en el gobierno del primer Leguía. Mariátegui se detiene a aclararle a ese lectorado imaginado, que si la Revolución Mexicana-que caracteriza como un movimiento liberal- "por su inspiración y proceso les parece un ejemplo peligroso", pueden remitirse a los casos de Rumania y Checoslovaquia (Mariátegui [1928] 2011: 35).

Con respecto a la necesidad y a las características de la reforma agraria peruana, Mariátegui define sus objetivos y sus efectos: 
La necesidad más angustiosa y perentoria de nuestro progreso es la liquidación de esa feudalidad que constituye una supervivencia de la colonia. La redención, la salvación del indio, he ahí el programa y la meta de la renovación peruana. Los hombre nuevos quieren que el Perú repose sobre sus naturales cimientos biológicos. Sienten el deber de crear un orden más peruano, más autóctono. Y los enemigos históricos y lógicos de este programa son los herederos de la conquista, los descendientes de la colonia. Vale decir los gamonales. A este respecto no hay equívoco posible (Mariátegui [1928] 2011: 159).

En este punto, nos parece evidente que el ensayo es una invitación amplia a "los hombres nuevos", para que participen en desarrollar la política agraria de nacionalización de la propiedad de la tierra.

No obstante, como señalamos en la Introducción de este trabajo, es notable la pregnancia que ha tenido la representación del indígena revolucionario en las lecturas sobre los Siete ensayos... Intentaremos explicar las razones de la potencia con que circuló y sigue circulando, en un apartado dedicado específicamente a este tema.

Coordenadas epistemológicas de las representaciones:

el materialismo como límite al racialismo

En términos epistemológicos, las posibilidades de producir representaciones como las que analizamos se abren gracias al giro en el diagnóstico sobre los sujetos indígenas, habilitado por la articulación teórica con el materialismo histórico, modulado por lo que Mariátegui llama "puntos de vista socialistas" (Mariátegui [1928] 2011: 33). En torno a estas postulaciones, se reactiva la modulación científico-social del discurso de Mariátegui, apelando a la descripción económica y sociológica de la situación indígena. Allí Mariátegui recupera el espíritu de Manuel González Prada - a quien considera como precursor de la "nueva conciencia social"- al interpretar el "problema del indio" como un "problema económico-social" (Mariátegui [1920] 2011: 25). ${ }^{76}$

\footnotetext{
${ }^{76}$ En efecto, Mariátegui cita "Nuestros Indios" de González Prada en una nota al pie: "Nada cambia más pronto ni más radicalmente la psicología del hombre que la propiedad: al sacudir la esclavitud del vientre, crece en cien palmos. Con sólo adquirir algo el individuo asciende algunos peldaños en la escala social, porque las clases se reducen a grupos clasificados por el monto de la riqueza. A la inversa del globo aerostático, sube más el que más pesa. Al que diga: la escuela, respóndasele: la escuela y el pan. La cuestión del indio, más que pedagógica, es económica, es social" (Mariátegui [1928] 2011: 28).
} 
En ese sentido, por momentos el dispositivo representacional pierde intensidad, sobre todo al retratar la historia reciente y el presente, aunque recuperará su centralidad en la imaginación de la modernización a futuro:

Todas las tesis sobre el problema indígena, que ignoran o eluden a éste como problema económico-social, son otros tantos estériles ejercicios teoréticos, -y a veces sólo verbalescondenados a un absoluto descrédito. No las salva a algunas su buena fé. Prácticamente, todas no han servido sino para ocultar o desfigurar la realidad del problema. La crítica socialista lo descubre y esclarece, porque busca sus causas en la economía del país y no en su mecanismo administrativo, jurídico o eclesiástico, ni en su dualidad o pluralidad de razas, ni en sus condiciones culturales y morales. La cuestión indígena arranca de nuestra economía. Tiene sus raíces en el régimen de propiedad de la tierra. Cualquier intento de resolverla con medidas de administración o policía, con métodos de enseñanza o con obras de vialidad, constituye un trabajo superficial o adjetivo, mientras subsista la feudalidad de los "gamonales" (Mariátegui [1928] 2011: 25).

El punto de partida del ensayo es la lectura materialista de los problemas nacionales. El diagnóstico sobre el atraso y las trabas al desarrollo se centra en la consideración de que la tierra en manos de los terratenientes latifundistas de la sierra -en muchos casos robada a las comunidades indígenas- prolonga un modo de producción semifeudal que desaprovecha al indígena como factor productivo, y que determina la explotación semiesclavista del indígena (al que, enajenada la tierra, se le han sustraído los medios para subsistir material y espiritualmente). La consideración del latifundio está, además, vinculada con una mirada antiimperialista, que denuncia la presión de los países centrales sobre la demanda agro-exportadora, que resulta en una expansión del latifundio sobre las comunidades.

Como contrapartida, la instauración, en las tierras nacionalizadas por la reforma, de un modo de producción ligado a la tradición comunista indígena (articulable con un proyecto de nacionalización integral de la riqueza o, en palabras del autor, con "una política social de nacionalización de las grandes fuentes de riqueza" -Mariátegui [1928] 2011: 73- que se enuncia pero no se desarrolla) presenta, como la solución a la problemática demarcada por el ensayo, la mencionada reforma de la estructura de la propiedad agraria de la sierra.

Estas consideraciones hacen estallar los diagnósticos racialistas, e incluso difieren de las evaluaciones culturalistas, cuyo enfoque tiende a centrarse fuertemente en cuestiones ligadas a la identidad -popular y nacional-, y suelen sugerir una homogeneización cultural "desde arriba" que sutura los elementos en conflicto. Frecuentemente de esta mirada se deriva la prescripción de proyectos de mestizaje cultural, vía creación de valores para una identidad nacional, que relajen las inquietantes tensiones entre los indígenas y el resto de los actores que configuran la nación. Y si bien el ensayo tiene -como vimos- largas áreas y aristas de su 
interpretación vinculadas a las discusiones del culturalismo espiritualista, e incluso breves incursiones en la cuestión del mestizo y del mestizaje, éstas están en cierto modo contenidas en un diagnóstico y una propuesta materialistas, perspectiva que identifica el comienzo del problema de los indígenas e indica el camino de su finalización: la posesión de la tierra.

Estos elementos epistemológicos materialistas y culturalistas conviven, rearticulándose permanentemente en los Siete Ensayos..., y por momentos un discurso es llevado al primer plano de la reflexión, para ser enviado en otros momentos a un segundo plano y viceversa. Sin embargo, podemos sugerir una lógica circular (forma que evoca la lógica de la dialéctica, pero también el síntoma de una reflexión que se cierra permanentemente sobre sí misma) que los articula así: diagnóstico materialista, medios espiritualistas, fines materialistas: movimiento que puede observarse tanto en la apelación a la ética religiosa indígena para solucionar el problema de la tierra y por ende el problema indígena, como a la difusión de ideales sociales que promuevan reformas radicales, como la reforma agraria. Es importante remarcar, como veremos, que el ensayo no logra librarse por completo de algunas recaídas en el racialismo, al abordar las alteridades afrodescendientes y las provenientes de "oriente".

Si el inicio y el final del análisis tienen que ver con la tierra como dato material (la posesión o su ausencia), la posibilidad de obtenerla descansa en elementos espirituales: por una parte, como dijimos, en la reactivación de las costumbres y las normas que rigen éticamente el comportamiento de los indígenas para trabajar el suelo nacional; por otra, en la necesaria interpelación ideológica de un lectorado espiritualista para la conformación de una dirigencia indigenista que efectivice la reforma agraria.

Retomando a Terán (1986), podemos pensar que la perspectiva espiritualista dota al objetivo materialista (de nacionalizar la tierra y hacerla producir por parte del indígena) de mayor capacidad de traductibilidad nacional para su comprensión y para la adhesión al mismo.

\section{El "alma indigena": efectos de una lente distante}

Antes de proseguir con estas consideraciones, conviene dar cuenta de la sensación de lejanía y falta de profundidad que se percibe en las representaciones de los indígenas en lo que concierne a su condición de sujetos individualizables. En efecto, el discurso sociológico que despliega Mariátegui, intentando captar la totalidad social y económica que rodea la situación 
del indígena, genera un efecto de abstracción de las características del indígena en su especificidad y diversidad como ser humano, más allá de los elementos que señalamos más arriba, ligados a la cosmovisión religioso-productiva.

Es así que si bien Mariátegui construye representaciones en extremo positivas -si se las compara con las de los intelectuales de entresiglos, e incluso con las de los indigenistas contemporáneos-, la alteridad carece de atributos, quedando como una impresión potente pero vacía de los rasgos que en el período definen como parte del "el alma indígena", más distantes aún que las presentadas por la mirada arqueológica de Valcárcel, el costumbrismo del folclorismo modernista de Uriel García, o el registro etnográfico-folclórico de Castro Pozo.

De hecho, en los elementos señalados puede entreverse la perduración de residuos provenientes de las representaciones clisé de los intelectuales de entresiglos, que en su ambigüedad no quedan exentos de la reintroducción de ideologemas negativizadores de la alteridad indígena. Así, lo "primitivo", lo "rústico" -resemantizados por la mediación del primitivismo estético-, junto con el "sufrimiento" y la "despreocupación", pero también el "tesón", la "dulzura", el "buen sentido" y un "imaginismo" realista y sobrio, son las coordenadas repetidas del ensayo cuando avanza por fuera de las características ligadas al ya trabajado "agrarismo" del indígena.

A la abstracción totalizadora de los sujetos indígenas se le añade otra cuestión que refuerza el señalado síntoma de distanciamiento de Mariátegui con respecto a la alteridad. Las cualidades atribuidas al "alma indígena" son encontradas en los autores de la literatura que retrata lo indígena, más que en el indígena en sí mismo. Así “[Mariano] Melgar se muestra muy indio en su imaginismo primitivo y campesino" o "del indio tiene el Tunante [Abelardo Gamarra] la tesonera y sufrida naturaleza, la panteísta despreocupación del más allá, el alma dulce y rural, el buen sentido campesino, la imaginación realista y sobria" (Mariátegui [1928] 2011: 198). De ese modo, lo indígena aparece mediado en extremo por la mirada intelectual. La búsqueda de la alteridad sugiere un movimiento similar al de la apertura de una muñeca rusa: para llegar a lo indígena, se deben atravesar varios envoltorios intelectuales, para encontrar al final apenas unos trazos rápidos del sujeto indígena.

Nuevamente aparece una mirada del indígena mediada por la biblioteca, a diferencia de la emergente etnografía culturalista, más o menos científica, de los otros indigenistas. Creemos que esto se puede leer como un síntoma de la distancia de Mariátegui respecto a los sujetos indígenas, las comunidades, la sierra y aún de los sitios arqueológicos. Se trata de una distancia en un doble sentido: real, por la efectiva lejanía geográfica (cuya inaccesibilidad es 
aún mayor para un Mariátegui convaleciente) e imaginada, en tanto reproduce la separación simbólica entre indígenas e indigenistas, dominante en otros discursos previos y contemporáneos como los que abordamos en esta tesis.

Por último, cabe señalar que ese régimen de visibilidad de lo indígena no permite visualizar al indígena por fuera del ámbito rural, en particular en la ciudad, tópico que el ensayo deja en un sugerente silencio a pesar de que las migraciones indígenas al ámbito urbano ya son muy significativas en los años veinte. ${ }^{77}$

\section{Mestizos, mestizaje: recaídas en el racialismo}

y funciones ideológicas de la "literatura nacional"

De manera similar al tratamiento del "alma indígena", Mariátegui aborda las concepciones del mestizo y el mestizaje en el marco de sus indagaciones sobre la literatura nacional, que realiza en el extenso capítulo final, "El proceso de la literatura". En esta clave, el mestizaje es interpretado en base a un movimiento idéntico, de acuerdo al cual literatura y sociedad se reflejan, o mejor se intermedian. Su concepción del mestizaje oscila entre una interpretación social, ligada a la mezcla de sujetos y culturas, y una concepción del mestizaje en la literatura, evaluada en torno a la idea normativa de que el proceso de mestizaje, para concretarse, requiere de una forma literaria que unifique la mezcla. El resultado de esa mezcla es simultáneamente una "literatura nacional" y un "pueblo". Así, ese movimiento pendular del discurso, entre sociedad y literatura, marca el particular abordaje del mestizaje que hace Mariátegui, al considerarlo como un proceso trunco. Detengámonos a observarlo. Por ejemplo, advierte que

...destruida la civilización inkaica por España, constituido el nuevo Estado sin el indio y contra el indio, sometida la raza aborígena a la servidumbre, la literatura peruana tenía que ser criolla, costeña, en la proporción en que dejara de ser española. No pudo por esto, surgir en el Perú una literatura vigorosa. El cruzamiento del invasor con el indígena no había producido en el Perú un tipo más o menos homogéneo. A la sangre íbera y quechua se había mezclado un copioso torrente de sangre africana. Más tarde la importación de coolís debía añadir a esta mezcla un poco de sangre asiática. Por ende, no había un tipo sino diversos tipos de criollos, de mestizos. La fusión de tan disímiles elementos étnicos se cumplía, por otra parte, en un tibio y sedante pedazo de tierra baja, donde una naturaleza indecisa y negligente no podía imprimir en el blando producto de esta experiencia sociológica un fuerte sello individual (Mariátegui [1928] 2011: 180; cursivas nuestras).

\footnotetext{
${ }^{77} \mathrm{Al}$ respecto ver el Capítulo I de esta tesis y Klarén (1991 y 2004) y Desustua y Renique (1984).
} 
La presencia avasallante de España (ligada a la tradición colonial y emblema cultural de los intelectuales conservadores de entresiglos), y la presencia en la mezcla de "sangre" africana y asiática (que complica, en palabras del autor, la mezcla), son los ejes del fracaso del mestizaje. La determinación telúrica del medio se presenta en su sentido más negativo, en la consideración de la tibieza soporífera del espacio geográfico de la costa peruana. Nótese cómo el abordaje del mestizaje trae consigo la reemergencia, episódica y marginal en el ensayo, de una mirada que arrastra resabios de los prejuicios racialistas que históricamente, en Perú, condenan el mestizaje y devalúan fuertemente a las alteridades sociales afrodescendientes y asiáticas.

El negro ha mirado siempre con hostilidad y desconfianza la sierra, donde no ha podido aclimatarse física ni espiritualmente. Cuando se ha mezclado al indio ha sido para bastardearlo comunicándole su domesticidad zalamera y su psicología exteriorizante y mórbida. Para su antiguo amo blanco ha guardado, después de su manumisión, un sentimiento de liberto adicto. La sociedad colonial, que hizo del negro un doméstico - muy pocas veces un artesano, un obrero- absorvió y asimiló a la raza negra, hasta intoxicarse con su sangre tropical y caliente (Mariátegui [1928] 2011: 251).

El abordaje de los afrodescendientes apela a estereotipos y clisés que van de la peligrosidad a la adicción a la esclavitud, cuando no a una domesticidad que le imprime sentidos feminizadores a la negritud. El vocabulario del racialismo retorna en todo su esplendor cuando se enuncia que lo afro inserta "sangre tropical y caliente" que enferma a los demás componentes de la mezcla. En otras páginas retoma el tema, prolongando la condena:

El aporte del negro, venido como esclavo, casi como mercadería, aparece más nulo y negativo aún. El negro trajo su sensualidad, su superstición, su primitivismo. No estaba en condiciones de contribuir a la creación de una cultura, sino más bien estorbarla con el crudo y viviente influjo de su barbarie (Mariátegui [1928] 2011: 257; cursivas nuestras).

Sensual, supersticioso y primitivo, el autor lo vincula explícitamente con la barbarie que estorba la creación de la cultura nacional. La consideración de que el afrodescendiente puede redimirse gracias a la activación, por parte del socialismo, de la consciencia de clase, capaz de producir un quiebre en el espíritu colonial (Mariátegui [1928] 2011: 251-252), en juego con la ruptura de las miradas racialistas (desde coordenadas del materialismo histórico), no llega aquí a evitar eficazmente la reactivación de los ideologemas que negativizan la herencia africana, prolongando esa mirada casi en su totalidad. 
El mismo procedimiento y la misma conclusión se le aplica a la alteridad asiática (aunque paradójicamente, China y Rusia, como "civilizaciones", no quedarán vinculadas a la caracterización negativa de Oriente):

El chino y el negro complican el mestizaje costeño. Ninguno de estos dos elementos ha aportado aún a la formación de la nacionalidad valores culturales ni energías progresivas. El culí chino es un ser segregado de su país por la superpoblación y el pauperismo. Injerta en el Perú su raza, mas no su cultura. La inmigración china no nos ha traído ninguno de los elementos esenciales de la civilización china, acaso porque en su propia patria han perdido su poder dinámico y su generador. Lao Tsé y Confucio han arribado a nuestro conocimiento por la vía de Occidente. La medicina china es quizá la única importación directa de Oriente, de orden intelectual, y debe, sin duda, su venida a razones prácticas y mecánicas, estimuladas por el atraso de una población en la cual conserva hondo arraigo el curanderismo en todas sus manifestaciones. La habilidad y excelencia del pequeño agricultor chino, apenas si han fructificado en los valles de Lima, donde la vecindad de un mercado importante ofrece seguros provechos a la horticultura. El chino, en cambio, parece haber inoculado en su descendencia, el fatalismo, la apatía, las taras del Oriente decrépito. El juego, esto es un elemento de relajamiento e inmoralidad, singularmente nocivo en un pueblo propenso a confiar más en el azar que en el esfuerzo, recibe mayor impulso de la inmigración china. Sólo a partir del movimiento nacionalista, -que tan extensa resonancia ha encontrado entre los chinos expatriados del continente-, la colonia china ha dado señales activas de interés cultural e impulsos progresistas (Mariátegui [1928] 2011: 257; cursivas nuestras).

Los "chinos" migran sin su cultura -valorada en términos civilizatorios por Mariátegui y por su presente nacionalista-, por lo que no han aportado nada positivo a la mezcla. Traen, por el contrario, el influjo retardatario del "Oriente decrépito". El lenguaje médico se reactiva para advertir sobre la inoculación de fatalismo, apatía e inmoralidad. La vinculación al juego y al opio completa una concepción que incluso llega a criminalizar a los asiáticos. Sólo se les reconoce el aporte en materia de medicina, cuya incorporación contribuye a fortalecer el curanderismo popular. Y si bien nuevamente la ideología los puede salvar -en este caso, el nacionalismo-, parece no haber remedio para esos componentes étnicos, que quedan invisibilizados en casi todo el ensayo, una vez terminada su condena.

Por el contrario, como vimos a lo largo de este capítulo, la representación del mundo indígena mantiene una semantización positiva. Es más, lo indígena parece dar al devaluado mestizaje, una modalidad efectiva y promisoria, habilitada por la consideración telúrica del espacio andino, tal como ocurría - con diversos matices- en los ensayos de los indigenistas cusqueños. El autor apela a José Uriel García para mostrar un mestizaje promisorio en la sierra, como oposición al espacio de la costa, que le da un carácter blando y una impronta hispánica. 
El mestizaje es un fenómeno que ha producido una variedad compleja, en vez de resolver una dualidad, la del español y el indio./ El Dr. Uriel García halla el neo-indio en el mestizo. Pero este mestizo es el que proviene de la mezcla de las razas españolas e indígena, sujeta al influjo del medio y la vida andinas. El medio serrano en el cual sitúa el Dr. Uriel García su investigación, se ha asimilado al blanco invasor. Del abrazo de las dos razas, ha nacido en nuevo indio, fuertemente influído por la tradición y el ambiente regionales./ Este mestizo que en proceso de varias generaciones y bajo la presión del medio telúrico y cultural ha adquirido ya rasgos estables, no es el mestizo engendrado en la costa por las mismas razas. El sello de la costa es más blando, el factor español, más activo (Mariátegui [1928] 2011: 256).

La influencia telúrica del medio se pone en primer plano para dar otro sentido posible al mestizaje. En Cusco - tal como afirman García, pero también Valcárcel en algunos derroteros de los ensayos abordados en el trabajo- establece la potencialidad de un mestizaje donde, por la influencia del medio, lo indígena asimila la cultura del blanco europeo.

Hay en el ensayo otra aseveración que remarca esos sentidos positivos: paradójicamente, el fin del mestizaje por el borramiento que opera el influjo de las ciudades modernas, que en el ensayo se identifican con Rusia, pero también con una Lima posible. Efectivamente, la ciudad industrial asimila el "sórdido" y "morboso" (Mariátegui [1928] 2011: 259) producto del mestizaje:

Si la cuestión racial -cuyas sugestiones conducen a sus superficiales críticos a inverosímiles razonamientos- es artificial y no merece la atención de quienes estudian concreta y políticamente el problema indígena, otra es la índole de la cuestión sociológica. El mestizaje descubre en este terreno sus verdaderos conflictos, su íntimo drama. El color de la piel se borra como contraste, pero las costumbres -los sentimientos, los mitos, los elementos espirituales y formales de esos fenómenos que que se designan con los términos sociedad y cultura- reivindican sus derechos. El mestizaje, -dentro de las condiciones económico-sociales subsistentes entre nosotros-, no sólo produce un nuevo tipo humano y étnico sino un nuevo tipo social; y si la imprecisión de aquel, por una abigarrada combinación de razas, no comporta en sí misma una inferioridad, y hasta puede anunciar en ciertos ejemplares felices, los rasgos de la raza "cósmica", la imprecisión o hibridismo del tipo social, se traduce por un oscuro predominio de sedimentos negativos, en una estagnación sórdida y morbosa [...] Dentro de un ambiente urbano, industrial, dinámico, el mestizo salva rápidamente las distancias que lo separan del blanco, hasta asimilarse a la cultura occidental, con sus costumbres, impulsos y consecuencias [...] En contacto con una civilización maquinista, asombrosamente dotada para el dominio de la naturaleza, la idea del progreso, por ejemplo, es de un irresistible poder de contagio o seducción. Pero este proceso de asimilación o incorporación se cumple prontamente sólo en un medio en el cual actúan las energías de una cultura industrial (Mariátegui [1928] 2011: 259; cursivas nuestras).

En este párrafo se expresa contradictoriamente una mirada positiva sobre del mestizaje, en el que la referencia a la "raza cósmica" de Vasconcelos no implica la adopción de la tesis de $L a$ raza cósmica (1925) criticada en otras páginas del ensayo (Mariátegui cita Indología -1926del autor mexicano, mientras que La raza cósmica es sólo abordado en términos generales). 
La reivindicación es, como podemos observar, netamente espiritualista, y tiene una connotación asimilacionista. Luego de un difuso rechazo del racialismo, el autor se posiciona desde lo que llama "cuestión sociológica", para dar centralidad a los procesos de mezcla en las costumbres, definidas como sentimientos, mitos, elementos espirituales y formales, que engloba bajo los términos de "sociedad" y de "cultura". El énfasis en esos elementos vuelve a reactivar, una vez más, los sentidos espiritualistas del ensayo. Desde ese punto de vista, la escritura tiene una función central en la movilización de estos elementos espirituales unificadores, ya que para Mariátegui incluso "la nación es un mito" (Mariátegui [1928] 2011: 174).

En consecuencia, el abordaje de la subjetividad indígena -analizado más arriba- y del mestizaje, en el marco de la crítica de la literatura peruana, abre una veta interesante para pensar la práctica intelectual en su dimensión representacional, literaria y más ampliamente estética. La representación literaria, o de modo más general la escritura poducida por parte de intelectuales y artistas, genera y transforma la sociedad y la cultura. Por ende, interpreta, interpela y crea "lo popular", en un movimiento de captación-representación-transformación. En sintonía con las reflexiones de Antonio Gramsci en sus Cuadernos de la cárcel, sobre el papel de la literatura en la configuración de lo social, Mariátegui advierte que

El florecimiento de las literaturas nacionales coincide, en la historia de Occidente, con la afirmación política de la idea nacional. Forma parte del movimiento que, a través de la Reforma y el Renacimiento, creó los factores ideológicos y espirituales de la revolución liberal y el orden capitalista (Mariátegui [1928] 2011: 174; cursivas nuestras).

La consideración de la unidad nacional, que puede y debe generar la literatura, no implica sin embargo una valoración del mestizaje hasta ahora realizado, que se coloca en un segundo plano en el resto del ensayo, hasta quedar por silenciado por completo. Lo indígena (del pasado y del presente) debe ser el tema articulador central de la nueva cultura. He aquí otra de las grandes apuestas/invitaciones del ensayo, para con la nueva generación peruana: producir, desde diversos lenguajes estéticos, un imaginario de la modernización de Perú que tenga al "indio" en un lugar central de su discurso. La literatura tiene también la misión de movilizar la concreción de ese imaginario, en el marco de una transformación social efectiva. Sin embargo, esta función asignada prolonga un gesto elitista en la concepción de la acción intelectual. Nuevamente se hacen presentes, en torno a estas consideraciones, los elementos del espiritualismo arielista tamizados por una mirada que hace foco en lo social. El espiritualismo termina situándose así por encima de toda la trama de enunciados que 
componen el discurso de los Siete ensayos..., apuntando a la producción de ideales sociales que, desde la literatura y el arte, sean capaces de generar acción y transformación en la sociedad. Tiene por ende una tarea social, nacionalista, civilizatoria: crear un Perú unido y moderno en torno a esas representaciones. Parafraseando a Starobinski (1999: 22), nos parece que, en el modelo de literatura que se propone, "lo sagrado de la civilización toma el relevo de lo sagrado de la religión". Estas postulaciones refractan, además, la concepción de la religión en la historia que, tal como vimos, aparece en el mismo ensayo, demostrando además la profunda compatibilidad del pensamiento de Mariátegui con respecto al misticismo vehiculado por las vanguardias estéticas y por el primitivismo en general (al concebir el arte como sustituto de la religión): la religión en el Imperio Inca, y la literatura en el presente, parecen fijarse las mismas metas orientadoras de la acción social. Por contigüidad, la dirigencia inca antes, y los intelectuales indigenistas hoy, son quienes han provisto esos “ideales sociales" en el pasado, y quienes deben seguir proveyéndolos en el presente. Podemos conectar esta inferencia con lo que Mariátegui afirma en el último párrafo del "El factor religioso", apelando nuevamente a la autoridad intelectual de Sorel: "Como lo anunciaba Sorel, la experiencia histórica de los últimos lustros ha comprobado que los actuales mitos revolucionarios o sociales pueden ocupar la conciencia profunda de los hombres, con la misma plenitud que los antiguos mitos religiosos" (Mariátegui [1928] 2011: 142).

Como vimos, los elementos espirituales gravitan en dos grandes temas del ensayo: el que identifica y señala la presencia de una ética del trabajo en los indígenas, y el que promueve una práctica intelectual de representación imaginaria para una tradición nacional unificadora de Perú. Es interesante remarcar que estas dos cuestiones, estas dos tareas, van direccionadas hacia dos diferentes sujetos. Los indígenas de la sierra trabajarán en las tierras nacionalizadas a partir de la reactivación de su agrarismo. Los escritores, artistas, científicos sociales, antropólogos, economistas y sociólogos, producirán un imaginario nacional que integre y unifique lo indígena a la nación. Ambas tareas parecen reclamar la dirección de los intelectuales que -recortados una vez más sobre el tipo de dominación atribuida a la realeza inca- deben orientar ambos hechos en un mismo sentido social y transformador, mediante la provisión de "ideales sociales" modernizadores:

El "mujikismo" tuvo parentesco estrecho con la primera fase de agitación social en la cual se preparó y se incubó la revolución rusa. La literatura "mujikismo" llenó una misión inapelable. Constituyó un verdadero proceso del feudalismo ruso, del cual salió éste inapelablemente condenado. La socialización de la tierra, actuada por la revolución bolchevique, reconoce 
entre sus pródromos la novela y la poesía "mujikistas"[...]/ De igual modo el "constructivismo" y el "futurismo", que se complacen en la representación de máquinas, rascacielos, aviones y usinas, etc. corresponden a una época en que el proletariado urbano, después de haber creado un régimen cuyos usufructuarios son hasta ahora los campesinos, trabaja por occidentalizar Rusia llevándola a un grado máximo de industrialismo y electrificación (Mariátegui [1928] 2011: 247).

De ese modo, como lo muestra el ejemplo de la literatura y el arte rusos previos y contemporáneos a la Revolución, las prácticas representacionales, tanto en sus vertientes más tradicionales como en las más vanguardistas, resultan un aporte fundamental para la modernización de las sociedades.

\section{Arielismo y marxismo}

La insistente aparición de elementos espiritualistas nos lleva a preguntarnos por la relación entre espiritualismo y materialismo histórico, o si se quiere entre arielismo y marxismo. ¿Qué lugar ocupa en la interpelación del campo intelectual de los años veinte?

En su artículo "Filosofía y revolución en los escritos de Mariátegui", José Sazbón reflexiona sobre la coexistencia, en el pensamiento del intelectual peruano, de inscripciones ideológicas y posiciones filosófico-sociales de compleja articulación, en el que una perspectiva política de clase es dinamizada a partir de marcos filosóficos idealistas (Sazbón, 2002: 118). Para Sazbón (2002: 114), la presencia de esos encuadres idealistas, visibles en inflexiones vitalistas, irracionalistas, espiritualistas, voluntaristas y misticistas, en las inmediaciones de esa perspectiva de clase que persigue la emancipación del proletariado, es el dato fundamental del marxismo de Mariátegui respecto de otros marxismos de su época. "Socialismo voluntarista" (Sazbón, 2002: 116), "romanticismo revolucionario" (Sazbón, 2002: 122; Kohan, 2000: 97), “idealismo revolucionario" (Terán, 1986: 111), “marxismo romántico" o "marxismo arielista" (Löwy, 2000: 12) son algunos de los rótulos ensayados para catalogar esta atípica matriz ideológica que, en consonancia con la reacción antipositivista de las primeras décadas del siglo XX, recupera el mito como "configuración espiritual activadora, como impulso ideal" capaz de desatar las energías necesarias para la transformación de la sociedad (Sazbón, 2002: 132-133).

Sazbón señala la influencia de Sorel en la articulación filosófico-ideológica mariateguiana, pero tiene la virtud de no presentarla ni como su única influencia, ni de reducirla a una mera operación de traducción al contexto local (como hace, por ejemplo, 
Villaverde Alcalá-Galeano en el libro clásico de Aricó). ${ }^{78}$ Por el contrario, considera que Sorel funciona como "aglutinante" y/o "totalizador potencial" de otras diversas influencias, entre las que señala a pensadores del centro -Nietzche, Croce, Bergson, Spengler, Gobeti, Romain Rolland- pero también locales, como por ejemplo Vasconcelos, Ingenieros o Waldo Frank (Sazbón, 2002: 120). Nos interesa en particular la referencia a las influencias locales, ya que trae a colación una arista poco problematizada en los estudios mariateguianos: la relación entre la tradición intelectual local y esa articulación singular entre idealismo y marxismo. Como trataremos de demostrar, la combinación de idealismo y marxismo ocupa un lugar central entre las estrategias desplegadas por Mariátegui para reconducir el campo intelectual, y sobre todo a la "nueva generación", hacia posiciones socialistas, incluyendo a los indigenistas considerados en esta tesis. La formulación -apelando a Sorel- del mito del socialismo peruano ocupa un lugar central ya que, al suplantar la noción de "ideal”, permite recuperar buena parte de la lectura arielista de la realidad nacional, potenciando la traductibilidad nacional del marxismo, para redireccionarlo en sus metas y objetivos, hacia una mirada sensible a problemáticas económico-sociales. En otras palabras, al insertar el mito del socialismo peruano en la cosmovisión arielista, Mariátegui busca apropiarse de algunos núcleos de "buen sentido" de la mirada arielista, con el objetivo de radicalizar el campo intelectual peruano, intentando "un enderezamiento del espiritualismo sobre sus pies" (Sazbón, 2002: 146), que lo oriente hacia la acción política.

Ahora bien, ¿qué efectos tiene esa incorporación de nociones de "ideal social" y de "mito" en las estrategias desplegadas por Mariátegui hacia el campo intelectual, sin desconocer que esas mismas categorías adquieren modulaciones diferentes cuando -como vimos- las piensa en relación al lugar de los indígenas en la sociedad?

Durante el primer tercio del siglo XX, la gravitación de encuadres filosóficos idealistas fue muy intensa en los ámbitos intelectuales de todo el continente. En 1900, la salida del Ariel de Rodó propaga la reacción antipositivista en los ámbitos intelectuales de América Latina, contribuyendo a forjar una nueva sensibilidad que antepone la belleza a la utilidad, y el arte a la ciencia, y que encuentra en lo espiritual un refugio ante el materialismo y la fragmentación de la experiencia en la modernización capitalista, identificada con los Estados Unidos, y representada -en el ensayo de Rodó- por medio de la amenazante figura de Calibán. ${ }^{79}$ Como afirma Terán,

\footnotetext{
${ }^{78}$ Aricó (1980).
} 
...la noción de ideal ocupaba un lugar central en esta constelación espiritualista. Ideal, por un lado, refiere a valores de índole espiritual que escapan al ordenamiento positivista y materialista, y que como tales fundan la posibilidad de una moral [;] por el otro, se vinculaba con la noción de "ideas-fuerza" de Fouillé, es decir, con aquellas ideas que por sólo el hecho de tenerlas se traducen en acción” (Terán, 2010: 56).

De allí que una de las claves del pensamiento arielista sea proveer los ideales morales capaces de superar esa crisis en la que se considera que se ha introducido la modernidad. Desde la perspectiva de Rodó, la tarea de formular y proveer esos ideales queda a cargo de una elite del mérito, de una aristarquía de la moral y la cultura que viene a ser el reaseguro contra el avance generalizado e inevitable de las mediocracias modernas.

En sintonía con este clima de ideas, ya finalizada la primera década del siglo XX, Ingenieros publica El hombre mediocre (1913). En este ensayo, que también adquiere gran resonancia a nivel continental y una rápida recepción en los círculos intelectuales, se observa la emergencia de inquietudes filosóficas e incrustaciones espiritualistas en el pensamiento de Ingenieros que, no sin tensiones con la veta positivista que continúa activa, llevan al centro de su pensamiento la noción de "ideal". ${ }^{80}$

En Perú, la gravitación de esta matriz espiritualista adquiere gran peso en el campo intelectual. Tal es así que la formación que emerge, en entresiglos es denominada "arielista" por su fuerte identificación con el pensamiento de Rodó. Estos intelectuales, entre los que cabe destacar a los hermanos Francisco y Ventura García Calderón, José de la Riva Agüero y Víctor Andrés Belaúnde, fueron los primeros en reflexionar sobre Perú de modo sistemático y global, con el objetivo de formular un proyecto nacional modernizador (Gonzáles, 1996). Nos interesa destacar que la reflexión de estos autores sienta un precedente ineludible en el campo intelectual peruano de las primeras tres décadas del siglo XX, siendo referencia obligada para todos aquellos que reflexionan sobre diferentes aspectos de la sociedad peruana, ya sea para pensar con ellos, o contra ellos -y en esto Mariátegui no parece ser una excepción-. Instituyen un marco y un modo de pensar, y también los temas que ocupan el centro de la reflexión intelectual durante buena parte del siglo XX: la identidad nacional, el problema del

\footnotetext{
${ }^{79}$ Este movimiento de ideas en nuestro continente se da de manera paralela con un retorno a los encuadres idealistas en la filosofía moderna en los países centrales: vitalismo en Bergson, psicologismo en Wundt, emergencia de corrientes neokantianas, neohegelianas, esto es, neoidealistas en general, a las que también pertenecen Sorel, Croce, Gentile y Romain Rolland.
}

${ }^{80} \mathrm{Al}$ respecto ver Mailhe (2013a). 
indio, el lugar de Perú en el continente, el rechazo a la injerencia norteamericana, la industrialización y la postulación de la necesidad de un proyecto nacional (Gonzáles, 1996: 52). En términos generales, pasan a ser reconocidos por el énfasis culturalista presente en las respuestas que dan a estos problemas, vinculados con la creación de una identidad nacional y continental, y en donde la noción de "ideal" -clásico, hispánico, latino- ocupa un lugar central. No pretendemos desconocer la veta modernizadora, en sentido capitalista, de Perú -práctica, pragmática, material- que hay en el pensamiento de los arielistas (Gonzáles, 1996: 222), pero nos interesa enfatizar el rol que cumplen en la sedimentación, en el campo intelectual peruano, de elementos idealistas vinculados con la tradición instituida por el Ariel de Rodó. Las formaciones intelectuales que emergen hacia el segundo lustro de la década de 1910, como la "juventud peruana" luego reconfigurada -Reforma Universitaria y Revolución Rusa mediante- bajo la identificación de la "nueva generación peruana", van a sentirse también convocadas por el Ariel para emprender una rebelión "idealista" contra los valores positivistas del estado oligárquico, y contra la "decadencia" moral de las clases dirigentes (Beigel, 2006: 60-62). En efecto, como señala Portantiero, el movimiento de la Reforma Universitaria tiene, tanto en Perú como en el resto del continente, mucho del romanticismo idealista del Ariel (Portantiero, 1978: 72).

Ahora bien; tal como señala Fernanda Beigel (2006: 143), la "nueva generación" es un sujeto colectivo heterogéneo que contiene en su interior proyectos de diferente grado de radicalidad: desde reformistas moderados (que no trascienden la crítica a la impermeabilidad de las instituciones oligárquicas para las nuevas elites juveniles portadoras del "ideal"), hasta grupos que comienzan a abandonar el juvenilismo rodoniano, para dirigirse hacia posiciones antiimperialistas y/o marxistas, postulando una necesidad de transformación radical de la sociedad que trascienda el mero ámbito universitario e institucional. Al reflexionar sobre las prácticas artísticas en los años veinte peruanos, Beigel (2003: 34) sugiere que la nueva generación puede ser considerada como el puente entre el Modernismo y la vanguardia. Proponemos retomar esa comparación para, posicionados en las coordenadas filosófico-sociales que nos ocupan, pensar la nueva generación como un espacio de tránsito entre el espiritualismo arielista y el marxismo romántico (no importa que sean pocos los que lo hayan transitado). Entender la nueva generación como un área de pasaje y de disputas, donde lo activo, lo residual y lo emergente coexisten conflictivamente, y donde la noción de “ideal" se tensa entre sentidos divergentes, nos permitirá comprender mejor las apuestas de Mariátegui con respecto al campo intelectual. Entre los años 1923 y 1928, se desarrolla un "proceso de definiciones programáticas e ideológicas" en el que Mariátegui intervendrá para 
impulsar la radicalización (Beigel, 2006: 29). La estrategia principal es vincular la noción de "ideal" con la de ideales sociales y con el mito en sentido soreliano, con el objetivo de establecer un nexo entre las difusas aspiraciones de la nueva generación y las premisas organizativas y políticas que demandan las luchas sociales, pero sin romper con los encuadres idealistas ni con sus portadores (Sazbón, 2002: 134).

Terán (1985: 115) afirma que "una ideología sólo deviene orgánicamente operativa cuando concentra una posibilidad de traductibilidad nacional". En los artículos que analizaremos a continuación, Mariátegui intenta optimizar la traductibilidad del marxismo en Perú a partir de la sustitución de la noción de "ideal" por la de "ideal social" y "mito revolucionario" en el interior de la matriz filosófica arielista. Con ello, intentará conducir a los sujetos de la nueva generación, que están todavía filiados al espiritualismo arielista, hacia posiciones revolucionarias, favoreciendo un proceso de radicalización que parece estar pensado como un tránsito, y no como una ruptura, ya que, más que una negación de las posiciones filosóficas idealistas, Mariátegui parece proponer un reordenamiento de las mismas para cargarlas con otro sentido ideológico. Como han señalado Terán (1986) y Beigel (2003) entre otros, la tolerancia de los discursos no marxistas -que no compromete, por supuesto, la opción clasista de Mariátegui- es un rasgo fundamental de su "heterodoxia". No sólo el espiritualismo arielista que aquí nos ocupa, sino también -por ejemplo- el psicoanálisis, o los postulados de las vanguardias locales y europeas, pocos años después condenados por la ortodoxia marxista como "desviaciones pequeño-burguesas", serán saberes y discursos válidos para el director de la editorial Minerva. Fernanda Beigel ha señalado que esta apertura es un aspecto central del proyecto de Mariátegui durante el período de definiciones ideológicas iniciado en 1923, y que toma la forma de una "política de inclusión" en su emprendimientos editoriales (Beigel, 2003: 53). Dicha práctica busca interpelar a todos los sujetos que pueden contribuir a reflexionar críticamente sobre la sociedad peruana, para al mismo tiempo generar debates y enfrentamientos de ideas que puedan decantar en un proyecto de transformación social, que para Mariátegui debe tomar la forma de una revolución socialista (Beigel, 2003: 53; 2006: 199). 
Ahora bien; a partir del análisis de los ensayos de Valcárcel, García y Castro Pozo que hemos realizado en este trabajo, no es osado afirmar que tanto Tempestad en los Andes, como El nuevo indio, y en menor medida Nuestra comunidad indigena, tienen pocos puntos de contacto con el materialismo histórico contenido en "El problema del indio" en particular, y con el nacionalismo en general que presenta Mariátegui en sus Siete ensayos...

¿Cómo interpretar, entonces, la convergencia de Valcárcel, García y Mariátegui en un mismo espacio material y simbólico, esto es, en las mismas redes intelectuales, en los mismos proyectos editoriales y en áreas próximas del discurso social?

Se ha denominado "nueva generación" al sujeto colectivo que empieza a conformarse en oposición al régimen de Leguía durante los años veinte. Más allá de ese común denominador, la "nueva generación” es, como afirma Beigel (2006), profundamente heterogénea. Convergen allí las vertientes tanto estéticas como políticas de las vanguardias latinoamericanas de la época (Beigel, 2006: 43). Esta tensión, constitutiva en la formación de este nuevo actor, tiene su momento de mayor intensidad en el período comprendido entre los años 1923 y 1928, lustro en el cual se desarrolla un "proceso de definiciones programáticas e ideológicas" (Beigel, 2006: 29).

Mariátegui la define así, en su lectura del proceso de la Reforma Universitaria:

El movimiento estudiantil que se inició con la lucha de los estudiantes de Córdoba, por la reforma de la Universidad, señala el nacimiento de la nueva generación latinoamericana [...] La chispa de la agitación es casi siempre un incidente secundario; pero la fuerza que la propaga y la dirige viene de ese estado de ánimo, de esa corriente de ideas que se designa -no sin riesgo de equívoco- con el nombre de "nuevo espíritu". Las esperanzas mesiánicas, los sentimientos revolucionarios, las pasiones místicas propias de la posguerra, repercutían particularmente en la juventud universitaria de Latino-América. El concepto difuso y urgente de que el mundo entraba en un ciclo nuevo, despertaba en los jóvenes la ambición de cumplir una función heroica y de realizar una obra histórica. La crisis mundial invitaba a los pueblos latinoamericanos, con insólito apremio, a resolver sus problemas de organización y crecimiento. Lógicamente la nueva generación sentía estos problemas con una intensidad y un apasionamiento que las anteriores generaciones no habían conocido (Mariátegui [1928] 2011: 89). 
Para Beigel, "el proyecto mariateguiano cabalga sobre el proceso de definiciones ideológicas de la 'nueva generación'” (Beigel, 2006: 29). Ésta puede ser una de las claves para responder la pregunta que nos hacíamos más arriba, sobre el porqué de la proximidad de intelectuales y discursos como los de Valcárcel, García y Mariátegui, que presentan sensibles diferencias epistemológicas, políticas e ideológicas.

De ahí que, como afirma Beigel, la apertura sea un aspecto central del proyecto de Mariátegui durante el período de definiciones ideológicas, que adopta la forma de una "política de inclusión" en sus emprendimientos editoriales (Beigel, 2003: 53). En 1927 explicita esa meta, al decir que Amauta "no es todavía un programa sino apenas un debate en el cual caben voces e ideas diversas, que se reconozcan animadas del mismo espíritu de renovación" (AA.VV. [1927] 1975: 73). Y profundiza:

Somos los vanguardistas, los revolucionarios. Los que tenemos una meta, los que sabemos a dónde vamos. En el camino no nos alarma discutir con quienes no andan aún definitivamente orientados. Estamos dispuestos todos los días a confrontar nuestros puntos de vista con los afines o próximos./ [...] Yo, personalmente, traigo a ese debate mis proposiciones. Trabajaré, por supuesto, porque (sic) prevalezcan; pero me conformaré con que influyan -en la acción, en los hechos, prácticamente-, en la medida de su coincidencia con el sentimiento de mi generación y con el ritmo de la historia./[...] Nuestra ideología, nuestro espíritu, tienen que aceptar precisamente un trabajo de contrastación constante. Este es el único medio de concentrar y polarizar fuerzas, y nosotros - no lo ocultamos- nos proponemos precisamente ese resultado. Tenemos confianza en nuestra obra -no por lo iluminado o taumatúrgico o personal de su inspiración- sino por el carácter de interpretación y coordinación de un sentimiento y de un ideal histórico (AA.VV. [1927] 1975: 92-93).

Siguiendo esta línea interpretativa, encontramos que la "política de inclusión" de Mariátegui es acompañada por una serie de intervenciones intelectuales sobre el ensayo y la literatura indigenistas de los años veinte, orientadas a conectar indigenismo y marxismo, ${ }^{81}$ con el objetivo de dar entidad a una formación intelectual indigenista radical, e incluso con el objetivo de inventarla. A continuación, analizaremos el caso de las operaciones desplegadas por Mariátegui sobre Tempestad en los Andes.

81 Hemos analizado, en esta misma dirección, otra intervención de Mariátegui orientada a reconducir ideológicamente la producción y la trayectoria de José Ingenieros hacia un sentido socialista radical, en Castilla (2012). 
Tomando algunas claves provistas por Bourdieu (1999), para pensar las operaciones simbólicas que acompañan la circulación de las ideas, intentaremos describir y analizar las prácticas interpretativas llevadas a cabo por el marxista peruano, frente a este discurso paradigmático del indigenismo antropológico contemporáneo.

Mariátegui redirecciona el sentido ideológico del discurso de Valcárcel, orientándolo en favor de su propia perspectiva revolucionaria. En efecto, en el "Prólogo" a Tempestad en los Andes (luego incorporado como nota al pie al ensayo "El problema del indio" en Siete ensayos...), ${ }^{82}$ Mariátegui despliega una particular estrategia de apropiación creativa del discurso y de las representaciones construidas por Valcárcel en este ensayo.

Como dijimos, Mariátegui publica Tempestad en los Andes de Valcárcel en Lima, en su propia editorial Minerva, incluyéndolo en la colección "Biblioteca Amauta". Esta marcación establece una afiliación directa con su proyecto editorial e intelectual personal, cristalizado en buena medida en su revista homónima Amauta (1926-1930). La importación del discurso de Valcárcel a Lima (y la consecuente desvinculación de su contexto de enunciación cusqueño, al que Mariátegui no hace referencia alguna en su prólogo) amplía la dirección hermenéutica implícita en su operación de lectura. Allí Mariátegui instala un dispositivo ideológico de recepción que enmarca las representaciones de Tempestad en los Andes a partir de la concepción del mito en la teoría de Sorel:

La obra que ha escrito no es una obra teórica y crítica. Tiene algo de evangelio y hasta algo de apocalipsis. Es la obra de un creyente. Aquí no están precisamente los principios de la revolución que restituirá a la raza indígena a su sitio en la historia nacional; pero aquí están sus mitos. Y desde que el alto espíritu de Jorge Sorel, reaccionando contra el mediocre positivismo de que estaban contagiados los socialistas de su tiempo, descubrió el valor perenne del Mito en la formación de los grandes movimientos populares, sabemos bien que éste es un aspecto de la lucha que, dentro del más perfecto realismo, no debemos negligir ni subestimar (Mariátegui [1927] 1970: 15).

Esa clave de lectura (magnificada por la posición privilegiada que ocupa el prólogo, como vía de entrada en la recepción del ensayo de Valcárcel) opera como un "prisma deformante" (tal como lo define Bourdieu, 1999: 166), que aspira a resignificar las connotaciones de peligrosidad y amenaza, de reemergencia de la "barbarie" bajo la forma de un movimiento de clase, atribuido por Valcárcel a un eventual proceso de radicalización popular. Al postular

\footnotetext{
${ }^{82}$ Mariátegui ([1928] 1994: 17).
} 
que Tempestad en los Andes contiene los mitos que contribuyen a la lucha revolucionaria indígena, y al mismo tiempo atribuirle a su autor el carácter de un "creyente" en ese proceso, Mariátegui logra pasar por alto las ambigüedades semánticas, e incluso las connotaciones negativas implícitas en el texto, para instalar el ensayo de lleno en el espacio de la utopía revolucionaria. De ese modo, modifica la significación telúrica residual de la figuración de la "tempestad", para dotarla de un sentido emergente que viene a ratificar la inminencia -y la necesidad- de un cambio social profundo.

La preocupación por la construcción de ideales y mitos sociales es uno de los principales aspectos del carácter "heterodoxo" del marxismo mariateguiano. El autor de los Siete ensayos... piensa que estos elementos deben arraigar en el "espíritu" y la fantasía (no necesariamente en la conciencia) de los lectores, conformando imágenes claras, capaces de funcionar como ideas fuerza generadoras de acción, a fin de desencadenar un estado anárquico capaz de hacer predominar lo inverosímil en el todo social, hasta lograr subvertir el orden real existente (Beigel, 2003: 102). La apertura de Mariátegui al reconocimiento de la potencialidad del mito (y con él, de la religiosidad popular) se articula con su valoración de la dimensión estética y psicoanalítica de la acción revolucionaria, gracias a su apertura a las vanguardias estéticas y al psicoanálisis freudiano, en tensión con la ortodoxia marxista de la IIIra. Internacional (Beigel, 2003: 102; Terán, 1986: 106). En efecto, estos elementos heterodoxos y espiritualizantes, presentes en el pensamiento de Mariátegui, determinan el rechazo del modelo marxista basado en una "razón cientificista", y apuntalan en cambio su "hincapié marxista en una 'conciencia práctica' inherente y constitutiva" (Williams, 1980: 120). Esta nueva conciencia puede ser definida como una "estructura del sentir" en términos de Williams (1980): para este autor, “aunque son emergentes o preemergentes [las estructuras del sentir] no necesitan esperar una definición, una clasificación o una racionalización antes de ejercer presiones palpables y de establecer límites efectivos sobre la experiencia y sobre la acción" (Williams, 1980: 156). Podemos pensar entonces que el dispositivo ideológico instalado en el "Prólogo" a Tempestad en los Andes le permite a Mariátegui anular la negatividad devaluadora de lo indígena, contenida en las representaciones del ensayo de Valcárcel, para - una vez resignificadas en clave voluntarista- capitalizarlas como un acervo de imágenes míticas "que mueva a los hombres [hacia la revolución social]" (Mariátegui [1925] 1994: 497).

Junto con el desarrollo de esa operación de apropiación, Mariátegui interviene sobre las ambigüedades del texto, resolviéndolas. En este sentido, ejerce una pedagogía teórica sobre el lector ${ }^{83}$ Por ejemplo, si Valcárcel insinúa una lectura materialista del problema del 
indio, pero reencontrando luego que el verdadero problema social son los propios sujetos indígenas, Mariátegui en cambio aclara que

...la reivindicación indígena carece de concreción histórica mientras se mantiene en un plano filosófico o cultural. Para adquirirla - esto es, para adquirir realidad, corporeidad- necesita convertirse en reivindicación económica y política. El socialismo nos ha enseñado a plantear el problema indígena en nuevos términos. Hemos dejado de considerarlo abstractamente como problema étnico o moral para reconocerlo concretamente como problema social, económico y político. Y entonces lo hemos sentido por primera vez esclarecido y demarcado (Mariátegui [1927] 1970: 11).

Del mismo modo, cuando por momentos Valcárcel reactualiza una mirada re-esencializadora de la alteridad social y de la nación, en la que gravitan con fuerza elementos de un racialismo residual pero activo, el prologuista vuelve a reafirmar la perspectiva materialista:

Los que no han roto todavía el cerco de su educación liberal burguesa, y, colocándose en una posición abstractista y literaria, se entretienen en barajar los aspectos raciales del problema, olvidan que la política y, por tanto, la economía, lo dominan fundamentalmente (Mariátegui [1927] 1970: 11).

Mariátegui interviene también en los silencios de ensayo. Por ejemplo, discrepa con respecto a la confianza que muestra Valcárcel en las instituciones educativas adventistas, por considerar que éstas pueden ser "avanzadas del imperialismo anglosajón"; de ese modo, introduce un tópico ausente en Tempestad en los Andes (la cuestión del imperialismo), cardinal en su forma de interpretar la realidad nacional (Mariátegui [1927] 1970: 9-10).

Finalmente, si en Tempestad en los Andes el rol de los intelectuales indigenistas se delinea sobre la necesidad de "encauzar" la potencial activación indígena, "sin perder la ruta en el laberinto de las ideologías", para que no se "desborde" en una posible acción revolucionaria de clase, Mariátegui advierte que la "liquidación del gamonalismo, o de la feudalidad" no puede realizarse "dentro de los principios liberales y capitalistas" que "están en crisis en el mundo", y que ésta no es "una empresa típica y específicamente liberal y burguesa" pues "el pensamiento revolucionario, y aún el reformista, no puede ser ya liberal sino socialista" (Mariátegui [1927] 1970: 13-14).

\footnotetext{
${ }^{83}$ Un movimiento semejante, de resemantización en un sentido radical de la producción ideológica de Spengler, por parte de Mariátegui, es señalado por Mailhe (2020) al considerar la torsión de Mariátegui por imprimir un perfil socialista en la interpretación de La decadencia de Occidente (1923) para anular las diferencias entre ambos modelos teóricos y yuxtaponer el enfoque socialista por encima del relativismo spengleriano.
} 
Las operaciones interpretativas desplegadas por Mariátegui, sobre la literatura y el ensayo peruanos de los años veinte, parecen ser eficaces, pues tienden a obturar el reconocimiento posterior de las ambivalencias y contradicciones ideológicas implícitas en y entre esos discursos, por parte de la crítica. Al mismo tiempo, tiene lugar una cierta invisibilización de las prácticas de apropiación y resignificación llevadas a cabo por el propio autor de los Siete ensayos... Además, la praxis editorialista de Mariátegui, llevada adelante bajo una "política de inclusión" de discursos muy diversos, reenmarcados en su proyecto político cultural, también parece contribuir a la naturalización de ese efecto homogeneizador por parte de la crítica.

Del mismo modo, la conjunción entre marxismo e indigenismo ha sido frecuentemente considerada por la crítica como un mero dato histórico, no como una construcción ideológica. Algunas interpretaciones extienden la radicalidad del cariz marxista del pensamiento de Mariátegui a García y Castro Pozo, pero sobre todo a Valcárcel, llegando a atribuirle un carácter leninista. Esa homogeneización tiende a posponer un análisis más atento que permita percibir las diferentes modulaciones epistemológicas, políticas e ideológicas en su obra, recuperando tanto sus ambivalencias como sus aspectos residuales, y que, simultáneamente, pueda analizar las prácticas específicas llevadas a cabo por Mariátegui para lograr el efecto de cohesión que perdurará luego, y que hemos intentado problematizar.

Tal vez los equívocos interpretativos aquí considerados se relacionen con un abordaje parcial de la historia intelectual, que prescinde de analizar minuciosamente las representaciones, privilegiando en cambio las prácticas de sociabilidad intelectual, o que -por el contrario- se centra en el análisis de algunas fuentes aisladamente, olvidando articular discursos y prácticas intelectuales, u omitiendo cruzar el discurso social con la ideología implícita en los discursos. Este tipo de visiones parciales resultan problemáticas especialmente cuando se abordan sujetos cuya función es precisamente producir bienes simbólicos y significaciones imaginarias de la realidad social (Bourdieu, 1999; Altamirano, 2005).

En esta dirección, creemos que no es posible comprender el indigenismo peruano de los años veinte, en toda su complejidad, si no se apela a la articulación de dos perspectivas teóricas frecuentemente enfrentadas en el campo académico local: la historia intelectual capaz de analizar los discursos y las representaciones sociales en un contexto histórico particular 
(valiéndose de las herramientas que le proveen el análisis del discurso y la sociología de la cultura, para no descuidar - tal como sugieren Altamirano (2005) y Angenot (2010)- el sentido de la forma), y la historia intelectual vinculada a la sociología de los intelectuales (capaz de reconstruir las trayectorias, las redes, la formación académica y las pertenencias políticas e institucionales de esos sujetos, insertándolos en un campo relacional de posiciones).

Como veremos en las conclusiones de esta tesis, para el caso del indigenismo peruano, recuperar las representaciones de la alteridad social, contenidas en las diversas fuentes del indigenismo, es una forma privilegiada de iluminar tanto el carácter polémico de las posiciones epistemológicas, políticas e ideológicas de esos intelectuales, como las tensiones -y las torsiones- operadas por Mariátegui, en el seno de lo que la historiografía posterior consagrará como la formación intelectual indigenista peruana. 


\section{Proximidades y diferencias en los discursos: cuatro modulaciones alternativas del indigenismo peruano}

El análisis de las representaciones de la alteridad social, en los ensayos abordados, nos permite reconocer la heterogeneidad de enunciaciones al interior del discurso indigenista peruano entre 1924 y 1930. En todas ellas, el discurso indigenista se articula con otros discursos diversos en términos epistemológicos, políticos e ideológicos, configurando un mapa complejo de posiciones en torno a los imaginarios indigenistas de modernización nacional y al lugar ocupado por el indígena en esos proyectos de reconfiguración de la nación.

Para comenzar, podemos señalar algunas diferencias entre Tempestad..., El nuеvo indio, Nuestra comunidad indígena y Siete ensayos...., en la construcción formal de los textos, en los paradigmas representacionales a los que adscriben y en el tipo de lectorado al que buscan interpelar. Al acercarse a la retórica vanguardista -hecho visible en la forma de manifiesto que toma el ensayo de Valcárcel y en los recursos formales vanguardistas a los que apela Mariátegui-, Tempestad... y Siete ensayos parecen dirigirse a un lectorado de reciente emergencia, formado en las lecturas de la nueva tradición de las vanguardias europeas y latinoamericanas, que será contemporáneamente interpelado por revistas indigenistas de vanguardia tales como Amauta, La Sierra o Boletín Titikaka. Es posible pensar que esa es una de las razones de la rápida recepción de Tempestad... y de Siete ensayos... en el campo intelectual nacional (sin soslayar el impulso que sin dudas le da a Tempestad... el hecho de ser recepcionado por Mariátegui desde Lima, y publicado por su editorial Amauta). En cambio, El nuevo indio presenta más similitudes en su construcción con respecto al ensayo espiritualista del modernismo (bajo modelos como el de Eurindia de Rojas), lo que presupone un lectorado más tradicional. En contraste con los casos anteriores, y en sintonía con su destinatario estatal, el ensayo de Castro Pozo por momentos parece un informe burocrático, adoptando en algunos tramos una enunciación etnográfica, o incluso reponiendo el tono propio del folclorismo positivista de entresiglos. 
Con respecto a las connotaciones asignadas a la alteridad indígena del pasado, Valcárcel despliega en Tempestad... una concepción positiva del inca "imperial” en el pasado, al igual que García y Mariátegui, mientras que Castro Pozo valora lo indígena preincaico. Por su parte, Valcárcel y Mariátegui se muestran reacios a toda valoración positiva de la Colonia, mientras que García -y menos explícitamente Castro Pozo- la toman como modelo de orden exitoso en lo económico, en lo social y en lo cultural. En relación a estas representaciones del pasado indígena, los intelectuales realizan operaciones identitarias, con efectos en los programas que proponen los ensayos. Valcárcel adhiere al canon de la alta cultura local, al acercarse al incaísmo de la elite regional y estatal; Mariátegui lo hace en base a la consideración del valor estético de lo indígena incaico para la construcción de un imaginario nacional con estatus civilizatorio; Castro Pozo propone un modelo preincaico, también culturalmente distinguido, vinculado a la narrativa sobre el origen de las culturas indígenas en la zona costera, mientras que lo incaico es rechazado por considerarlo una formación social de carácter autoritario y represivo; por el contrario, García descarta lo incaico para apelar a los sectores populares del presente de enunciación como eje de la representación nacional.

Con respecto a las concepciones de la alteridad indígena, Nuestra comunidad Indígena y Siete ensayos... construyen representaciones positivas del indígena del presente; en menor medida ocurre lo mismo en Tempestad..., especialmente cuando se retrata al indígena de las comunidades remotas. Esa resemantización positiva, que rompe con la mirada racialista, es realizada en los tres ensayos en torno a la valoración de la cultura del trabajo comunitario indígena, cuyo origen se ubica desde antes de la presencia europea, en la tradición originaria.

No obstante, Valcárcel y Castro Pozo, cuando abordan al indígena en ámbitos modernos urbanos o suburbanos, invierten la carga semántica de lo indígerna, para mostrarlo como un sujeto regresivo o atávico, cercano al orden de la naturaleza, y por ello peligroso, a tal punto que se lo termina recortando como "el problema nacional", que en el ensayo de Valcárcel es definido como la posibilidad de su activación violenta, en convergencia con su auto-organización como clase y como etnia. Y si retóricamente Valcárcel prescribe el resurgimiento de la cultura inca como catalizador de la redención del indígena, la solución que propone el ensayo pasa por su integración subalternizada a la sociedad nacional, como fuerza de trabajo asalariada, de modo similar a lo que plantea Castro Pozo, aunque este último propone la organización del trabajo indígena en cooperativas, y Mariátegui como fuerza de trabajo para el nuevo modo de producción a instaurar en los latifundios, una vez 
nacionalizados por la reforma agraria. Por el contrario, El nuevo indio despliega una mirada netamente negativa sobre el indígena del presente que permanece ajeno al mestizaje y/o que habita en las comunidades, y en consecuencia proyecta una mirada crítica sobre el ayllu. El indígena y la comunidad son concebidos como reacios al mestizaje, lo que los convierte en un lastre para la modernización que comporta ese proceso de mezcla espiritual. En consecuencia, García responsabiliza a los indígenas por su propia subalternidad, evidenciando en su análisis un olvido de la dominación social, frecuente en las perspectivas culturalistas.

Más allá de sus diferencias, Tempestad..., El nuevo indio y Nuestra comunidad indígena coinciden en el gesto anti-indígena implícito en el distanciamiento y la negativización de la alteridad indígena en el presente, argumento afín a los regionalismos elitistas de los años veinte. Ante la percepción del otro como un peligro y/o como un problema, Valcárcel, García y Castro Pozo prescriben soluciones que van desde la exclusión social y cultural, la integración subalternizada, la depuración de los elementos premodernos, hasta el borramiento de su tradición cultural bajo una nueva identidad nacional/regional (incaísta en Valcárcel, mestiza en García y "neoperuana" en Castro Pozo). Mariátegui pondera al indígena del presente como eje de la reconfiguración nacional, pero bajo una mirada que no logra trascender una imagen sintética, totalizadora, de la diversidad del mundo indígena. Mariátegui parece además no lograr visualizar al indígena fuera de la comunidad. Además, tiene dificultades para representar la alteridad indígena, ya que la mirada distante -y mediada por la literatura- se traduce en una baja densidad semántica en el abordaje del mundo indígena, reducido a unos pocos trazos. En consecuencia, todos los ensayos aquí analizados intentan una explícita ruptura con el racialismo, aunque -tal como vimos a lo largo de este trabajo- lo logran sólo parcialmente, ya que no pueden -o no quieren- evitar recaer en esa perspectiva, al abordar al indígena fuera del ayllu en los casos de Valcárcel, García y Castro Pozo; o al considerar a la alteridad afro y asiática, en el caso de Mariátegui. Las continuidades con esa matriz de pensamiento parecen estar ancladas en la propia lógica del discurso indigenista, pues indigenistas e indígenas no comparten jamás rasgos identitarios en tanto actores sociales, y al indígena le cabe un rol heterónomo -tácitamente- legitimado en una consideración disminuyente de la alteridad, lo que habilita la intervención de los intelectuales.

Las representaciones del mestizo y el mestizaje presentes en los cuatro ensayos terminan proponiendo - con más o menos énfasis- el mestizaje cultural como base para la reconfiguración de la identidad nacional. García y Castro Pozo parecen además valorar 
positivamente la existencia de un mestizaje social. En algunas áreas del discurso de Valcárcel se propone crear una nueva cultura mestiza apela al "inkario" como corpus y Mariátegui avanza en un sentido similar en la valoración cultural de lo indígena como mezcla que debe ser operada desde la literatura. García recurre a una cultura folclórica de base colonial, considerada como ya amestizada, y que, a su criterio, aún persiste en lo subalterno del presente de enunciación (es decir, en lo "lo popular", en los propios términos del ensayo); en esto se asemeja a Castro Pozo, que postula el baile popular como elemento de expresión y vehiculización de la mezcla.

En lo que concierne a la consideración del mestizo y lo subalterno mestizo, García y Castro Pozo valoran ambos términos, convertidos en ejes del nuevo proyecto nacional, en términos de sujeto, ámbito y/o cantera intelectual de la reconfiguración nacional. De modo ambiguo, Valcárcel construye representaciones en extremo negativas del mestizo, aunque paradójicamente propondrá, en otras áreas de su ensayo, un mestizaje nacional sobre los valores culturales de Cusco. Por su parte, Mariátegui valora positivamente el mestizaje cultural, pero rechaza la mezcla social de los años veinte, en base a consideraciones sobre el peso de los elementos afro y asiáticos, análisis en los que hace re-emerger los ideologemas más devaluadores de esas alteridades, desde un análisis que marca fuertes elementos de continuidad con el racialismo de entresiglos.

Las diferencias en la forma de concebir al mestizo convergen en un mismo gesto cuando observamos que, para todos, en mayor o menor medida, la mezcla es siempre una combinación de lo indígena y lo occidental, donde lo indígena se disuelve en una mera pincelada de color local, tema o motivo nacional, para defender la existencia de una inflexión local en el seno del sustrato occidental y modernizador dominante. En ese sentido, siguiendo a Svampa (2016), el efecto homogeneizador que se ejerce sobre la alteridad parece ser un dato central del discurso indigenista, porque tiende a obturar la diversidad como resultado de una voluntad integracionista.

Las dificultades para representar la diversidad de lo indígena del presente, como la diversidad de la mezcla en los proyectos de mestizaje, y la voluntad de crear una nueva identidad cultural "desde arriba", prolongan en el indigenismo el gesto de borramiento de la alteridad indígena que observamos en intelectuales de la generación del novecientos como Francisco García Calderón y José de la Riva Agüero.

Tempestad en los Andes y El nuevo indio presentan muchos puntos de contacto, atribuibles a su condición de discursos orgánicos del regionalismo anticentralista de Cusco; 
Nuestra comunidad indigena contiene, en ese sentido, marcas de un regionalismo cultural costeño (al considerar el aporte antropológico y estético de la cultura chavín). No obstante, es importante aclarar que Tempestad en los Andes y El nuevo indio incluyen, más allá de las similitudes, dos modulaciones alternativas de ese mismo discurso regionalista que amplifica la demanda política de mayor participación de las elites regionales frente a la elite de Lima. Por su parte, Siete ensayos... adhiere a la exaltación de lo serrano como consecuencia de su crítica al centralismo político, no exento de tensiones con la valoración imaginaria de una Lima moderna en torno a los parámetros de la modernización rusa.

En la obra de Valcárcel, las representaciones de la alteridad indígena se combinan con una confianza en la política tradicional -aunque de corte reformista-, tal como se observa solapadamente en el ensayo, y tal como se percibe claramente en su propia trayectoria intelectual. En el ensayo de García, por su parte, se evidencia una desconfianza ante la política tradicional, en su expresión reformista universitaria, combinada con un descrédito de la acción política en general. Más bien, el ensayista deposita su confianza en el arte como modelador de la organización social, que no tiende puentes con ningún movimiento ni organización política de la nueva generación, y menos con la posibilidad de generar alguna organización autónoma de los subalternos indígenas. El rechazo de la política tradicional está también presente en las perspectivas de Castro Pozo y de Mariátegui, pero mientras que en la primera se articula - por su pertenencia estatal- con las disputas de la fracción oligárquica modernizadora de Leguía, contra la fracción oligárquica civilista, en el autor de Siete ensayos... se traduce en un rechazo de la política oligárquica en su totalidad, al atacar su base de sustentación, aunque contradictoriamente ello no implica un rechazo del Estado, al que parece interpelar al enunciar su proyecto de reforma agraria y de constitución de una dirigencia a los fines.

Las modulaciones de los cusqueños y la de Castro Pozo pueden caracterizarse como discursos reformistas moderados (según la definición de Terán, 2010: 208), ligados a la política tradicional reformista en el caso de Valcárcel, a la modernización oligárquica leguiísta en el de Castro Pozo y de carácter apolítico o antipolítico en el caso de García. Mariátegui, por ser el único que cuestiona el régimen oligárquico de propiedad, presenta por el contrario una posición reformista radical. En ese sentido, todos los ensayos proponen una modernización nacional en la que gravita el imaginario modernizador de la Reforma Universitaria como transformación -más o menos profunda- de la configuración social 
oligárquica (en la obra de Mariátegui se evidencia, con más fuerza, el imaginario de la Revolución Mexicana y el de la Revolución Rusa, adquiriendo connotaciones positivas que no presentan ensayos como el de Valcárcel).

Mediadas por las representaciones de la alteridad que cada ensayo presenta, las características de esa modernización son diversas en cada caso. En efecto, Valcárcel insinúa en Tempestad... -a diferencia de García- un proyecto político reformista que se propone suavizar la explotación indígena, para darle a ésta el encuadre propio del trabajo asalariado; es decir, le propone al latifundismo ceder algo para no perderlo todo, y para lograr una mano de obra más eficiente que sea un impulso para la modernización. Castro Pozo y Mariátegui, desde coordenadas políticas diferentes, proponen la integración del indígena en el modelo económico agro-exportador: el primero por medio de la acción cooperativa y el contrato múltiple de trabajo indígenas; el segundo por la nacionalización del latifundio y su apropiación y ejercicio del trabajo comunitario por parte de los indígenas, por el modo de producción organizado en virtud de la tradición comunista indígena que -al igual que Castro Pozo- toma la minga como modelo.

En cambio, la intervención de García permanece exclusivamente en la esfera de la cultura. Sugiere el desarrollo de un capitalismo de base colonial (lo que coincide, no obstante y en parte al menos, con el impulso en favor de la creación de establecimientos productivos, comunales y modernos, en el ensayo de Castro Pozo), ligado a las industrias artesanales y/o al campo del arte. El énfasis en ese tipo de desarrollos autoriza a sospechar que allí se esboza uno de los proyectos más exitosos para Cusco -y para Perú- en el siglo XX: su condición de centro turístico a nivel mundial.

En términos de sociabilidad intelectual, las trayectorias son disímiles. Valcárcel y García participan de los ámbitos tradicionales de la elite de Cusco, aunque sus biografías y trayectorias intelectuales difieren entre sí. Valcárcel combina actividades ligadas a la educación y a la intervención en la esfera pública como intelectual, con prácticas políticas y pertenencias institucionales tradicionales (por su vinculación con el partido Liberal, su participación en el sistema de fraude electoral de la "república aristocrática" y su reingreso a la función estatal de la mano de Sánchez Cerro), aunque desde un posicionamiento ideológico que lo acerca a los sectores reformistas de las oligarquías latinoamericanas de principios de siglo XX (que, de todos modos, no cuestionan el modo oligárquico de dirigir el Estado y la sociedad). Por su parte, García presenta una trayectoria ligada a un ejercicio más "profesional" de la función intelectual, desarrollada principalmente en instituciones 
vinculadas a la Universidad de Cusco. Y si bien toma posición y actúa en favor de un proyecto reformista dentro de dicha institución -en el que despliega críticas a los modelos tradicionales de dirigencia, desde una perspectiva democratizadora en términos sociales-, permanece distante de las fuerzas y movimientos políticos emergentes que, en ese momento, encarnan las críticas más radicales al estado oligárquico. Castro Pozo tiene un importante recorrido estatal, y su condición de funcionario de la Patria Nueva le imprime a su discurso un perfil técnico y una circulación baja en el campo intelectual y en los ámbitos de la nueva generación peruana, al menos hasta la recepción que hace Mariátegui de su obra, en Siete ensayos... Por el contrario, Mariátegui tiene una fuerte presencia en el campo intelectual como promotor de la radicalización de las prácticas intelectuales, dado su recorrido en las áreas editorialistas -diarios y revistas-y en los nuevos espacios políticos de la intelectualidad radicalizada, como lo demuestra su carácter de fundador del primer Partido Socialista y de la Confederación General del Trabajo en Perú.

Llegados a este punto, podemos afirmar que el indigenismo de los años veinte, interpelado por la crisis del régimen oligárquico, se instala como un discurso social hegemónico que funciona como espacio de disputa entre los indigenistas -habilitados para intervenir en las discusiones nacionales, por la centralidad que adquiere el "problema del indio"-, para definir las alternativas a esa crisis, desde posiciones ideológicas diversas.

En Tempestad... y Nuestra comunidad indígena -con las diferencias políticas y de programa ya señaladas-, esas alternativas se presentan como mediaciones, en clave reformista, hacia una recomposición de la hegemonía oligárquica (apelando a la integración controlada de lo subalterno); en El nuevo indio se esboza un guiño hacia una modernización incluyente de los sectores populares del presente, afín a una perspectiva populista, que confía en el arte como elemento integrador; finalmente, en Siete ensayos... se propone romper el orden oligárquico en lo que hace a su base de sustentabilidad -la tierra-, hecho que produciría la integración social y cultural del indígena a la nación.

Ese movimiento de auto-posicionamiento en un lugar dirigente -en la escritura y en la concepción normativa del intelectual- es también ejercido por Mariátegui y por Castro Pozo, aunque en este último articula con la interpelación al Estado leguiísta. En relación a la visión normativa sobre los intelectuales, su función en la resolución de los problemas nacionales y, sobre todo, en su accionar sobre lo subalterno indígena, Tempestad... y El nuevo indio prolongan la pedagogía autoritaria del Ariel, que se combina con una representación 
-también asociada al Modernismo- del intelectual como artista o artesano. Nuestra comunidad indígena y Siete ensayos... prolongan también rasgos elitistas, en base a la consideración de que los intelectuales deben proveer ideales (educativos en el caso de Nuestra comunidad indígena, y sociales en el de Siete ensayos...), para realizar la modernización nacional indigenista. El énfasis que pone Mariátegui en el lugar del ideal abre puntos de contacto con los demás ensayos, produciendo una interpelación para la radicalización del indigenismo, de modo que abarque la crítica de la propiedad latifundista de la tierra.

Gracias al análisis del discurso llevado a cabo en esta tesis, es posible afirmar que, aunque en grados diversos, todos los ensayos presentan continuidades con concepciones elitistas y paternalistas de acción sobre lo subalterno. La sugerida confianza de Mariátegui en una posible organización autónoma de los indígenas -limitada en Castro Pozo a la creación de unidades productivas comunitarias- es débil frente al rol dirigencial del intelectual extendido entre todos los discursos. Posiblemente sea ésta la razón del desencuentro entre indigenismo e indianismo, parafraseando la consideración de García Linera (2008) sobre el desencuentro entre indianismo y marxismo, visible en lo abstracto de la representación del indígena en Siete ensayos... Las representaciones de los incas acompañan estas consideraciones sobre el rol del intelectual, donde el modelo de dirigencia inca se articula con el imaginado para los indigenistas, excepto en el ensayo de Castro Pozo, donde la dirigencia es atribuida al Estado moderno. Tal es así que todos los autores se recortan a sí mismos, en sus discursos, como potenciales dirigentes de los proyectos que enuncian, evidenciando una dimensión personalista de la tarea intelectual, que parece atravesar tanto las prácticas políticas tradicionales como la emergente crítica materialista de Mariátegui. Esa autoreferencialidad de los indigenistas en sus ensayos, posibilitada por el hiato entre indigenismo e indigenidad, genera una obturación de la diversidad sobre el colectivo indígena, impidiendo la emergencia de regímenes de visibilidad y de autopercepción pluriculturales y multiculturales, dinamizadores de las construcciones de las identidades populares indígenas del indianismo (García Linera: 2006).

Paradójicamente, esa reducción de la diferencia indígena ha sido acompañada por la obturación de la diferencia entre los indigenistas, tanto por la inicial recepción de Mariátegui, como por las lecturas historiográficas predominantes desde su muerte. Así, el reconocimiento de la distancia epistemológica, política e ideológica que separa estos discursos entre sí, y respecto de la perspectiva materialista histórica y reformista radical de Siete ensayos..., 
parece haber sido obturado por las operaciones interpretativas desplegadas por el propio Mariátegui para conectar indigenismo y marxismo, en el marco de la invención de la formación intelectual indigenista durante los años veinte.

Para finalizar, creemos que esta tesis constituye un aporte para el reconocimiento de las operaciones (usos, apropiaciones, resignificaciones de otros discursos sociales) y las apuestas ideológicas desplegadas por los intelectuales en sus discursos, a la hora de representar lo popular. Asimismo colabora en el conocimiento de la relación entre las representaciones de la alteridad y su vínculo con a) las representaciones del orden social, sus diagnósticos y propuestas, b) la concepción de la práctica y el rol normativo del intelectual y las relaciones que los intelectuales construyen simbólicamente con los sectores populares, y c) en las estrategias mediante las cuales los intelectuales conforman tradiciones y movilizan actores en su interpelaciones al campo de poder, como aspectos de su intervención discursiva en un contexto social específico.

En particular, este trabajo contribuye a ampliar el reconocimiento de la multiplicidad de concepciones de la alteridad indígena que allí se despliegan y la consecuente heterogeneidad de enunciaciones, al interior del discurso indigenista peruano de los años veinte, así como la diversidad de coordenadas teóricas, políticas e ideológicas contenidas en el mismo, que abren un abanico de posicionamientos iluminando los diversos diagnósticos y propuestas relativos al orden social, la manera en que conciben la práctica intelectual, y las estrategias discursivas y prácticas desplegadas para lograr adhesiones y para concretar esos proyectos de reconfiguración de la sociedad.

\section{Bibliografía}

\section{Fuentes primarias}

AA.VV. ([1927] 1975) La polémica del indigenismo. Lima, Mosca Verde 
AA:VV. (2009). Cusco-Buenos Aires. Ruta de intelectualidad americana (1900-1950). Lima, USMP.

Amauta. Revista mensual de doctrina, literatura, arte, polémica, Director: José Carlos Mariátegui, No 1-32, 1926-1930, edición en facsímil, Lima, Empresa Editora Amauta, 1979.

Diario El Sol de Cusco (1917-1930)

Castro Pozo, Hildebrando ([1924] 1979) Nuestra comunidad indígena. Lima, S/E.

García Calderón, Francisco ([1912] 1979). Las democracias latinas de América/La creación de un continente, Caracas, Biblioteca Ayacucho.

García, José Uriel ([1930] 1937). El nuevo indio, Cuzco, H.G. Rozas.

González Prada, Manuel ([1905] 1964). "Nuestros indios” en Horas de lucha, Lima, Fondo de cultura popular.

Mariátegui, José Carlos ([1928] 1979). Siete ensayos de interpretación de la realidad peruana, Caracas, Biblioteca Ayacucho.

------- ([1927] 1970) "Prólogo" a Valcárcel, Luis. Tempestad en los Andes. Lima, Populibros Peruanos.

([1928] 1994). Siete ensayos de interpretación de la realidad peruana, en Mariátegui total, Lima, Empresa Editora Amauta.

([1928] 2011). Siete ensayos de interpretación de la realidad peruana. Lima, Ministerio de Cultura. Edición facsimilar.

López Albujar, Enrique ([1920] 1950). Cuentos Andinos, Lima, Mejía Baca.

Riva Aguero, José ([1905] 1962). Carácter de la Literatura del Perú independiente, Lima, Pontificia Universidad Católica del Perú.

Rodó, José E. ([1900] 1932). Ariel. Montevideo, Claudio García y Cía. 
Valcárcel, Luis E. (1925). Del Ayllú al Imperio, Lima, Garcilaso.

([1927] 1970). Tempestad en los Andes. Lima, Populibros Peruanos.

(1981). Memorias, Lima, Instituto de Estudios Peruanos.

\section{Fuentes secundarias}

AA.VV. (2008). "Legados de Ernesto Quesada" en Políticas de la memoria, Buenos Aires, CEDINCI.

Abu-Lughod, Lila (2005). "La interpretación de las culturas después de la televisión" en Etnografías contemporáneas, número 1.

Achugar, Hugo (1994). "La hora americana o el discurso americanista de entreguerras" en Pizarro, Ana (comp.) América Latina: palabra, literatura e cultura, San Pablo, UNICAMP.

Altamirano, Carlos (2002). "Intelectuales" en Términos críticos de sociología de la cultura, Buenos Aires, Paidós.

-------- (2005). Para un programa de historia intelectual, Buenos Aires, Siglo XXI.

Angenot, Marc (2010). El discurso social, Buenos Aires, Siglo XXI.

Ansaldi, Waldo (2006). Calidoscopio latinoamericano: imágenes históricas para un debate vigente, Buenos Aires, Ariel.

Añón, Valeria (2013). "De México a Cuzco: nostalgia, memoria y usos del pasado en crónicas de tradición indígena”, Vanderbilt e-journal of Luso-Hispanic studies; vol. 9

Aricó, José, comp. (1980) "Introducción" a Mariátegui y los orígenes del marxismo latinoamericano, México, Cuadernos de Pasado y Presente.

Avanza, Martina (2005) “¿Qué significa ser cusqueño? La contrucción de un discurso identitario en un diario de Cuzco entre 1919 y 1930", en Molinié, Antoinette (comp.), Etnografías de Cuzco. Cuzco, Entro de estudios regionales andinos Bartolomé de las Casas. 
Bajtín, M. (1992). Estética de la creación verbal, México, Siglo XXI.

Barthes, Roland, (1999). S/Z, México, Siglo XXI.

Beigel, Fernanda (2003). El itinerario y la brújula. El proyecto estético-politico de José Carlos Mariátegui, Buenos Aires, Biblos.

(2006). La epopeya de una generación y una época. Las redes editoriales de José Carlos Mariátegui en América Latina, Buenos Aires, Biblos.

Bergel, Martín (2010). "La desmesura revolucionaria. Prácticas intelectuales y cultura vitalista en los orígenes del APRA peruano (1921-1930)", en Altamirano, Carlos (dir.) Historia de los intelectuales en América Latina, TII, Buenos Aires, Katz.

Bergel, Martín (2019). La desmesura revolucionaria. Cultura y politica en los orígenes del $A P R A$, Buenos Aires, La Siniestra.

Bernand, Carmen (2001). "Mestizos, mulatos y ladinos en Hispanoamérica: un enfoque antropológico de un proceso histórico" en León Portilla, Miguel (coord.) Motivos de la antropología americanista, México, FCE.

Bobbio, Norberto et. al., (1995). Diccionario de política, México, FCE.

Botana, Natalio (1985). El orden conservador. La política argentina entre 1880 y 1916. Buenos Aires, Sudamericana.

Bourdieu, Pierre (1983). Campo de poder y campo intelectual, Buenos Aires, Folios.

--------- (1988). Cosas dichas, Buenos Aires, Gedisa.

(1999). "La circulación internacional de las ideas" en Intelectuales, política y poder, Buenos Aires, Eudeba.

Cagni, Horacio (s/f). "Miradas cruzadas: Spengler en Iberoamérica”, mimeo.

Campuzano Arteta, Álvaro (2017). La modernidad imaginada. Arte y literatura en el pensamiento de José Carlos Mariátegui (1910-1930), Iberoamericana, Madrid. 
Castilla, Martín (2010). Concepciones de la alteridad social en el indigenismo peruano de los años veinte, La Plata, Memoria Académica de la Facultad de Humanidades y Ciencias de la Educación - UNLP.

(2011). "Un indigenismo contradictorio. Luis Valcárcel y Tempestad en los Andes" en Mailhe, Alejandra (comp.). Pensar al otro/ pensar la nación, La Plata, Al Margen.

(2012). "Mariátegui ante la muerte de Ingenieros: apropiación simbólica y construcción de un paradigma intelectual" en Políticas de la Memoria, Buenos Aires, CeDInCI, número 13.

--------- (2013). “José Carlos Mariátegui: apropiaciones de la literatura y el ensayo en la construcción de una tradición intelectual” en Orbis Tertius, La Plata, UNLP.

Chartier, Roger (1995). El mundo como representación. Historia cultural: entre prácticas y representación, Barcelona, Gedisa.

Clifford, James (1995). Dilemas de la cultura, Barcelona, Gedisa.

De Certeau, Michel (1999). La cultura en plural, Buenos Aires, Nueva Visión.

De la Cadena, Marisol (2007). Formaciones de indianidad. Articulaciones raciales, mestizaje y nación en América Latina, Popopayán, Envión.

De la Peña, Guillermo (2006). "Nacionales y extranjeros en la historia de la antropología mexicana" en Rutsch, Metchild (comp.). La historia de la antropología en México, México, Plaza y Valdés.

Deustua, José y Rénique, José Luis (1984). Indigenismo y descentralismo en el Perú, 18971931, Cusco, Centro de Estudios Rurales y Andinos Bartolomé de las Casas.

Favre, Henri (1998). El indigenismo, México, FCE.

Fell, Eve Marie (1194). "Primeras reformulaciones: del pensamiento racisra al despertar de la conciencia revolucionaria" en Pizarro, ana (comp.). América Latina: Palabra, Literatura e Cultura, San Pablo, unicamp, vol. I.

Foucault, Michel (1970). La arqueología del saber, México, Siglo XXI. 
Funes, Patricia (2006). Salvar la nación, Buenos Aires, Prometeo.

Gamio, Manuel (1916). Forjando Patria

García Linera, Álvaro (2008). La potencia plebeya. Acción colectiva e identidades indígenas obreras y populares en Bolivia. Buenos Aires, Prometeo.

Gil Lázaro, Alicia (2004). "Las señas de identidad de un escritor ausente: América Latina y Perú en el pensamiento de Francisco García Calderón", en Granados, Aimer y Marichal, Carlos (comps.). Construcción de las identidades latinoamericanas. Ensayos de historia intelectual. Siglos XIX y XX, México, El Colegio de México.

Gonzáles, Osmar (1996). Sanchos fracasados. Los arielistas y el pensamiento político peruano, Lima, Preal.

--------- (2010). “Indigenismo, nación y política en el Perú (1904-1930)” en Altamirano, Carlos. Historia de los intelectuales en América Latina, Buenos Aires, Katz.

González Echevarría, R. (2001). "El extraño caso de la estatua parlante: Ariel y la retórica magisterial del ensayo latinoamericano" en La voz de los maestros, Madrid, Verbum.

Gorelik, Adrián (2001). "Mapas de identidad. La imaginación territorial en el ensayo de interpretación nacional: de Ezequiel Martínez Estrada a Bernardo Canal Feijóo" en Prismas. Revista de historia intelectual, Bernal, Universidad Nacional de Quilmes, $\mathrm{n}^{\circ} 5$.

Gramsci, Antonio (1972a). Cultura y literatura, Barcelona, Península.

Visión.

(1972b). Los intelectuales y la organización de la cultura, Buenos Aires, Nueva ([1929-1932] 2011) Quaderni del carcere, Roma, Einaudi.

Grimson, Alejandro (2011). Los límites de la cultura. Buenos Aires, SXXI.

Grimson, Alejandro y Semán, Pablo (2005). “Presentación” en Etnografías contemporáneas, número 1.

Gruzinski, Serge (2000). El pensamiento mestizo, Barcelona, Paidós. 
Hale Charles (1991). "Ideas políticas y sociales en américa Latina, 1870-1930” en Bethell, Leslie, ed. Historia de América Latina, Barcelona, Crítica, vol. VIII.

Klarén, Peter (1991). "Los orígenes del Perú moderno, 1880-1930” en Bethell, Leslie, ed. Historia de América Latina, Barcelona, Crítica, vol. X

(2004). Nación y sociedad en la historia del Perú, Lima, IEP.

Kohan, Néstor (2000). De Ingenieros al Che, Buenos Aires, Biblos.

Kourí, Emilio (2010). "Manuel Gamio y el indigenismo de la Revolución Mexicana", en Altamirano, Carlos (dir.) Historia de los intelectuales en América Latina, TII, Buenos Aires, Katz.

Laclau, Ernesto (2005). La razón populista, Buenos Aires, FCE.

Lagos, Felipe (2010). "Los Siete ensayos de Mariátegui como crítica de la razón oligárquica" en Weimberg, Liliana. Estrategias del pensar, México, CIALC-UNAM.

Laplatine, François - Alexis Nouss (2007). Mestizajes. De Archimboldo a Zombi. Buenos Aires, FCE.

Lauer (1998). Andes imaginarios. Discursos del indigenismo-2. Cusco-Lima, Centro de Estudios Regionales Andinos Bartolomé de Las Casas-Sur.

Löwy (2000). La estrella de la mañana: surrealismo y marxismo. Buenos Aires, El cielo por asalto.

Mailhe, Alejandra (2004). “¿Hacia una antropofagia del pasado? Continuidades y rupturas en la obra de Oswald de Andrade". Anclajes VIII. 8, pp. 197-239.

(2005). "Epistemologías, oligarquías y escrituras en crisis. Del racialismo al culturalismo en el ensayo latinoamericano de los años treinta" en Anuario de Estudios Americanos 62, 1, pp. 29-53. Sevilla, Escuela de Estudios Hispano-Americanos. ISSN: 0210-5810. 
- (2008). "Hacia una reauratización de la experiencia moderna en José Martí" en IPOTESI. Revista de Estudos de Pós-graduação em Letras da Universidade Federal de Juiz de Fora, Minas Gerais - Brasil. ISSN: 1982-0836; Vol. 12, pp. 51-62.

(2009). “Hacer el desierto. Ensayo y fotografía en la percepción del 'otro' durante la 'Campaña al Desierto' en Representaciones, Córdoba, Universidad Nacional de Córdoba (en prensa)

(2010a). “Es posible conocer al otro? Indagaciones en torno a la relación entre fotografía y ensayo en El México desconocido de Carl Lumholtz" en Soulages, F - S. Solas (comp.). Fotografia y cuerpos políticos, La Plata, Edulp (en prensa).

-- (2010b). Pensar al otro, pensar la nación, La Plata, Al Margen.

(2010c). "Prólogo" al Dossier "Discursos e independencia en América Latina: reflexiones críticas", Revista de Filosofía, La Plata, Universidad Nacional de La Plata, №41.

(2010d). "Imágenes del otro social en Brasil de fin del siglo XIX. Canudos como espejo en ruinas. Prismas vol.14 Nº1 Bernal. Versión On-line ISSN 1666-1508

(2011). Brasil, márgenes imaginarios. Lo popular en la novela y el ensayo del siglo XIX a la vanguardia, Buenos Aires, Lumiere.

(2012). 'La hermenéutica del descenso. El 'viaje arqueológico' hacia el pasado, el inconsciente y la alteridad social. en las obras de Bernardo Canal Feijóo y Arthur Ramos”. VIII Congreso Internacional de Teoría y Crítica Literaria Orbis Tertius. Centro de Estudios de Teoría y Crítica Literaria - IdIHCS/CONICET. Facultad de Humanidades y Ciencias de la Educación. Universidad Nacional de La Plata. ISSN 2250-5741.

- (2013a). "'El laberinto de la soledad' del genio, o las paradojas de El hombre mediocre", Revista Varia Historia; vol. 29, N49. Departamento de Historia. Universidad Nacional de La Plata, pp. 197-216.

(2013b). "Un sociólogo de los intelectuales... a la luz de la sociología de los intelectuales”, Prismas vol.17 N² Bernal. Versión On-line ISSN 1852-0499.

(2013c). "Los bordes de la imagen. Ensayo y fotografía en la percepción del "otro" social (Argentina, Brasil y México)". IX Jornadas de Investigación del Departamento de Filosofía. FaHCE-UNLP. ISSN 2250-4494. 
(2016). "Polémicas ideológicas en la antropología argentina: el americanismo cientificista de la Biblioteca Humanior". IX Jornadas de Sociología de la UNLP. Ensenada. ISSN 2250-8465.

(2017). "Viaje al interior, la cultura popular, el pasado y el inconsciente. Una lectura crítica de la teoría del mestizaje de Ricardo Rojas", Anclajes, UNLPam,

(2019a). "Un confinamiento en los confines: Archipiélago de Ricardo Rojas como americanización del interior". Trabajo y Sociedad. Sociología del trabajo- Estudios culturales- Narrativas sociológicas y literarias. Núcleo Básico de Revistas Científicas Argentinas (Caicyt-Conicet). No33, Vol. XX, Santiago del Estero, Argentina. ISSN 15146871 .

(2019b). "El mestizaje en América Latina durante la primera mitad del Siglo XX”, Antíteses, Londrina, v.13, n. 24

(2021). "El impacto de La decadencia de Occidente de Oswald Spengler en los indigenismos latinoamericanos: el caso de Ernesto Quesada" en prensa en Patricia Arenas Lena Dávila (comps.). Entre la naturaleza y la cultura. Sabios y viajeros alemanes en los orígenes de la antropología argentina, Buenos Aires, CICCUS/CLACSO.

Maingueneau, Dominique (1987). Nouvelles tendences en analyse du discours, París, Hachette.

(2002). "Problemes d'ethos” en Práctiques, nro. 113/114.

Martínez, Ana Teresa (2011). Los hermanos Wagner. Arqueología, campo arqueológico nacional y construcción de la identidad en Santiago del Estero, 1920-1940, Bernal, UNQ.

Majluf, Natalia (1994). "El indigenismo en México y Perú: hacia una visión comparativa" en Arte, historia e identidad en América: visiones comparativas, tomo II, México, UNAM.

Mangone, Carlos - Jorge Warley (1992). El manifiesto. Un género entre el arte y la política, Buenos Aires, Biblos.

Marzal, Manuel, (1998). Historia de la antropología indigenista: México y Perú, México, Universidad Autónoma Metropolitana-Iztapalapa

Ortiz, Renato (1996). Otro territorio. Ensayos sobre el mundo contemporáneo. Buenos Aires, UNQ. 
Ortner, Sherry (2005). "Geertz, subjetividad y conciencia posmoderna"

Paris, Robert (1980). "El marxismo de Mariátegui” en Aricó, José, (comp.) Mariátegui y los orígenes del marxismo latinoamericano", México, Cuadernos de Pasado y Presente.

Paz, Octavio (1982). Sor Juana Inés de la Cruz o las trampas de la fe, México, Seix Barral.

Perazzi, Pablo (2009). "Cartografías corporales: las pesquisas antropológicas del doctor Roberto Lehmann-Nitsche, Buenos Aires: 1897-1908”, Cuadernos de antropología social $\mathrm{n}^{\circ} 29$, Buenos Aires, UBA

Portantiero, Juan Carlos (1978). Estudiantes y política en América Latina, México, Siglo XXI.

Prieto, Mercedes (2004). Liberalismo y temor: imaginando los sujetos indígenas en el Ecuador poscolonial, 1895-1950, Quito, Flacso.

Poole, Deborah (2000). Visión, raza y modernidad. Lima, Sur.

Quesada, Ernesto (1907). "La cuestión obrera y su estudio universitario", Buenos Aires, Menéndez.

(1926). "Spengler en el movimiento intelectual contemporáneo" en revista Humanidades, La Plata, UNLP.

Quijada, Mónica (1996). "Los 'Incas arios': historia, lengua y raza en la construcción nacional hispanoamericana del Siglo XIX", en Revista Histórica, Lima, PUCP.

Quijano, Aníbal (1978). Imperialismo, clases sociales y Estado en el Perú: 1890-1930/ El Perú en la crisis de los años 30, Lima, Mosca Azul.

Política.

(1988). Modernidad, identidad y utopía en América Latina, Lima, Sociedad y

Rama, Angel (1981). "Prólogo" a Arguedas, José María, Formación de una cultura nacional indoamericana, México, Siglo XXI.

(1982). Transculturación narrativa en América Latina, México, Siglo XXI. 
Ramos, Julio (1989). Desencuentros de la modernidad en América Latina. Literatura y política en el siglo XIX, México, FCE.

Rojas, Ricardo [1922](1951). Eurindia, Buenos Aires, Losada.

Rutsch, Metchild (2007). "Franz Boas y la profesionalización de la antropología norteamericana" en Entre el campo y el gabinete. Nacionales y extranjeros en la profesionalización de la antropología mexicana, México, INAH.

Sazbón, José (2002). "Filosofía y revolución en los escritos de Mariátegui" en Historia y representación, Bernal, Universidad de Nacional de Quilmes.

Schwartz, Jorge (2002). Las vanguardias latinoamericanas. Textos programáticos y críticos, México, FCE.

Skinner, Quentin (2000). "Significado y comprensión de la historia de las ideas" en Prismas. Revista de historia intelectual, Bernal, Universidad Nacional de Quilmes, $\mathrm{n}^{\circ} 4$.

Svampa, Maristela (1994). El dilema argentino: civilización o barbarie, Buenos Aires, El cielo por asalto.

--------- (2016). Debates latinoamericanos. Indianismo, desarrollo, dependencia y populismo, Buenos Aires, Edhasa.

Starobinski, J. (1999). La palabra civilización. Prismas - Revista De Historia Intelectual, 3(1)

Stefanoni, Pablo (2015). Los inconformistas del Centenario: intelectuales, socialismo y nación en una Bolivia en crisis (1925-1939), La Paz, Plural.

Tarcus, Horacio (2001). Mariátegui en la Argentina, O las políticas culturales de Samuel Glusberg, El cielo por asalto.--------- (2007). Marx en la Argentina: sus primeros lectores obreros, intelectuales y cientificos. Buenos Aires, SXXI.

Tarcus, Horacio (2007). Marx en la Argentina, Buenos Aires, Siglo XXI.

Terán, Oscar (1986). "Mariátegui: la nación y la razón” en En busca de la ideología argentina, Buenos Aires, Catálogos. 
- (1987) Positivismo y nación en la Argentina, Buenos Aires, Puntosur.

(2008). Historia de las ideas en la Argentina, Buenos Aires, Siglo XXI.

(2008a). “Amauta: vanguardia y revolución” en Prismas, № 12.

(2010). "El Ariel de Rodó o cómo entrar en la modernidad sin perder el alma" en

Weimberg, Liliana. Estrategias del pensar, México, UNAM.

Todorov, Tvetan (1991). Nosotros y los otros, México, Siglo XXI

Ugarte, César (1927). Bosquejo de la historia económica del Perú

Vasconcelos, José (1925). La raza cósmica

Villlaverde Alcalá Galiano, Luis en Aricó, José

Voloshinov, V. y Bajtín, M. (1992), El marxismo y la filosofía del lenguaje, Madrid, Alianza.

Wade, Peter (2000). Raza y etnicidad en Latinoamérica, Quito, Abya Yala.

Weimberg, Liliana (2004). Umbrales del ensayo, México, UNAM.

Williams, Raymond (1980). Marxismo y Literatura, Barcelona, Península.

(2002). La politica del modernismo. Contra los nuevos conformistas. Buenos Aires, Manantial.

Zeballos Aguilar, Ulises Juan (2002). Indigenismo y nación. Los retos a la representación de la subalternidad aymara y quechua en el 'Boletín Titikaka' (1926-1930). Lima, Instituto Francés de Estudios Andinos. 
